\title{
Housing and Social Transition in Japan
}

In the post-war period Japan has experienced radical social and economic transformations, asserting itself as the world's second largest economy by 1968 . Housing and construction have been at the heart of this revitalization, a key socioeconomic policy, and a stabilizing factor during rapid modernization. Housing and Social Transition in Japan explores the nature of the Japanese housing system, focusing on how it has been embedded in wider structures of social and economic change.

While Japan demonstrates many of the characteristics of western housing and social systems, including mass home ownership and consumption-based lifestyles, economic growth and modernization have been achieved in balance with indigenous social values and practices. This book presents a number of perspectives on the Japanese housing system, outlining a comprehensive account of its dynamic role during a period of unprecedented social and economic change.

Leading Japan-based specialists address a range of topical issues, questioning prevailing assumptions formed in western societies concerning the role of housing and dwelling in processes of social change. This book generates an original consideration of the way housing structures and practices have contributed to the evolution of modern Japan and its twenty-first century reorientation.

As well as providing challenges and insights for the academic community at large, this book will also supply a good introduction to the study of Japan and its housing, economic, social and welfare systems generally.

Yosuke Hirayama is Professor of Housing and Urban Studies at Kobe University in Japan. He is the author of several books on housing and urban transformations in Japanese, and has also published widely in international housing and urban research journals. He is a founding member of the Asia-Pacific Network for Housing Research.

Richard Ronald is a Research Fellow at the Research Institute for Housing, Urban and Mobility Studies at Delft University of Technology in the Netherlands, and was formerly a Research Fellow at Kobe University in Japan. He is a former recipient of the Japan Foundation Doctoral Fellowship and the Japan Society for the Promotion of Science Postdoctoral Fellowship. 


\section{Housing and society series}

\section{Edited by Ray Forrest}

School for Policy Studies, University of Bristol

This series aims to situate housing within its wider social, political and economic context at both national and international level; in doing so it will draw on the full range of social science disciplines and on mainstream debate on the nature of contemporary social change. The books are intended to appeal to an international academic audience as well as to practitioners and policymakers - to be theoretically informed and policy relevant.

\section{Housing and Social Transition in Japan}

Edited by Yosuke Hirayama and Richard Ronald

\section{Housing Transformations}

Shaping the space of 21 st century living

Bridget Franklin

\section{Housing and Social Policy}

Contemporary themes and critical perspectives

Edited by Peter Somerville with Nigel Sprigings

\section{Housing and Social Change}

East-West perspectives

Edited by Ray Forrest and James Lee

Urban Poverty, Housing and Social Change in China

Ya Ping Wang

\section{Gentrification in a Global Context}

Edited by Rowland Atkinson and Gary Bridge

Forthcoming:

\section{Sustainable Development}

A new perspective for housing analysis

Rebecca Chiu

\section{Housing, Care and Inheritance}

Intergenerational transfer in Britain and Japan

Misa Izuhara 


\section{Housing and Social Transition in Japan}

Edited by Yosuke Hirayama and Richard Ronald

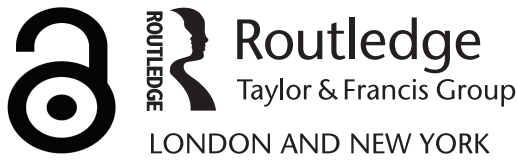


First published 2007 by Routledge

Published 2017 by Routledge

2 Park Square, Milton Park, Abingdon, Oxon OX14 4RN

711 Third Avenue, New York, NY 10017, USA

Routledge is an imprint of the Taylor \& Francis Group, an informa business

Copyright (C) 2007 Yosuke Hirayama and Richard Ronald for selection and editorial matter; individual chapters, the contributors

Typeset in Times and Frutiger by

HWA Text and Data Management, Tunbridge Wells

The Open Access version of this book, available at www.tandfebooks.com, has been made available under a Creative Commons Attribution-Non Commercial-No Derivatives 4.0 license.

British Library Cataloguing in Publication Data

A catalogue record for this book is available from the British Library

Library of Congress Cataloging-in-Publication Data

Housing and social transition in Japan / edited by Yosuke Hirayama and Richard Ronald.

p. cm. - (Housing and society series)

Includes bibliographical references and index.

1. Housing-Japan. 2. Housing policy-Japan. I. Hirayama, Yosuke

II. Ronald, Richard.

HD7367.A3H68 2007

333.33'80952-dc22

2006019796

ISBN13: 978-0-415-38361-5 (hbk)

ISBN13: 978-0-415-65506-4 (pbk) 


\section{Contents}

List of figures

1 Introduction: does the housing system matter?

Yosuke Hirayama and Richard Ronald

2 Reshaping the housing system: home ownership as a catalyst for social transformation

Yosuke Hirayama

3 Transformations in housing construction and finance

Eiji Oizumi

4 Welfare regime theories and the Japanese housing system

Iwao Sato

5 Turning stock into cash flow: strategies using housing assets in an ageing society

Misa Izuhara

6 Housing, family and gender

Mieko Hinokidani

7 Social exclusion and homelessness

Masami Iwata

8 The Japanese home in transition: housing, consumption and modernization

Richard Ronald

9 Situating the Japanese housing system

Richard Ronald and Yosuke Hirayama 


\section{Figures}

2.1 Self ranking of social class in Japan 1958-2004

2.2 Nominal housing prices of homes with GHLC loans within a $70 \mathrm{~km}$ radius of Tokyo city

2.3 Capital loss on typical condominium unit of 70 square metres within a $70 \mathrm{~km}$ radius of Tokyo city

2.4 Outstanding mortgage debt as a percentage of GDP

2.5 Ratio of households with debts on residential property

2.6 Home ownership rate by age

2.7 Household moves and tenure change

2.8 Completions and projected completions of tower condominiums, Tokyo

2.9 Floor area, price per square metre and a price of a unit, Aoyama Park Tower

2.10 Price per square metre, by floor number of condominium units among the 22 case-study tower developments in Tokyo

3.1 Newly advanced housing loans 1989-2004

3.2 Housing construction starts 1968-2004

4.1 Company provision costs related to housing (monthly amount per employee)

4.2 Ratio of number of companies that reduced housing services 1997-2002

4.3 Construction of public housing 1995-2004

5.1 Value of assets per household by age group of household

6.1 Average floor space per dwelling by housing tenure

6.2 The share of households below minimum housing standard by number of household members

6.3 Ratios of employment of women between 1975 and 2000 in Japan

6.4 Distribution of housing tenure, lone-mother families, 2003

7.1 Welfare programmes for the homeless and the number of users in Tokyo 


\section{Tables}

2.1 Housing tenure 19

2.2 Home ownership rate by age cohort between 1988 and $1993 \quad 30$

3.1 Housing construction and 'scrap and build' ratio 57

3.2 Performance of major house-building companies as of March 2003

3.3 Differences in the composition of housing construction between the three metropolitan areas and the other local areas in 2004

3.4 Elimination and concentration of small house-builders 64

4.1 Comparison of housing tenure 77

4.2 Share of construction of social rental housing to total new housing construction

5.1 Estimated value of assets per household by age group of household head

6.1 Selected indicators of women's socio-economic conditions in Japan and EU countries

6.2 Household by family type

7.1 Demographic characteristics of homelessness

7.2 Occupations and employment status prior to homelessness 147

7.3 Type of housing prior to homelessness

7.4 Demographic characteristics of homelessness by homeless type

7.5 Reported period of rough sleeping of shelter residents and street homeless in Tokyo 


\section{Contributors}

Mieko Hinokidani is Associate Professor at the Graduate School of Human Life Sciences at Osaka City University. She specialized in comparative housing policy studies and received her Ph.D. in housing and built environment studies at Osaka City University. She has worked in cross-disciplinary fields in France, Canada and Japan. Her recent articles deal with issues of housing vulnerability from the viewpoint of social exclusion, housing for the elderly, and managerial questions concerning public housing estates in Japan and France. She is a directorate committee member of the Association of Urban Housing Sciences in Japan. She also belonged to the commission of the academy at the City Planning Institute of Japan and the editorial committee on research transactions at the Architectural Institute of Japan.

Yosuke Hirayama is Professor of Housing and Urban Studies at the Faculty of Human Development, Kobe University. He is a specialist in housing and urban change, home ownership and social inequalities, as well as comparative housing policy. His work has appeared in numerous Japanese and international academic journals. He has also received academic prizes from the City Planning Institute of Japan, the Architectural Institute of Japan and Tokyo Institute of Municipal Research. His current research focuses on the differentiation of housing pathways and the restructuring of the urban home ownership system. He is a founding member of the Asia-Pacific Network for Housing Research and chaired its 2005 international conference on Housing and Globalization.

Masami Iwata is Professor of Social Welfare at Japan Women's University in Tokyo and a member of the Social Security Council in the government ministry. She is the foremost researcher in the field of poverty and social exclusion in Japan and has been awarded academic prizes by the Society for the Study of Social Policy and has also been awarded the Professor Fukutake Prize. Her recent work concerns the dynamics of poverty and homelessness policies. Her publications in English include works on Homelessness in 
Contemporary Japan and Commonality of Social Policy on Homelessness: Beyond the Different Appearances of Japanese and English Policies.

Misa Izuhara is a Research Fellow in the School for Policy Studies at the University of Bristol, UK. She has worked extensively in the areas of housing and social change, public policy in ageing society, and comparative social policy related to Japan. She is the author of Family Change and Housing in Post-War Japanese Society and the editor of Comparing Social Policies: Exploring New Perspectives in Britain and Japan. Her recent projects include a series of comparative research studies on care and inheritance funded by the UK Economic and Social Research Council. Misa is also currently the editor of the journal, Policy and Politics.

Eiji Oizumi is Professor of Economic Policy at the Faculty of Economics, Wakayama University. He completed his postgraduate studies in the School of Economics at Hokkaido University, and received his doctorate in economics at Kyoto University. His research interests are urban economy and housing, and the economics of land. He is a member of the Asia-Pacific Network for Housing Research, the Association of Urban Housing Sciences (Japan), the Political Economy and Economic History Society (Japan), and the Japan Housing Council. He has published in English on Property Finance in Japan, and Housing Provision and Marketization in 1980s and 1990s Japan, and more recently on FinancialDeregulation and the Privatization of Housing FinancePolicyinJapan.

Richard Ronald is a Research Fellow at the Research Institute for Housing, Urban and Mobility Studies at Delft University of Technology in the Netherlands, and was a Research Fellow at Kobe University in Japan between 2002 and 2006. He is the former recipient of the Japan Foundation Doctoral Fellowship and the Japan Society for the Promotion of Science Postdoctoral Fellowship. His published work has focused on housing consumption in Britain and Japan as well as housing systems and home ownership across East Asian, European and Anglo-Saxon societies. Richard is a member of the Asia-Pacific Network for Housing Research and was coordinating secretary for its 2005 conference on Housing and Globalization.

Iwao Sato is Professor of Sociology of Law at the Institute of Social Science at the University of Tokyo. His research addresses the comparative study of housing policy and housing law, citizen mobilization and activism in urban development, and the function of judiciary in modern Japan. His first book in the field of housing studies (in Japanese) concerned the comparative study of the development of rent acts in England, Germany and Japan, focusing the interaction of law and policy in welfare states. His publications in English include Judicial Reform in Japan in the 1990s: Increase of the Legal Profession, Reinforcement of Judicial Functions and Expansion of the Rule of Law and Autonomy and Mobilization: Two Faces of Japan's Civil Society. 


\section{Preface}

Few societies have demonstrated such rapid levels of urban and social change as Japan. While the Japanese home and housing system have been at the heart of transformations, their role has been relatively obscured in popular discourses within and beyond Japan. Indeed, there are a preponderance of clichés concerning Japanese housing that swing between images of the traditional Zen house, typified by an elegant simplicity of space and the harmony of the household, to concepts of ultra-modern urban housing and box-like living units. Academic books have tended to focus on housing dimensions in terms of either architecture or economic mechanisms, and have subsequently tended to romanticize the exotic and unusual elements of Japanese dwelling, or reduce it to a quantifiable element within the nexus of the Japanese economic miracle.

The purpose of this volume is to move beyond reductive discourses and engage with Japanese housing in more normalized and comprehensive terms. The authors assembled for this edition work on Japanese housing within a number of arenas ranging from economics, to urban and city planning, to social policy and anthropology. They also constitute a group of local specialists that engage in debates on the role and impact of housing in society, both domestically and internationally, within a field recognized as 'housing studies' within the international literature. Each chapter represents a consideration of the key factors and key issues, normally including original empirical data, relating to the main dimensions of the housing system, from which the reader can begin to consider housing in Japan as a dynamic element within a holistic and comprehensible socio-economic and cultural system.

The idea for this volume began in a number of conversations in our research offices at Kobe University and at Asia-Pacific Network for Housing Research (APNHR) conferences. We were struck by the points raised above, but also, specifically, by the lack of material in English about Japanese housing by Japanese specialists compared to the volume of published material, and interest in Japan, by foreign researchers. We were further concerned with the lack of attention 
housing receives in analyses of structures and processes of change in Japanese society. This edition therefore seeks to fill these gaps and address these concerns by assembling contributions from salient Japanese specialists in a single volume, and by analytically embedding housing and urban dimensions in the consideration of Japan's recent history. As Japan has represented somewhat of an enigma in comparative social, economic and urban research, we also hoped that our analysis would provide a challenge to some of the assumptions that prevail in the research field as a result of the predominance of cases drawn from western contexts which are normally assumed to be universally relevant.

We have a number of acknowledgements to make and thanks to give. First, we must thank Ray Forrest of Bristol University in the UK for helping us crystallize the book project and pursue its inclusion in the Housing and Society series. Second, our appreciation goes to Seita Mori at Kobe University for all his work in editing the graphic materials included in this book. We also would like to thank the editorial staff at Routledge for their patience with us. Institutionally, we also need to acknowledge the support of the Faculty of Human Development at Kobe University, the Japan Foundation and the Japanese Society for the Promotion of Science, who provided research grants and fellowships that made this volume possible. 



\title{
1 Introduction
}

\section{Does the housing system matter?}

\author{
Yosuke Hirayama and Richard Ronald
}

\section{Introduction}

In the post-war period Japan has experienced some of the most radical social and economic transformations of any modern society, from clambering out of the ruins of military defeat in 1945 to asserting itself as the world's second largest economy by 1968 . Housing and construction have been at the heart of the rebuilding and revitalization of the Japanese economy, a key policy in the state's socio-economic agenda, as well as a stabilizing factor in social development during a period of rapid modernization. Housing market volatility has also been at the centre of Japan's economic troubles over the last decades, and emphasis remains on housing and the housing market in strategies to restructure and regalvanize the Japanese economic machine.

This book seeks to put together a number of perspectives on the Japanese housing system in order to provide a comprehensive and multifarious account of the dynamic role of the housing system during a period of unprecedented social and economic change in one of the most enigmatic social, political, and economic systems in the industrial/post-industrial world. We explore the nature of the Japanese housing system, focusing on how it is embedded in the wider structure of social and economic transformation. While Japan demonstrates many of the characteristics of western housing and social systems, including mass home ownership and consumption-based lifestyles, extensive economic growth and rapid urban modernization has been achieved in balance with an assertion of many indigenous social values and practices. The case of Japan illustrates the diversity of modern housing systems as well as the embeddedness of housing in social diversification and broader processes of social change and economic development. 


\section{The rise and fall of the post-war Japanese housing system}

The Japanese housing system in the post-war period developed in a very particular context. A key element, which characterized the basic course of postwar Japanese society, was the effort made to catch up with western 'advanced' nations, particularly in terms of economic productivity, where 'modernization' was often equated with 'westernization'. The formation of the housing system in Japan, as in western countries, was associated with the expansion of housing construction, mortgage markets, the growth of the owner-occupied sector and government intervention in the housing market. Nevertheless, the trajectory of the housing system in Japan has been distinctive and strongly differentiated from that of western societies.

From the end of the war through the 1970s, the massive inflow of population into urban areas and the considerable increase in the number of households put increasing stress on the demand for housing, which led to the acceleration of housing construction. The economy developed at a striking pace with an average annual growth of approximately 10 per cent between the middle of the 1950s and the early 1970s. An increasing number of middle-class families were nurtured by state policies and expected to purchase or build their own home. There was a cycle in which the mass construction of owner-occupied housing stimulated economic growth which, in turn, expanded the acquisition of owner-occupied housing. Since housing prices initially rose rapidly and stably, owning a house, which was accompanied by a considerable capital gain, was an effective means of accumulating a valuable asset. The combination of economic development, a growing middle class and mass home ownership was increasingly regarded as central to social stability. The conservatives formed the LDP (Liberal Democratic Party) in 1955 and have almost exclusively held power ever since. Critically, they have been concerned with economic growth through the promotion of mass production of owner-occupied housing, backed by strong connections in business circles, and in particular the construction, housing and real estate sectors.

While the post-war Japanese state sought to catch up with the levels of development of western countries, by putting overwhelming priority on economic growth, the nature of development completely diverged from that of European welfare states that had emerged in the immediate post-war period, in terms of the formation of housing provision strategies (Harada, 1985; Hirayama, 2003a; Holliday, 2000; Izuhara, 2000; Ohmoto, 1985; Ronald, 2004). Japanese governments have never set out to expand the social housing sector nor accepted the concept of universal citizenship rights to housing. In the post-war period, while education and health services have developed relatively universally and comprehensively among various public welfare provision programmes, direct provision of housing welfare has been placed in a residual position. Nevertheless, the fact that Japan did not adopt European welfare state models does not imply 
that the Japanese government has not been concerned with housing provision. The relationship between the state and housing in post-war Japan developed in very specific terms. Centrally, since the period immediately after the war, the Japanese government has sought to nurture the creation of a society and an economy orientated around the middle classes and middle-class home ownership (Hirayama, 2003a).

Private home ownership has been the dominant housing tenure in Japan. According to the Housing and Land Survey in 2003, the level of owner-occupied housing was 61.2 per cent. The home ownership sector was vigorously stimulated by generous state subsidy along with economic development and the growth of the middle class. The ratio of private rental housing was the second highest at 26.8 per cent. However, the government has never directly supported private rental housing. There has been little assistance for the construction of private rental housing and absolutely no provision of rental subsidy. Direct provision of rental housing by the public sector has been residual. The ratio of publicly rented housing was 6.7 per cent.

The housing system in Japan was essentially workable under unparalleled conditions of economic growth and social stability. Over the past few decades, however, the housing context has been transformed by a more volatile, uncertain economy and increasing social fragmentation. Many academics and popular discourses assert that the 1990s generated a turning point for Japan in terms of the overall restructuring of social, economic, political and institutional orders. The housing system is no exception, and has indeed been central to the structure and effect of transformation. The so-called bubble economy, which began with the unprecedented rise in real estate and stock prices in the latter half of the 1980s, collapsed at the beginning of the 1990s. Throughout the 1990s and in the early 2000s, Japan experienced the worst recession of the post-war period, with an increasing social destabilization of the middle classes. The 1990s have become known as the 'lost decade' in Japan. When the bubble burst, land and housing prices fell sharply for the first time since the end of the war, and the security of residential property as an asset was fundamentally undermined (Forrest et al., 2003; Hirayama, 2003b).

Demographic composition has also been dramatically changing due to an unprecedented increase in the elderly and a drop in the fertility rate. While the proportion of conventional family households is in decline, single, elderly-only and couple-only households are increasing. As regards to politics, it has become difficult for the LDP to remain in power without forming reluctant coalitions with the other parties. Public faith in the state has been in decline and value systems have begun to unravel in tandem with the new social and economic realities the Japanese face. Consequently, the nature and function of household formation and the traditional housing system in Japan is undergoing a marked and fundamental transition. 
Since the middle of the 1990s, the system of housing production and consumption has been increasingly deregulated, moving clearly towards a greater emphasis on market mechanisms (Hirayama, 2005; Oizumi, 2002). In an increasingly globalized economic environment, the housing system in Japan, as in many other countries, has been experiencing volatile economic conditions, greater social fragmentation and pressure to cut back on social spending and public subsidies. In context of the broader structure of change, there have been similar trends between Japan and other industrialized countries in terms of attempts to promote market-based housing provision. This does not mean that there is a convergence in housing systems among industrialized societies including Japan. The interaction of broader trends and indigenous local contexts in each society will lead to a more diversified variety of housing systems and it is expected that the nature of Japan's housing system will not be normalized by globalizing forces but will maintain its distinctiveness.

As housing has been the corner stone of the social mainstream, a catalyst of economic growth and the basis for social and welfare relationships, volatility in the housing market, fragmentation of households and value systems, and the growing demographic imbalance between young and old, have put the housing system under considerable strain and begun to test sustainability. At the beginning of the twenty-first century, after more than a decade of economic insecurity and stagnation, the government has begun to take more radical steps in social and economic policies. Housing is again at the centre of transitional initiatives to revive Japanese cities, elevate the global status of the capital (Saito and Thornley, 2003), and revitalize the economy through increased marketization and reconstruction (Hirayama, 2005).

\section{Housing and social transition in Japan}

Housing research in the international academic arena has been developed and dominated mainly by western-based researchers, and so housing theories and empirical research have developed in terms of western norms. The experiences of Japan as well as other non-western industrialized countries, however, demonstrate considerable diversity among modern housing systems and the ways in which housing is intertwined with broader processes of social and economic change. In most cases of comparative housing research led by western researchers, the housing situations in non-western societies have been tacitly characterized as 'unique', 'enigmatic', 'exceptional', 'ethnic', 'underdeveloped' or 'lagging cases', and been seen as useful as long as they reinforce dominant theories.

Although there has been a growing body of housing research and literature within Japan, like many industrialized societies outside the occident, it has been largely ignored unless it has been expressed in English or appeared in European 
and North American literatures. The specific consideration of housing and social change in Japan in English has been dominated by historical approaches or an emphasis on Japan's special architectural and urban characteristics. Normative comparative understanding of Japanese housing systems and practices remain largely undeveloped. Critically, in understanding the increasing diversity of housing systems in the modern world, comparative approaches must be more diversified, based on insights on housing practices and networks in each society, and grounded in indigenous context.

Beyond housing, there is little consensus on how to approach the analysis of social change in Japan more generally. Western models of interpretation of Japanese society have arguably been ethnocentric, based on assumptions about social structures and subjectivities. Models like those of Nakane Chie (1973) of the 'Vertical Society', Ruth Benedict's (1947) 'Moralist' model and Chalmers Johnson's (1982) 'Developmental State' continue to exercise influence despite empirical and theoretical flaws and the scale of social and economic change in Japan in recent decades. Within Japan, discourses of 'Nihonjinron' or theories of Japaneseness, which emphasize the unique aspects of Japanese culture, have until recent years also dominated perceptions of social processes, and while some have been critical of exclusivist currents (Dale, 1986), others have identified the benefits of applying an approach free of the universalism and 'pervasive rationalism of western social thinking' (Clammer, 1995).

This volume analyses housing in the case of Japan with the aim of contributing to the de-construction of the dominant norm in housing studies and the diversification of the understanding of relationships between housing and social change. Perspectives will be drawn together from Japan-based authors engaging with Japanese society in terms of housing as one of its most central and dynamic elements, and central to contemporary issues concerning social change and emerging social inequalities. Our approach reflects debates that are currently being played out within the Japanese policy sphere and academic forum with particular reflexivity to comparative theoretical discourses concerning housing and society, and political and economic developments globally. The main purpose of this book is to consider different elements of the housing system and different aspects of related social change in Japan in context of their implications for understanding housing and social transformation in general as well as the consequences for Japanese society itself.

Western political-economists have focused on recent social change in Japan in terms of reform of the institutional structures which maintain the core character of 'Japanese economic nationalism' (Schaede and Grimes, 2003), while social theorists have focused on the effects of economic change on consumption and patterns of identification (Clammer, 1995, 1997). Our approach to social change in Japan, by focusing on housing as a point of interaction between macro socioeconomic forces and micro subjective relations, incorporates structural elements 
as well as social relationships and identities. Each chapter deals with different elements of the housing and social system, from individual, family and cultural processes to policy, political economy and state responses. Moreover, each chapter engages with theories and literatures derived both within and without Japan.

In advanced industrialized societies, housing defines social relationships and signifies the class and status of the household or neighbourhood. Housing and the home is a source of identity and identification (Rapoport, 1981) and has been emphasized as a critical locale for the 'self' and ontological security (Saunders, 1990). Furthermore, housing shapes economic relationships between individuals, households, institutions and the state, especially where family-owned properties constitute a household's largest investment and asset, and reservoir for individual and family welfare exchanges and services. The housing system also mediates the relationship between capital, the most mobile element of the economic sphere, and land, the least mobile (Stephens, 2003), and thus links domestic economic processes with national and international ones.

Japan's system of housing is particularly central to economic development as well as family welfare, employment, security, inequality and social-class relations - perhaps more so than any other advanced industrialized economy. Indeed, Japan's brand of capitalism and modernity is peculiar by western expectations, which offers substantial opportunities to examine the relationships between housing and society in conditions which contrast substantially with those assumed in mainstream housing and urban studies (Ronald, 2004).

'Transition' is an important way of considering social processes and the dynamics of modernity, and how different elements of the social system interact and develop. During conditions of turbulence the Japanese government has in the past turned to housing policy as a means to stabilize families and influence economic recovery and growth. In the early post-war era, catching up with the economies and societies of the West was the main objective of social and economic policies. Since the collapse of the economic bubble in the early 1990s, however, the direction of policy and social development has become unclear and 'fragmentation', 'confusion' and 'anxiety' have become the zeitgeist watchwords, while the government has begun to rally around 'marketization' and 'deregulation' as solutions to apparent crisis. As 'transition' also implies a state of transformation to an undefined future state, it is particularly apt in consideration of the state of the Japanese housing and social system at the beginning of the twenty-first century.

For early post-war generations, housing provided stability and, due to the expansion of home ownership, a means for families to accumulate substantial capital assets. Since the 1990s, however, the natures of housing markets, global economic pressures and changes in employment structures have led to increasing instability. The vicissitudes of the Japanese housing market have become entangled with global patterns of volatility, instability and transformation. Japan stands on a unique axis as a mature industrialized economy with modernized social and 
economic structures and institutions similar to western societies, but also as a non-western, culturally distinct society located at the heart of the Asian politicaleconomic nexus. Japan's position in the world economy and its growing integration with East Asian economies has mediated a specific pattern of development in recent decades where housing markets and housing investments are playing an increasing part in the security of households, bolstering economic growth and the restructuring of markets and finance.

The nature and pattern of social transformation in Japan, therefore, provides the opportunity to gain critical and substantial insights into the effects of globalization and social change on a specific housing system and society. How Japan is changing has become a central topic of socio-economic analyses as Japan resisted global rules for its domestic markets for decades and appears to be continuing to attempt to manage the effects of globalization via practices of 'guided markets' and 'managed competition' (Schaede and Grimes, 2003). Even Japan's recent renewed commitment to restructuring, deregulation and the principles of neoliberalism, appears constrained by bureaucratic processes and conflict between the conservative and more radical elements within the ruling political elite.

How local elements interact with globalization is largely unpredictable and the forces of globalization, whether they are ideological, social or economic, are leading to different types of developments in different parts of each society. The effects of wider changes on the housing situation are thus subject to the social, economic, political and institutional contexts of particular countries, and Japan has demonstrated some specific and peculiar outcomes in relation to the housing sphere. Essentially, the Japanese housing system is undergoing drastic changes due to the increasing uncertainty of economic conditions and the fragmentation of the social structure, and its new direction is unclear at present. More universally, the combination of broader changes and indigenous contexts are leading to the production of more diversified housing systems. As a new housing system emerges in Japan, it will be influenced by wider trends but with localized effects, and will move along a new trajectory radically divorced from the earlier context of policy and system development. What is increasingly apparent, and what is a central message of this book, is that housing matters and has become critical in the shaping of socio-economic relationships and changes at multiple levels across and beyond Japanese society.

\section{Examining the housing system}

This book considers the dynamic relationship between the housing system and social transition in terms of numerous elements and perspectives. Each chapter deals with a particular aspect of housing and change in Japan and can be read as an individual paper in its own terms. However, there are a number of key phenomena that are consistently addressed in determining the post-war trajectory of housing 
and society. Rapid economic growth and urbanization have been fundamental contextual elements, as well as the growth of the company system, political stability and the formation of a middle-class social mainstream and 'standard family' model.

In the post-economic-bubble environment of the twenty-first century there are three critical dimensions which have become more definitive in shaping social changes. The first is demographic, as Japan has begun to demonstrate the effects of societal ageing (the over-65-year-old age group accounted for 19.5 per cent of the total population in 2004) and declining fertility (the fertility rate, indicating how many children an average woman is expected to give birth to, was 1.29 in 2004). This has not only eroded the established system of housing, where the foundations of the housing ladder have been undermined and household formation and intergenerational relations have begun to fragment, but also challenged the sustainability of the society itself where the total population is expected to decline radically (by more than 7 per cent over the next 25 years), and the economically active population is increasingly stretched by the demands of an expanding elderly population. The second dimension is economic as the period of rapid economic growth has painfully drawn to a close, and companies, households and the state are increasingly under pressure to survive in an unfamiliar context of economic stagnation, growing global competitiveness and a post-fordist restructuring of production and employment. The third dimension is policy-based. After more than a decade of economic decline, the state has had to reorientate its practices, perspectives and goals. The socio-political climate has shifted towards a neoliberal agenda where privatization, deregulation and marketization have become prioritized over traditional principles of benign authority, social solidarity and mutual assistance.

In chapter 2, Hirayama sets out in more specific terms the emerging relationships between the state, housing policy and social formation identified at the beginning of this chapter. In the early post-war environment home ownership and housing construction were seen as engines for both economic growth and middle-class formation and Hirayama's argument is that the housing system has indeed been a central catalyst, determining much of the force and direction in socio-economic change following the war. The policy pillars of the modern housing system were established in the early 1950s, and by the 1980s Japan had surpassed housing shortage problems and entered an era of oversupply. Essentially, the early postwar housing context established owner-occupation and a housing ladder that became definitive in forming a middle-class social mainstream society where the accumulation of housing assets was central.

The bursting of the economic bubble at the end of the 1980s initiated a period of economic volatility and market decline leading to the destabilization of the owner-occupation orientated housing system. Housing trajectories have been increasingly differentiated while the security and value of housing assets have 
diminished. New social, spatial and economic patterns are emerging in urban areas which have been increasingly determined by the characteristics of housing markets and residential development. In terms of policy, housing has been dropped from the social agenda and instead the government has sought to deregulate and marketize. This reorientation reflects a new stage and logic in policy, but sustains the principle that housing has broad-scale socio-economic impacts and is a catalyst for social change.

The structure of the housing system is examined further in chapter 3 where Oizumi engages with the changing dynamics of the housing industries. Housing construction in Japan is highly accelerated with a volume of production that far exceeds (by as much as fivefold in some cases) the relative levels of building per capita in Europe and North America. Housing construction experienced substantial and sustained growth in the post-war decades, but this sector too has been fundamentally challenged by post-bubble social and economic changes. The structures of the housing industries are currently in flux, and the way they react to changing conditions will define economic conditions for households and will shape urban environments. Specifically, Oizumi considers how the downturn in the economy and housing market affect, first, structures of housing finance, and second, the construction industry.

The government housing loan system has been at the heart of the post-war home ownership system. However, as a result of policy shift this traditional structure of housing finance will be demolished in order for banks and private interests to expand into the housing loan market. This change threatens to destabilize the current balance within the housing finance system and deregulation will exacerbate housing and financial problems for more vulnerable households. Housing stock and construction practices in Japan have a very peculiar character, dominated by the 'scrap and build' system and the control of house-building companies. Within the construction sector, intensified competition and concentration among house-builders has been a result of changing market conditions. The sector has responded by putting renewed pressure on the government to deregulate further and stimulate more construction. Oizumi's argument essentially asserts that housing finance and construction are key macro elements which interact strongly with socio-economic factors. Furthermore, these elements are in transition which may destabilize relationships and have long-term repercussions.

The nature of welfare housing is complex in Japan and is also facing many similar pressures to the private housing sector. In chapter 4 Sato illustrates the residual nature of Japanese social housing policy and the unusual and substantial support the sector has received, historically, from the corporate sector. Housing as a welfare good, in terms of both subsidized rental and owner-occupied tenure, has been fundamentally supported by the 'company society', and firms have taken up the responsibilities for housing workers that are normally taken on by the state in other industrialized societies. Sato explores the theoretical context 
of welfare regime theory, identifying how poorly Japan meets traditional models and classifications and how significant corporate housing benefits have been in the housing system. He goes on to consider how corporate welfare has shrunk in recent years as a result of the economic sea change, the restructuring of the employment market, and the adjustments companies have made to their company housing property assets and employee housing subsidy packages.

One of the key social changes consistently identified in contemporary Japan is the growing number of older people as a proportion of the population. Japan demonstrates an extreme form of a demographic pattern that will have considerable effects across advanced industrial societies. In chapter 5 Izuhara explores changing relationships, in the post-bubble context, between generations of households and housing assets. In Japan, older generations hold a large amount of the accumulated national wealth which the government has began to target in its strategies to revitalize the economy. However, much of this equity is held in the form of housing and property assets and older generations tend to be 'asset rich-cash poor', which ties up capital. The baby-boomer generation in Japan has been a critical one in that it forged post-war family formation, led the inflation of the economic bubble and shaped the modern housing market. It is now seen as the generation that is driving societal ageing, and is associated with growing problems of dependency and the potential crisis in pensions.

Izuhara begins by setting out the significance of the policy debate in this area and the growing impetus of asset-based approaches to public policy. She explores the pattern of social policy and socialization of care, and how changing family and household relations are being impacted. State policy has set out to encourage the release of wealth from older generations who increasingly need to support themselves and provide for care from the assets accumulated over their lifetimes. The chapter considers in depth different strategies by which older generations are able, or not, to liquidize housing assets and the subsequent effects.

In chapter 6 Hinokidani focuses attention further on the role of family and family formation, identifying the incongruities between housing, social policy and household needs. A critical contemporary change in Japan has been the decline in the 'standard family' model and lifecycle pathway. Individual living and households of couples without children have expanded rapidly in recent decades while appropriate and affordable dwelling types have been undersupplied. At the same time suitable family housing has been predominantly supplied in the owner-occupied sector and is fundamentally lacking in the private rental sector. Hinokidani considers the situation of women, and the needs of the growing number of women outside the 'standard family' model, in particular. The role of women in social life as well as the economy has been undergoing considerable transformation. Policy frameworks, institutional approaches and support systems have lagged substantially behind this transformation. Housing conditions have been a considerable obstacle to improving life chances and enhancing the quality of 
living for many families, and in particular female-headed households. Hinokidani critically identifies that there are many common features to women's experiences of the built environment across societies, but that social and institutional responses have varied depending on the features of housing and the housing system as well as social norms. Japan's built environment and social values demonstrate a peculiar pattern among advanced industrialized nations, which has structured particular patterns of marginalization and social inequality.

Problems of social exclusion and inequality are explored further in chapter 7 in relation to the most marginal of housing groups, the homeless. Iwata considers how social changes in the nature of family support as well as economic changes in the employment structure have mediated new patterns of inequality. Massive increases in homelessness and street living have been a highly visible symptom of the post-bubble economy, and mark a substantial transition in the condition of Japanese society. 'Social exclusion' is a key analytical concept for understanding the character of homelessness in a society, and has largely been ignored in the understanding of social disadvantage in Japan. Iwata argues that homelessness should be thought of as a special form of exclusion within a framework of contemporary socio-economic change, and not as a surface phenomenon of poverty and inequality.

Iwata focuses on street homelessness in Tokyo and the processes by which people ended up in this condition. The features of its homeless community are very specific to the Japanese context. The homeless are predominantly older men who have either never married or are divorced. They largely have a poor education and many come from a particular category of marginal employment prior to becoming homeless. One of the biggest groups comes from the construction industry day labourer sector which has been hard hit in the postbubble economy. As well as considering a typology of the homeless based on survey research, Iwata considers government practices and policies that have sought to deal with the homeless through inclusion. These policies have taken the form of either inclusion through work or inclusion through housing. Iwata also addresses the relative pitfalls and successes of each of these approaches as well as central mediating factors.

Housing not only concerns policy, buildings and residential practices, it is also at the centre of a broad network of social, cultural and political relations. Dwelling and dwellings have been radically transformed by urbanization and modernization, and they represent a key element in understanding how each society manifests its unique brand of modernity. Chapter 8 considers policy change and socio-economic developments in Japan in more socio-historical terms, dealing with the house and home as a nodal point of social relations. The interaction of dimensions of tradition and modernization in housing and social life are critical in understanding modern Japanese society. The resignification of the home specifically, as an owner-occupied family commodity that stimulates 
middle-class identification, has been achieved while retaining strong associations of the house and traditional social values and relations.

Ronald examines the origins of the modern housing system beginning with the Meiji restoration in the second half of the nineteenth century in order to identify sustained aspects of social change in the process of modernization. He addresses changes in the meaning of the house and home and the physical form of dwellings as crucial elements that have mediated the interaction of the self, society and the built environment. The concept of $i e$, meaning the house, home or family, has historically been at the heart of Japanese culture and social organization, and in the pre-modern era defined hierarchical relationships within and between the household and society. Early modernizers sought to transform ie as a means to modernize and, to a lesser extent, westernize the family and society. Post-war reform sought more radical change in household behaviour and the built environment that would support the political hegemony and socio-political stability, and would drive economic expansion. Despite radical social change, the concept of $i e$ and the idea of traditional family relations have remained central in modern housing processes, where houses have become commodities. Essentially, Ronald argues that $i e$ and houses themselves have undergone radical transformation while at the same time mediating stability and continuity in identification processes and social relations. In the post-bubble environment the housing system has come under considerable strain and the integrity of $i e$ and modern housing practices have been undermined by market decline and social fragmentation.

The final chapter attempts to situate the Japanese housing system within prevailing models of understanding of the role of housing in advanced industrial societies. Convergent themes from each of the chapters are brought together in order to demonstrate the role housing has played in facilitating stability as well as patterns of social change. We ultimately seek to evaluate developments in housing policy and system elements, accounting for their potential influence in future transformations in Japanese society. In more universal terms, we also explore how Japan conceptually fits and challenges prevailing conceptualizations of housing and social change. While Japan has traditionally proved a problematic fit in western models of housing and social policy, recent theorizations have tried to integrate the Tiger economies of East Asian societies within a typology that accounts for greater regional variation in welfare capitalism where housing and home ownership assets are central politically and economically (see EspingAndersen, 1997; Doling, 1999; Holliday, 2000; Ronald, 2005). An obstacle to integrating a model of East Asian societies has been the fundamental complexity and diversity of policy and systems approaches across this group. Our argument also attempts to identify how housing plays a role in mediating both the convergent forces of globalization of capital and the particularising forces of local systems, practices and values. 


\section{References}

Benedict, R. (1947) The Chrysanthemum and the Sword: Patterns of Japanese Culture, London: Secker \& Warburg.

Clammer, J. (1995) Difference and Modernity: Social Theory and Contemporary Japanese Society, New York and London: Kegan Paul International.

Clammer, J. (1997) Contemporary Urban Japan: A Sociology of Consumption, Oxford: Blackwell.

Dale, P. N. (1986) The Myth of Japanese Uniqueness, London: Croom Helm and the Nissan Institute.

Doling, J. (1999) Housing policies and the little tigers: how do they compare with the other industrialized countries, Housing Studies, 14(2): 229-50.

Esping-Andersen, G. (1997) Hybrid or unique? The Japanese welfare state between Europe and America, Journal of European Social Policy, 7(3): 179-89.

Forrest, R., Kennett, P. and Izuhara, M. (2003) Home ownership and economic change in Japan, Housing Studies, 18(3): 277-93.

Harada, S. (1985) Sengo juutaku housei no seiritsu katei (The establishment process of housing laws in post-war Japan), in Institute of Social Science, Tokyo University (ed.) Fukushi Kokka, vol. 6, Nihon no Shakai to Fukushi (The Welfare State, vol. 6, Japanese Society and Welfare), Tokyo: Tokyo University Press, pp. 317-96.

Hirayama, Y. (2003a) Housing policy and social inequality in Japan, in M. Izuhara (ed.) Comparing Social Policies: Exploring New Perspectives in Britain and Japan, Bristol: Polity Press, pp.151-71.

Hirayama, Y. (2003b) Home ownership in an unstable world: the case of Japan, in R. Forrest and J. Lee (eds) Housing and Social Change: East-West Perspectives, London: Routledge, pp.140-61.

Hirayama, Y. (2005) Running hot and cold in the urban home ownership market: the experience of Japan's major cities, Journal of Housing and the Built Environment, 20(1): 1-20.

Holliday, I. (2000) Productivist welfare capitalism: social policy in East Asia, Political Studies, 48: 706-23.

Izuhara, M. (2000) Family Change and Housing in Post-War Japanese Society: The Experiences of Older Women, Aldershot: Ashgate.

Johnson, C.A. (1982) Miti and the Japanese Miracle: The Growth of Industrial Policy, 1925-1975, Tokyo: Charles E. Tuttle.

Nakane, C. (1973) Japanese Society, Harmondsworth: Penguin Books.

Ohmoto, K. (1985) Fukushi kokka to wagakuni jutaku seisaku no tenkai (The welfare state and housing policy in Japan), in Institute of Social Science, Tokyo University (ed.) Fukushi Kokka, vol. 6, Nihon no Shakai to Fukushi (The Welfare State, vol. 6, Japanese Society and Welfare), Tokyo: Tokyo University Press, pp. 397-455.

Oizumi, E. (2002) Housing provision and marketization in 1980s and 1990s Japan: a new stage of the affordability problem?, in G. Dymski and D. Isenberg (eds) Seeking Shelter on the Pacific Rim: Financial Globalization, Social Change, and the Housing Market, New York: M.E. Sharpe, pp. 169-86.

Rapoport, A. (1981) Identity and environment: a cross cultural perspective, in S. Duncan (ed.) Housing and Identity: Cross-cultural Perspectives, London: Croom Helm.

Ronald, R. (2004) Home ownership, ideology and diversity: re-evaluating concepts of housing ideology in the case of Japan, Housing, Theory and Society, 21(2): 49-64. 


\section{Yosuke Hirayama and Richard Ronald}

Ronald, R. (2005) Comparing homeowner societies: can we construct an East-West model? Paper presented at the Asia Pacific Network for Housing Research Conference, 'Housing and Globalization', Kobe University, Japan, September.

Saito, A. and Thornley, A. (2003) Shifts in Tokyo's world city status and the urban planning response, Urban Studies, 40(4): 665-85.

Saunders, P. (1990) A Nation of Home Owners, London: Unwin Hyman.

Schaede, U. and Grimes, W. (2003) Japan's Managed Globalization: Adapting to the Twenty First Century, Armonk, NY: M. E. Sharpe.

Stephens, M. (2003) Globalization and housing finance systems in advanced and transition economies, Urban Studies, 40(5/6): 1011-26. 


\title{
2 Reshaping the housing system

\author{
Home ownership as a catalyst for \\ social transformation
}

\author{
Yosuke Hirayama
}

\section{Introduction}

In post-war Japan, the housing system has driven the expansion of home ownership as a means to facilitate the formation of a middle-class society. Associated with vigorous economic growth, an expanding group of households on middle incomes emerged who were able to purchase their own housing. In addition, the massive inflow of the population into urban areas and a rise in the number of households provoked a tremendous demand for housing, which accelerated housing construction and further supported economic growth. It was assumed that many people in middle-class society led a 'standard life-course' and formed nuclear families constituting a normalized form of the 'standard household'. As the prices of land and housing rose rapidly, owning a house, which produced a considerable capital gain, was an advantageous means of accumulating assets, and an increasing number of households designed their life-courses with a view to eventually becoming a homeowner. The housing system has operated as an instrument not only to provide housing, but also to transform social and economic conditions. A clear orientation towards the production of a 'social mainstream' was thus evident in the post-war housing system, in which the increase in middleclass families promoted home ownership and the development of the owneroccupied housing sector in turn nurtured the middle classes (Hirayama, 2003a; Ronald, 2004).

The strategy of the government in forming housing policy was directed towards encouraging middle-class home ownership. The so-called 'three pillars' of post-war housing policy were systematized by: the GHLC (Government Housing Loan Corporation) Act of 1950; the Public Housing Act of 1951; and the JHC (Japan Housing Corporation) Act of 1955. The GHLC, a state agency, provided middle-income households with long-term, fixed low-interest 
mortgages in order to facilitate access to home ownership. Public housing, subsidized by the national government, and constructed, owned and managed by local governments, was provided for low-income people with subsidized rents. The JHC was founded as an agency of the state to develop multi-family housing estates for middle-income households in large cities. The 'three pillars' of housing policy were not given equal priority. The government has particularly emphasized the provision of GHLC loans to facilitate home ownership while the direct provision of public housing has increasingly been residualized. The explicit bias towards encouraging the owner-occupied sector and the generous support for middle-class household housing purchase has been at the heart of housing policy in post-war Japan (Harada, 1985; Hayakawa, 2002; Hirayama, 2003a; Ohmoto, 1985). Essentially, the combination and interaction of a growing middle class and home ownership were regarded as key factors in stabilizing socio-economic conditions.

The housing system and its socio-economic base, however, lost stability in the last decade of the twentieth century. The collapse of the so-called 'bubble economy' at the beginning of the 1990s triggered an economic crisis - a long recession, a rising unemployment rate, a decline in income and a chain reaction of enterprise bankruptcies. Owner-occupied housing, which used to produce capital gains, began to generate capital losses and the security of residential property as an asset was undermined severely. Associated with a more volatile, uncertain economy, the function of the housing system to promote home ownership has been weakening. The demographic composition of society has also been drastically transformed due to an unprecedented increase in the elderly and a drop in the fertility rate. The proportion of conventional nuclear family households is in decline, and single, elderly-only and couple-only households are increasing (see Izuhara and Hinokidani, in this volume). What will have the greatest impact on social and economic organization in the foreseeable future is a rapid decrease in the total population. As life-courses and household formation have become varied, the concept of a 'standard household' and a 'standard life-course' has lost its salience and former generality in the current demographic context. At the beginning of the twenty-first century, the basis of middle-class society grounded on home ownership is becoming less clear.

Since the middle of the 1990 s, the government has radically geared its housing policy towards accentuating the role of the market in providing and financing housing, and has begun to dissolve the traditional 'three pillars'. The GHLC will be abolished by the end of the fiscal year 2006 and its successor, the Housing Finance Agency, will withdraw from the primary mortgage market and, thereafter, deal only with the secondary market of mortgage securities. The JHC was reorganized into the HUDC (Housing and Urban Development Corporation) in 1981, then into the UDC (Urban Development Corporation) in 1999 and again into the URA (Urban Renaissance Agency) in 2004. The new URA retreated almost completely 
from construction of new housing. New starts of public housing for low-income households have almost stopped and its role in housing policy will be residualized even more. Critically, the conventional framework of housing policy has been broken up and the relationship between the government and the market in terms of housing provision is entering a period of fundamental restructuring.

This chapter explores the processes and implications of transformations in the housing system in present-day Japan with particular reference to the changing nature of home ownership. Until the middle of the 1970s, there was an acute housing shortage, and the housing system was pressed to produce a large number of dwellings to meet the people's housing needs. The mass construction of housing, particularly owner-occupied housing, played a significant role in addressing the housing shortage and improving housing conditions. Since the 1980s, a housing surplus has been seen with a rise in the vacancy rate, marking the mitigation of conventional housing problems. On the other hand, however, the system of housing provision has increasingly been embedded within the wider structure of social and economic transitions and the role of home ownership as a way to facilitate socio-economic restructuring has become unpredictable. The housing system, which used to devote itself to housing production, should now be understood in the context of broader change. The chapter not only looks at owner-occupied housing but also highlights home ownership as a catalyst for wider social transformations.

\section{Home ownership and middle-class society}

Before we explore the contemporary restructuring of the home ownership system, it is necessary to look at the traditional post-war framework of housing provision. Home ownership promotion facilitated by the housing system has been heavily implicated in economic development and the formation of middle-class society. This section thus provides an appreciation of the nature of the conventional home ownership oriented housing system as being interconnected with the shaping of the post-war socio-economic order.

The continuity or intermittence of Japanese society before and after the war can be looked at from various angles. When focusing on post-war change, however, one of its most clear-cut elements is the expansion of home ownership. According to a survey on housing situations in major cities, conducted by the government in 1941, the proportion of owner-occupied houses was only 22 per cent while that of private rental houses exceeded 70 per cent (Hayakawa and Ohmoto, 1988). The Rent Regulation Ordinance during and immediately after the war discouraged the provision of private rental housing and subsequently an increasing number of owner-occupied private houses began to be built (Miyake, 1985). Within a short period after the end of the war owner-occupation became the dominant housing tenure, and by the 1950s the level of home ownership increased to more than half 
the housing stock. Critically, post-war Japanese society was characterized by its rapid transformation into a 'homeowner society' (Sumita, 1980).

The housing system framework of home ownership expansion was established during the period of high-speed economic growth in the 1950s and 1960s. Along with accelerated development in industry and the economy, an increasing number of middle-class families were encouraged to acquire their own homes. As urbanization intensified and the number of households rose due to a transformation in the dominant form of household from an extended family household to a nuclear household, the increasing demand for dwellings facilitated the mass construction of housing, which in turn stimulated economic growth further. The prices of land and housing rose rapidly and continuously, and at a much higher rate than income and consumer prices, which meant that owner-occupied housing provided owners with considerable capital gains. Underlying the development of home ownership therefore was the structural interconnection of economic growth, mass demand for housing, the expansion of the middle class and house price inflation. The rise of 'homeowner society' essentially corresponded with the formation of an 'affluent society', which dynamically restructured social and economic landscapes in postwar Japan.

The government played a key role in creating the home ownership oriented housing system. Among the 'three pillars' of housing policy, the provision of GHLC loans has particularly been emphasized in promoting home ownership. Despite rapid urbanization, the level of owner-occupied housing has remained at around 60 per cent between 1963 and 2003 due to the measures used to accelerate housing acquisition (see Table 2.1). The ratio of private rental housing has been the second highest at around 25 per cent. However, housing policy has not directly supported private rental housing. There has been little assistance for the construction of private rental housing and absolutely no provision of rental subsidy. Direct provision of rental housing by the public sector has been regarded as a marginal measure. The ratios of public housing and JHC rental housing to total housing have been very low, at around 5 per cent and 2 per cent, respectively.

The housing system divided mainstream society into an inside and an outside, generating a 'social flow' of people moving from the outside into the inside. The boundaries dividing society were drawn between those on low incomes and those with higher incomes, and between renters and homeowners. The filtering (or trickledown) system elaborated a 'housing ladder' in which people were expected to move from a rental dwelling to an owner-occupied dwelling, and from a condominium to a single-family home. Mai homu, meaning 'my own home', and niwatsuki ikkodate jutaku, meaning a 'single-family house with garden', were located on and represented the top of the ladder. The housing system, which concentrated resources inside mainstream society, subtly coerced people into climbing the 'housing ladder' and encouraged those outside to join the 'social flow'. 


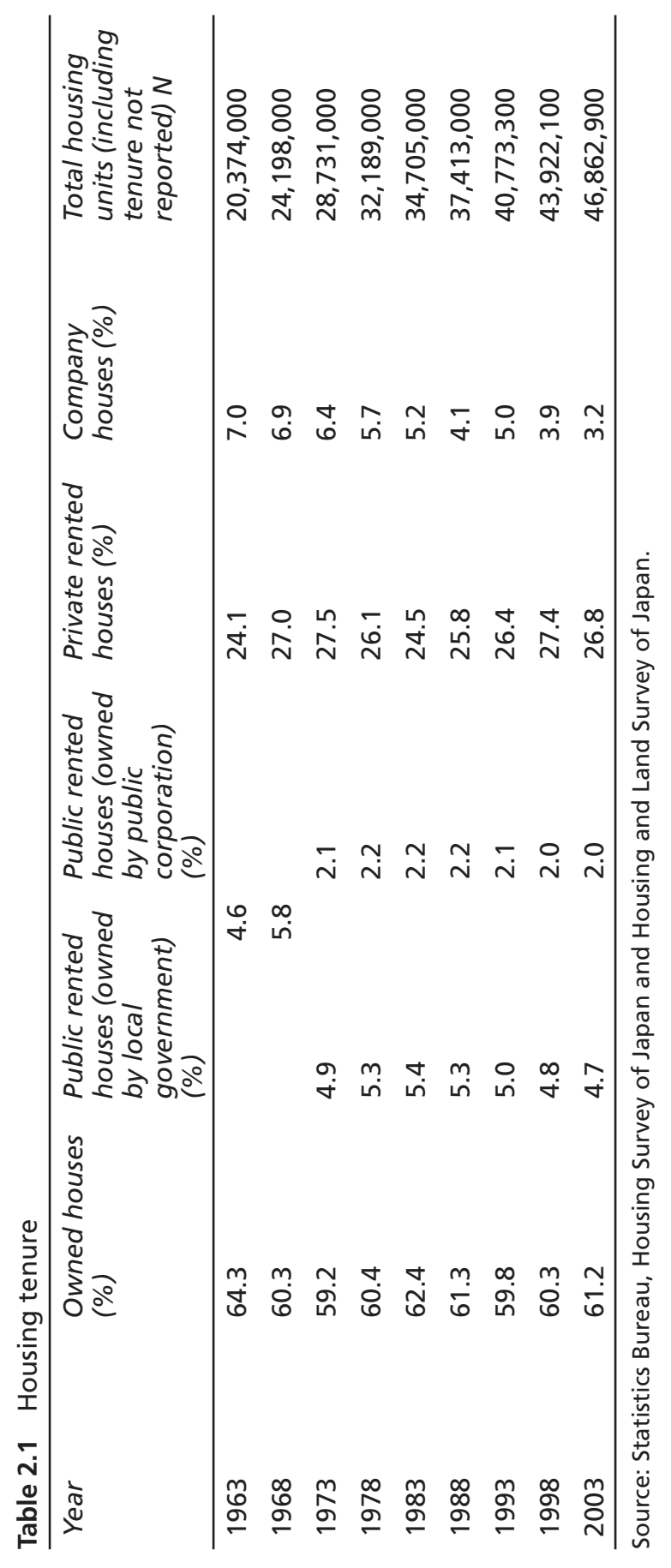


The system of housing provision functioned as a means to expand middle-class home ownership. The tenure of housing has correlated very closely with the age and income of a household. A young family is likely to live in a rental dwelling of relatively poor quality since their income tends to be low. However, as the family advances in age, their income generally increases so that they are likely to be able to purchase a better quality house. The aggregation of moves of people climbing up the 'housing ladder' created a 'social flow' which swelled the 'homeowner society'. Housing policy, which vigorously promoted home ownership by means of GHLC loans, allotted the largest part of public funds to middle-income groups rather than low-income groups. This distributive pattern of public resources biased towards the better-off was rationalized in terms of the effectiveness of the filtering system, which was thought to improve the housing conditions of the lower classes through the chain reaction of household moves.

Japanese society is often referred to as a 'company society', and companies have played an important part in reinforcing the housing system (Ohmoto, 1996; see also Sato, this volume). A lifelong employment system and a seniority system for wages and promotion provided employees with a steady increase in income and thus enabled them to aggregate substantial financial stability for housing purchase. Major corporations implemented in-house systems to support their employees in securing housing, which was embedded in the filtering system. Employee housing and rental subsidies were supplied for young employees, while employees at a later stage of the housing ladder could utilize a company loan system to purchase a house. The bigger the corporation the better the conditions of in-house housing systems were. According to a survey on employee benefits programmes, conducted by the Institute of Labour Administration in 2003 and 2004, the percentages of corporations which provided corporation-owned employee housing, leased employee housing and loans for housing purchase were 28 per cent, 75 per cent and 58 per cent respectively in the case of corporations with less than 1,000 employees, while the figures were as high as 78 per cent, 92 per cent and 97 per cent respectively in the case of corporations with 3,000 or more employees (Institute of Labour Administration, 2004).

People's aspirations for home ownership developed rapidly during the period of high-speed economic growth. Among the households who intended to improve their housing situation, the proportion of those who aimed at owning a house, which was 52 per cent in the Housing Situation Survey conducted in 1955, rose to 74 per cent and to as high as 90 per cent in the Housing Demand Surveys carried out in 1966 and 1969, respectively (Tamaki, 1974). Various factors accounted for the development of home ownership aspirations (see Miyake, 1979). There was a large disparity in the physical condition of housing between the owner-occupied sector and the rental sector. It was next to impossible, therefore, to obtain a good quality dwelling in the rental housing market. Even if it was a burden to purchase a house, as income increased steadily, repayments on the loan were expected to 
ease and the value of the house increase. The accumulation of an asset in the form of housing property was regarded as an effective means of securing the owner's livelihood in their old age.

Those who own mai homu could claim that they were core members of the mainstream society (Hirayama, 2003a). Aspirations towards home ownership had an impact, not only in the economic dimension, but also socio-culturally. An owner-occupied house was not only defined in a material sense but was also symbolic of the new social status and attitude of the owner. Home ownership was linked to a socially constructed image - a combination of middle or highlevel income, stable employment and credibility, and property asset ownership. Owning a home meant that the owner belonged to the core of society and owning a niwatsuki ikkodate jutaku symbolized that the owner had climbed up the ladder and reached the top.

The housing system, which focused on the production of owner-occupied housing, inevitably generated social inequalities. While families with middle incomes received more allocation of public funds to obtain good-quality housing, low-income renters were allotted fewer funds for the improvement of their housing conditions. There were also large disparities in in-house housing systems between major corporations and small or medium-sized corporations. Despite economic prosperity, many people were excluded from 'homeowner society' and suffered a form of 'housing poverty' (Hayakawa, 1979; Honma, 1980).

It is indeed necessary to pay close attention to the dynamic nature of housing inequalities. The housing system was a mechanism which provided many households with the potential or promise of access to middle-class society. Even if present housing conditions were poor, as long as they were better than previous housing conditions and there was the prospect of obtaining a good-quality house in the foreseeable future, it was not hard for households to put up with poor housing conditions, and this was endured as a 'temporary problem' in the life-course. The system that encouraged people to purchase housing was able to operate, despite the poor conditions and inequalities it generated, because it was supported by the majority of people who placed their hopes in the 'possibility' of becoming members of the 'homeowner society'. Many renters who aimed at purchasing a house regarded themselves as potential homeowners, and young people on low incomes, within the seniority system of wage augmentation and promotion, were able to expect an increase in income. In this context, the system, by means of encouraging people to join the 'housing ladder', could manipulate housing inequalities and frustration related to 'housing poverty'. There were people who did not have any 'possibility' of joining the 'social flow' toward middle-class society. Low-income households could not afford to purchase a home and employees in small companies without a seniority system could not expect a steady increase in income. However, as long as the economy continued to grow and the majority 
of people could climb up the ladder, social backlash over the home ownership oriented system was limited.

The 'feeling of middle-classness' expanded during the period of high-speed economic growth, with the popular phrase ichioku so churyu, meaning all 100 million of Japan's population (now around 126 million) regarded themselves as members of the middle class. Opinion polls regarding living standards, which have been conducted by the government since 1958, revealed that the proportion of those who saw the level of their living standards as 'middle' increased from 72 per cent in 1958 to 87 per cent in 1965, then exceeded 90 per cent in 1973 and remained at around 90 per cent until the end of the 1970s (see Figure 2.1). The rate of those who considered their living standard as 'middle of middle' was 37 per cent in 1958 and increased to around 60 per cent by the 1970s. Many scholars and commentators sought to account for this 'feeling of middle-classness'. Murakami (1984) stressed that the structure of social classes had collapsed with the rise of the 'affluent society' and instead a huge and homogeneous 'new middle mass' had emerged, while Kishimoto (1978), criticizing Murakami's argument, demonstrated that the hierarchical class structure had not disappeared and that the 'feeling of middle-classness' was just a social illusion. According to Imada (1989), there were no objective parameters to explain 'feelings of middle-classness' and people's feelings and material conditions were unrelated.

There has been no evidence-based analysis of the 'feeling of middle-classness' related to housing in this period. It is not unreasonable, however, to consider that the expansion of home ownership was an engine in the formation of 'feeling of middle-classness'. Owning a home, which represented housing stability, realization

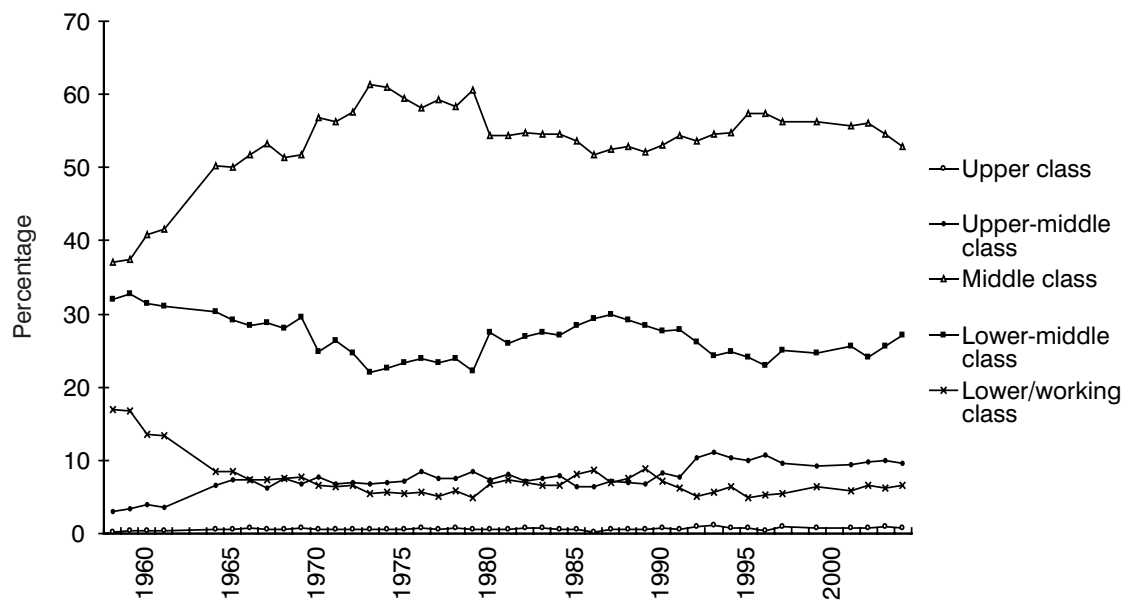

2.1 Self ranking of social class in Japan 1958-2004 Source: Cabinet Office, Public Opinion Survey. 
of a property asset and membership of mainstream society, fostered a sense of identification with the middle class. Even if a household was lower class, if they were able to expect to own a home in the future, they tended to regard themselves as a member of the middle class. The 'feeling of middle-classness' was born out of the expectation of change and improvement in living conditions rather than actual living standards experienced at a certain point in time. The housing system in forming a 'housing ladder' and 'social flow' supported the development of mass 'feeling of middle-classness' and managed social inequalities successfully.

\section{Residential property in an uncertain economy}

It was in the 1990s that the organization of the home ownership based housing system began to unravel due to the overall disintegration of conventional social and economic frameworks. In this section I begin to address understandings of the transformations in the housing system within the wider context of socioeconomic restructuring. The economic bubble was a key catalyst in reshaping the housing system. The bubble economy began with an abnormal rise in land and housing prices in the latter half of the 1980s and subsequently collapsed at the beginning of the 1990s. Since the bubble burst, owner-occupied housing has generated capital losses and residential property assets have been mired in a cycle of devaluation (Forrest et al., 2003; Hirayama, 2003b). From the end of the war to the end of the 1980s, Japanese economic growth had been deeply intertwined with the continuous rise in real estate values. This had been considered a "natural phenomenon' and operated as a capital gain based system. The sharp drop in land and housing prices after the bubble collapsed threw the Japanese economy into confusion and a long, deep recession (Oizumi, 1994).

Although the direct factor that caused the devaluation of residential properties was the bursting of the bubble, it is noticeable that the over-construction of owner-occupied housing further encouraged the drop in house prices. Housing construction was an engine for economic development in post-war Japan (see Oizumi, in this volume). With the first oil crisis in 1973 as a turning point, housing policy became a direct measure for the stimulation of the economy and the government put increasing importance on the expansion of GHLC loans. The GHLC launched a series of new systems to expand home ownership. The step repayment system, in which the amount of repayments was lowered for the first five years, began to operate in 1979 and a two-generational mortgage system, in which children took over their parents' mortgage, was established in 1980. Moreover, the provision of supplementary loans, which were added to basic loans, was implemented in 1985.

In the period during and since the bubble economy, the government has continuously engaged in the promotion of housing construction. In context of Japan-US trade friction, the production of owner-occupied dwellings was 
furiously promoted to increase domestic demand. The GHLC expanded the supply of mortgages and repeatedly improved its lending conditions. After the bubble collapsed, the government, in order to address economic downturn, further encouraged housing construction. In the first half of the 1990s, the total amount of residential loans provided by the GHLC increased to a record high and its lending conditions improved even more. Income tax deduction for home purchasers was also expanded in stages in the 1990s to stimulate the demand for home ownership.

Relentless aggressive policies aimed at accelerating mass construction of housing led to over-supply of owner-occupied dwellings, which amplified the post-bubble devaluation of residential properties. The post-war housing system, which was established in an era of housing shortage and of urbanization, aimed to fuel housing production in order to meet the huge demand for dwellings. As housing construction progressed and urbanization began to subside, however, an era of housing surplus began in the middle of the 1980s. Since the first half of 1970s, when the total number of dwellings exceeded that of households, the vacancy rate has risen, from 7.6 per cent in 1978 to 9.8 per cent in 1993, and to 12.2 per cent in 2003 . There remain numbers of substandard dwellings, and goodquality housing is still in short supply. In this context, the housing shortage has not been resolved. The facts are, however, that the quantity of housing is now more than sufficient and that vacancy rates are rising. Miyake (1991), having analysed the structure of demand for housing, called attention to the emergence of what he calls 'negative demand'. As his research showed, demand for a certain type of housing in a certain area could drop sharply, resulting in an increase in vacancies. The traditional housing system operated on the assumption that 'positive demand' for dwellings would be continuously generated. The expansion of 'negative demand' in the era of housing surplus, however, has begun to affect the housing market more significantly.

A watershed in the history of post-war housing policy is the abolition of the GHLC. The economic policy of the government has been traditionally Keynesian, and in this context the provision of GHLC mortgages was expanded in order to address the post-bubble recession. However, national finances have become trapped and government sector debts have risen to crisis levels. In the late 1990s, the government reoriented its economic policy radically towards the downsizing of the public sector and the deregulation of the market economy. In accordance with this policy shift, it was judged to be prudent to do away with the GHLC, which is a huge financial burden, and to enlarge and deregulate the private mortgage market (see Oizumi, in this volume). Private lending institutions, having suffered the post-bubble recession, have been calling for the expansion of the private housing loan market. Financing for housing purchase, which was supported by Keynesian style governance, is now expected to be met by the market. It remains to be seen what will come from the abolition of the GHLC. 
The extent of housing devaluation has been strongly differentiated between different types of dwelling (Hirayama, 2003b). In the 1980s when the economic bubble swelled, the prices of all types of owner-occupied housing rose at a similar rate. In the 1990s after the bubble collapsed, however, the rate at which housing prices fell differed greatly depending on the type of owner-occupied housing (see Figure 2.2). The fall was greater among second-hand housing than in newly built housing, and for condominiums rather than for single-family dwellings. In other words, the depreciation of second-hand condominiums has been marked, and the scale of capital losses generated on condominium properties is substantial. As illustrated in Figure 2.3, in the Tokyo metropolitan area, the average price

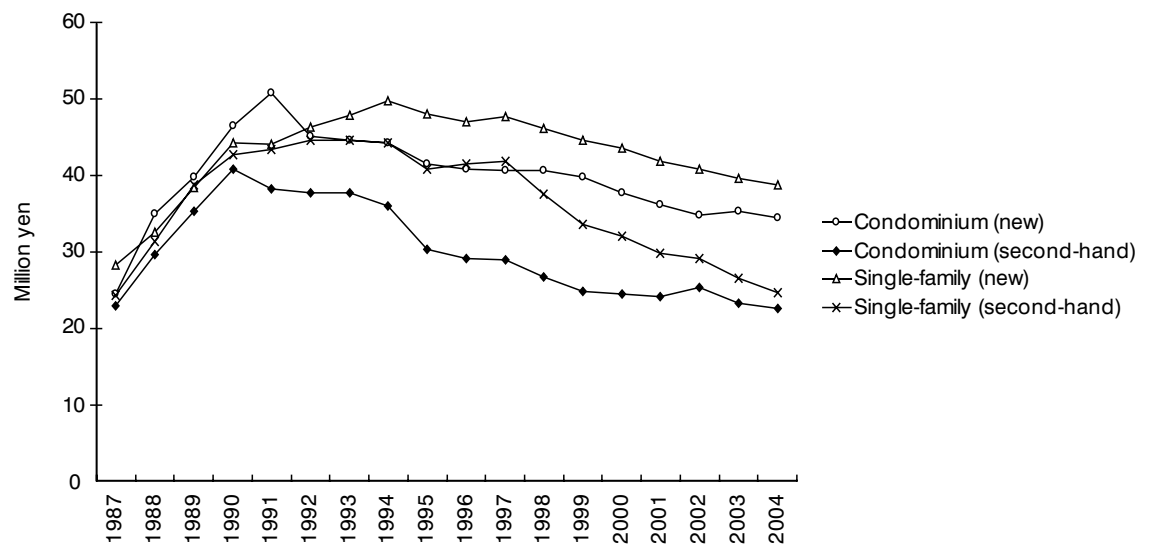

2.2 Nominal housing prices of homes with GHLC loans within a $70 \mathrm{~km}$ radius of Tokyo city

Source: Government Housing Loan Corporation.

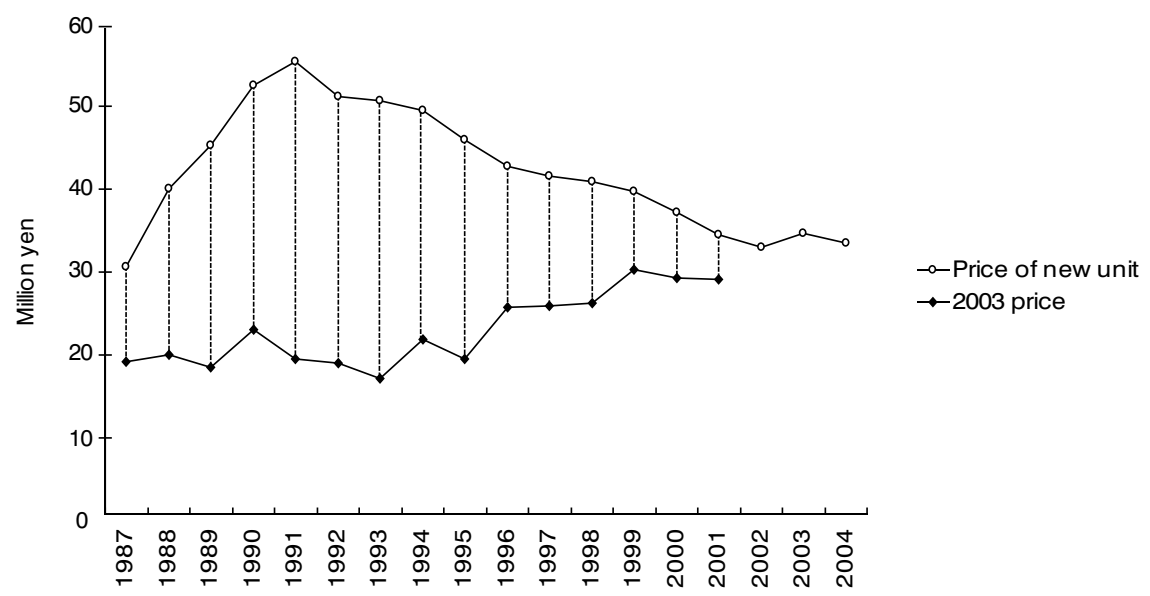

2.3 Capital loss on typical condominium unit of 70 square metres within a 70 $\mathrm{km}$ radius of Tokyo city

Source: Government Housing Loan Corporation. 
of a newly built condominium with a floor area of 70 square metres was $¥ 55.8$ million ( $£ 279,000$; $¥ 200=£ 1$ ) in 1991 . This fell to $¥ 19.1$ million $(£ 96,000)$ by 2003, generating a capital loss of $¥ 36.7$ million (£184,000). Households which purchased a condominium in the bubble peak have lost more than half of the value of their property asset.

The drop in the marketability of second-hand housing was further accelerated by institutional factors (Hirayama, 2005). Home ownership housing policy has provided advantages for the acquisition of new housing in order to promote housing construction. The repayment period for GHLC loan was longer for new housing than for second-hand housing, while the GHLC excluded the purchasers of dwellings over 25 years old. People also show a clear preference for new homes. According to the survey on 'Public Opinion on Housing' conducted by the government in 2004, to the question 'if you purchase a home, which do you prefer a new house or an older house', only 1.7 per cent of the respondents opted for second-hand housing but 66 per cent for new housing. As a comparative study on house price moves in Japan and Britain showed, while the patterns of price changes in new and old housing have been similar in Britain, price indices between new and old dwellings have greatly differed in Japan (Hirayama et al., 2003). This implies that weakness in marketability of older stock is peculiar to the nature of the Japanese housing market.

As the government has persistently placed importance on the expansion of housing construction and home ownership, Japanese homeowners are now deeply in debt. As shown in Figure 2.4, the total amount of outstanding housing loans swelled from $¥ 48.2$ trillion ( $£ 241$ billion) in the fiscal year 1980 to $¥ 191.5$ trillion ( $£ 958$ billion) in the fiscal year 2001 . The ratio of outstanding housing loans against GDP rose from 19.4 per cent to 38.2 per cent during the same period. Figure 2.5 shows the tendency of the rate of households with a debt for a residential loan to have increased. Particularly among households whose heads are 45-49 years old, the rate of those having liabilities on mortgages, which was approximately 20 per cent in 1970, rose to exceed 50 per cent in 2000. Since the late 1990s, while the outstanding residential loans of the GHLC have decreased, reflecting the policy of downsizing the public sector, that of private financial institutions has increased dramatically (see Figure 2.4). The mortgage market has increasingly become important for the banking sector. Major corporations since the 1980s have shifted their means of raising funds from intermediated financing by banks to equity financing. Accordingly, the banking sector, which has been losing quality corporations as loan destinations, has been engaged in exploiting the retail market of residential loans. In the 1990s when the recession deepened, the family budgets of households with housing loans deteriorated. The government promoted the acceleration of home purchase and expanded the mortgage market despite the increased instability of income and employment. As a result, the number of GHLC loans in default over six months increased from 3,340 to 46,582 between 1990 and 


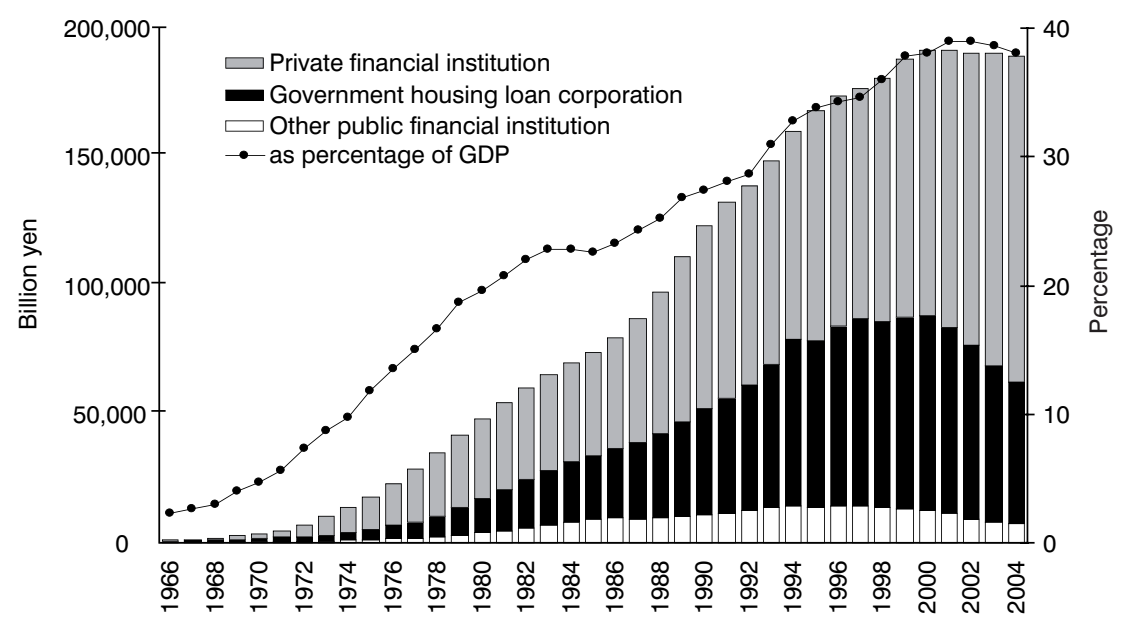

2.4 Outstanding mortgage debt as a percentage of GDP Source: Government Housing Loan Corporation.

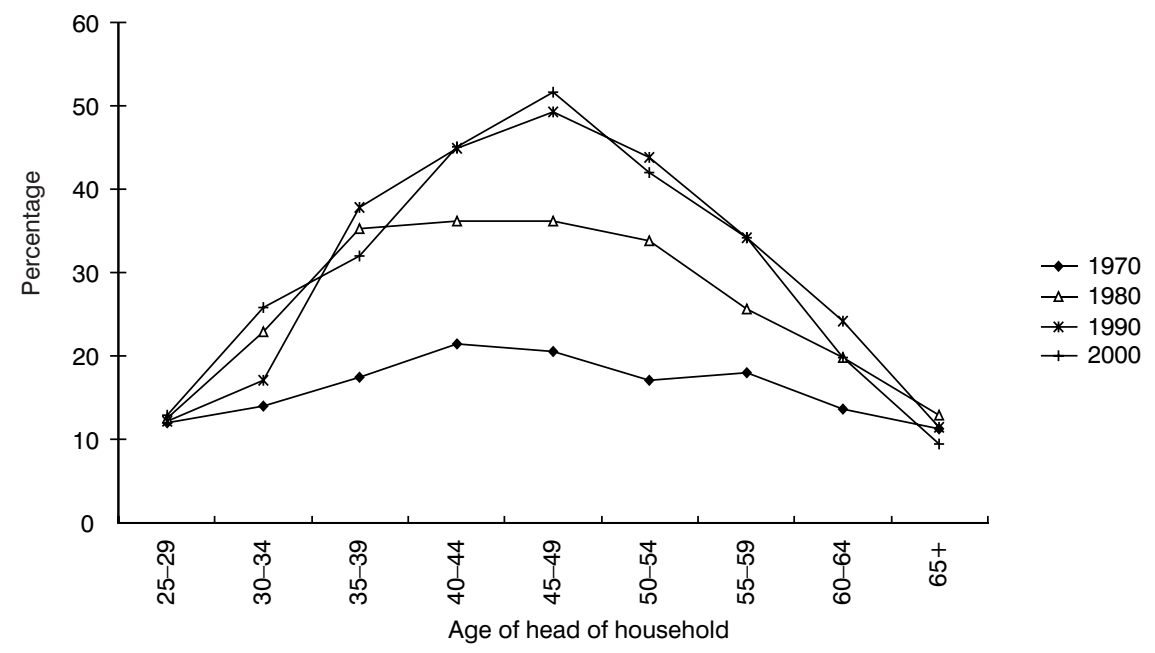

2.5 Ratio of households with debts on residential property Source: Statistics Bureau, Family Savings Survey.

2003. When a GHLC loan cannot be repaid, the Financial Security Association takes over the loan. The number of such cases increased from 4,820 in 1990 to 17,493 in 2003.

Together with the new conditions created by the volatile economy, the security of owning a house as an asset has been undermined. However, whether or not the 'homeowner society' will disintegrate is a different question. Despite the 
economic destabilization of housing property, there is some evidence that people's aspirations toward home ownership have not declined significantly. According to the Survey on People's Consciousness about Land Issues conducted by the Ministry of Land, Infrastructure and Transport (2004), though the ratio of those who answered that they want to own land and a house decreased from 88 per cent in 1996 to 82 per cent in 2003, the situation in which most people desire to own housing and land has not changed. An owner-occupied home in the post-bubble period is of new type with no promise of capital gains. The research showed that the proportion of those who agreed that land is a more secure asset than saving or stock dropped notably from 62 per cent in 1994 to 33 per cent in 2003. The number of people who purchase real estate expecting its market price to appreciate has decreased. However, the value of an owner-occupied dwelling is not comprised of only its value as an asset. The post-bubble demand for home ownership has been maintained by a desire for: a house of a relatively good quality; stable housing tenure with no fear of eviction; a controllable living space; and the representation of a social status. While the nature of home ownership cannot be stationary within an increasingly uncertain economy, the vitality of 'homeowner society' appears persistent.

\section{Differentiation of housing pathways}

The filtering system played a substantial role in generating a 'social flow' of people climbing up the 'housing ladder' to nurture the 'homeowner society'. The functioning of the system, however, has begun to unravel due to the reorganization of socio-economic conditions, and accordingly household pathways relating to housing and home ownership have progressively been differentiated. The filtering system is effective as long as middle-class society is stable and the majority of people can join the social mainstream. When the social core is destabilized, the 'ladder' sways and the 'flow' no longer runs smoothly. The focus of this section is on the differentiation in housing trajectories caused by the disintegration of the traditional filtering system.

The system in which home ownership and middle-class society reinforce each other has begun to fray. Since the 1990s, the persistent recession has undermined the living conditions of the middle class and social inequalities in terms of income distribution and employment stability have expanded. An increasing body of literature (see Sato, 2000; Tachibanaki, 1998) has provided substantial evidence of widening social disparities, which have played a role in drawing attention to the issue of social inequality. Although the 'feeling of middle-classness' is still persistent, there is a sign that the myth of ichioku so churyu is beginning to crumble. The proportion of those who regarded their living conditions as 'middle of middle', which was around 60 per cent in the 1970 s, dropped in the 1980s (see Figure 2.1). From the 1970s to the 1980s academic investigations 
into social class related themes declined substantially due to the unprecedented economic prosperity in which it was assumed that issues such as social inequality, unemployment and poverty would become marginal. Along with the prolonged economic recession, however, research on social classes and disparities has reemerged and intensified in the Japanese academic sphere since the late 1990s (see Higuchi, 2003; Otake, 2005; Shirahase, 2005).

The filtering system was based on the assumption that many people form a 'standard household' and live a 'standard life-course'. Household forms and lifecourses, however, have been diversifying and the composition of society has been fragmented (see Hinokidani, in this volume). A 'standard' family or life-course can no longer be standard in present-day Japan where: there is a high speed of social ageing; the fertility rate is rapidly dropping; the age at marriage is rising; more people remain unmarried; and the divorce rate is going up. Conventional family households have been decreasing, and instead single households, elderlyonly households and childless couples have been increasing. According to the Population Census, from 1970 to 2000, the proportion of nuclear households with children dropped from 46.1 per cent to 32.8 per cent while that of single households rose from 10.8 per cent to 25.6 per cent. This tendency is more noticeable in urban areas, particularly big cities.

Cohort effects in the differentiation of housing pathways have become notable. This has been reflected on the tendency of home ownership levels to drop particularly among young households (see Figure 2.6). An increase in single households and couples without children among the younger generation has been a factor in the delay in entering the home ownership market. The young cohorts have also been particularly affected by the recession and have experienced increased instability

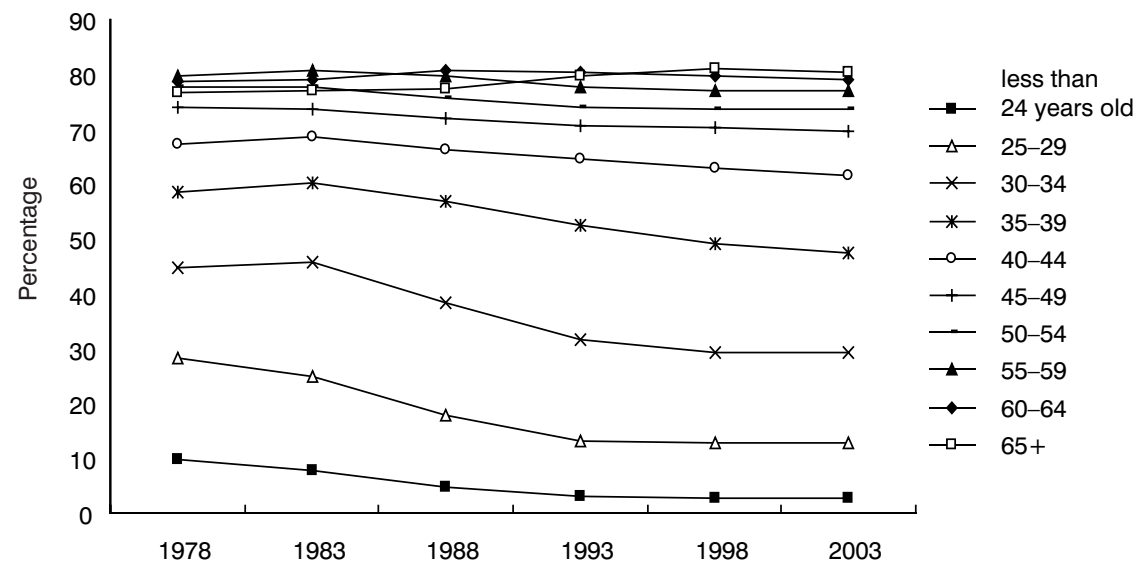

2.6 Home ownership rate by age Source: Statistics Bureau, Housing Survey of Japan and Housing and Land Survey of Japan. 
in employment and income, which has also caused the drop in the levels of home ownership. Since the latter half of the 1990s, an increase in the number of young people who are in neither employment, education or training has been regarded as a new social problem. It is apparent that the young generation is not following the life-course of the previous generations.

The extent of the impact caused by the rise and fall of the economic bubble on the asset value of owner-occupied housing is differentiated between cohorts. Shifts in the rate of home ownership by age cohort between 1988 and 1993, which marks the peak of the bubble, are shown in Table 2.2. Households who purchased a house in this period have experienced a serious devaluation of their properties. Baby-boomers who were born between 1947 and 1949 have followed a life-course that has clearly reflected the social and economic changes in post-war Japan. In the cohort of those who were born in the period 1944-8, which includes many of the baby-boomers, the rate of home ownership reached 66.2 per cent by 1988 , then increased by only 4.2 per cent to 70.4 per cent in 1993 . This implies that the majority of the baby-boomer households had purchased a house before housing prices peaked and that, though they have experienced a devaluation of their property assets, the extent of the fall has been relatively small. By comparison, for the cohort of those who were born in the period 1954-8, which immediately followed the baby-boomer generation, the rate of home ownership between 1988 and 1993 increased by 13.8 per cent from 38.4 per cent to 52.2 per cent. It is clear that many households in this cohort have experienced a substantial loss in the value of their housing assets.

The rise and fall of the bubble caused tremendous fluctuations in house prices. It is, however, not only the economic bubble, but also the moves of the baby-boomer generation households up the housing ladder that encouraged the volatility of the housing market (Miyake, 1991). Many baby-boomers entered the

Table 2.2 Home ownership rate by age cohort between 1988 and 1993

\begin{tabular}{|c|c|c|c|c|c|}
\hline \multirow[t]{2}{*}{ Birth year } & \multicolumn{2}{|c|}{$\begin{array}{l}\text { Home ownership } \\
\text { rate as of } 1988 \text { (age) }\end{array}$} & \multicolumn{2}{|c|}{$\begin{array}{l}\text { Home ownership rate } \\
\text { as of } 1993 \text { (age) }\end{array}$} & \multirow{2}{*}{$\begin{array}{l}\text { Rate of } \\
\text { increase } \\
1988-93 \\
B-A\end{array}$} \\
\hline & & $A$ & & $B$ & \\
\hline 1959-63 & $17.9 \%$ & $(25-29)$ & $31.7 \%$ & $(30-34)$ & $13.8 \%$ \\
\hline $1954-58$ & $38.4 \%$ & $(30-34)$ & $52.2 \%$ & $(35-39)$ & $13.8 \%$ \\
\hline 1949-53 & $56.8 \%$ & $(35-39)$ & $64.5 \%$ & $(40-44)$ & $7.7 \%$ \\
\hline $1944-48$ & $66.2 \%$ & $(40-44)$ & $70.4 \%$ & $(45-49)$ & $4.2 \%$ \\
\hline 1939-43 & $72.0 \%$ & $(45-49)$ & $74.0 \%$ & $(50-54)$ & $2.0 \%$ \\
\hline $1934-38$ & $75.4 \%$ & $(50-54)$ & $77.4 \%$ & $(55-59)$ & $2.0 \%$ \\
\hline
\end{tabular}

Source: Statistics Bureau, Housing Survey of Japan. 
home ownership market by the early 1980s and produced a large-scale 'positive demand' for dwellings, which triggered the subsequent rise of house prices. By the early 1990s many baby-boomers had become homeowners and house prices began to drop. Essentially, the satiation of baby-boomer home ownership demand led to growing 'negative demand' in the owner-occupied housing market. The generation following the baby-boomer generation were thus pressed into purchasing houses at higher prices, resulting from the market boom brought on by the baby-boomers, and then experienced rapid devaluation of their housing properties in the post-bubble climate.

The filtering system, which has been reinforced by housing policy, will be affected by the dissolution of the GHLC. Compared with the GHLC, private banks set narrower qualifications in regard to repayment capacity and credibility for borrowing. The abolition of the GHLC means that it becomes difficult for low-income households, workers for small-sized companies and self-employed people to procure a mortgage to purchase a house. The GHLC, which provided long-term mortgages of fixed low-interest mortgages, mitigated the influence of the volatile capital market on borrowers. It is not certain whether or not future bank loan conditions will be the same as those of GHLC loans. The 'company society', which has supported the filtering system, has weakened due to the prolonged recession and a more competitive business environment. An increasing number of corporations have been abandoning the conventional system of lifelong employment and introducing a performance-based system to replace the seniority system for wages and promotion. There has been an increase in short-term contract employees, part-time workers and temporary employees. It is not clear whether or not the in-house housing systems implemented by corporations will be maintained. Some surveys have shown that more companies have begun to unload their properties of employee housing and to abolish internal housing-related systems (Japan Institute of Life Insurance, 2003; Research Institute of Employee Benefits, 2003). Baby-boomers climbed up the housing ladder, supported by low-interest GHLC mortgages and the employee benefit programmes of corporations. Younger generations, however, will not be provided the level of support that was given by the GHLC and the 'company society' in becoming members of the 'homeowner society'. They are required to ascend the housing ladder by themselves under more competitive market conditions.

The change in the pattern of housing tenure related to household moves, as shown in Figure 2.7, implies that the filtering system has become dysfunctional in terms of the promotion of home ownership. Throughout the 1980s, when the bubble economy developed, the number of moves from rental housing to owneroccupied housing dropped sharply and moves in the opposite direction from an owner-occupied house to rental house increased. This tendency signifies that the extraordinary rise in house prices reduced the number of first-time homebuyers and made it financially difficult to maintain owner-occupied tenure. After the 


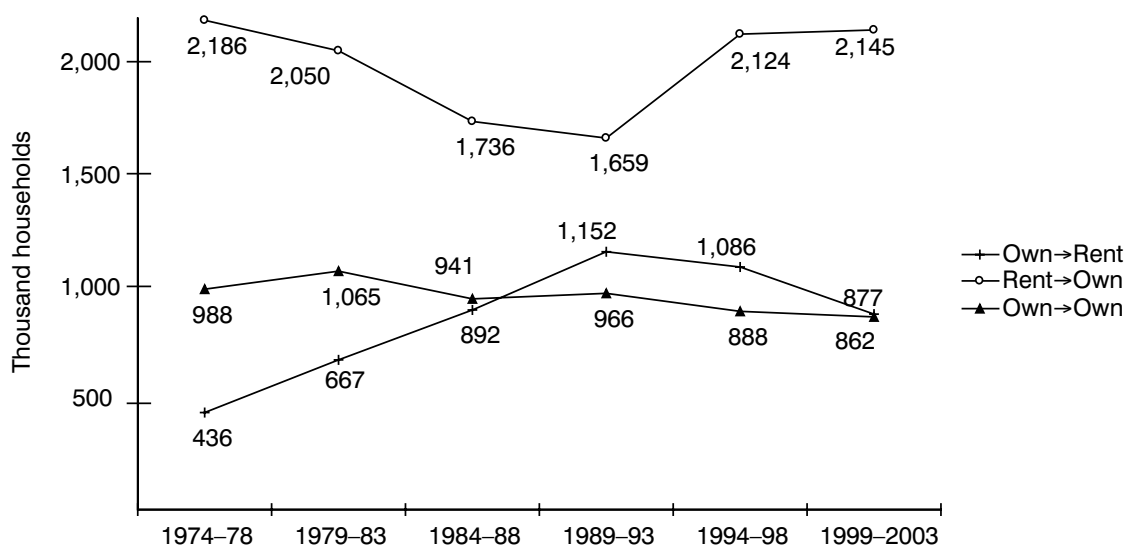

2.7 Household moves and tenure change

Source: Statistics Bureau, Housing Survey of Japan and Housing and Land Survey of Japan.

bubble collapsed, first-time homebuyers increased due to the drop in house prices and the entry of baby-boomers' children as a large cohort into the home ownership market, and moves from owner-occupied housing to rental housing decreased. On the other hand, moves within the owner-occupied sector continued to gradually decrease even after the bubble burst. The main reason is that households who purchased a condominium during the bubble period became tied down by a capital loss. It has become difficult for them to sell and move out of their condominiums. While capital gains fuelled the filtering system, capital losses effectively clogged the filter.

A new phenomenon for the housing system, which should be noted, is an agglomeration of a huge housing stock. The continued mass construction of housing throughout the post-war period resulted in more than a doubling of the total number of dwellings from 20 million in 1963 to 47 million in 2003 (see Table 2.1). A massively swollen housing stock is a new factor that further differentiates household trajectories in relation to housing.

An increasing number of younger people are expected to inherit housing assets which their parents' generation accumulated (see Izuhara, in this volume). A high rate of home ownership in the parents' generation combined with a decreasing fertility means a rise in the possibility for the next generation to inherit residential properties. On the one hand, the increased probability of housing inheritance is likely to weaken the propensity of the following generation towards house purchase. Younger households have the option to wait to inherit their parents' housing instead of purchasing a home with the burden of loan repayment. Older households also maintain home ownership partly in order to bequeath a property asset to their children. According to the Survey on People's Consciousness about 
Land Issues in 2003, approximately a half of respondents who wished to own land and housing expressed the intention to leave an asset for their offspring as a reason why they wanted to own a real estate property (Ministry of Land, Infrastructure and Transport, 2004). On the other hand, however, the next generation is often inclined to purchase their own housing rather than waiting to inherit, because expanding longevity tends to delay succession, and also the location of parents' homes is not necessarily desirable for the offspring. A survey of 4,914 households conducted by the Postal Services Research Institute in 2004 revealed that 14.1 per cent of the respondents had inherited residential real estate. While this figure becomes higher as the respondents get older -17.5 per cent in their 50 s, 21.1 per cent in their $60 \mathrm{~s}$ and 23.8 per cent in their $70 \mathrm{~s}-$ it is as low as 9.1 per cent in their 40s and 2.7 per cent in their 30s (Postal Services Research Institute, 2005). This implies that most offspring households are not likely to inherit housing property in their 30s and 40s when they begin to need or desire an owner-occupied home.

In addition to the effects of inheritance, there are some households who own one or more additional residential property beside the home they live in. According to the Housing and Land Survey of 2003, 7.7 per cent of households had one or more additional dwellings. This proportion is higher for older people and for those whose income is high: 21.1 per cent of households with an annual income of $¥ 10$ million ( $£ 50,000$ ) or more and 11.3 per cent of households with its head aged 55 or older. Of all the additional dwellings, 42 per cent are occupied by the owner's relatives and 35 per cent are rented out. Although the number of households who own additional housing property is small, there is a possibility that the number of such households will increase. An increasing number of those households who purchase a house and then inherit their parents' home might utilize the housing surplus for rental income. Homeowners who move for various reasons, such as occupation-related reasons, might not dispose of their house due to the drop in housing prices but may rent it out instead. Omi et al. (1991), through their research on condominiums in various cities, found that a considerably high proportion of owners were not living in, but renting out their properties, suggesting the new tendency of condominiums to be utilized as an income source rather than an owner-occupied dwelling.

As housing stock augments further, the structure of social inequalities relating to housing wealth becomes more complex. Housing and asset conditions of young households in the future will be partly determined by whether or not their parents own a house and whether they can inherit it or not. Sonoda (2000), having analysed the possibility for urban renters to inherit housing, found that renters with relatively high incomes tend to have a good prospect of housing inheritance while most lowincome renters do not have any possibility of inheriting residential property. The implication is that social inequalities in terms of housing within a generation tend to be passed down to the next generation. As the number of houses increases to exceed that of households, households having secondary residential properties 
who can obtain rental income increase. It is not likely that the growing stock of housing is distributed evenly. While there will be an increasing number of families having considerable housing wealth, low-income renters whose parents are also renters will continue to be excluded from housing property based society.

\section{Urban fragmentation and the home ownership market}

In order to further develop understanding of transformations in the housing system, we should now explore the spatial fragmentation of the urban home ownership market as a new dynamic in the reorganization of housing conditions. That is to say, there has emerged a new, marked tendency in the home ownership markets of large cities to be divided into 'hot spots', where the housing market becomes increasingly active, and 'cold spots', where the market is persistently inactive (Hirayama, 2005). In response to the prolonged post-bubble recession, the government launched 'urban renaissance' as a key policy in the late 1990s with the aim of stimulating economic recovery. A series of measures such as the promotion of housing construction and urban redevelopment and the deregulation of urban planning has been vigorously put into practice (Igarashi and Ogawa, 2003). In the context of economic globalization, the government put particular emphasis on the restructuring of Tokyo as a global city (Machimura, 1992; Saito and Thornley, 2003). Until the 1980s, the housing system accelerated the mass construction of dwellings in tandem with the simple force of expanding urbanization. In the 1990s after pressures of urbanization were subdued, however, the combination of the 'urban renaissance' policy, to promote housing construction, and the protracted recession began to spatially differentiate patterns of growth and decline in the housing market, creating a novel context for home ownership.

In the central areas of large cities, particularly Tokyo, new hot spots have been generated by the construction of condominiums. In the post-bubble period, it has become possible to construct residential buildings in central city areas as land prices have decreased. With the persistent recession, many enterprises have begun to dispose of large tracts of land, which are now being utilized for new condominium developments (Ministry of Land, Infrastructure and Transport, 2003). The increased provision of new condominiums in the city centres has stimulated the so-called 'back to the city' movements. In the big cities, where an increase in suburban populations and a decline in the population of the inner-city areas had been the conventional pattern, population flow to city centres reasserted itself in the latter half of the 1990s.

A construction boom of condominium towers of over 20 storeys reflected and reinforced the appearance of the hot spots in the Tokyo metropolitan area (Hirayama, 2005). According to a survey by the Real Estate Economic Institute, in the greater Tokyo region, which includes the prefectures of Tokyo, Kanagawa, Chiba and Saitama, 137 condominium towers or 35,697 units were completed. 
New starts of high-rise housing are expected to increase further. As of January 2003,336 condominium towers with 109,181 units were planned to be built in the Tokyo region (see Figure 2.8). A condominium tower block forms a fortress-like 'vertical enclave'. Not only does it create an economic and social differentiation of space, but it is also symbolic of the fragmentation of urban space. A large-scale building complex is horizontally cut off from its neighbourhood and its higher floors are vertically segregated from the ground level. The complex produces a closed and self-contained space in itself. Within the complex, residents are provided with hotel-like services and have access to various facilities such as a fitness room, a relaxation room, a party room and retail shops. The security systems to protect the complex are tight and each building is equipped with many surveillance cameras. Common-use areas like stairs and corridors, which were open to the outside air in traditional multi-family residential buildings, are enclosed within buildings in the newer towered condominium blocks. The architectural profile of the 'vertical enclave' is totally alien to its vicinity, and those dwelling in it rarely have contact with the residents of the surrounding neighbourhood, which contrasts starkly with the historically integrated neighbourhood focus of Japanese residential development.

Developers used to build housing targeting the nuclear family as the 'standard household'. Associated with the diversification of household types, however, conventional nuclear families have decreased and small households such as single-person and couple-only households have increased. It has, therefore, become necessary for housing developers not only to target family households

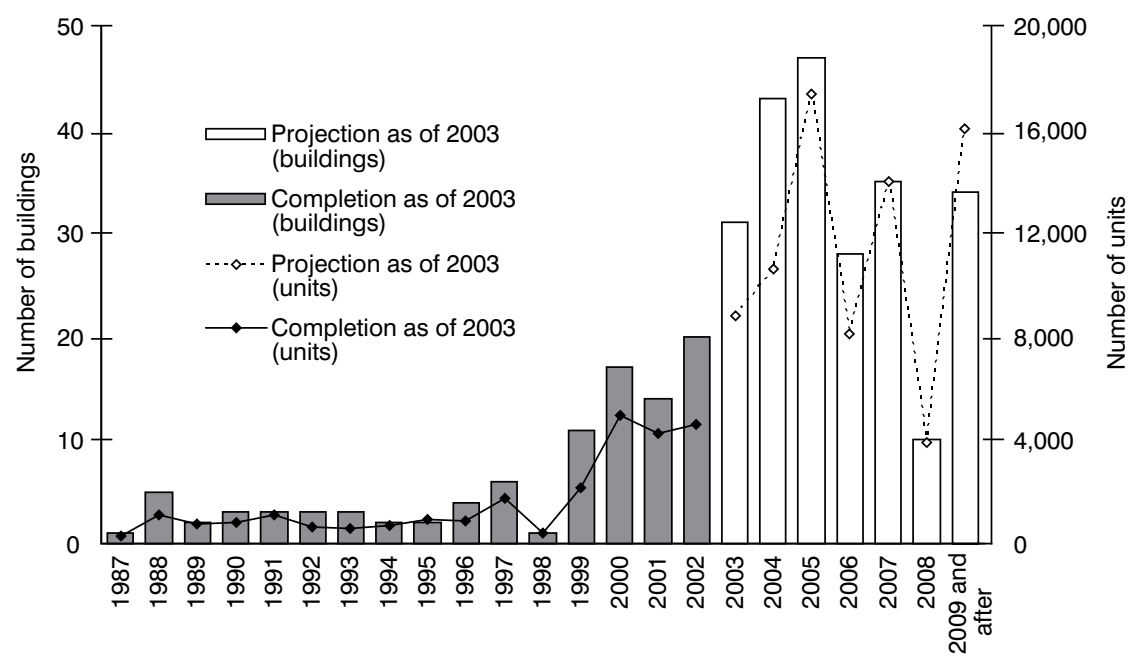

2.8 Completions and projected completions of tower condominiums, Tokyo Source: Real Estate Economic Institute Co. Ltd. 
but also to stimulate the housing market by providing various households with diverse housing types. Developers have begun to provide new types of housing for singles and couples. One type, which has been increasing in number, is a compact condominium unit with a floor space of just 30-50 square metres. Another type is a SOHO (Small Office Home Office), which is a combination of a small office and a small living space for small households, designed for workers in the information sector among others. The tendency of household size to become smaller is more noticeable in the central city areas. A survey of 3,743 households who purchased a condominium in the Tokyo metropolitan area in 2004 revealed that more single people and less nuclear households acquired a condominium in the ward-districts than in other areas. The ratios of singles and nuclear households were 22 per cent and 34 per cent in the ward-districts, and 9 per cent and 51 per cent in other, less central areas, respectively (Recruit, 2005).

One tendency in the housing market in the central areas of large cities is that an increasing number of single women are acquiring condominiums. The level of home ownership is lower among female-headed households than among male-headed households. Among single people aged 40 or older, however, the home ownership rate of women is higher than that of men. Matsumoto (1998), analysing the geographic distribution of single people who own a house in the Tokyo metropolitan area, found that the ratio of female homeowners was high in central city areas while that of male homeowners was high in the periphery areas, implying an expansion of the home ownership market for single women in the city centre. Yui (2004), investigating the condominium market, identified the formation of a structure that supported the growing market for single women that involved: an increase in income of working women combined with a drop in housing prices; the tendency of single women to put importance on convenient commuting leading to the growth of a female condominium market in city centres; single women, being concerned with providing for their old age, increasingly desiring to stabilize their residential situation and acquire an asset in the form of a dwelling; and lastly, developers increasingly seeking to expand the housing market by targeting single women as a new group of purchasers.

A consequence of the strategies of developers selling tower-type condominiums is the differentiation of the housing market not only horizontally but also vertically. The higher the floor on which a dwelling is located, the higher the price becomes. There are relatively low-priced dwellings on lower floors, which are for those in the moderate and middle-income bracket. Dwellings on the top floors are for households on high incomes, and on the very top floor, extremely expensive, luxurious dwellings for the very rich can be found. The vertical differentiation of dwellings in a condominium tower is more noticeable in high-class residential districts than in ordinary neighbourhoods. In the case of a 34-storey tower-type condominium with 314 units built in 2003 in Aoyama, one of the most fashionable districts in Tokyo, the differentials of housing size and price are vertically 
distinguishable (see Figure 2.9). On the ninth floor or below, the floor area of a dwelling is $45-99$ square metres and the price of a unit up to $¥ 130$ million, while, for most of the dwellings on the twenty-fourth floor and above, the floor area of a unit is 120 square metres or more and the price of a unit is $¥ 100$ million at the lowest. A unit on the top floor of 240 square metres was sold in 2003 for $¥ 710$ million ( $£ 3.55$ million). Figure 2.10 indicates the average price per square metre of dwellings by floor for 22 condominiums tower blocks built after November 2002 in Tokyo. The data demonstrate that housing prices are differentiated more in 'the housing market in the sky' than in 'the market at the ground level'.

Cold spots have been formed mainly in the suburbs and the outskirts of cities, where housing prices have been continuously declining and the housing market
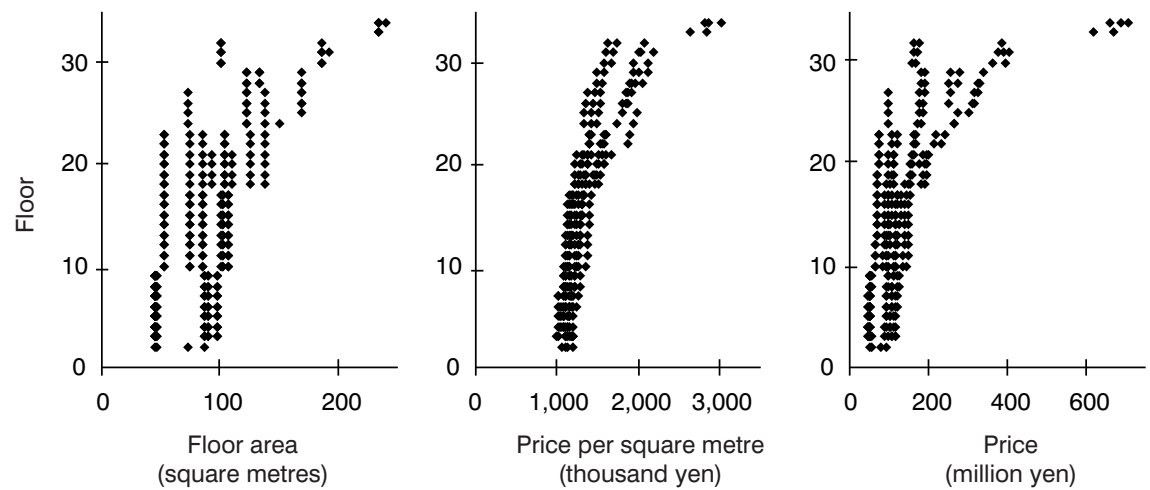

2.9 Floor area, price per square metre and a price of a unit, Aoyama Park Tower

Source: Advertising materials.

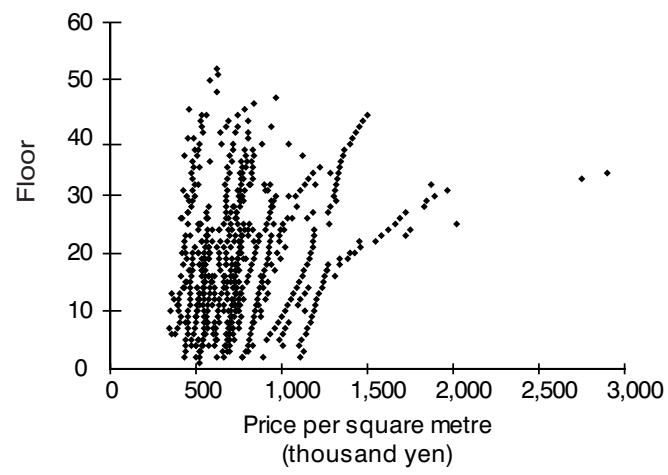

2.10 Price per square metre, by floor number of condominium units among the 22 case-study tower developments in Tokyo

Source: Advertising materials. 
has remained stagnant. It was not only the bursting of the bubble but also the formation of the hot spots themselves that produced the cold spots. The "urban renaissance' policy stimulated the construction of condominium blocks in the city centres, and consequently, the intensification of the 'back to the city' movements, which led to an inevitable decline in demand for housing in the suburbs and the urban peripheries. In this sense, the appearances of hot and cold spots in the urban home ownership market are linked to each other, and the new housing market boom in the hot spots has been created at the expense of the cold spots.

Households who purchased a condominium in the bubble period have suffered the sharp devaluation of residential property. There are two kinds of 'bubble condominiums': 'super-luxury condominiums' and 'suburban bubble condominiums' (Hirayama, 2005). Super-luxury condominiums were built in city centres and high-class residential districts in the latter half of the 1980s and purchased by the rich. Their extremely high price dropped drastically when the bubble burst. Although the quantity of super-luxury condominiums is relatively low, that of suburban bubble condominiums is high. Households that move to the suburbs generally desire single-family houses. During the bubble period, however, families with moderate and middle incomes bought condominiums in the suburbs, as housing prices had risen so dramatically. The marketability of a condominium unit of this type nose-dived in the post-bubble period. Households who bought a suburban condominium are now repaying massive amounts on the loans for their housing, which is rapidly declining in value. Moreover, the floor area of a condominium is generally smaller than that of a single-family house. As Matsumoto (2002) pointed out, the difference in floor area between a condominium and a single-family home is greater in the suburbs than in the city centres, which further pulls down the marketability of a condominium in the suburbs.

Some single-family housing estates in the suburbs, if not all, are expected to experience further decline (Kadono, 2000). As the movement of 'back to the city' progresses, the suburbs inevitably compete with each other and a drop in the marketability of residential estates, which were developed in unpopular places, is unavoidable. It has been assumed that Japanese people, historically and culturally, prefer single-family detached housing to multi-family housing. There is a new tendency, however, for younger generation households not necessarily to prefer living in single-family housing, which potentially reduces the demand for suburban houses. According to a survey on housing preferences carried out by the government in 2004, the ratios of respondents who prefer single-family housing were 85.5 per cent for those aged 60 or more and 60.8 per cent for those aged 20-9 (Ministry of Land, Infrastructure and Transport, 2005). During the bubble period, development of so-called 'ultra-distant suburbs' occurred, since the provision of owner-occupied housing, affordable for moderate-income households, was possible only in places which were extraordinarily distant from city centres. In the post-bubble period, many houses in the 'ultra-distant suburbs' remained 
unsold and the prices of such properties dropped sharply. A suburban niwatsuki ikkodate jutaku used to be a mai homu located at the top of the 'housing ladder', and represented inclusion in mainstream society. Many people who tried to climb up the ladder towards single-family housing in the bubble period were forced to move to the 'ultra-distant suburbs'. A house they are living in now no longer represents the top of the ladder.

\section{De-socializing the housing system}

The reorientation of housing policy by the government as well as socio-economic reorganization have reflected and accelerated the transformation of the housing system. This last section addresses the changing role of the government in managing the production and consumption of housing. The government took the initiative in structuring the post-war housing system. The basic course of housing policy has been laid out by Five-Year Housing Construction Plans, which the government has drawn up periodically since 1966 based on the Housing Construction Plan Act. Since the middle of the 1990s, however, the government has explicitly shifted its housing policy towards emphasizing the role of market mechanisms. The traditional 'three pillars' of housing policy have been dissolved and the policy principle of expanding the market-based provision of housing and mortgages has clearly been announced. The 1995 report by the Housing and Land Committee, which set out the basic orientation of housing policy, declared, 'Housing services should be consumed privately. In principle it should be left to the individual to determine what standard of housing should be enjoyed and what amount of expenditure should be spent for housing', stressing the necessity of 'utilizing the free market more widely' (Housing and Land Committee, 1995). In a subsequent report in 2000, the committee emphasized a 'market-driven direction' for housing based on the 'principle that housing and land should be acquired and utilized by individuals' own efforts' (Housing and Land Committee, 2000). The Housing Construction Plan Act was discontinued in 2006 and instead a new basic act for a new housing system was legislated. The new legislative framework of housing policy made the market its principal agent even more explicitly (Housing Bureau of the Ministry of Land, Infrastructure and Transport, 2004; Sectional Committee on Housing and Land of the Panel on Infrastructure Development, 2003, 2004).

De-socialization of the housing system has begun to progress, associated with the weakening of the government's control over the processes of housing provision. The global diffusion of so-called neo-liberal ideology clearly affected the reorientation of housing policy in Japan. The government has, in order to rationalize the downsizing of its housing policy, often referred to the tendency of governments in other countries, particularly Anglo-Saxon societies such as the US and Britain, to liberalize the economy. On the other hand, however, it is also important to look at the indigenous housing context in understanding 
shifts in Japanese housing policy. In the era of housing shortage, 'housing poverty' was regarded as a social problem and was prioritized as a political issue. Housing policy was given the clear purpose of facilitating the large-scale production of dwellings. In relation to the Five-Year Housing Construction Plan, a luminous and pressing goal was posted every five years - the goal set in 1966 was that 'one dwelling for every household' was to be ensured; the one set in 1971 was that 'one room for everyone' was to be secured; and the one set in 1976 was that 'the elimination of substandard housing' was to be achieved. Households having housing difficulties were defined as those who lived in nonresidential buildings such as factories and warehouses, in other people's houses, in dilapidated housing or in overcrowded conditions where, for example, four or more members lived in a space of less than 20 square metres. Such definitions, which reflected the severe condition of 'housing poverty', were used until the middle of the 1970s. The necessity of government intervention in the housing system was never doubted in the period when dwellings were desperately needed. Since the 1980s, however, with an expansion of a housing surplus and in context of increasing vacancies, the goal of housing policy has become less clear and its ground has been increasingly unstable. In the late 1980s the proportion of households living in substandard housing fell to less than 10 per cent, and therefore, it became difficult to stress the necessity of large-scale housing policy as a means to resolve this problem. Although 'housing poverty' has been persistent, its magnitude as a social and political issue has been lessened. The housing surplus played a role in undermining the traditional basis on which the government interferes in housing issues.

People's need for housing has become more diversified, which has also promoted the retreat of the government from housing policy. Household formation and life-courses have been de-standardized and housing pathways have become increasingly differentiated. People's housing conditions are fragmenting and relentlessly shifting, depending on various factors such as the stability of income and employment, household type, the timing of housing acquisition and the balance of asset and debt. A change in the housing sphere can be good news for certain groups and simultaneously bad news for others. A drop in housing prices works in favour of tenants who wish to purchase a home while it means the devaluation of housing assets for those who have already purchased a house. The economic condition of home ownership has progressively differed between 'hot spots' and 'cold spots', between those who purchased a dwelling before the bubble occurred and those who purchased a dwelling at the peak of the bubble, and between the outright owners of a house and owner-occupiers of a mortgaged house. The government once formed housing policy measures in order to address homogeneous and serious mass problems. When the housing conditions diversified and fragmented, however, the extent to which the government controlled the housing system began to decrease. 'Free choice' and 'individual consumption' 
have become key phrases in policy documents concerned with the reorganization of housing policy. Housing issues, which used to be located in the social sphere, have now been relocated into the private sphere and the government has increasingly entrusted housing to the choices of individual households.

As regards low-income housing, the government has launched a policy to provide a safety net for people with housing difficulties. The public housing system is expected to play a role as the core of the safety net policy. In circumstances where the provision of housing by market mechanisms is considered a principle, however, the formation of the safety net is defined as a residual measure and its target becomes as narrow as possible. New starts of public housing have stopped almost completely and only a small number of places can be provided for lowincome households.

The government used to take level of income as the main criterion to define qualification for entry into public housing. However, the target of the new safety net policy is defined not only by income level, but also by a set of 'welfare categories'. There has been an increasing tendency in the low-income housing system to screen people who qualify for public housing by using welfare categories such as 'the elderly', 'single mother households' and 'those with disabilities'. In addition to these 'traditional categories', 'new categories' such as 'homeless people', 'victims of domestic violence', 'crime victims' and 'households with infants' have been introduced to redefine the target of the safety net. Emphasizing such categories in the definition of potential public housing tenants implies that it has become difficult for those who are 'merely low-income' to move into public housing, which leads to greater justification for decreasing the provision of public housing. The policy to expand market housing and the safety net policy based on welfare categories are two sides of the same coin. Only a limited number of households who fit into the welfare categories are allowed to receive assistance from the government while others are in principle expected to secure their housing through the market.

The introduction of the welfare categories into the safety net system encourages the de-socialization of housing problems even more, as housing issues are technically analysed according to categories and special measures for each category are divisively defined. There are various issues such as housing renovation for people with disabilities, housing provision for the homeless, the supply of mortgages for the elderly and ensuring shelter for victims of domestic violence. However, these segmented housing issues are not regarded as social or political priorities but as residual and technical matters. Although the government admits the need to address problems for people with housing difficulties, the construction of a safety net is considered a technical challenge for marginal problems. 


\section{Conclusion}

In this chapter I have explored the process of transformation in the housing system in order to demonstrate how pivotal home ownership has been as a catalyst in socioeconomic change. The housing system in post-war Japan, by expanding middleclass home ownership, generated a clear orientation for both households and society. The aggregation of people's moves up the 'housing ladder' towards home ownership dynamically formulated a 'social flow', which enlarged and maintained a middle-class society. Home ownership played a central role in determining life-courses and forming the mainstream of society. From the last decade of the twentieth century to the beginning of the twenty-first century, however, the conditions of home ownership have been transformed by the increased instability of housing property as an asset; the differentiation of housing pathways; and the spatial fragmentation of the urban housing market. The government has begun to focus on the functioning of a more deregulated market in providing and financing housing. Indeed, the home ownership based housing system has functioned as an instrument to shape and reshape the socio-economic order in post-war Japan.

Over the past two decades the housing system has increasingly been embedded in the wider economy and social structure, and the interaction of home ownership and socio-economic transformations deepened further. This interaction produced a cycle in which social and economic changes and the home ownership system destabilized each other. Economic volatility has affected the price and asset value of housing, and the expansion of the mortgage market has had a profound effect on the condition of the broader financial market. The housing market has been fragmented into various sub-markets due to the diversification of household formation and life-courses, and the composition of the sub-markets is continuously shifting. Instability of income and employment has further undermined the housing trajectories of households.

The era when the economy was considered relatively predictable along with a clear social orientation has come to an end, and a new era of risk has become increasingly apparent (Tachibanaki, 2004). The extent to which the government and the 'company society' can protect the middle class in a planned way has been decreasing while the sphere encompassed by market forces has been expanding. The government has begun to emphasize 'free choice' and 'individual consumption' in reshaping the housing system. The increase of 'free choice' in 'individual consumption' of housing, however, means an increase in risks for individuals and potential for growing debt. When a household chooses a variable rate mortgage, there is the possibility that the interest rate will rise. If the asset value of a home purchased by an individual drops, the purchaser is accountable and liable for losses. As the housing system is de-socialized, individuals are increasingly expected to form their own housing path using their own resources within the market and to individually deal with various risks related to housing. The movements of individuals up individualized housing ladders will not lead to 
the construction of a social flow. The transitional conditions of the housing system and home ownership reflect and reinforce each other in complex ways, and the emerging landscape is of an unstable economy and a progressively fragmented society. The future of Japan is becoming uncertain. What is certain, however, is that housing and home ownership will play a more significant part in provoking socio-economic changes.

\section{References}

Forrest, R., Kennett, P. and Izuhara, M. (2003) Home ownership and economic change in Japan, Housing Studies, 18(3): 277-93.

Harada, S. (1985) Sengo jutaku housei no seiritsu katei (The establishment process of housing laws in post-war Japan), in Institute of Social Science, Tokyo University (ed.) Fukushi Kokka, vol. 6, Nihon no Shakai to Fukushi (The Welfare State, vol. 6, Japanese Society and Welfare), Tokyo: Tokyo University Press, pp. 317-96.

Hayakawa, K. (1979) Jutaku Binbo Monogatari (The Story of Housing Poverty), Tokyo: Iwanami Shoten.

Hayakawa, K. (2002) Japan, in M.A. Agus, J. Doling and D. Lee (eds) Housing Policy Systems in South and East Asia, Basingstoke: Palgrave Macmillan, pp. 20-37.

Hayakawa, K. and Ohmoto, K. (1988) Toshi jutaku mondai shi gaisetsu (The history of the urban housing question), in Tokyo Shisei Chosa Kai (Tokyo Institute for Municipal Research) (ed.) Toshi Mondai no Kiseki to Tenbo (History and Perspectives of Urban Questions), Tokyo: Gyosei, pp. 233-76.

Higuchi, Y. (ed.) (2003) Nihon no Shotoku Kakusa to Shakai Kaiso (Income Disparity and Social Class in Japan), Tokyo: Nihon Hyoron Sha.

Hirayama, Y. (2003a) Housing policy and social inequality in Japan, in M. Izuhara (ed.) Comparing Social Policies: Exploring New Perspectives in Britain and Japan, Bristol: Polity Press, pp.151-71.

Hirayama, Y. (2003b) Home ownership in an unstable world: the case of Japan, in R. Forrest and J. Lee (eds) Housing and Social Change: East-West Perspectives, London: Routledge, pp. 140-61.

Hirayama, Y. (2005) Running hot and cold in the urban home ownership market: the experience of Japan's major cities, Journal of Housing and the Built Environment, 20(1): 1-20.

Hirayama, Y., Forrest, R., Hinokidani, M, Izuhara, M. and Kennet, P. (2003) Restructuring of the home ownership system in Japan and Britain, Housing Research Foundation Annual Report, 29: 229-40.

Honma, Y. (1980) Mai Homu Gemu (My Home Game), Tokyo: Otsuki Shoten.

Housing and Land Committee (1995) Jutaku Takuchi Shingikai Toshin: 21 Seiki ni Muketa Jutaku Takuchi Seisaku no Kihon Hoko ni Ttsuite (Housing and Land Committee Report: On the Basic Framework of Housing and Land Policies towards the 21st Century), Tokyo: Housing and Land Committee.

Housing and Land Committee (2000) Jutaku Takuchi Shingikai Toshin: 11 Seiki no Yutakana Seikatsu wo Sasaeru Jutaku Takudhi Seisaku ni Tsuite (Housing and Land Committee Report: On Housing and Land Policies which Support a Good Life in the 21 st Century), Tokyo: Housing and Land Committee. 
Housing Bureau of the Ministry of Land, Infrastructure and Transport (2004) Jutaku Seisaku Kaikaku Yoko (Outline of Housing Policy Reform), Tokyo: Ministry of Land, Infrastructure and Transport.

Igarashi, Y. and Ogawa, A. (2003) Toshi Saisei wo Tou (Denouncing 'Urban Renaissance'), Tokyo: Iwanami Shoten.

Imada, T. (1989) Shakai Kaiso to Seiji (Social Class and Politics), Tokyo: Tokyo University Press.

Institute of Labour Administration (2004) Fukuri Kosei Jijo (The State of Employee Benefits), Tokyo: Institute of Labour Administration.

Japan Institute of Life Insurance (2003) Kigyo no Fukuri Kosei ni Kansuru Chosa (Research on Employee Benefits), Tokyo: Japan Institute of Life Insurance.

Kadono, Y. (2000) Kogai no 20 Seiki (Suburb in the 20th Century), Kyoto: Gakugei Shuppan Sha.

Kishimoto, S. (1978) Churyu no Genso (Phenomenon of the Middle Class), Tokyo: Kodan Sha.

Machimura, T. (1992) The urban restructuring process in Tokyo in the 1980s: transforming Tokyo into a world city, International Journal of Urban and Regional Research, 16(1): 114-28.

Matsumoto, M. (1998) Seijin mikonsha no Tokyo kennai niokeru kyoju jittai (Housing conditions of unmarried people in the Tokyo metropolitan area), Sogo Toshi Kenkyu (Comprehensive Urban Studies), 66: 79-92.

Matsumoto, K. (2002) Toshi mondaika suru manshon no iji kanri (Urban question and condominium management), in Japan Architectural Institute (ed.) Gendai no Kyojuchi Saihen to Jukankyo Seisaku (Restructuring of Residential Districts and Housing Policy), Tokyo: Japan Architectural Institute, pp. 91-9.

Ministry of Land, Infrastructure and Transport (2003) Tochi Hakusho (Government White Paper on Land), Tokyo: National Printing Bureau.

Ministry of Land, Infrastructure and Transport (2004) Tochi Hakusho (Government White Paper on Land), Tokyo: National Printing Bureau.

Ministry of Land, Infrastructure and Transport (2005) Tochi Hakusho (Government White Paper on Land), Tokyo: National Printing Bureau.

Miyake, J. (1979) Jutaku kensetsu keikaku no mondai to kadai (Issues on housing construction plan), in E. Shimoyama, H. Mizumoto, K. Hayakawa and Y. Wada (eds) Jutaku Seisaku no Teigen (Proposal towards Housing Policy), Tokyo: Domesu Shuppan, pp. 31-46.

Miyake, J. (1985) Jutaku shijo ron (On the housing market), in Shin Kenchikugaku Taikei Henshu Iinkai (Committee on New Architectural Theories) (ed.) Shin Kenchikugaku Taikei, vol. 14, Haujingu (New Theories of Architecture, vol. 14, Housing), Tokyo: Shokoku Sha, pp. 73-153.

Miyake, J. (1991) Jinko kozo no henka to jutaku jijo (Demographic Change and Housing Conditions), in K. Hayakawa (ed.) Jutaku Jinken no Shiso (Thinking on Rights to Housing), Tokyo: Gakuyo Shobo, pp. 133-54.

Murakami, Y. (1984) Shin Chukan Taishu no Jidai (The Era of the New Middle Mass), Tokyo: Chuo Koron Sha.

Ohmoto, K. (1985) Fukushi kokka to wagakuni jutaku seisaku no tenkai (The welfare state and housing policy in Japan), in Institute of Social Science, Tokyo University (ed.) Fukushi Kokka, vol. 6, Nihon no Shakai to Fukushi (The Welfare State, vol. 6, Japanese Society and Welfare), Tokyo: Tokyo University Press, pp. 397-455. 
Ohmoto, K. (1996) Kyoju seisaku no gendai shi (Modern history of housing policy), in K. Ohmoto and M. Kaino (eds), Gendai Kyoju: Rekishi to Shiso (Housing Policy: History and Ideology), Tokyo: Tokyo University Press, pp. 89-120.

Oizumi, E. (1994) Property finance in Japan: expansion and collapse of the bubble economy, Environment and Planning A, 26(2): 199-213.

Omi, T., Kitahara, K. and Sato, S. (1991) Shoyusha fuzai ga motarasu manshon no chiiki juyo tokusei (Local demand for housing and non-owner-occupied condominiums), Journal of Architecture and Planning, 595: 133-41.

Otake, F. (2005) Nihon no Fubyodo (Inequality in Japan), Tokyo: Nihon Keizai Shinbun Sha.

Postal Services Research Institute (2005) Kakei niokeru Kinyu Shisan Sentakuto ni Kansuru Chosa Kekka Hokokusho (Research Report on Family Finance and Financial Assets), Tokyo: Postal Services Research Institute.

Recruit (2005) Shutoken Shinchiku Manshon Keiyakusha Doko Chosa (Research on New Condominium Purchasers in the Capital Metropolitan Area), Tokyo: Recruit, Co.

Research Institute of Employee Benefits (2003) Fukuri Kosei Taishoku Kyufu ni Kansuru Sogo Chosa (Comprehensive Research on Employee Benefits), Tokyo: Research Institute of Employee Benefits.

Ronald, R. (2004) Home ownership, ideology and diversity: re-evaluating concepts of housing ideology in the case of Japan, Housing, Theory and Society, 21(2): 49-64.

Saito, A. and Thornley, A. (2003) Shifts in Tokyo's world city status and the urban planning response, Urban Studies, 40(4): 665-85.

Sato, T. (2000) Fubyodo Shakai Nihon (Inequality in Japanese Society), Tokyo: Chuo Koron Shinsha.

Sectional Committee on Housing and Land of the Panel on Infrastructure Development (2003) Aratana Jutaku Seisaku no Arikata ni Tsuite (On New Housing Policy), Tokyo: Sectional Committee on Housing and Land of the Panel on Infrastructure Development.

Sectional Committee on Housing and Land of the Panel on Infrastructure Development (2004) Aratana Jutaku Seisaku ni Taiou Shita Seidoteki Wakugumi no Arikata ni Kansuru Chukan Torimatome (Tentative Report on the Institutional Framework of New Housing Policy), Tokyo: Sectional Committee on Housing and Land of the Panel on Infrastructure Development.

Shirahase, S. (2005) Shoshi Korei Shakai no Mienai Kakusa (Invisible Inequality in the Ageing and Low-Fertility Society), Tokyo: Tokyo University Press.

Sonoda, M. (2000) Shutoken ni okeru kosodate setai no jutaku sozoku no kanosei to soreni kanrensuru jutaku juyo no tokusei (The effect of the intergenerational transfer of the house on the housing need for young family household), Meiji Daigaku Riko Gakubu Kenkyu Hokoku (Research Report, School of Science and Technology, Meiji University), 23: 23-30.

Sumita, S. (1980) Mochiya seisaku no shinshiten (New perspectives on home ownership policy), Kokumin Seikatsu Kenkyu (Research on Social Economic Life), 19(4): 51-8.

Tachibanaki, T. (1998) Nihon no Keizai Kakusa (Economic Inequality in Japan), Tokyo: Iwanami Shoten.

Tachibanaki, T. (ed.) (2004) Risuku Shakai wo Ikiru (Living in a Risk Society), Tokyo: Iwanami Shoten.

Tamaki, S. (1974) Mochiya shiko to shakuya shiko (Directivity towards owner-occupied housing and rental housing), in Nishiyama Kenkyushitsu (Nishiyama Research Unit) 
(ed.) Gendai no Seikatsu Kukan (Modern Living Space), Tokyo: Keiso Shobo, pp. 283-307.

Yui, Y. (2004) Daitoshi niokeru shinguru josei no manshon konyu to sono haikei (Condominium purchase by single women in large cities) in Y. Yui, H. Kamiya, Y. Wakabayashi and T. Nakazawa (eds) Hataraku Josei no Toshi Kukan (Urban Space and Working Women), Tokyo: Kokin Shoten, pp. 141-68. 


\title{
3 Transformations in housing construction and finance
}

\author{
Eiji Oizumi
}

\section{Introduction}

Construction is a major engine in the development of the housing market, and Japan's housing market in particular has been characterized by substantial continuous and sustained housing construction. In Western European countries, housing construction peaked in the late 1960s and early 1970s, and subsequently began to decline (Ball and Harloe, 1998). In contrast, Japan maintained a high level of housing construction, averaging more than 1.4 million units a year from the mid-1970s, despite the influence of cyclical fluctuations in production conditions. International comparison of construction volume by population reveals considerable differences in the Japanese case. The number of houses newly constructed per thousand people ranged between three and six units during the 1980s and 1990s in Britain, Germany, France and the USA. Japan, in contrast, maintained a level of between ten and fourteen units, even though this fell to nine units in the late 1990s (JSS, 2004).

However, housing construction in Japan decreased significantly during 1997 and 1998, and has remained at a level of less than 1.2 million units per year. This longlasting depression in the housing market can be explained by the following macroeconomic factors: first, falling land prices and bad debt problems, and secondly, economic depression and increasing unemployment rates under conditions of increasingly globalized competition. Retrospectively, the Japanese economy and urban development in the 1980s were quite spectacular and featured massive exporting power in terms of products and capital, centralization of international money-flows around Tokyo's market and the promulgation of the myth that land prices went up in perpetuity. However, in the 1990s the Japanese miracle turned sour. Although most economists tend to argue that the deflationary crisis in the Japanese economy ended in 2003, the outlook for housing construction is still gloomy. Indeed, the housing construction system has been faced not only with a temporary down-phase in the economic cycle but also with the inauguration of a new phase of structural change which will strongly affect the housing market. 


\section{Eiji Oizumi}

Japan's housing market growth has been led by mass housing construction and fuelled by expanding provision of housing loans that promoted the rapid growth of mass home ownership. However, the housing market has faced a critical turning point since the 1990s. This is the context underlying the restructuring of government housing policy. A central purpose of this chapter is to attempt to expose the dynamics of transitions in the housing market and housing policy, focusing on, first, the changes in the housing loan market under conditions of financial deregulation and privatization; secondly, competition and concentration among house-builders under changing market conditions; and thirdly, the government's new policy approach to recovery in the housing market. It is important to note the conduct of major industrial associations concerned, as the roles they play as pressure groups strongly affect government policy-making processes. This chapter thus offers a comprehensive analysis of transformations in housing construction and finance, and their real world implications.

\section{The social and economic context of transformation}

There are a number of other factors that influence the housing market and construction sector in Japan which provide a framework for understanding the dynamics of transformations in housing finance, construction and provision. First, there is evidence that economic and social polarization is growing. Job security has been substantially eroded for many classes of working people. The drastic changes in the labour market are resulting in an increasing polarization of incomes and living conditions and greater uncertainty and insecurity. These changes are not just impacting lower income groups but also the middle classes as well. Secondly, Japan faces the serious problem of a shrinking population and the prospect of an ageing society. These demographic and social changes are the direct result of lower birth-rates. Japan has presently one of the lowest birth-rates in the world (the total fertility rate in Japan was as low as 1.29 in 2004). This low rate is, in the long term, conducive to a significant decrease in the size of population and increase in the proportion of older people. While the population of Japan in 2000 was approximately 127 million, it is expected to decline to less than 118 million by 2030, representing a decrease of 7.4 per cent over just three decades. Over the same period, the proportion of people aged 65 years and more is expected to increase from 17 per cent to 30 per cent (CSI, 2003). This trend will certainly create a long-term decrease in housing demand.

Thirdly, the above changes are uneven across regional economies and local housing markets. While the property market in central Tokyo is showing signs of full recovery, most other big cities and regional centres remain in a state of economic depression. The polarization of housing markets is thus effectively ongoing. Consequently, it is evident that housing construction is in a state of distress as the market faces the unfavourable prospect of continuous decline in 
terms of effective demand for houses. Increased uncertainty and risk are preeminent in perceptions of the housing market.

The long-lasting depression has also affected the housing finance market. Despite extraordinarily lower interest rates, the balance of housing loans is at a standstill with an aggregate of over $¥ 183$ trillion ( $£ 915$ billion; $¥ 200=£ 1$ ) from 2000. The privatization of housing finance, which has been an important part of the restructuring of the post-war housing system, has provided banks with a growing lending market. Although an increase in the provision of housing loans from banks has been observed, it has only replaced decreased provision of housing loans from the public sector.

\section{The marketization of housing provision}

In this critical context, the drastic restructuring of housing policy has been ongoing. In post-war Japan, public policy promoting housing provision was served mainly by the three institutions established in the 1950s: the Government Housing Loan Corporation (GHLC) financing middle-class private home purchase, the Public Housing System providing the lower income groups with rented houses, and the Japan Housing Corporation providing residents of large cities with houses for rent and sale (the latter was afterward merged into the Housing and Urban Development Corporation, HUDC). These institutions have played important roles in the mass housing system whereby acute housing shortage caused by rapid urbanization was to be solved (see Hirayama, in this volume). However, since the latter half of 1990s the government has engaged in drastic restructuring of these institutions, and has been seeking to further marketize the housing provision system.

With the revision of the Public Housing Law in 1996, the upper income limit for tenants of public housing was lowered, while the government simultaneously curtailed its subsidies for public housing construction. These measures led to increasing residualization in the provision of public housing. In 1999, HUDC was abolished and replaced with the Urban Development Corporation (UDC), which began to withdraw from housing provision. Subsequently, the UDC was abolished in 2004 and replaced with the Urban Renaissance Agency in order to provide further support for private urban redevelopment businesses. The government is also seeking to abolish the GHLC by 2007 and replace it with a new corporation, the Housing Finance Agency, dealing exclusively in securitization of bank housing loans. Overall, this ongoing restructuring is in accordance with the principle that housing policy has to be limited to supplement the operation of the market (Honma, 2004). This essentially follows a neo-liberalist doctrine that supports both privatization and deregulation in Japan's housing system.

Viewed in a historical light, the transitions in Japan's housing policy can be characterized by three stages. First, the interventionist state in early post-war Japan was strongly growth-oriented, and established housing policies subordinate 


\section{Eiji Oizumi}

to this aim. In the next stage, this developmentalist strategy was strengthened by the introduction of privatization and deregulation policies during the 1980s when the form of neo-liberalism represented by Thatcherism and Reaganism expanded its influence more internationally. In this context, housing policy encouraged home ownership and strongly promoted the growth of the housing market. In the present stage, starting from the 1990s, privatization and deregulation have been escalated across all industries and all regions. This neo-liberalist approach aims to prop up markets troubled by the macro-economic conditions and increasingly globalized competition. The restructuring of housing policy has been carried out following the neo-liberal principles of the new strategy in Japanese economic governance.

\section{Housing finance under deregulation and privatization}

Whereas the GHLC had been exclusively providing the middle classes with housing loans during the 1950s and 1960s, it was not until the 1970s that the housing loan market started to demonstrate more comprehensive growth. Annual GHLC loans increased in value from just over $¥ 1$ trillion ( $£ 5$ billion) in 1973 to $¥ 3$ trillion ( $£ 15$ billion) by 1979 , and to a total $¥ 5.8$ trillion ( $£ 29$ billion) by 1989. This considerable increase was critically supported by the government's business-cycle policy. When an economic recession occurred during 1970 and 1971, the government increased the public funds to be distributed by the GHLC in order to stimulate the economy. Since then, the government has utilized GHLC loans following principles of Keynesian fiscal policy. From the government's perspective, the expansion of GHLC loan provision was an effective and relatively inexpensive policy tool, because it immediately led to the expansion of housing construction with strong ripple effects into related industries (see Honma, 1987; GHLC, 2000).

\section{The growth of bank housing loans}

Nevertheless it was notable that, despite the rapid growth in GHLC loans, housing loans by private banking institutions grew faster than those of the GHLC from the 1970s. Housing finance became an important, relatively safe and profitable business for banks as high economic growth ended and corporate finance began to shift away from intermediated finance to equity finance. Bank housing loans reached $¥ 5.5$ trillion ( $£ 27.5$ billion) in 1980 and increased to a peak, in 1989 , of over $¥ 21$ trillion (£105 billion).

The growth of the housing loan market reached a problematic climax in the period of the bubble economy from 1985 to 1990 (Oizumi, 1994; Itoh, 2002). After the collapse of the bubble, there was a turning point. Figure 3.1 illustrates how the housing loan market has adapted a new pattern since the 1990s. In the 


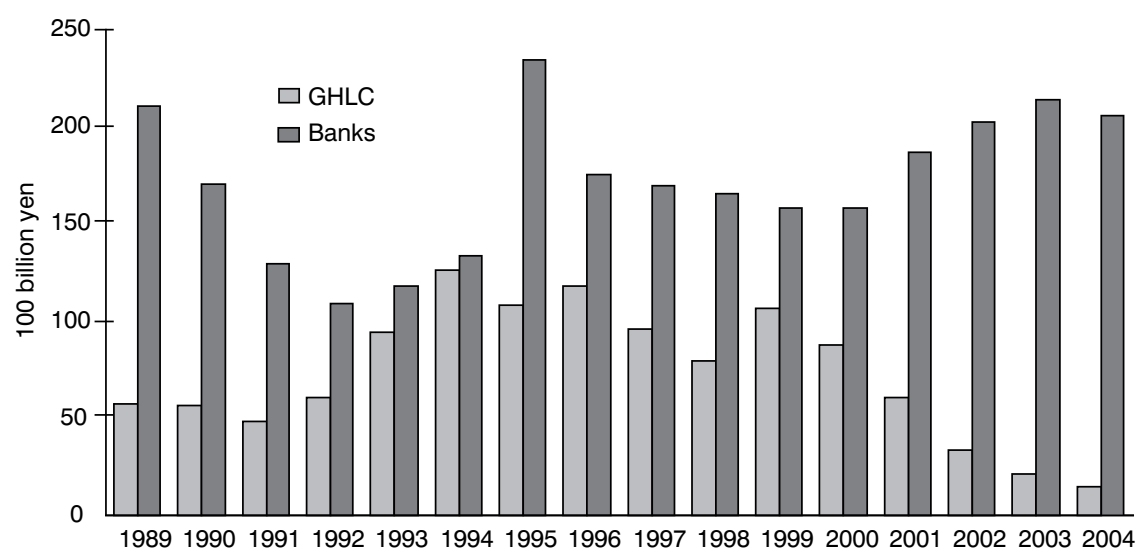

3.1 Newly advanced housing loans 1989-2004

Source: Government Housing Loan Corporation.

Note: Banks include other private financial institutions.

early 1990s bank housing loans decreased substantially because the bubble had burst, while GHLC kept lending as a means to counter market recession. Bank loans expanded again in 1995, and subsequently maintained a high level, while the level of GHLC loans began to decrease. These contrasting trends have become more obvious and advanced since 2001.

The reasons for these changes can be explained by both financial deregulation and the extraordinary easing of monetary policy, which were introduced in the latter half of 1990s. Japan's 'financial Big-Bang' policy, announced in 1996, set out rapid, comprehensive deregulatory reforms for Japan's financial system (between 1999 and 2001), generated a drastic wave of mergers among large commercial banks and had a severe impact on regional banking institutions which began to disappear (JSRI, 2000; Oizumi, 2005). These trends were exacerbated by the increasing pressure of bad debt problems. To mitigate the hardship in banking, the Bank of Japan gradually reduced its basic interest-rate from 0.5 per cent in September 1995 to 0.1 per cent in September 2001, and, through open market operations, supplied a vast amount of money in order to augment the reserve-funds private banks hold. This extraordinary monetary policy has caused a rapid decline in short-term and long-term market interest-rates (significantly, the interest-rate on call money has fallen to 0 per cent).

The wave of banking mergers created four mega-banking groups covering both lending and securities businesses. These are Mitsubishi-Tokyo, Mizuho, Sumitomo-Mitsui and UFJ (the UFJ banking corporation is due to be merged with Mitsubishi-Tokyo in 2006). Despite the overwhelming concentration of funds in these mega-banks, there are some serious weaknesses in the mega-banking sector. These include underdeveloped skills in financial asset management and 


\section{Eiji Oizumi}

reduced profitability caused by the vast backlog of bad loans. The mega-banks are, therefore, faced with the double necessity of making forays into securities markets, and developing profitable money-lending markets. Thus, the mega-banks are eagerly launching into consumer finance business and expanding further into the housing loan sector. At the same time, regional banking institutions, which have specialized as financial intermediates for medium-sized and small firms, also expanded into housing loans in order to compensate for increased risk in lending to firms. Hence, under the strong competitive pressure caused by financial deregulation, housing finance markets have become an arena where major banks as well as local banks compete to expand their lending.

Under these market conditions the GHLC has been an impediment to banks expanding their housing loans services. Indeed, supported by the government policy aimed at stimulating the economy, GHLC loans continued to expand. The Japanese Bankers Association (JBA), the largest advocacy organization of banking business circles, has strongly asserted that the GHLC has been crowding out the private bank housing loan sector and has in fact restricted expansion.

\section{The GHLC facing risks and extinction}

GHLC lending in the post-bubble era has encountered serious problems. Increased credit risk has been caused by over-lending without regard for borrowers' weakened ability to pay in the conditions of the deeply depressed economy. To offer easier access to borrowing the GHLC escalated special measures that kept repayments artificially low for the first five years. Such measures had been introduced since the 1980s. This repayment system presupposed that borrower's incomes would continue to increase steadily, with the rate of repayment therefore adjusted to surge from the sixth year. Consequently, many users of this repayment system have been unfortunate and have fallen into a double bind of abrupt upturn in their outgoings and a negative equity problem due to the depression both in the economy and the housing market. The result has been a remarkable increase in repayment arrears and bankruptcies. In 2003, arrears and bankruptcies in the repayment of GHLC loans amounted to $¥ 811$ billion (£4.1 billion), and in only eleven months, from April 2002 to February 2003, 22,000 households lost their homes due to repossession (Shimamoto, 2005).

In addition, relaxed monetary policy and lower interest-rates caused further problems for the GHLC. Money markets had provided an extraordinarily easy system of finance since the late 1990s. Under such conditions banks had increased lending for housing loans. As a result, the interest-rates on housing loans declined drastically. Since GHLC loans were fixed at a higher rate, GHLC borrowers rushed to convert their debts to banks. The GHLC suffered quite a loss from increased prepayment risks. Although new lending continued to expand, an increasing proportion of public funds distributed to the GHLC remained unused. 
While borrowers continued to make prepayments to the GHLC, the GHLC could not carry these prepayments back to the government. Prepayment by borrowers amounted to $¥ 9.9$ trillion (£49.5 billion) in 1995 and then averaged $¥ 6.3$ trillion (£31.5 billion) between 1996 and 2001. The GHLC suffered substantial losses and hence government subsidy was swelled, averaging $¥ 518$ billion ( $£ 2.6$ billion) between 1996 and 2001. This situation reinforced claims that the operation of the GHLC was highly inefficient.

In short, both the over-lending to counter the market depression and easy monetary policy, to rescue banks in hardship resulted in increases in costs and risks at the GHLC. From the neo-liberalist perspective of government and banking circles this situation offered a justification for the abolishment of the GHLC. In December 2001 the government adopted a programme to privatize public corporations, including the abolition of GHLC. The programme set out how to replace the GHLC with a new corporation, dealing exclusively in securitization of bank housing loans, within five years. Accordingly, the GHLC began to gradually curtail its loan services from 2002, while the government, in principle, reduced the provision of subsidy. In February 2003 the JBA published a statement that approved the government's programme and asserted the need for the GHLC to speed up its withdrawal from primary lending as well as the necessity to replace the corporation (forcing it to withdraw altogether from lending).

The government and JBA anticipated that the abolition of the GHLC would widen the market wherein corporate bank housing loans could expand further and the disposal of GHLC loans through securitization would offer private financial institutions opportunities to obtain low-risk, high-profit financial assets. The new corporation dealing with the securitization business and a growing secondary market of housing loans was conceived to follow the institutional model set out in the USA of the Federal National Mortgage Association (Fannie Mae) and the Federal Home Loan Mortgage Corporation (Freddie Mac).

These circumstances have fundamentally shaped changes in the housing loan market. The GHLC, preceding the inauguration of a new corporation, has begun the securitization of housing loans, while phasing out lending. The growth in bank housing loans from 1995 has been partly facilitated by the shift of borrowing away from the GHLC, and partly through the sale of new types of loans to be securitized by GHLC. The four mega-banks have attempted to take full advantage of this opportunity. Their share of the housing loan market amounted to $¥ 28$ trillion ( $£ 140$ billion) in 2003, representing 23 per cent of total aggregate bank housing loans. This increased to $¥ 32$ trillion ( $£ 160$ billion) over the following two years.

\section{Potential consequences in housing finance}

Despite problems generated by the prioritization of economic policy, the GHLC has played an important role in developing housing provision. The GHLC provided 


\section{Eiji Oizumi}

many working-class people with easier access to home ownership through the facilitation of long-term lending conditions with low, fixed interest-rates. At the same time it contributed substantially to the improvement of dwelling quality, through the special building standards applied to its lending. In abolishing the GHLC, the government is undermining many necessary and effective elements in housing policy. Essentially, it will generate many new problems in the housing finance market.

It seems questionable whether banks will provide an adequate substitute for the GHLC in providing stably employed people with easy access to home ownership. A recent GHLC report indicated that 90 per cent of bank housing loans consist of lending with both an adjustable interest-rate and a fixed interest-rate applicable for only five years or less, whereas the GHLC has provided long-term, fixedinterest lending for between 25 and 35 years. While GHLC long-term and fixed interest-rates have been supported by public funds, bank lending is funded through deposits and bonds with changing market interest-rates. Consequently banks find it impossible to supply long-term housing loans with fixed interest-rates because it is difficult for them to manage the risks that changing interest-rates incur.

Although the securitizing of bank loans would make it possible for banks to sell long-term housing loans with fixed interest-rates, there are various other risks including credit risk, prepayment risk and liquidity risk on mortgage-backed securities. Under financial deregulation, bank lending policies are increasingly volatile. The housing finance market is likely to suffer more and more from the fickle and changing conditions of financial markets. Securitization of housing loans cannot cover such financial risks completely and the development of a secondary market may cause some serious troubles for local housing loan markets, as the USA experience demonstrates.

The examination by Dymski and Isenberg (1997) of US housing finance market deregulation revealed the following problems. First, the integration of housing finance into the main financial market, through the development of a secondary mortgage market, destabilized the housing finance market. In particular, an increase in interest-rates frequently created a lock-in effect against housing loans. Secondly, because of deregulation, money-flows in housing mortgages increased volatility. Thirdly, the standardization of housing mortgages, which is requisite for issuing mortgage-backed securities, furthered 'redlining' (discrimination in mortgage lending). Fourthly, adjustable mortgage interest-rates, which were introduced, made the risks of changing interest-rates transferable to borrowers. Lastly, in stagnant local areas, where the spill-over effects of increasing property values could not be anticipated, the entire local lending market declined. Overall, Dymski and Isenberg (1997) noted that US housing finance did not become less pro-cyclical because of the widespread adoption of securitization in the 1980s, and also that the wider channel for 'standard' loans on 'standard' houses threatened to reduce the availability of 
financing for 'non-standard' housing loans, restricting the type of neighbourhood and the income/wealth criteria of borrowers.

In the case of Japan GHLC reports indicate that GHLC borrowers are concentrated in the lower middle and middle income classes with annual incomes ranging between $¥ 4$ and $¥ 6$ million ( $£ 20,000$ and $£ 30,000$ ) while those who borrow from banks alone are concentrated in the upper middle and upper income classes with incomes of over $¥ 8$ to $¥ 13$ million ( $£ 40,000$ to $£ 65,000$ ). While the abolition of the GHLC and the withdrawal of government lending will enable banks to expand lending to the lower middle and middle income classes, banks will face the increasing necessity of managing credit risk. Bank lending policy is normally discriminatory against 'risky' classes, including the self-employed, part-time employees and females living alone. In fact, the GHLC has asserted that its continued existence is necessitated by the need to support housing finance for lower income groups which the private banking sector is incapable of dealing with. The financing of lower income and 'risky' groups by banks and private lenders will be an increasingly serious concern due to the ongoing polarization of the economy.

So far, as the recovery of the economy has been sluggish, extraordinarily low interest-rates have continued. This condition is, nevertheless, unsustainable. Once monetary policies are tightened, bank housing loans will be more selectively or discriminatively distributed and interest-rates will increase. This will, arguably, lead to a greater propensity for risks to be transferred to borrowers where banks introduce preferable adjustable interest-rates on housing loans. Furthermore, most households are vulnerable to such acute risk. The changes in the housing loan market, therefore, will increasingly lead to greater problems of housing affordability. With the securitization of bank housing loans, some risks will inevitably be borne by the government as the securitization programme is supported by GHLC guarantees (and consequently its successor's guarantee) against debts, repayment failures and mortgage-backed securities. Therefore increasing costs generated by market risk will largely necessitate growing government subsidy for guarantor institutions.

It is also questionable whether banks will accept outright public regulation on the building standards applied to their lending. GHLC loans have required special building standards stricter than regulations in the standard Building Code. For instance, there are regulations on the structure and size of detached houses, and common facilities provided in apartment buildings, when obtaining a GHLC loan, while no such regulations exist in the Building Code (Honma, 1987). Alternatively, bank lending has been frequently extended to houses clearly breaking the Building Code. Despite the need to expand this kind of regulation to housing development, any role for housing finance in improving the quality of dwellings and their environments will remain limited, especially in context of ongoing financial deregulation. 


\section{Eiji Oizumi}

There is substantial evidence to support apprehension. When the GHLC started securitization activities in 2003, the Ministry of Land, Infrastructure and Transport (MLIT), which supervises the GHLC, stated that bank housing loans were to be securitized on condition that lending was made available to fund housing fulfilling the special building standards of the GHLC. Nevertheless, in the following year, this condition was relaxed by the MLIT to facilitate the diffusion of new types of loans among banks. It is evident that the government's housing finance policy is not oriented towards public interests but to the interests of banking circles.

Transformations in the housing finance system will result in an increase in market volatility and risk, financial discrimination against, and exclusion of, lower income and 'risky' categories of household. As long as the housing market and housing construction keep growing, banks will be able to expand their housing loans. However, the changing conditions of the housing market make predictions unreliable and banks may have to deal with unexpected economic conditions.

\section{House-builders in changing market conditions}

We now consider the potential volatility generated by changes in the structure of the housing system and economy in terms of house-builders and the housing market. Japan's growing housing market has been led by successive large-scale housing construction. Figure 3.2 illustrates this trajectory. Although housing shortages were satisfied by the early 1970s, when housing stocks exceeded the number of households in each part of the country, housing construction maintained average levels as high as, or more than, 1.4 million units a year. High levels of construction were sustained until a significant decrease occurred in the late 1990s.

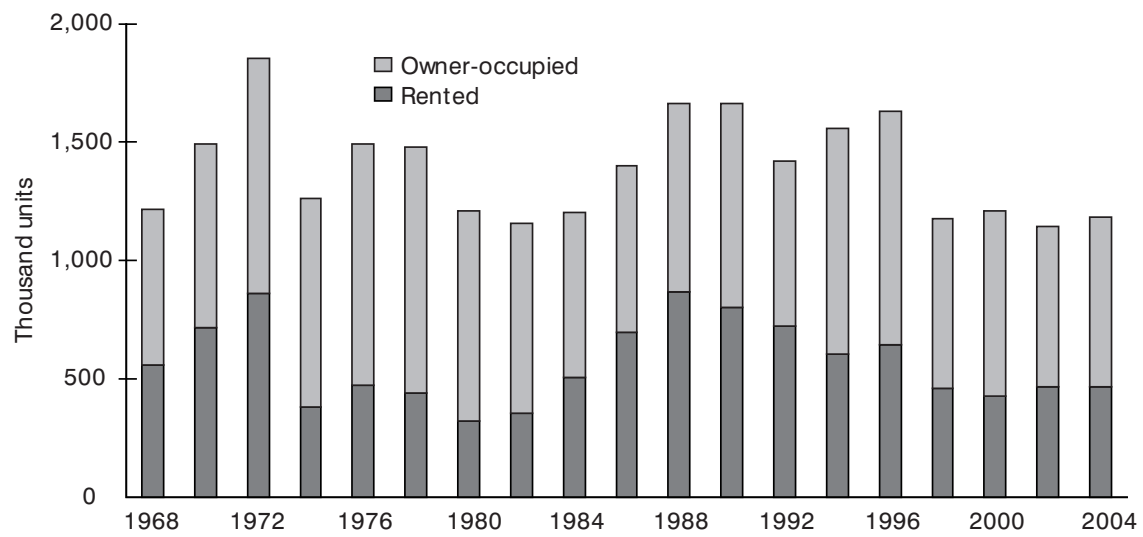

3.2 Housing construction starts 1968-2004 Source: MLIT Construction Statistics. Note: Owner-occupied housing includes houses built-for-sale. Rented housing includes those built by the public sector and company-owned houses and dormitories. 


\section{Housing construction and the 'Scrap and Build' spiral}

The results reported in Table 3.1 help to explain the pattern of successive housing construction over the years. Although increases in the stock of existing houses, from the mid-1970s to the 1990s, were lower than from the 1960s to the early 1970s, housing construction has remained at a high level. It is possible to estimate the number of demolished houses by subtracting the increase in existing houses from the number of newly constructed houses. The ratio of demolished houses to newly constructed houses, representing the 'scrap and build' ratio, was above 40 per cent in the 1960s and early 1970s, but it exceeded 50 per cent from the mid1970s. In contrast, the ratio in Britain over the same period did not exceed 5 per cent (Yamada, 2000).

The growth of the housing market is, therefore, characterized by active housing construction sustained mainly by the demolition of existing houses, leading to a 'scrap and build' spiral (for a consideration on the demand-side factors pertaining to the 'scrap and build' of housing, see Oizumi and Oi, 2005). We now consider the important aspects of housing construction in both owner-occupied housing market and the rented market sectors.

Under accelerating urbanization, from the mid-1970s, expanding demand for home ownership was satisfied by constructing both detached houses in suburbs and high-rise apartment houses in built-up areas. On the fringe and in built-up areas of big cities detached housing construction frequently took the form of 'minihousing developments'. These developments were made up of small detached houses on plots of less than 100 square metres, due to the pressure of rising land prices. The construction of rented housing, alternatively, decreased remarkably in

Table 3.1 Housing construction and 'scrap and build' ratio

\begin{tabular}{lllll}
\hline $\begin{array}{l}\text { Sample } \\
\text { period }\end{array}$ & $\begin{array}{l}\text { Increase in } \\
\text { stock }\end{array}$ & $\begin{array}{l}\text { Newly built } \\
\text { units }\end{array}$ & $\begin{array}{l}\text { Demolished } \\
\text { units }\end{array}$ & S\&B ratio \\
\cline { 2 - 5 } & $\begin{array}{l}\text { A } \\
\text { (thousand } \\
\text { units) }\end{array}$ & $\begin{array}{l}\mathrm{B} \\
\text { (thousand } \\
\text { units) }\end{array}$ & $\begin{array}{l}\text { C=B-A } \\
\text { (thousand } \\
\text { units) }\end{array}$ & $\begin{array}{l}\text { C/B*100 } \\
(\%)\end{array}$ \\
\hline $1963-68$ & 4,501 & 7,764 & 3,263 & 42 \\
$1968-73$ & 5,468 & 9,940 & 4,472 & 45 \\
$1973-78$ & 4,392 & 7,770 & 3,378 & 44 \\
$1978-83$ & 3,156 & 6,435 & 3,279 & 51 \\
$1983-88$ & 3,401 & 7,433 & 4,032 & 54 \\
$1988-93$ & 3,872 & 7,666 & 3,794 & 50 \\
$1993-98$ & 4,367 & 7,360 & 2,993 & 41 \\
$1998-2003$ & 3,620 & 5,927 & 2,307 & 39 \\
\hline
\end{tabular}

Source: MLIT Construction Statistics. 


\section{Eiji Oizumi}

the latter half of 1970s, as shown in Figure 3.2. Rental housing construction began to increase again in the first half of 1980s and, during the period of the bubble economy, constituted over 60 per cent of the housing construction in Japan's three major metropolitan areas. However, development was based on the speculative construction of small studio flats with floor space of less than 20 square metres. This kind of rented housing satisfied the expanding demand by unmarried young people in large cities.

The 'scrap and build' spiral caused a thorough transformation of the urban landscape. A sprawl of housing development emerged in suburbs, while highrise apartments, 'pencil buildings' and 'mini-housing developments' were wedged into built-up areas by developers. At the same time, in big cities, many densely crowded districts with old wooden housing remained. Although successive housing construction has improved the quality of owner-occupied housing stock, averaging 125 square metres in floor space per unit in 2003, their improvement has advanced unevenly between metropolitan and regional cities. Regression is marked in much privately rented housing stock, which averaged 48 square metres of floor space per unit in 2003, because rental housing construction has focused largely on small-size apartments while older stock has deteriorated (for a consideration of disparities in housing stock, see Sumita, 2003). Housing construction in Japan thus has a very peculiar character which can only be understood in context of the house-building industry led by 'scrap and build' activities.

\section{Growth of major house-building companies}

Broadly defined as the business element of housing provision, the house-building industry is characterized by the three functional aspects of housing development: residential land development, housing production and house marketing and sales (Ball, 2003). With reference to this functional definition, the main players in Japanese house-building industry can be identified as follows: 1) house-builders constructing mostly detached houses and low-rise flats, 2) general contractors constructing multi-storey buildings, 3) developers projecting real-estate development and dealing in the sales and management of real estate and 4) realestate agents dealing in the circulation of real estate. My concern here is mainly with house-builders and general contractors.

The Japanese house-builder system is composed of a dual-pyramidal structure. On the top layer, there are eight major companies sharing nationwide markets. On the bottom layer, there are a large number of small house-builders running several small-scale projects in local markets. The number of small house-builders in the country amounted to 180,000 at their peak in the latter half of 1970s, when they shared over 60 per cent of the housing construction sector. Since then, however, their number and share have been decreasing. A survey by the MLIT in 2001 indicated that, among the 136,000-strong group of small house-building firms, 92 
per cent use the conventional wooden framework method of construction, and 50 per cent construct annually less than four units. Their business is supplemented by repairing an annual average of less than ten units of existing houses (KSK, 2003).

The major companies are large prefabricating house-builders: Sekisui House, Daiwa House Industry, Misawa Homes, Pana Home, Sekisui Chemical (Housing division), Asahi Kasei Homes and Mitsui Home. Sumitomo Forestry (Housing division) is rather exceptional in its use of more conventional methods of construction. As shown in Table 3.2, the business of the major companies is remarkably high. Annual sales of Sekisui House and Daiwa House amount to 57,000 and 40,000 units respectively, while the other four companies each sell around 10,000 units or more. Through subcontracting relationships, these companies also keep a large number of small house-builders at their disposal. Hence, the influence of these major companies on the housing construction and market conditions, particularly in large cities, is very significant.

However, despite the dominance of large house-builders, the market share of small house-builders has not significantly diminished. The market conditions have allowed for the coexistence of large and small house-builders. This coexistence can be partly explained by the low substitutability of land and property, and low economies of scale in house-building. But it is, above all, the sustainable growth of the housing market though active housing construction that has provided the platform for this coexistence.

Starting from the latter half of the 1960s, an oligopoly of major companies established a market of prefabricated housing. At that time, during conditions of high economic growth and rapid urbanization, prefabricated housing production was promoted, not just as an innovative way of developing a 'modern housing industry', but as a new leading industry. The major prefabricating house-builders have been competing and leading the development of new house models. In pursuing differential advantages through marketing strategies, they have developed and introduced their products to consumers as upmarket commodities. They have erected their own nationwide logistics systems and sales networks, and established mass production and mass sales systems whereby houses can be provided to customers very rapidly.

Tempted by the success of large prefabricating house-builders, big business firms in other industries such as steel, car manufacturing and chemical industries, as well as large general contractors and real-estate agents, made forays into housebuilding. However, apart from a few successful cases such as Sumitomo Forestry, most newcomers failed to break through the entry barriers or claim significant market share. The remaining alternatives for expansion into the sector included the option of specializing in land development, multi-storey building construction and wood-frame construction methods imported from the USA. 


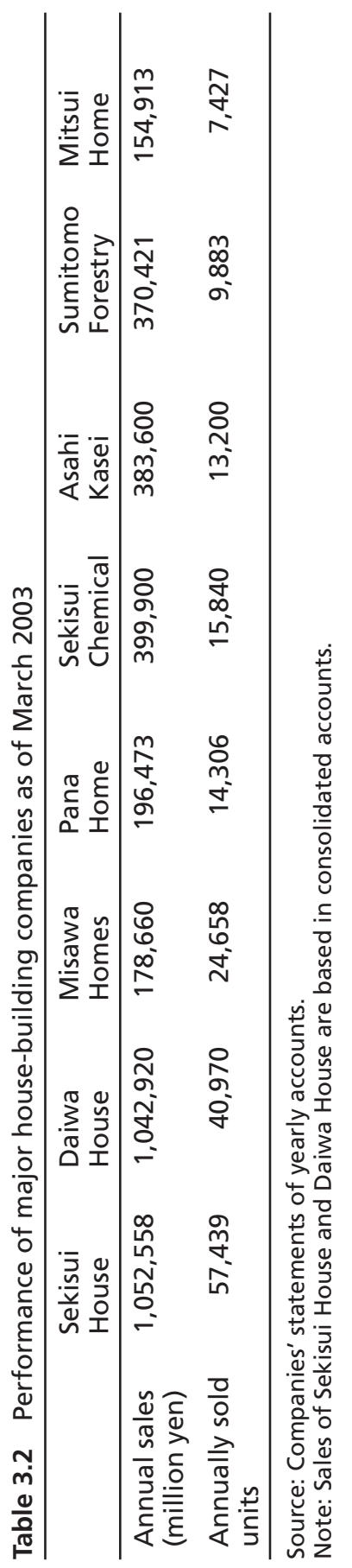


The growth of prefabricating large house-builders has exerted great influence upon housing construction as well as the housing market. In response to the technological innovations brought about by prefabrication methods, small housebuilders, using conventional methods, have also pursued the rationalization of the construction process by introducing pre-cut materials. The ceaseless development of new house models and their marketing by large house-builders constituted a major thrust which promoted and normalized the 'scrap and build' of housing.

It is since the latter half of 1970s that the construction of high-rise flats has advanced in competition with the construction of detached houses. The demand for home ownership, which significantly increased from the 1970s, was satisfied by providing both detached houses in suburbs and high-rise apartments in urban areas. High-rise apartments constitute a form of intensive land use that reflects the house-building industry's response to an increase in urban land prices. Indeed, the promotion of high-rise housing development was meant to offer some relief from household difficulties in purchasing houses, deriving from the inflationary pressures in the land market. The construction of high-rise housing contributed to the absorption of the large increase in demand for property ownership at affordable prices.

These conditions promoted the construction of high-rise flats by general contractors. The most successful case is Haseko Corporation, which has advanced its construction business though its property agency division. The strategy adopted by Haseko involves the development and planning of suitable sites in advance, and the subsequent promotion of construction projects to developers. Typically, general contractors only undertake construction work and hence the initiative in housing development is normally taken by developers or real-estate agents. But Haseko does not just contract to build high-rise apartments, as it also engages in sales and management jointly with developers. This joint-venture business approach peculiar to Haseko raised the company up into the top group of companies constructing high-rise apartments. Haseko has presently a market share of 14 to 15 per cent, while the share of most general contractors does not exceed 5 per cent each.

Whereas the post-war housing shortage was largely satisfied by the early 1970s, housing construction has kept growing, led by 'scrap and build' spiral. It is against this background of housing market conditions that the prosperity of most house-builders and general contractors should be measured. Moreover, the growth of the housing market has been fuelled by the increasing volume of housing loans facilitated by government and private financial institutions. At the height of the property boom in 1990, the total market price of the 1.6 million units of newly built dwellings amounted to $¥ 76.8$ trillion ( $£ 384$ billion), which represented about 18 per cent of GDP. This amount exceeded the total sales in the automobile market in the country. Thus, the housing market had an important role in the economy, 


\section{Eiji Oizumi}

despite the fact that its size also reflected the extraordinarily high level of land prices (Itoh, 2002).

\section{Competition and concentration among house-builders}

As shown by Figure 3.2, housing construction decreased significantly in 1998 and has remained at a low level. Housing provision is faced with a crisis posed by the increasing uncertainty in the housing market. Given the fact that most houses are provided through the market, the improvement of urban dwelling conditions is conditional on stable growth in the ability of households to pay rents or housepurchasing costs. The stability of households and household economies has, however, come under considerable strain in the post-bubble environment. The housing market faces unfavourable prospects due to the trend towards continuous decline in the effective demand for houses.

In order to understand the dynamics of the housing market, it is important to examine aspects of competition among house-builders and general contractors. Given the unfavourable market conditions, there has been a strong tendency for housing construction to be concentrated within big cities. The bulk of housing construction has taken place in the three main metropolitan areas: Tokyo (Greater Tokyo, Kanagawa, Saitama and Chiba prefectures), Nagoya (Aichi, Shizuoka, Gifu and Mie prefectures) and Osaka (Osaka, Kyoto, Hyogo, Nara, Shiga and Wakayama prefectures). These metropolitan areas account for 63.8 per cent of the total 1,193,000 housing units developed in 2004, while the Tokyo metropolitan area alone accounts for 37.7 per cent. In Greater Tokyo, where successions of population inflows have been observed since 1996, the inflow amounted to 66,000 people during the period from 2002 to 2003 . This compares to 24,000 people in Kanagawa and 11,000 in Chiba prefectures. By contrast, most of the remaining prefectures have experienced a series of population outflows.

Judging from the statistics reported in Table 3.3, the composition of housing construction demonstrates significant differences across the metropolitan and regional areas. A large share, 24.1 per cent (33.7 per cent in terms of floor space), of housing construction in the metropolitan areas is accounted for by high-rise apartments. Within rental housing construction, accounting for 34.1 per cent, a great majority is made up of high-rise apartments. The evidence also suggests that the construction of high-rise housing has been intensely concentrated in big cities. In particular, the share of Tokyo metropolitan area represents more than half of the total units of high-rise housing since 1998 and it further increased to 60 per cent in 2003. In this area, the construction of super high-rise housing with more than 20 storeys increased in 2000 to 2.4 times that of the preceding year.

The largest regional market in housing construction is that of the Tokyo metropolitan area, which has more recently been led by the construction of highrise apartments. In this, the major prefabricating house-builders seem to be at a 
Table 3.3 Differences in the composition of housing construction between the three metropolitan areas and the other local areas in 2004

\begin{tabular}{|c|c|c|c|c|c|}
\hline & \multirow{2}{*}{$\begin{array}{l}\text { Total } \\
\text { areas } \\
\text { (thousand } \\
\text { units) }\end{array}$} & \multicolumn{2}{|c|}{ Metropolitan areas } & \multicolumn{2}{|c|}{ Other local areas } \\
\hline & & $\begin{array}{l}\text { (\% in } \\
\text { units) }\end{array}$ & $\begin{array}{l}\text { (\% in } \\
\text { floor } \\
\text { space) }\end{array}$ & $\begin{array}{l}\text { (\% in } \\
\text { units) }\end{array}$ & $\begin{array}{l}\text { (\% in } \\
\text { floor } \\
\text { space) }\end{array}$ \\
\hline Owner-occupied & 367 & 24.4 & 20.5 & 41.9 & 60.6 \\
\hline Built-for-sale & 349 & 40.2 & 50.8 & 15.3 & 16.4 \\
\hline apartment & 207 & 24.1 & 33.7 & 9.8 & 9.9 \\
\hline detached & 139 & 15.9 & 17.1 & 5.3 & 6.3 \\
\hline Rented & 468 & 34.1 & 24.6 & 41.0 & 21.8 \\
\hline $\begin{array}{l}\text { Constructed } \\
\text { units } \\
\text { (thousand units) }\end{array}$ & 1,193 & \multicolumn{2}{|c|}{761} & \multicolumn{2}{|c|}{432} \\
\hline
\end{tabular}

Source: MLIT Construction Statistics.

Note: \% indicates composition of houses built in each area.

disadvantage compared to large general contractors and developers. In Greater Tokyo and Osaka prefecture, prefabricated housing is limited to 9 per cent and 7.2 per cent, respectively, of the housing construction in each area. The top three regions for prefabricated housing are Okayama (with 28.2 per cent prefabricated housing), Yamaguchi (27.6 per cent) and Fukui prefecture (24.0 per cent), which are located more rurally. The total volume of prefabricated housing construction decreased from a peak of 340,000 units in 1996 to 243,000 units in 2003. Under these pressing conditions of intense competition, the power gap is widening between the strongest two construction companies, Sekisui House and Daiwa House, and other competitors.

Facing reduced market opportunities, business diversification is an increasingly important strategy for major house-builders. Sekisui House now has 96 affiliated companies engaging in diverse businesses including real-estate transactions and management, land development, landscape gardening, finance and cable television. Daiwa House has more than 50 companies under its umbrella extending over realestate trading and management, home centres, tourism and hotels. Furthermore, in order to contain the impact of general contractors and developers, Daiwa House and, more belatedly, Sekisui House have advanced into the construction of highrise apartments. Evidence of diversification can be found not just with respect to major house-builders, but also among major developers and real-estate agents. However, the business diversification approach to hedging market risks can bring about additional risks of its own. The failure of Daikyo, a major developer, and Misawa Home provide clear examples. 


\section{Eiji Oizumi}

Large house-builders are increasingly competing in the expansion of production and sales of their products. Competitive efforts are being made to produce a variety of articles on the one hand, and to curtail their production costs on the other. However, although these joint efforts of differentiated production and costreduction are necessary, they may also conflict. Consequently, there appear to have been efforts made among large house-builders to push out or try to exclude small homebuilders from the market.

The practice of eliminating small house-builders is gaining momentum. The depression in the housing market has undermined the coexistence between large and small house-builders. Table 3.4 illustrates the impact of market trends on small house-builder firms and smaller carpenter firms. The number of small housebuilder firms decreased from 97,000 in 1981 to 92,000 in 1991, but it began to recover thereafter, reaching 98,000 by 1996 , and 95,000 by 2001 . The number of the employees in this sector increased from 431,000 in 1981 to 504,000 in 1991, but it fell significantly to 470,000 in 2001. Over the 1981-2001 period, the number of smaller carpenter firms, which peaked at 104,000 in 1972, decreased by 28,000, while the number of employees fell by 44,000. These statistics indicate that the trend toward collapse among small carpenter firms in the sector of smaller housebuilders is significant, but there is also evidence that the degree of concentration among small house-builders has advanced remarkably since the 1990s.

The economic depression and intensified competition in the housing markets are strengthening the process of elimination among small house-builders. Some researchers predict the extinction of as much as a third of small house-builders as well as the reduction of another third to the status of subcontractors of large house-builders in the near future (KSK, 2003). In fact, the construction work subcontracted from large house-builders to smaller house-builders located in large cities has become essential to the survival of the latter. Furthermore, the business of small house-builders has traditionally depended on repair work, but

Table 3.4 Elimination and concentration of small house-builders

\begin{tabular}{lccc}
\hline & 1981 & 1991 & 2001 \\
\hline $\begin{array}{l}\text { Number of small firms } \\
\text { Building-firms }\end{array}$ & 96,589 & 92,489 & 95,391 \\
$\begin{array}{l}\text { Carpenter-firms } \\
\text { Number of employees }\end{array}$ & 67,924 & 62,026 & 40,380 \\
Building-firms & 431,302 & 503,632 & 469,942 \\
Carpenter-firms & 164,612 & 177,624 & 120,579 \\
\hline
\end{tabular}

Source: Ministry of Internal Affairs and Communications, Establishment and Enterprise Census.

Note: 'Building-firms' indicates wooden house-building contractors. 
there is now stronger competition from large house-builders in this business as well. Indeed, the major house-builders have conceived business strategies centred on reorienting small house-builders toward subcontracting activities and adding local markets for housing construction and reform work to their own portfolios. However, it is also noticeable that some franchise-groups organized by local house-builders have been growing since the mid-1980s. This process may result in strengthening their marketing capabilities.

\section{New housing policy: one last 'scrap and build'?}

Given the difficulties posed by the stagnating housing market, major housebuilders acting as a pressure group exert substantial influence on government housing policy-making. This section offers an assessment of recent urban and housing policies in terms of their novel objectives and their implications for the house-building industry.

\section{Government 'urban renaissance' policy}

Japanese urban policy is presently determined by the government's 'urban renaissance' policy of 2001. The measures taken by the government to implement this policy may be viewed as merely an acceleration of the deregulation and privatization processes in urban redevelopment which started in the 1980s. The urban policy was associated at that time with the objectives of resolving the dual problem of international trade friction and low economic growth (Oizumi, 1994, 2002a), whereas they are now more concerned with the deflationary crisis and bad debt problems.

The 'urban renaissance' policy has been increasingly oriented around the redevelopment of big cities. This policy is associated with the use of sites and properties as collateral for bad debts, and the promotion of intensive land-use projects in city centres. The government designated a selection of sites within the centres of big cities as Emergency Redevelopment Zones (ERZs), following the model of British Enterprise Zones. Among the 34 ERZs, covering 4,749 hectares in the large cites, in central Tokyo there are 7 sites amounting to 2,375 hectares, and in Osaka City 12 sites covering 1,072 hectares. The ERZ concept represents the culmination of the deregulation process in urban planning. Normal regulations concerning land-use and building are not applicable to these exceptional zones. Developers are allowed to propose their own urban planning schemes without restriction, and development is subsidized financially by public funds. While the British Enterprise Zone policy aimed at the redevelopment of declining inner-city areas, the ERZ policy intends solely to further the recovery of the property market in big cities. Stimulated by the government's urban redevelopment policy, the 


\section{Eiji Oizumi}

construction of high-rise office buildings and condominiums has subsequently boomed in central Tokyo (Hirayama, 2005a, 2005b).

These urban policy measures have significant implications for large developers, general contractors, real-estate agents and commercial banks. In fact, the latter have benefited immensely from the booming property markets led by high-rise construction in central Tokyo, and, more belatedly, in Osaka. There has been a significant increase in bank lending for property development purposes over recent years. Indeed, whereas the total amount of newly advanced bank loans in 2004 decreased by 2.9 per cent compared to the previous year, there was a significant increase in bank lending for property development purposes. The latter amounted to $¥ 8.2$ trillion ( $£ 41$ billion) in 2004 , which represented a yearly increase of 15.3 per cent. Real-estate loans represented 19.9 per cent of total bank loans, even exceeding their share over the period of bubble economy. The rush of major banks to advance non-recourse loans to the property market is a risky business approach, but appears to be building in velocity.

It is also notable that, from the standpoint of major house-builders, the promotion of housing markets driven by high-rise building construction works puts them at a disadvantage, as they are peripheral in this sector. There are growing expectations that the government will supplement 'urban renaissance' policy with new measures aimed at promoting the participation of major house-builders in these construction activities.

\section{Housing policy advocated by pressure groups}

The emerging dynamics of the housing market offer industry pressure groups renewed opportunities to exert influence over government policies, where they seek to press for new legislation and new policy measures which will strengthen the process of housing redevelopment. A housing policy proposal titled For the Innovation of Housing and the Environment was published in 2002 by the Japan Federation of Housing Organizations (JFHO), which is an industrial association of large house-builders including the eight major companies. Building on this initiative, another proposal was introduced in 2003 by the Japan Business Federation (JBF), an important association of large companies from various industries (Sakaniwa, 2004). The most important aspects of these new policy proposals and recommendations can be described as follows.

First, a shift in the aims and objectives of housing policy is recommended. Housing policy, it is argued, should not be oriented towards the promotion of housing markets driven by mass construction. It should, rather, be geared towards mature markets characterized by active transactions involving existing stock. Housing markets with a high circulation of existing stock have grown in Western European countries and the USA, while in Japan the market of used housing is still largely underdeveloped. This policy-shift can be achieved, it 
is paradoxically suggested, through large-scale renewal investment in existing housing stock.

This reorientation of market resources brings into focus the second recommendation, which addresses the limitations and flaws in existing housing stock. There is an urgent need to provide stronger incentives for large-scale renewal investment aimed at creating earthquake-resistant housing stock. Out of the total housing stock, which exceeds 50 million units, there are 21 million dwelling units built before the enforcement of building standards for earthquake-resistant houses in 1981. The numbers of housing units which fail to meet safety standards are estimated by the MLIT to amount to as many as 14 million units.

Thirdly, there is a need for housing policy to provide stronger incentives for the development of rental housing markets. The MLIT estimates that there is a significant shortage (2.5 million units) of rental houses suitable for family households in the metropolitan areas of Tokyo, Osaka, Nagoya and Fukuoka. This shortage, it is argued, should be solved through further private investment in housing construction for rent and the conversion of disused owner-occupied houses into rented houses. It should also be addressed through the deregulation of the Housing Lease Law by relaxing the restrictions on fixed-term tenancy introduced in 2000. Incidentally, the introduction of the fixed-term tenancy was justified by the highly controversial argument that the protection of tenants' rights had impeded the supply of rental housing.

Fourthly, it is recommended that housing in areas characterized by high-density building in big cities should be redeveloped. According to the 'urban renaissance' policy, the government plans to redevelop areas in danger of natural disasters and fire $(8,000$ hectares $)$ within ten years. Half of these densely constructed but highrisk areas, covering 4,000 hectares, are located in central Tokyo and Osaka City. Thus, housing policy considers housing areas with an abundance of old and small wooden dwellings in big cities as targets for 'scrap and build' activities.

Finally, the proposals insist on the necessity of adopting the 'Basic Housing Act' as the foundation for new housing policy. The Housing Construction Plan Act of 1966, which provided the legal basis for governmental housing policies, is to be abolished and replaced with a new housing law. The new legal foundations should provide the government with strong guiding principles for the design and implementation of long-term action plans for the renewal of housing stock.

Thus, these proposals advocate a final 'scrap and build' to construct more durable, safe and quality-enhanced housing stock. While, the proposed measures aim to create a mature housing market with higher stock circulation, they will certainly create more business opportunities for the parties which stand to benefit most from these market transformations. In particular, 'scrap and build' schemes are focused on residential areas with densely concentrated building in big cities. Thus, the governmental measures together with JBF and JFHO recommendations are likely to strengthen the 'scrap and build' process in big cities on a selective 


\section{Eiji Oizumi}

basis. It is, inevitably, hard to resist the view that the ultimate objective of this 'growth coalition' is merely to implement a rescue package serving the interests of major house-builders, general contractors and developers.

Nevertheless, this 'growth coalition' includes members with differing interests. With respect to housing development in cities for instance, there are conflicting interests between house-builders and the group of general contractors and developers. It is in this context that the recommendations made by top executives of major house-building companies, not just for the improvement of the housing stock but for the creation of an amenity-rich environment and an attractive landscape, should be understood. They so far remain strong opponents of the mega-development projects by general contractors and developers.

\section{Implications: new problems for the housing market}

Despite inherently conflicting interests, this 'growth coalition' has shared needs for an expansion of the housing market. Consequently, the government's housing policy of stimulating housing construction through deregulation and privatization provides the kind of solution that serves the interests of all parties. However, this supply-side policy is likely to result in more serious problems for both urban residents and house-builders in the short as well as the long run.

Indeed, the proposals above insist that the renewal of the existing 14 million houses should be presented as a national project to create a housing stock that is disaster resistant. Conceivably, the success of this project relies on comprehensive housing policies including some housing provisions in the public sector, housing subsidies for residents, and appropriate regulation and induction. However, ongoing privatization, or more precisely marketization and deregulation, of the housing provision system make the introduction of these very subsidies and comprehensive housing policies difficult. The housing market, as I identified, is undergoing structural changes caused by economic and societal polarization, declining fertility and population and an increasingly ageing society. These demographic and social transitions are bound to increase uncertainty and risk in the housing market. With signs of polarization or segregation across housing stocks increasingly obvious, the renewal of the housing stock will only advance on an unpredictable basis.

It is also important to consider housing affordability in light of improvements in housing stock. Issues in the rented housing market have been discussed elsewhere (Horita, 2005). It should be noted that the MLIT estimate of a shortage of 2.5 million rental houses suitable for family households in the four metropolitan areas is based on a definition of such houses as ones with floor space of more than 50 square metres. With reference to this definition, in terms of the current market price of rented houses, the monthly rent for a newly built apartment house with floor space of 50 square metres can be estimated to be around $¥ 180,000$ ( $£ 900$ ) in 
the Tokyo metropolitan area in 2003. On the other hand, government investigations show that a monthly net income of working households living in privately rented houses in those areas averaged $¥ 462,000$ ( $£ 2,310$ ) in 2002 . Hence the ratio of rent to income reaches 39 per cent, greatly exceeding the standard 25 or 30 per cent generally accepted in defining housing affordability. This evidence suggests that the objective of the 'growth coalition' of ensuring an appropriate home for every household through rental housing construction is not likely to be accomplished, unless public policy measures to provide affordable houses are developed.

Seemingly, this policy targets the redevelopment of densely built-up housing areas in big cities. However, because of household affordability problems and the uncertainties inherent to the housing market, the 'scrap and build' process will be implemented on a selective, uneven and thus discriminatory basis. It is likely to result in the dispossession and social exclusion of mostly lower income classes in areas selectively designated in big cities.

Moreover, there is strong likelihood that the polarization and increasing instability of housing markets will generate problems for house-builders. First, assuming the policies being promoted by this 'growth coalition' are fully implemented, the competition among large house-builders, general contractors and developers will only grow in intensity. Indeed, they are still exposed to business risks associated with market instability and may incur high financial risks as many companies have not yet fully recovered from bad debt problems. In particular, large general contractors and developers are faced with the looming risk of over-supply in the market for high-rise housing.

Furthermore, the major house-builders which dominate the market for detached houses are being strongly challenged by the emerging franchise-groups organized by local house-builders. Finally, many small house-builders are faced with increasing competition and the prospect of extinction. This crisis largely stems from the long-lasting depression in local economies. Small house-builders are enduring strong pressure and may only survive by accepting subcontractor status, submitting to large house-builders or partnering up with organized cooperatives.

Deregulation and privatization in Japan's housing system thus constitutes a gamble on the policy of housing market stimulation through 'scrap and build' at the expense of the established housing provision system. The 'scrap and build' spiral may well escalate further, or cause more serious problems in the increasingly polarized and destabilized economy. It is possible that the policy-shift toward a mature housing market involving the improvement of housing stock may help generate an amenity-rich, landscaped environment. However, the bias in favour of the interests of suppliers suggests that such an outcome is unlikely. Housing development will be strongly restricted by market volatility.

The experience of increased volatility in the owner-occupied housing market, dominated by transactions by existing home-owners, is well documented in Britain and the USA, where, in the late 1990s, sales of existing houses amounted 


\section{Eiji Oizumi}

to 7.4 times and 3.1 times that of newly built houses, respectively. Martens (1988) identifies the role of the existing stock in the British owner-occupied housing market as well as related pitfalls. As activities in the market became dominated by transactions by existing home-owners, chains of sales became common, with more purchase and sales needing to be matched. Martens indicates that this delicate balance between purchase and sales cannot be kept without house price inflation that encourages existing home owners to trade up, and market volatility further increases as the level of new building comes to depend on house price inflation (Martens, 1988: 109-10).

Dymski (2002) analyses the 'knife-edge' balance problem of housing accumulation in the USA housing market:

Imbalances between new home values, existing home values, and household income and debt levels can slow or reverse the pace of housing accumulation ... The longer any period of successful new-home construction and sales continues, the more likely are imbalances between new and existing home-values, and between household wealth, income, and debt levels. In consequence, housing is a boom-bust industry whose downturns can undercut macroeconomic growth.

(Dymski, 2002: 70)

Instability in these mature housing markets stems not just from the market structure dominated by the behaviour of homeowners, but also from the market conditions where financial volatility, disparity of income distribution and uneven growth among cities increase. It therefore appears that the same structures of market instability will operate in Japan's housing market also, where owner-occupied houses constitute 61.2 per cent in the total stock (in 2003), compared to 67.2 per cent in Britain (in 1997) and 66.9 per cent in the USA (in 1999). Indeed, 'scrap and build' projects have to be executed under highly complex and problematic market conditions.

\section{Conclusions}

The transformations in housing construction and finance thus create new problems in the owner-occupied and rented markets, such as increases in market volatility and risk, financial discrimination and exclusion, differentiation and segregation of housing stock, and affordability problems. Privatization and deregulation policy to promote recovery in the housing market do not constitute a solution, but rather signify the start of a new set of problems. Against the background of neo-liberalization, a balanced approach in housing policy is needed, including the redefinition of; the government's and local authorities' roles, community-based housing policies following residents' initiatives, and greater partnership among 
interested parties involving small house-builders and regional banks (Oizumi, 2002b, 2005; Shiozaki, 2006).

In the context of excessive competition, further problems are emerging in the house-building industry. It has recently been exposed that a number of high-rise apartments and hotels (at least 82 structures, including 13 under construction) have been built using falsified structural-integrity data in order to reduce construction costs. At least three developers, three general contractors, a managementconsultancy company, some licensed architects, a design-engineering company and two construction-inspection companies are involved in this scandal. In addition, while the demand for house repair grows, there has been a lot of trouble caused by 'slipshod' repair works and over-charging, and homeowners' suspicions have been heightened. In the worst cases there have been injuries caused by shoddy building work, which, furthermore, have been concentrated in the households of aged people. Behind the booming development of high-rise buildings there is strong competition to reduce construction costs, which has arguably led to the undermining of safety and the trust of urban residents. Indeed, the house-building industry is facing not just market uncertainty but a crisis of confidence.

\section{References}

Ball, M. (2003) Markets and the structure of the house-building industry: an international perspective, Urban Studies, 40(5/6): 897-916.

Ball, M. and Harloe, M. (1998) Uncertainty in European housing markets, in M. Kleinman, W. Matznetter and M. Stephens (eds) European Integration and Housing Policy, London and New York: Routledge, pp. 59-76.

CSI (Council for Social Infrastructure) (2003) Toshi Saisei Bijon (The Report of the Vision for Urban Renaissance), Tokyo: Ministry of Land, Infrastructure and Transport.

Dymski, G. (2002) U.S. housing as capital accumulation: the transformation of American housing finance, households, and communities, in G. Dymski and D. Isenberg (eds) Seeking Shelter on the Pacific Rim: Financial Globalization, Social Change, and the Housing Market, New York: M. E. Sharpe, pp. 63-96.

Dymski, G. and Isenburg, D. (1997) Social efficiency and financial revolution in USA housing finance (trans. into Japanese), in H. Shibuya, S. Imura and T. Nakahama (eds) Nichi-Bei no Fukushi Kokka Shisutemu (The Welfare State Systems in Japan and the USA), Tokyo: Nihon Keizai Hyoronsha, pp. 171-205.

GHLC (Government Housing Loan Corporation) (2000) Jutaku Kin-yu Koko 50 Nen-shi (The 50 year history of the GHLC), Tokyo: Jutaku Kin-yu Fukyu Kyokai.

Hirayama, Y. (2005a) Running hot and cold in the urban home ownership market: the experience of Japan's major cities, Journal of Housing and the Built Environment, 20(1): 1-20.

Hirayama, Y. (2005b) The new dynamics of housing and urban fragmentation: feeling the effects of globalization in Japan, Paper presented to Asia-Pacific Network for Housing Research 2005 Conference, Kobe, 6-8 September.

Honma, Y. (1987) Jutaku (Housing), Tokyo: Nihon Keizai Hyoronsha. 


\section{Eiji Oizumi}

Honma, Y. (2004) Sengo Jutaku Seisaku no Kensho (Examining Housing Policy in PostWar Japan), Tokyo: Shinzansha.

Horita, Y. (2005) Contradictions in the current housing policy of Japan: with particular reference to local authority housing, Paper presented to Asia-Pacific Network for Housing Research 2005 Conference, Kobe, 6-8 September.

Itoh, M. (2002) Housing finance in Japanese financial instability, in G. Dymski and D. Isenberg (eds) Seeking Shelter on the Pacific Rim: Financial Globalization, Social Change, and the Housing Market, New York: M. E. Sharpe, pp. 150-68.

JSRI (Japan Securities Research Institute) (2000) Securities Market in Japan 2001, Tokyo: JSRI.

JSS (Jutaku Sangyo Shinbunsha) (2004) Jutaku Keizai Deta-shu 2004 (Data Book of Japanese Housing Economy), Tokyo: JSS.

KSK (Kensetsu Seisaku Kenkyusho) (2003) 21 Seiki wo ikinuku korekara no Chiiki Komuten (Report on the Situation and Future of Local House-Builders), Tokyo: KSK.

Martens, M. (1988) Owner-occupied housing: a tenure in transition, in M. Ball, M. Harloe and M. Martens, Housing and Social Change in Europe and the USA, London and New York: Routledge, pp. 87-129.

Oizumi, E. (1994) Property finance in Japan: expansion and collapse of the bubble economy, Environment and Planning A, 26(2): 199-213.

Oizumi, E. (2002a) Housing provision and marketization in 1980s and 1990s Japan: a new stage of the affordability problem?, in G. Dymski and D. Isenberg (eds) Seeking Shelter on the Pacific Rim: Financial Globalization, Social Change, and the Housing Market, New York: M. E. Sharpe, pp. 169-86.

Oizumi, E. (2002b) Restructuring of Japan's housing finance policy: should the Government Housing Loan Corporation be abolished?, Paper presented to European Network for Housing Research 2002 Conference, Vienna, 1-5 July.

Oizumi, E. (2005) Financial deregulation and the privatization of housing finance policy in Japan: an argument against abolishing the Government Housing Loan Corporation, Annals of the Economic Society Wakayama University, 9: 29-47.

Oizumi, E. and Oi, T. (2005) Japanese housing industry in transition: competition among house-builders in changing market context, Paper presented to Asia-Pacific Network for Housing Research 2005 Conference, Kobe, 6-8 September.

Sakaniwa, K. (2004) Zaikai ni yoru Jutaku Seisaku no Shihai no Kozu (Housing policy controlled by big business), Keizai (Journal of Political Economy), 106: 72-89.

Shimamoto, Y. (2005) Jutaku Soshitsu (Losing a Home), Tokyo: Chikuma Shobo.

Shiozaki, Y. (ed.) (2006) Jutaku Seisaku no Saisei (Toward a New Housing Policy), Tokyo: Nihon Keizai Hyoronsha.

Sumita, S. (2003) Maruchi-Haujingu Ron (Considerations on Multi-Housing), Kyoto: Minerva Shobo.

Yamada, Y. (2000) Jutaku Mondai to Shijo, Seisaku (Housing problems, market and policy in Japan), in M. Adachi, E. Oizumi, T. Hashimoto and Y. Yamada (eds) Jutaku Mondai to Shijo, Seisaku (Housing Problems, Market and Policy), Tokyo: Nihon Keizai Hyoronsha, pp. 1-21. 


\title{
4 Welfare regime theories and the Japanese housing system
}

\author{
Iwao Sato
}

\section{Introduction}

This chapter analyses Japan's housing system in relation to welfare regime and comparative housing system theories. Esping-Andersen has classified welfare regimes into three types: liberal, conservative and social democratic (1990, 1996, 1999). The welfare situation in Japan, however, is known to be difficult to classify in terms of this typology. In the field of comparative housing system theory, Kemeny, focusing on the place of social renting in the housing market, identifies two types of housing systems: the dualist rental system and the unitary rental market (Kemeny, 1995, 2001). Here again, however, the Japanese situation presents an anomalous case, essentially showing the features of the dualist system but not fully consistent with it.

The purpose of the present chapter is to identify the causes of Japan's resistance to these welfare regime and housing system typologies in connection with the post-war Japanese housing system. In doing so, I will take particular note of the scale of the role played by corporate housing welfare. It has been pointed out that Japan's overall system of social security and welfare services was designed to include the corporate sector as an integral subsystem, beginning in the high economic growth period of the late 1950s to 1960s (Osawa, 1994, 2005a, 2005b). In parallel to that, the corporate sector became a crucial subsystem within the post-war Japanese housing system as well.

However, the feature characteristics of the Japanese housing system have begun to falter amid the upheavals in Japan's socio-economic system since the 1990s. As Japan's economy entered a prolonged period of recession, Japanese corporations sought to enhance their business efficiency by implementing large-scale personnel cutbacks ('restructuring') and major reductions in welfare, including company housing. The destabilization of employment and the withdrawal of corporations from housing welfare are diminishing the corporate sector's role as a key subsystem within the housing system. Furthermore, since the latter half of the 1990s the national government has been vigorously advancing a campaign of neo-liberal, 
market-oriented reform politics across a broad swath of the Japanese socio-economic system, the impact of which is being felt in housing policies as well.

In this chapter I present the features of the post-war Japanese housing system as outlined and describe the transformation it has undergone in recent years. I begin by briefly describing where Japan falls in terms of welfare regime and housing system theories and confirming that the focus of the Japanese case is on housing welfare provided by the corporate sector. I then discuss the circumstances under which the corporate sector became an important subsystem within the post-war Japanese housing system, and elucidate the functions and dysfunctions of that subsystem. Further, I analyse the transformation of Japan's housing system since the latter half of the 1990s and the background to those changes. The key trends running through that transformation have been the withdrawal of corporations from the housing welfare arena and the development of market-oriented housing policies. Finally, I consider the issues surrounding the market-oriented housing system that is currently taking shape.

\section{Theoretical overview}

\section{Welfare regime typology and the Japanese case}

Although Esping-Andersen's three-type classification of welfare regimes made a tremendous contribution to the development of comparative welfare studies, further debate since then has brought to light a number of important problems associated with his typology. Two such problems are important in connection with Japan's housing system, the focus of the present chapter. One is that some cases do not fit neatly into any of the three categories of welfare regime that EspingAndersen identified (i.e. liberal, conservative and social democratic). The other is that this typology overlooks the importance of housing in welfare states.

In the context of the present chapter, the first problem that arises is the question of how to classify Japan and other East Asian countries in terms of welfare regimes. Some have attempted to resolve the question by placing East Asian countries, including Japan, the Republic of Korea (South Korea) and Taiwan, into a new category called 'Confucian welfare states' (Jones, 1993) or 'East Asian welfare regimes' (Goodman and Peng, 1986; Goodman et al., 1998). However, given the political, economic and social diversity among East Asian countries, the validity of such attempts to classify them into a single category requires further verification. While there are several perspectives on the construction of an East Asia housing model (see Ronald and Hirayama, in this volume), the view taken in the present chapter is that for the time being it is necessary to continue building up separate observations and analyses of the welfare regimes in these countries.

Esping-Andersen suggests that Japan's case is a hybrid of the liberal regime and conservative regime types $(1997,1990)$. In Japan, the social insurance system 
is divided up on the basis of occupational fields, and differences in benefits and other conditions are comparatively clear. Japan also ranks highly on social stratification indices. These points indicate the conservative features of Japan's regime. The strongly familistic nature of the Japanese case is another aspect of its conservative nature. On the other hand, Japan also shows features of the liberal type in that the market and private sector play a large role and there is minimal social welfare expenditure (see also Miyamoto et al., 2003).

As a crossing point of the liberal and conservative aspects of the Japanese regime, Esping-Andersen focuses on the provision of social benefits through the corporate sector $(1997,1990)$. This highlighting of corporate-based provision of welfare makes a valid point. It should be noted that Japanese corporations have distinctive organizational principles different from those of corporations in the West. The Japanese company is not a nexus of contracts among stockholders, managers, workers and other stakeholders; rather, it has the character of a 'welfare community' sustained by the concerted achievements of management and labour. Furthermore, as we will see again later, post-war Japanese society has made this communal bond within the company the core of its social integration (Goto, 2001). The role of this specific kind of corporation apparently has given Japan's welfare regime its distinctive features, and the aim of the present chapter is to analyse those features in connection with Japan's housing system.

\section{Housing system typology and the Japanese case}

Although housing is, along with social security, health and education, one of the four main pillars of the welfare state, it has long been neglected in comparative welfare research (Kemeny, 1995, 2001). According to Kemeny, the extent to which housing is a pillar of the welfare state depends to a considerable degree on how the provision of housing is organized. Kemeny notes that two opposing political 'strategies' or 'philosophies' have developed in regard to the state's role in the provision of housing $(1995,2001)$.

In one approach, the state takes upon itself the direct responsibility of providing rental housing for households in need. To this end, non-profit (social) rental housing is organized in the form of a state or local government monopoly. As far as possible, the social renting sector is prevented from competing with private profit-seeking housing companies by hiving it off from the market into a command-economy social rental housing sector. Access is in terms of 'need'. The result is a dualist rental system in which two distinct types of rental tenure are created, corresponding to a 'public' command-economy sector and a 'private', and largely unregulated, rental market.

In the other approach, the state is not a major provider of housing itself or, if it is, access to such housing is not limited to households in need. Instead, non-profit rental housing is encouraged to compete with for-profit rental housing on the open 
market for tenants. Social rental housing can thereby set standards, ensure that all households have security of tenancy and competitively hold rents down. The result is that the legal distinction between for-profit and non-profit (social) housing is minimized and a unitary rental market is encouraged to emerge.

While noting certain variations from one country to the other, Kemeny finds the dualist housing system typified in Anglo-Saxon countries, and also includes in the dualist category most Southern European countries as well as a few Northern European countries (Norway, Finland and Iceland). Countries exemplifying the unitary rental market, meanwhile, include Germany, Denmark, Sweden and the Netherlands. Kemeny points out that whether a country has a unitary rental market or a dualist rental system may be explained in terms of corporatist versus twoparty political systems. Dualist systems tend to be found in societies with twoparty systems while unitary markets tend to be found in societies with corporatist political structures.

Furthermore, Kemeny notes that countries with command-type public rental sectors (dualist) tend to have a higher proportion of owner occupation than countries with integrated (unitary) rental markets because alternatives to owner occupation are effectively precluded from the available range of choices. If open access to public renting is denied as a realistic alternative to middle-income households, while the profit-dominated rental market only offers either highquality housing with high rents and insecurity of tenancy or low-rent housing with security of tenancy but at low quality, then the only alternative remaining is owner occupation. As a result, countries with a dualist rental system have high rates of owner occupation (see Table 4.1).

In many respects Japan shows features of a dualist system. Social rental housing is provided in the form of government-managed housing (public housing) for needy households; the social rental housing sector is separated from the rental housing market; and, since rental housing is not a realistic option for middleincome households seeking good-quality and affordable housing, the rate of home ownership is very high (see Table 4.1). On the other hand, however, closer examination shows that Japan's housing system has unique features in relation to Kemeny's typology. Specifically, company housing, or housing that private corporations provide to their employees, accounts for a significant share of overall housing in Japan, and the corporate sector thus constitutes an important subsystem within the Japanese housing system.

The magnitude of the role played by the corporate sector in post-war Japanese society makes Japan an awkward case for both the welfare regime and housing system typologies. How did this system of company-based housing welfare take shape in the context of post-war Japan's housing system? What functions and dysfunctions has this kind of housing welfare shown? And how is it evolving today? 
Table 4.1 Comparison of housing tenure

\begin{tabular}{lllll}
\hline Country & $\begin{array}{l}\text { Owner } \\
\text { occupation } \\
(\%)\end{array}$ & $\begin{array}{l}\text { Private } \\
\text { rental }(\%)\end{array}$ & $\begin{array}{l}\text { Public rental } \\
(\%)\end{array}$ & $\begin{array}{l}\text { Company } \\
\text { rental (\%) }\end{array}$ \\
\hline $\begin{array}{l}\text { 1 Dualist } \\
\text { housing systems }\end{array}$ & & & & - \\
England & 66.0 & 7.0 & 27.0 & - \\
Ireland & 78.0 & 9.0 & 14.0 & - \\
USA & 70.0 & 25.0 & 5.0 & 5.0 \\
Japan (1993) & 59.8 & 26.4 & 7.1 & 3.1 \\
Japan (2003) & 61.2 & 26.9 & 6.6 & - \\
2 Unitary & & & & - \\
housing systems & & 38.0 & 25.0 & - \\
Germany & 37.0 & 25.0 & 18.0 & - \\
Denmark & 32.0 & 20.0 & 23.0 & \\
Sweden & 40.0 & & & \\
\hline
\end{tabular}

Source: Kemeny, 2001; figures for Japan provided by author.

\section{Japan's post-war housing system and corporate housing welfare}

\section{Basic features of Japan's post-war housing system}

Housing in Japan was devastated during the Second World War, by the end of which (August 1945), according to government estimates, the nation had a shortage of some 4.2 million homes. How to fill that gap was the most pressing challenge facing housing policy in post-war Japan. To meet the challenge, a number of systems were instituted one after another in the early 1950s, notably a system for local governments to acquire national government subsidies for construction of public housing (kouei jutaku) (launched in 1951); a system under which the Japan Housing Corporation (Nihon Jutaku Koudan) carried out broadbased and large-scale housing construction projects (1955); and a system whereby the Government Housing Loan Corporation (Jutaku Kinyu Kouko) provided long-term, low-interest loans for private housing construction (1950). These three systems became the three main pillars of Japan's post-war housing policy through a class-based division of roles: local government public housing supplied low-cost rental housing to the low-income class; the Japan Housing Corporation supplied rental and tract housing to the middle class; and the Government Housing Loan Corporation provided public funding mainly for the construction of privately owned homes for the more affluent middle class. 
This post-war Japanese housing policy shows a number of features (Watanabe, 1962; Harada, 1985; Sato, 1999; Hirayama, 2003a). First, a basic premise of the policy was the principle of 'self-help', that is, that the private sector would construct housing on its own initiative and strength.

Second, and as a corollary of the first feature, the scope of the government's role in housing welfare was kept to the minimum necessary. This feature was most prominent in the way public housing was understood in post-war Japan: as a Ministry of Construction official in charge of establishing the public housing system put it at one Diet meeting, public housing was regarded as purely a stopgap measure until private housing construction was firmly back on the recovery track (cited in Watanabe, 1962); and on that basis the number of public housing construction projects was kept to the minimum necessary. Table 4.2 shows a comparison of the shares accounted for by social rental housing construction in overall new housing construction in England and Wales, Germany (former West Germany) and Japan after the Second World War. The comparison shows that in the 1950s, when the housing situation in all of these countries was in serious crisis, whereas public housing in England and Wales and social housing (sozialer Wohnungsbau) in Germany made up 64.0 per cent and 45.8 per cent, respectively, in Japan public housing (i.e. local government or public corporation-managed housing) accounted for only 18.4 per cent.

Third, Japan's rent allowance system leaves much to be desired. There is a system for rent reduction or exemption under special circumstances in public housing, and a housing allowance as part of the livelihood protection measures provided under the system of public aid (seikatsu hogo). But these systems apply only to limited areas, and Japan has no general rent assistance like Britain's housing benefits or Germany's Wohngeld programmes. Given the scarcity of government-supplied social rental housing, many people had little choice but to

Table 4.2 Share of construction of social rental housing to total new housing construction

\begin{tabular}{llll}
\hline Year & $\begin{array}{l}\text { England } \\
\text { and Wales } \\
\text { (public } \\
\text { housing) }\end{array}$ & $\begin{array}{l}\text { Germany } \\
\text { (social } \\
\text { housing) }\end{array}$ & $\begin{array}{l}\text { Japan (public } \\
\text { housing owned by } \\
\text { local authority and } \\
\text { public corporations) }\end{array}$ \\
\hline $1945-49$ & 76.8 & - & 7.4 \\
$1950-59$ & 64.0 & 45.8 & 18.4 \\
$1960-69$ & 43.2 & 28.8 & 9.1 \\
$1970-79$ & 18.0 & 19.5 & 7.2 \\
$1980-89$ & 3.5 & 11.6 & 4.3 \\
\hline
\end{tabular}

Source: Sato, 1999: 304.

Note: ${ }^{a}$ Former West Germany. 
rely on private rental housing, but in the absence of a general programme of rent assistance, a dilemma arose: good-quality private rental housing meant heavy rent burdens, but lowering construction costs to meet tenants' limited rent-payment capacities meant private rental housing of poor quality. The latter option became the prevailing trend, with the result that most private rental dwellings were small and shoddy.

A fourth feature of Japan's post-war housing policy is that, within the context just outlined, the government's only concentrated infusion of public funds for housing was its assistance for home ownership. From the 1950s on, the government pursued a vigorous policy of helping the middle class to acquire their own homes. The principal measures adopted to that end were long-term, lowinterest loans provided by the Government Housing Loan Corporation and tract housing supplied by the Japan Housing Corporation. The government's proactive policy for home ownership was aimed at cultivating and stabilizing the middle class as the focus of Japan's post-war economic recovery and social reconstruction (Hirayama, 2003b). Assistance for home ownership has remained a corner stone of the government's housing policy to this day. Given the scarcity of social rental housing and the poor quality of private rental housing, the government's vigorous support for home ownership has led to a high rate of home ownership in Japan, at around 60 per cent (see Table 4.1).

Because social rental housing has been provided mainly in the form of public housing (some through the Japan Housing Corporation), the social rental housing sector has been clearly differentiated from the private rental housing market. At the same time, the scarcity of social rental housing and the poor quality of private rental housing have had the effect of boosting home ownership among the middle class and thus raising Japan's overall home ownership rate. In these respects, among others, Japan's post-war housing policy has given Japan's housing system the features of what Kemeny calls the dualist system. Within that context, another key feature of Japan's post-war housing system is that, with companies actively providing housing welfare for their employees, the corporate sector has become an important subsystem within the overall housing system.

\section{Corporate housing welfare as a subsystem of the housing system}

Generally speaking, the corporate sector has played a crucial role in improving employee welfare in Japan (company welfare) (Fujita and Shionoya, 1997; Tachibanaki, 2001, 2005), and company-provided housing welfare has been one of the most important elements of that trend. Japanese corporations have typically provided their employees with low-cost rental housing (company housing, kyuyo jutaku or shataku) as well as financial assistance towards owning their own homes 
(Kaneko, 1991; Fujita and Kojima, 1997; Shinkai, 1997; Tachibanaki, 2001, 2005).

Company housing first appeared in Japan with the emergence of the textiles and mining industries during the burgeoning of modern industry in the late nineteenth century. Companies in those industries provided their employees with housing (dormitory-style ryo) near their places of work. Generally speaking, however, until the Second World War most workers lived in regular private rental accommodation (Ariizumi, 1956).

The catalyst for the dramatic expansion and improvement of corporate housing welfare came during the Second World War, when, to ease the strain on worker housing in urban heavy industry zones (the centres of the war industry), many companies began providing housing for their employees. After the war, corporate housing programmes were further expanded and popularized to fill what was by then a serious housing shortage. In 1948, company housing accounted for 5.8 per cent of total housing stock, and that share subsequently rose even higher, to 6.7 per cent in 1958 and 7.0 per cent in 1963 (Housing Survey of Japan). From the late 1960s on, Japanese corporations also began actively helping employees to acquire their own homes by providing them with low-interest loans, interest subsidies and other assistance towards home ownership. In this way, the corporate sector became an important subsystem of Japan's post-war housing system (Kaneko, 1991; Fujita and Kojima, 1997; Shinkai, 1997; Tachibanaki, 2001, 2005).

The expansion of corporate housing welfare in Japan can be seen in terms of each of the main protagonists behind it, namely, the government, the corporate sector and labour unions.

In terms of its policy of promoting housing construction through self-helptype construction activity by the private sector, the government was happy to see corporations building as many homes as possible with private funding (Watanabe, 1962; Harada, 1985). In 1953 the government opened the way to Government Housing Loan Corporation financing for company housing construction, and throughout the economic boom period of the late 1950s and 1960s a lot of company housing was built with such loans. Moreover, corporate support for employee home acquisition also meshed well with the government's policy of nurturing and stabilizing the middle class through home ownership. For this reason, the government instituted generous tax breaks related to the low-interest loans and interest subsidies that companies provided for home acquisition (Kaneko, 1991; Shinkai, 1997).

In the corporate sector, meanwhile, the limited number of public housing projects being constructed despite the serious post-war housing shortage meant that companies needed to implement their own housing policies for their employees (Ariizumi, 1956). Whereas Europe around the same time saw vigorous construction of social rental housing, with governments playing a leading part in the recovery of the housing system, in Japan the corporate sector came to assume 
that role in the government's stead. Even after the serious housing shortage of the immediate post-war years had been significantly alleviated, Japan's corporate sector continued and even enhanced its provision of housing welfare to employees. This was because doing so brought benefits to corporations themselves, including the securing of a quality labour force, the improved productivity that came from giving employees a good work environment, employee loyalty to the company and good labour-management relations (Shinkai, 1997; Tachibanaki, 2001, 2005).

Another factor that must not be overlooked is that labour unions were also actively involved in corporate efforts to provide housing welfare. Because labour unions in Japan were organized separately on an individual company basis, union demands regarding housing were made at the level of labour negotiations within each company and were aimed at improving the housing welfare provided by the company. The provision of company housing was thus in fact also a union demand; furthermore, when in the late 1960s corporations began actively helping employees to become homeowners, labour unions eagerly embraced that trend as well.

This stance of the labour unions had an important impact on the formation of the Japanese post-war housing system, beyond simply that the unions and other labour powers embraced corporate housing welfare. In post-war Europe, the elements that called on the government to spearhead housing policies, such as for mass construction of social rental housing, were nationally organized labour movements led by industry-wide labour unions, together with the social democratic political parties they backed. In Japan, by contrast, labour unions did not influence the government's housing policy through such macro-strategies at the level of national, general housing policy. Ohmoto (1991) relates the retrospective account given by a key figure in a national association of labour unions:

Given that most labour unions were based within individual corporations, housing issues were resolved to some extent by the fact that corporations - mainly large, stable corporations - provided company housing or provided home loans using company reserve funds. In other words, labour unions could get things done without orchestrating unified demands through national centres. This was why, on the one hand, labour unions did not influence the government's housing policy at the national level, and also why, on the other, individual labour unions took a positive stance toward the housing welfare that companies provided.

(Cited in Ohmoto, 1991: 806)

A distinctive feature of Japanese corporations is the cooperative relationship maintained between management and labour at the individual company level. Goto (2001) characterizes social integration in post-war Japan as corporatecentred integration, in contrast to the welfare state integration seen in Europe. This 
Japanese form of social integration is based on voluntary acceptance of a logic whereby workers enlarge the overall pie by striving to improve the performance of their company, secure for themselves a larger share of that pie by prevailing in competition with other workers to contribute to the company, and so improve their own livelihoods. With workers thus regarding the company as a performance/ welfare community, conflicts of interest between labour and management receded into the background (Watanabe, 1990; Osawa, 1994; Goto, 2001). Shinkawa (1993) points out that, given these features of labour relations and labour unions within companies, there was little likelihood of workers in post-war Japan uniting as a distinct class and driving the development of a social-democratic welfare state.

Corporate housing welfare compensated for the meagreness of social rental housing supplied by the government. However, the scarcity of governmentsupplied social rental housing was itself a result of Japan's corporate-centred social integration, which fostered labour's demands for housing at the micro-level of individual companies but meant that effective influence was not exerted on the government at the macro-level of overall housing policy.

\section{Dysfunction of corporate housing welfare}

While there is no doubt that corporate housing welfare has played a crucial role as a subsystem of housing security, at the same time it has also brought with it a number of problems.

One is the welfare gap between corporations of different sizes. Generally speaking, large corporations offer generous welfare packages while small and medium-size companies provide only meagre ones, and housing welfare is one area in which this gap is particularly noticeable. Larger corporations tend to own more housing and in more desirable locations and to be more generous in their assistance towards employees buying their own homes. Figure 4.1 shows a comparison of monthly housing-related welfare expenditure per employee among corporations of different sizes. We see a marked trend of higher per-head expenditure the bigger the corporation. Larger corporations generally provide higher salaries, and on top of that their employees generally enjoy more favourable housing welfare (Shinkai, 1997; Tachibanaki, 2005).

Another problem is the gap in welfare between regular and non-regular employees. Japan's labour force includes many part-time, temporary and other non-regular workers. Particularly amid the prolonged recession that began in the 1990s, many companies have shifted towards downsizing their regular staff (restructuring) and replacing them with non-regular employees. As a result, nonregular employees now account for some 30 per cent of the total workforce and around half of all working women. Meanwhile, a marked gap exists between regular and non-regular employees in terms of corporate welfare. In many cases, 


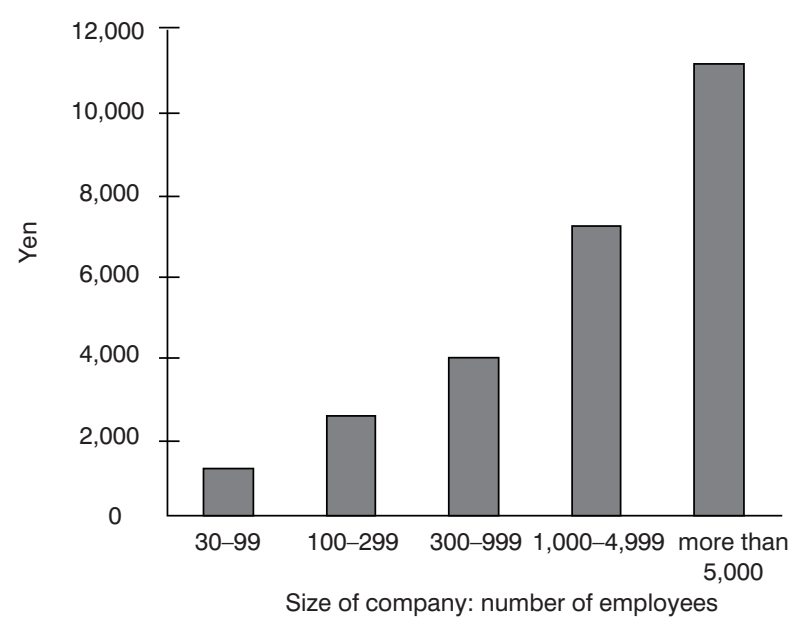

4.1 Company provision costs related to housing (monthly amount per employee)

Source: Ministry of Health, Labour and Welfare, General Survey of Working Conditions 2002.

only regular employees qualify for company housing or for company assistance toward home ownership. Corporate housing welfare has thus led to considerable inequality between regular and non-regular employees (Tachibanaki, 2005).

A third problem is that the system of corporate housing welfare gives priority to male householders. In many cases, being the head of one's household is one of the conditions of eligibility for company housing. Given that most household heads are men, the company housing system has thus an inherent gender bias. In 2002 a Cabinet Office investigative committee conducted a survey in which it analysed links between company housing systems and the proportions accounted for by women among corporate employees and managerial staff. The survey found that implementation of company housing systems was more prevalent the smaller the ratios of female employees and female managers, and interpreted this as indicating that company housing is being provided primarily to men who are heads of their households (Cabinet Office, 2002). Furthermore, given that most non-regular employees are women, the aforementioned inequality between regular and non-regular employees in terms of eligibility for corporate housing welfare overlaps with the gender disparity. Viewed from standpoint of gender, corporate housing welfare is thus heavily marked by the 'male breadwinner' paradigm (Osawa, 1994, 2005a, 2005b). 


\section{Transformation of the Japanese housing system since the 1990s}

\section{Withdrawal of the corporate sector from housing welfare}

The Japanese housing system described above has been undergoing a marked transformation since the 1990s. One major change is that private corporations, which previously constituted an important subsystem of the housing system, are withdrawing from the housing welfare field. Another is that the thrust of the government's housing policy has turned sharply towards the formation of a more market-oriented housing system.

In the 1990s, the Japanese economy entered a period of prolonged recession. As economic growth slowed considerably, many corporations, struggling now for their very survival, carried out large-scale personnel restructuring and downsizing. This extensive restructuring, together with corporations' declining capacity to absorb new entrants to the labour force, pushed unemployment to over 5 per cent and led to a net decline in the total labour force population for the first time in the 40 years since the high economic growth period of the 1960s. At the same time, the trend of cutting back on regular staff and replacing them with part-time, temporary, and other non-regular employees is becoming increasingly pronounced. The share of corporate employees made up by non-regular employees rose from 20.2 per cent (males: 8.8 per cent; females: 38.1 per cent) in 1990 to 30.4 per cent (males: 15.6 per cent; females: 50.6 per cent) in 2003 (Nakamura, 2005). Japanese companies of the post-war era established a distinctive standard of providing employees with long-term, stable employment, but these recent changes have rocked the post-war employment system (Nitta, 2003). They have also impacted in important ways on corporate housing welfare.

One of the effects is that the scope of corporate housing welfare coverage is shrinking. People typically eligible to enjoy the benefits of corporate housing are those employed by companies as regular, full-time employees; but as a result of management rationalization measures in the form of drastic personnel cutbacks and the shift from regular to non-regular employees, the beneficiaries of corporate housing welfare are steadily decreasing in number. Moreover, when employees who have been living in company housing are retrenched, this means they lose their homes at the same time that they lose their jobs. Because it is intertwined with the Japanese employment system, the system of corporate housing welfare thus leads to loss of housing along with loss of employment (income). This harsh aspect of the system became increasingly apparent in the 1990s.

Another effect of the changes is the growing trend of corporate withdrawal from the field of housing welfare itself. According to a survey conducted by the Ministry of Health, Labour, and Welfare in 2002, of all the surveyed corporations that had been providing employees with company housing or assistance towards home ownership in 1997, the ratios of those that reduced such measures in the 
five years from 1997 to 2002 was 20.9 per cent for company housing and 12.8 per cent for home ownership assistance. Particularly notable is that the trend of curtailing company housing and assistance for home ownership is prominent even among large corporations, which in the past had been generous in providing their employees with housing welfare (see Figure 4.2). The circumstances behind this trend include demands on corporations to rationalize their business operations, the selling off of corporate-owned housing and land as real-estate assets to reduce debts, and major revisions of the employment system. As a result, the share of total housing stock accounted for by company housing has dropped sharply since the 1990s, down to 3.1 per cent by 2003 (Housing and Land Survey of Japan).

Though previously an important subsystem within Japan's post-war housing system, corporate housing welfare is thus steadily retreating into a narrower and narrower functional range.

\section{The state's role gets even smaller: market-oriented housing policy}

As already mentioned, the role played by the state in housing welfare in Japan has long been a minor one, but a significant feature of housing welfare developments in the decade and a half since 1990 is that the state's role has diminished even further. Specifically, the system previously sustained by public housing, the Japan Housing Corporation, and the Government Housing Loan Corporation - the three pillars of post-war housing policy - has begun to unravel.

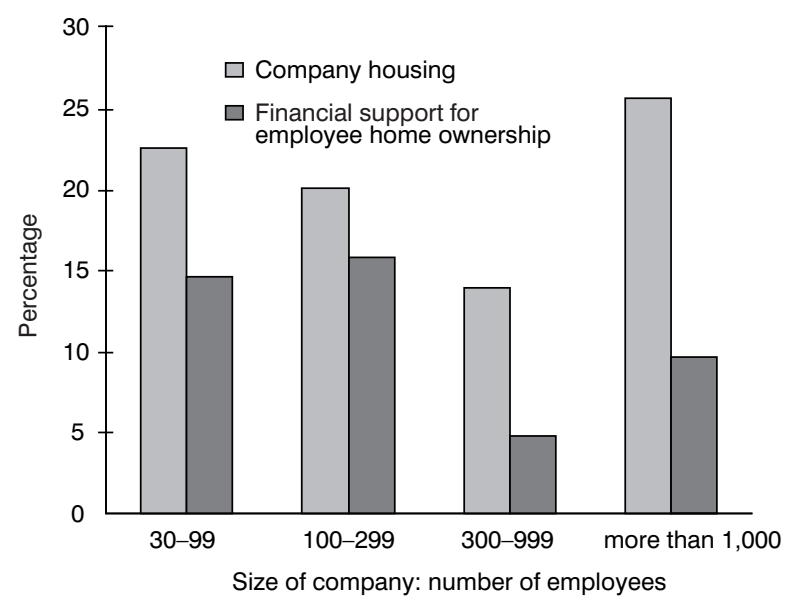

4.2 Ratio of number of companies that reduced housing services 1997-2002 Source: Ministry of Health, Labour and Welfare, General Survey of Working Conditions 2002. 
Looking first at public housing, we find that the number of new construction projects has dropped sharply in recent years. The number of public housing construction projects was 51,030 in 1995 but by 2004 had dropped to 21,278 (see Figure 4.3). The stock of public housing was far from adequate in the first place, and with little prospect of new construction the government in recent years has increasingly emphasized the need for 'fairness' and 'efficiency' in the management of existing public housing. Specifically, this means 'tightening up the management of public housing so that it is provided appropriately to people in genuinely critical need of housing' (Ministry of Land, Infrastructure, and Transport, 2003). The categories mentioned as 'people in genuinely critical need of housing' include the elderly, the disabled, victims of domestic violence, the homeless, singleparent households, and foreign nationals. Meanwhile, for people who do not fall into any of these special categories, the income levels determining eligibility for public housing are gradually being lowered, resulting in a marked shrinking of the socio-economic class to which public housing is available. At the same time, there has been a strengthening of measures concerning people whose incomes rise above the eligibility ceiling after they have already entered public housing, such as charging them additional rent or requiring them to move out. Public housing in Japan already had a residual quality in that the stock of such housing has always been too small to cover a broad class spectrum of the population; but with the developments of the 1990s - the lowering of the income threshold for eligibility for public housing (i.e. shrinking the proportion of the population covered) and the increasing specification of categories of eligible people - public housing has become even more residualized (Hirayama, 2002, 2003a).

The second pillar of housing welfare policy is the Japan Housing Corporation. In 1981 this body was reorganized as the Housing and Urban Development

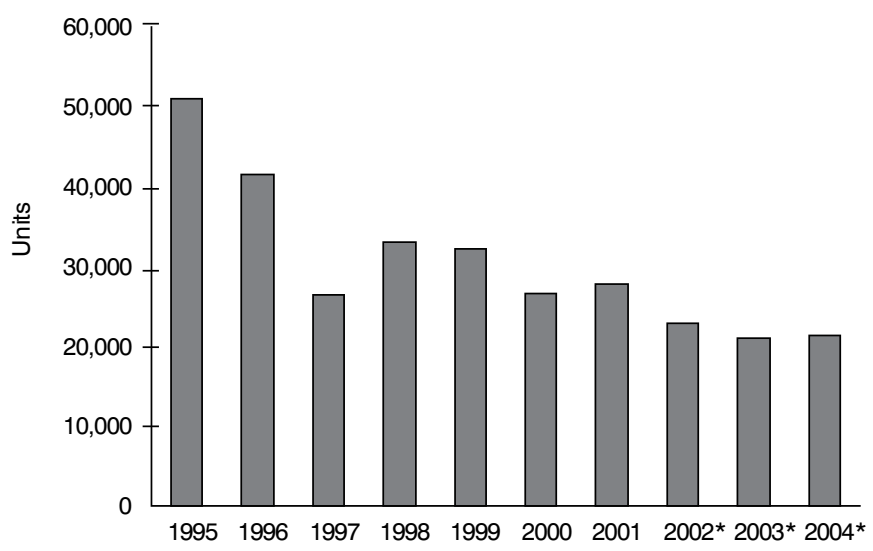

4.3 Construction of public housing 1995-2004

Source: Ministry of Land, Infrastructure and Transport, Housing Bureau

* Estimated 
Corporation (Jutaku Toshi Seibi Koudan), tasked with developing new, large-scale housing projects in addition to providing housing. In 1999 it was renamed the Urban Development Corporation (Toshi Kiban Seibi Koudan), and in 2004 further reforms greatly reduced its functions and it was reborn as the Urban Renaissance Agency (Toshi Saisei Kikou). Instead of undertaking urban development itself, the agency's role was now limited to supporting redevelopment projects carried out by the private sector. In the area of housing provision, the agency has withdrawn from tract housing projects, has stopped construction of new rental housing, is selling as much of its existing housing stock as possible to the private sector, and wherever possible is outsourcing the management of the remaining buildings to private companies.

Furthermore, as part of its efforts to promote a market-based home loan system, the government has decided to abolish the Government Housing Loan Corporation, a key player in home financing in post-war Japan, at the end of March 2007 (see Oizumi, in this volume). Although part of the organization will continue in the form of a new body called the Housing Loan Support Agency (Jutaku Kinyu Shien Kikou), the functions of the latter will be greatly reduced. Instead of providing housing loans directly, it will focus on providing support for the securitization of real estate (i.e. measures to facilitate financing through the securitization of home loans by private financial institutions).

In these ways, public housing is taking on a more residual character and the role of the public sector in providing housing and home loans is diminishing considerably. Underlying this housing policy of the present government is its current programme of neo-liberal reform politics. Since the latter half of the 1990s, the government, led by the Liberal Democratic Party, has forged ahead with a series of reforms, including deregulation, privatization and administrative reforms (reduction and streamlining of government functions), over a broad spectrum of policy areas. This reform campaign has gathered particular momentum under the leadership of Prime Minister Jun'ichiro Koizumi, who assumed the prime ministership in 2001 (Tokyo University, Institute of Social Science, 2006; Noble, 2006). The waning of the state's role in the housing system and the increased emphasis on the role of the market are among the main effects these reforms have had in the area of housing policy.

The key question here is whether or not these modifications to the housing system help to improve housing welfare for the society at large. While we must avoid jumping to any hasty conclusions in this regard, it is important to bear the following points in mind. First, corporate housing welfare, which, as we have seen, was a crucial mechanism compensating for the meagreness of the state's role in Japan's post-war housing system, no longer performs as effectively as it previously did. If corporate housing welfare previously made up for the scantiness of state-supplied public housing, then what is needed now that the corporate sector is pulling out of the housing welfare field should be an expansion of the state's 
role. Instead, what actually emerged in the 1990s was a situation in which the corporate withdrawal and the shrinking of the state's role both proceeded at the same time.

Second, further residualization of public housing and the decline of company housing are serving to increase the roles played by home ownership and private rental housing. Let us consider home ownership first. Amid the economic slump Japan has been in since the 1990s, the risk factors involved in buying a home have increased. The number of households unable to repay housing loans due to recession-related job loss or stagnant wage growth, among other reasons, has risen sharply. From 1995 to 2002, the number of Government Housing Loan Corporation loans with repayments in arrears by six months or more jumped from 14,205 to 42,333 . Furthermore, one result of the fall in housing prices is that home ownership increasingly figures as a major capital loss in household budgets (i.e. the remaining debt of the home loan is far greater than the asset value of the home). Whereas in post-war Japan the government strove to nurture and stabilize the middle class by promoting home ownership, in the 1990s home ownership itself became a destabilizing factor in the lives of the middle class (Hirayama, 2003b).

The third point concerns the role of private rental housing. While reducing its own role in the housing system, the government is hoping to invigorate that of the private rental market. Here too, however, we find a situation of increasing destabilization of rental tenancy due to the easing of regulations on rental housing. In 1921, legislation was passed in Japan that regulated rental contracts so as to protect tenants (the Rent Act of 1921), and in 1941 such regulations were strengthened. Under these regulations, in order to terminate rental contracts landlords must have 'justifiable grounds' for doing so, such as reallocating a dwelling for their own or their family's use, and rent increases are limited to standards of 'reasonable rent' (not rent control, but rent regulation). The courts determine whether or not rent is reasonable and whether or not the landlord has justifiable grounds for terminating a rental contract. Through strict application of the regulations, the courts have played a crucial role in safeguarding tenant occupancy. The stable persistence of rental contract regulation has been an important feature of Japanese housing law, and such regulation has constituted the most effective safety net for tenants (Sato, 1999).

In December 1999, however, a government initiative led to the enactment of the Law on Special Measures to Promote the Supply of Quality Rental Housing (Ryoshitsu na Chintai Jutaku tou no Kyoukyu no Sokushin ni Kansuru Tokubetsu Sochi Hou), which provided for major exceptions to traditional rental regulations. The new law allows for rental contracts in which the landlord and tenant agree, under certain conditions, to eliminate security of tenancy on the understanding that the rental contract will automatically terminate at the end of the rental period. The government's intention in introducing this law was to increase supply of quality 
rental housing by easing regulations on rental contracts, but it has attracted fierce criticism from people who point out that, given the inequality in bargaining power between landlords and tenants, in practice the new system works solely in favour of landlords and could result in destabilization of tenant occupancy (Harada, 2000; Morimoto, 2000). This law is typical of the neo-liberal, market-oriented housing policy the government has been pursuing since the latter half of the 1990s.

\section{Conclusion}

Since the 1990s, the corporate sector has been withdrawing from the housing welfare arena in Japan, and the government's role in housing welfare has also been diminishing as a consequence of its market-oriented housing policy. Against this backdrop I would like to consider two questions: Is the corporate withdrawal from housing welfare only a temporary phenomenon? In what direction is Japan's housing system likely to evolve from now on?

The slowdown of the Japanese economy has certainly been a major factor behind the corporate sector's withdrawal from housing welfare. If, then, the Japanese economy picks up again, as it is now finally showing signs of doing, does that mean Japanese corporations will return to the housing welfare arena and that the corporate sector will once again become a key subsystem within the housing system? In my view, this is unlikely. The context in which Japanese corporations previously took on such a major role in the housing welfare arena included the Japanese-style employment system, characterized by career-long employment and promotion by seniority. But that employment system has been deteriorating over the past 15 years and will not easily be restored to its former prominence. Considering the changes that have taken place in the employment system, as well as the pressure of international competition, which is expected to become even more intense in the coming years, the waning of the corporate sector's role in housing welfare would seem to be irreversible.

We must also bear in mind that the post-war Japanese housing system in which the corporate sector played such an important part was itself problematic in that it entailed a number of disparities and inequalities, such as between large and small companies, between regular and non-regular employees, and between male and female employees due to the bias towards male householders.

So how is Japan's housing system likely to develop from now on? One option that deserves careful consideration is that of an expansion of the role of state in housing welfare. Specifically, various lessons can be drawn from the past experience and underlying philosophy of countries with unitary housing systems, whereby the stock of quality rental housing builds up as the state assumes responsibility for expanding and popularizing the non-profit (social) rental housing sector and integrating it with for-profit rental housing. A crucial 
element in such an approach would be the introduction of the kind of universal rent assistance programmes common among European countries. But reorienting Japan's housing system in this way would require more than simply expanding the state's role so as to offset the decline in housing welfare provided by a corporate sector that previously fulfilled that role in the government's stead. Rather, a more positive and meaningful approach would be to acknowledge that the provision of housing welfare by private corporations entails serious dysfunctions, and to create instead a system for adequate housing welfare without relying on the corporate sector.

This is not, however, the thrust of current government policy. Instead, the government is moving towards creating a more market-oriented housing system while paring down its own responsibility for housing welfare to a scale even smaller than in the past. The current situation is one of increasing deregulation/ liberalization of the rental system and increasing residualization of public housing on the basis of the clear-cut separation of social rental housing (public housing) from private rental housing. In these respects, Japan's housing system appears to be evolving in the direction of a pure dualist type.

Under this present system, people have little choice but to procure housing on the commercial housing market. However, there is no government assistance for them in that market, as no rental assistance of the kind seen in Europe is available, and the measures for security of tenancy that until recently constituted the most important safety net for tenants are being weakened. Meanwhile, it remains uncertain whether or not the supply of quality commercial rental housing that the government hopes to generate through rent deregulation will in fact materialize. The 'social divide', or widening gap between the haves and have-nots, is arousing considerable debate in Japan today (see e.g. Tachibanaki, 1998; Sato, 2000; Otake, 2005; Shirahase, 2006). It is doubtful whether the market-oriented housing system that the government is working to create will be able to provide quality, affordable housing to a broad cross-section of the Japanese people in the age of inequalities.

\section{References}

Ariizumi, T. (ed.) (1956) Kyuyo Jutaku Kouei Jutaku no Kenkyu (Study of Corporate Housing and Public Housing), Tokyo: Tokyo University Press.

Cabinet Office, Danjo Kyodo Sankaku Kaigi Eikyo Chosa Senmon Iinkai (2002) Koyo Sisutemu ni kansuru Anketo Chosa Hokoku-sho (Report of the Survey on the Employment System), Tokyo (unpublished).

Esping-Andersen, G. (1990) The Three Worlds of Welfare Capitalism, Cambridge: Polity Press.

Esping-Andersen, G. (ed.) (1996) Welfare States in Transition: National Adaptations in Global Economics, London: Sage.

Esping-Andersen, G. (1997) Hybrid or unique? The Japanese welfare state between Europe and America, Journal of European Social Policy, 7(3): 179-89. 
Esping-Andersen, G. (1999) Social Foundations of Post-Industrial Economies, Oxford: Oxford University Press.

Fujita, Y. and Kojima, S. (1997) Kigyo-nai fukushi to shakai hosho: kenkyu no kadai (Employee benefits and social security: the subject of the research), in Fujita and Shionoya, 1997: 1-14.

Fujita, Y. and Shionoya, Y. (eds) (1997) Kigyo-nai Fukushi to Shakai Hosho (Employee Benefits and Social Security), Tokyo: Tokyo University Press.

Goodman, R. and Peng, I. (1996) The East Asian welfare states: peripatetic learning, adaptive change, and nation-building, in G. Esping-Andersen (ed.) Welfare States in Transition: National Adaptations in Global Economics, London: Sage, pp. 192-224.

Goodman, R., White, G. and Kwon, H. (eds) (1998) The East Asian Welfare Model: Welfare Orientalism and the State, London: Routledge.

Goto, M. (2001) Shushuku suru Nihon-gata 'Taishu' Shakai: Keizai Gurobarizumu to Kokumin no Bunretsu (The Shrinking Japanese 'Mass-Society': Economic Globalization and the Splitting Nation), Tokyo: Junpō-sha.

Harada, S. (1985) Sengo jutaku housei no seiritsu katei (The establishment process of housing laws in post-war Japan), in Institute of Social Science, Tokyo University (ed.), Fukushi Kokka, vol. 6, Nihon no Shakai to Fukushi (The Welfare State, vol. 6, Japanese Society and Welfare), Tokyo: Tokyo University Press, pp. 317-96.

Harada, S. (2000) Teiki syakuya seido donyu hou no mondaiten (Problems of the law which introduces the system of the regular tenancy), Houritsu Jihou (Journal of Legal Affairs), 72(2): 1-3.

Hirayama, Y. (2002) Kouei jutaku seido no ichi to seisitsu ni tsuite (On the stand and character of the Japanese public housing system), Toshi Seisaku (Urban Policy), 109: $37-48$.

Hirayama, Y. (2003a) Housing and social inequality in Japan, in M. Izuhara (ed.), Comparing Social Policies: Exploring New Perspectives in Britain and Japan, Bristol: Polity Press, pp. 151-71.

Hirayama, Y. (2003b) Home ownership in an unstable world: the case of Japan, in R. Forrest and J. Lee (eds) Housing and Social Change: East-West Perspectives, London: Routledge, pp. 140-61.

Jones, C. (1993) The Pacific challenge: Confucian welfare state, in C. Jones (ed.), New Perspectives on the Welfare State in Europe, London: Routledge, pp. 198-217.

Kaneko, M. (1991) Kigyo shakai no keisei to nihon shakai: 'Shisan shoyu minshu shugi' no kikestu (The formation of the corporate-centred society and the Japanese society: a result of the 'property owner's democracy'), in Institute of Social Science, Tokyo University (ed.), Gendai Nihon Shakai, vol. 5, Kouzou (Modern Japanese Society, vol. 5, Structure), Tokyo: Tokyo University Press, pp. 125-67.

Kemeny, J. (1995) From Public Housing to the Social Market: Rental Policy Strategies in Comparative Perspectives, London: Routledge.

Kemeny, J. (2001) Comparative housing and welfare: theorising the relationship, Journal of Housing and the Built Environment, 16: 53-70.

Ministry of Land, Infrastructure and Transport (MLIT), Kouei Jutaku Kanri ni kansuru Kenkyukai (2003) Kouei Jutaku Kanri ni kansuru Kenkyukai Houkokusho (The Report of the Committee of the Management of the Public Housing system), cited from the website of MLIT (see http:/www.mlit.go.jp/kisha/kisha03/07/070911/06.pdf). 
Miyamoto, T., Peng, I. and Uzuhashi, T. (2003) Nihon-gata fukushi kokka no ichi to doutai (Stand and Dynamics of the Japanese Welfare State), appendix to the Japanese trans. of Esping-Andersen (1996), Tokyo: Waseda University Press, pp. 295-336.

Morimoto, N. (2000) Defureka no chintai jutaku sijo (Housing rental market in the age of deflation), Jutaku Kaigi (Housing Council), 58: 17-22.

Nakamura, Keisuke (2005) Koyo sisutemu no keizoku to henka (Continuity and change in the Japanese employment system), in Tokyo University, Institute of Social Science, 2005: 145-73.

Nitta, M. (2003) Henka no nakano Koyo Sisutemu (The Employment System in a Changing Japanese Society), Tokyo: Tokyo University Press.

Noble, G. (2006) Koizumi and neo-liberal economic reform, Social Science Japan, 34 : 6-9.

Ohmoto, K. (1991) Nihon no Jutaku Seisaku (Housing Policy in Japan), Tokyo: NihonHyoron-sha.

Osawa, M. (1994) Bye-bye corporate warriors: the formation of a corporate-centred society and gender-biased social policies in Japan, Annals of the Institute of Social Science, 35: 157-94.

Osawa, M. (2005a) Koizumi's 'robust policy': governance, the Japanese welfare employment regime and comparative gender studies, in Glenn Hook (ed.) Contested Governance in Japan, Sites and Issues, London: RoutledgeCurzon, pp. 1119-29.

Osawa, M. (2005b) Gyaku kinou ni ochiitta nihon gata seikatsu hosho sisutemu (Growing dysfunction of the Japanese style of the social security system), in Tokyo University, Institute of Social Science, 2005: 175-201.

Otake, F. (2005) Nihon no Fubyodo (Inequality in Japan), Tokyo: Nihon Keizai Shinbun Sha.

Sato, I. (1999) Gendai Kokka to Ippan Joukou: Shakuyahou no Hikaku-rekishishakaikagaku-teki Kenkyuu (Modern Welfare State and the General Clause: Comparative Historical Sociology of the Rent Acts in England, Germany and Japan), Tokyo: Shoubun-sha.

Sato, T. (2000) Fubyodo Shakai Nihon (Inequality in Japanese Society), Tokyo: Chuo Koron Shinsha.

Shinkai, Y. (1997) Koukyo seisaku to shiteno shataku seido no bunseki (Analysis of the corporate housing as a public policy), in Y. Fujita and Y. Shionoya (eds) Kigyou-nai Fukushi to Shakai Hosho (Employee Benefits and Social Security), Tokyo: Tokyo University Press, pp. 219-46.

Shinkawa, T. (1993) Nihon-gata Fukushi no Seiji-keizai-gaku (Political Economy of Social Welfare in Japan), Tokyo: San-ichi-shobou.

Shirahase, S. (ed.) (2006) Henka suru Shakai no Fu-byodo (Inequality in Changing Society), Tokyo: Tokyo University Press.

Tachibanaki, T. (1998) Nihon no Keizai Kakusa (Economic Inequality in Japan), Tokyo: Iwanami Shoten.

Tachibanaki, T. (2001) Fukushi ni okeru kigyo no yakuwari (The role of firms in welfare provisions), in T. Tachibanaki and D. Wise (eds), Kigyo Koudou to Roudou Sijou (Corporate Behaviour and Labour Market), Tokyo: Nihon Keizai Shinbunsha, pp. 23147.

Tachibanaki, T. (2005) Kigyou Fukushi no Shuen (The End of the Corporate Benefit), Tokyo: Chuo Koron Shinsha. 


\section{Welfare regime theories}

Tokyo University, Institute of Social Science (2005) 'Ushinawareta 10-nen'wo Koete, vol. 1, Keizai Kiki no Kyokun (Beyond the 'Lost Decade', vol. 1, The Lessons of Economic Crisis), Tokyo: Tokyo University Press.

Tokyo University, Institute of Social Science (2006) 'Ushinawareta 10-nen' wo Koete, vol. 2, Koizumi-Kaikaku heno Jidai (Beyond the 'Lost Decade', vol. 2, The Koizumi Reforms), Tokyo: Tokyo University Press.

Watanabe, O. (1990) 'Yutaka na Shakai' Nihon no Kouzou (The Structure of the 'Wealthy Society' Japan), Tokyo: Junpo-sha.

Watanabe, Y. (1962) Tochi Tatemono no Houritsu Seido (The Legal System of Land and Housing), vol. 2, Tokyo: Tokyo University Press. 


\title{
5 Turning stock into cash flow
}

\section{Strategies using housing assets in an ageing society}

\author{
Misa Izuhara
}

\section{Introduction}

This chapter considers demographic change, addressing ageing of the population in particular, as part of social transition and examines its impact on housing. It challenges the popular debate in many industrial societies including Japan in recent years, concerning the transformation of housing assets into an income stream to help older people provide more financial security in their later life. In Japan this discourse was born largely out of the facts that a significant proportion of financial and material assets were held by older people nationally, and that politicians, policy-makers and economists alike are looking for a means to revitalize the nation's stagnating economy. This chapter seeks to contribute to the debate on an asset-based approach in public policy, drawing upon literature from post-industrial economies, and highlights the impact of the recent shift from family reciprocity to the wider socialization of care on individual asset accumulation. The chapter concludes by exploring the various options and accompanying issues surrounding liquidizing housing assets in old age. The fundamental misconception of such institutional mechanisms is also examined.

The post-war baby-boomers (called dankai no sedai in Japan) are fast approaching their retirement age and some commentators have identified significant implications this may have in the coming decade regarding societal ageing. Partly due to the exceptional size of the cohort (the population born between 1947 and 1950 was 27 per cent and 21 per cent larger than the previous and subsequent cohort, respectively) the baby-boomers have been a key driving force in creating new social trends in the post-war period. In the mid-1970s, for example, when they were in their late 20 s, the 'new family' as opposed to traditional (three-generational, co-resident) families became a focus of discourse. And when they were reaching 'house-buying age' of their 40s, the timing could not have been worse. The baby-boomer households entering the housing ladder, which typically takes place in people's late 30s and early 40s in Japan, coincided with the emergence of the bubble economy in the 1980s. As Hirayama explains 
in chapter 2, the cohort following the baby-boomers was hit the hardest by the 'housing bubble'. The sudden increase in housing demands by the baby-boomer households helped accelerate price increases in urban areas. In fact, between 1984 and 1996, the number of newly built houses was exceptionally high, reaching an average of 1.5 million units per annum, although this trend is now in decline. Now fast approaching their retirement age, is this cohort likely to set another trend in ageing Japanese society? The future of Japanese society is strongly bound up with what will happen to this generation, especially those who are well equipped with financial and housing assets, and my examination will focus on this group within the current social, economic and demographic context.

One of the characteristics of home ownership in Japan is that a plot of land and dwelling are often considered separately, and thus valued separately. 'Housing' is often used as a generic term to describe a dwelling with or without a plot of land in the academic literature. In Japan, however, there is a clear differentiation between land and house (the building on top of the land), especially when we discuss the values of properties. In this context, plots of land hold their value higher and longer than houses due to the short life span of Japanese houses. National climate, materials used and the cultural practice of 'scrap and build' supported by the construction industry are some of the main reasons given for rapid cycle of housing reconstruction and accelerated decline in stock value (see Oizumi, in this volume). In this chapter, the term 'housing assets' implies, as in western home ownership systems, combined assets of land and dwelling, unless specifically stated, in order to make arguments accessible.

\section{Asset-based public policy}

The debate on asset-based approaches in public policy originated in the US and has been transported to many post-industrial economies in the West including the UK, Sweden and Australia. This approach views inequalities in the ownership of assets as problematic and tries to alleviate such inequalities by helping those on low incomes to accumulate assets through policy measures such as individual development account schemes (Regan and Paxton, 2001). Sherraden also emphasizes the importance of assets for low-income individuals and households as 'income only maintains consumption, but assets change the way people interact with the world. With assets, people begin to think for the long term and pursue long-term goals. In other words, while income feeds people's stomachs, assets change their minds' (1991: 13). In his more recent work, Sherraden (2003) points out changes in welfare policy in some developed economies as a shift away from a welfare state to a social investment state, where the overarching role of government is to build up people's capacity. In the UK, where an asset-based approach is relatively new, the neoliberal approach of selling council housing since the $1980 \mathrm{~s}$ can be interpreted as asset-based welfare assistance for low-income households 


\section{Misa Izuhara}

through supported entry into the home ownership sector. More recent initiatives include the Saving Gateway and the Child Trust Fund, which are designed to strengthen financial education and to promote positive attitudes towards saving among low-income households. The latter is aimed at providing young people with more equal conditions (despite their family wealth) at the start of their adult lives through a stock of financial assets. In relation to housing, a proposal on an equity share scheme (the idea of granting social-renting tenants part ownership in terms of the value of their homes) has been identified as a means to assist lowincome household saving (Chapman and Sinclair, 2003).

The important role that assets play in contemporary society is to allow individuals or households access security, independence and opportunities on top of the mere ownership of financial and material assets. In other words, the lack of access to asset accumulation not only hinders the development of financial and physical (housing) capital but also precludes people from building human and social capital (Latham, 2001). Such interconnectedness of different types of assets is illustrated in the rationale behind developing Individual Development Accounts:

... an individual could save into an account (thereby accumulating financial capital), then invest in education (building human capital) or buy a home (accessing physical capital), whilst taking part in financial training (again building human capital) and being supported by and connecting with a community-based organisation (contribution to social capital).

(Regan and Paxton, 2001: 3)

In many capitalist societies, accumulation of individual assets occurs largely through institutionalized mechanisms, primarily via home ownership and pension schemes that are clearly defined and heavily subsidized within public policy (Regan and Paxton, 2001). Therefore, as Paxton (2003) puts it, asset-building policies were primarily geared towards the affluent: what was described as the fiscal welfare state by Titmuss (1958). Throughout the post-war economic growth period, the Japanese government encouraged the majority of households to become homeowners and thus to accumulate their own housing wealth through heavily subsidized, low-interest loans from the Government Housing Loan Corporation. Such self-reliance in accessing quality housing was also made possible through the unique system of occupational welfare - the 'productivist' notion of the welfare state linking welfare provision with the labour market performance and individual employment status (Holliday, 2000). As many welfare state analysts point out, however, the system has inevitably created social inequalities between households according to their position in the labour market. Under the system, access to home ownership has been restricted for low-income households, those in unstable or irregular employment, and single and female-headed households. 
In addition, traditionally, welfare policy tends to have anti-asset elements signified in means-testing. Means-tested public assistance is a form of institutional disincentive for individuals to accumulate assets through the setting of an 'asset limit'. For example, it is very difficult for Japanese owner-occupiers (especially with mortgages) to access public assistance once they lose regular income or experience a substantial salary cut, which are increasingly likely under the current shift towards more flexible employment practices in Japan's troubled economy. Public assistance is not designed to cover mortgage repayments (Seikatsu Hogo Hoki Kenkyukai, 2003), and this can be understood to signify the policy stance that public money is not for investing in individual asset accumulation.

In terms of ageing societies, the different ways in which states perceive and treat individual asset accumulation regarding long-term care are indeed, manifest in fundamental differences across societies (Izuhara, 2005). For example, who is responsible for the cost of long-term care is a well-debated issue in many industrial societies. In England, for example, the necessity to sell a home - accumulated asset - in order to move into residential or nursing homes has been the source of public outcry (Askham et al., 1999; Royal Commission on Long Term Care, 1999). In this scenario, policy-makers consider the housing assets of individuals as a source of income in old age. Moreover, people with capital or savings of more than $£ 18,500$ are expected to meet the full cost of their long-term care fees. Japan, on the other hand, has recently taken an alternative strategy to funding increasing care needs in an ageing society. Under the new social insurance scheme (Koteki Kaigo Hoken) introduced in 2000, both personal and nursing care provision is no longer means-tested, and thus everyone has an entitlement to receive long-term care according to criteria of the extent of physical and mental disability. This system allows individuals (and their families) to retain their wealth, including residential property, while receiving public services under the scheme. I will return to discuss this in detail later in the chapter.

The rationale behind recent developments in asset-based approaches in public policy is to help achieve a more equal and inclusive society, giving the opportunity to those on low incomes to accumulate assets. The approaches in the West thus specifically target low-income households to assist their entry into a pathway of asset accumulation. In addition, many other existing, mainstream policies, such as the promotion of home ownership and state-assisted pension schemes, can also be interpreted as asset-based welfare. Nevertheless, such neoliberal approaches have exacerbated social inequality. While the intergenerational transfer of assets has played a part in widening the wealth gap between haves and have-nots, the later stage as well as the starting point of asset accumulation in people's life-course is also critical and requires scrutiny. 


\section{Assets, housing market and demography}

\section{'Asset-rich, cash-poor': the financial status of older people}

The total wealth of households is made up with their income and assets. Income includes earnings from both economic activity and other sources such as rent from properties and profits from investments, while assets can be categorized as financial assets (e.g. savings and investments) and material assets (e.g. ownership of real estate, automobiles and, in Japan's case, membership of a golf club!). Overall assets of individuals or households also consist of the sum of both positive and negative assets (debts).

The tendency is to regard older people as being 'asset-rich, income-poor', reflecting their labour market status as 'retired'. When people reach their retirement age, they tend to rely on a limited income (i.e. pensions), which reinforces the social construction of old age. According to the Ministry of Health, Welfare and Labour in 2000, for example, the average income of older households was made up of 62 per cent of pensions, alongside 28 per cent earned from economic activity. The income of older people has in fact grown over the post-war period, keeping pace with the general growth of that of the working population, thanks to the increased benefit of pension insurance (which is closely linked to people's labour market performance in Japan). Compared with general households, however, the income of older households tends to be much more concentrated in the bottom few income bands. In 2000, some 13 per cent of older households received annual income below 1 million yen $(£ 5,000$; $¥ 200=£ 1)$ and another 30 per cent received that of $¥ 1-2$ million ( $£ 5,000-£ 10,000$ ).

The pattern of ownership of assets, however, paints a different picture of old age. The amounts of assets households have increases as people age, reflecting the characteristics of Japanese saving patterns (Table 5.1; Figure 5.1). Despite the real, if sometimes romanticized inter-generational family values in Japan, the 'life-cycle model' as opposed to the 'dynasty' and 'altruism' model dominates household saving behaviour, in which people save primarily for retirement and other events in their own life-course (Horioka et al., 2000). The majority do not save simply to pass assets on to the future generations or strategically to exchange for family support. It is puzzling, however, that many people continue to save well into their old age, instead of eating away their savings after retirement.

According to the Survey conducted by the Ministry of Post and Telecommunication on household economy in 1996, a significantly high proportion of those in their 60 s (64 per cent) and 70 s and over (58.9 per cent) were still saving for their own old age, while the younger generations (over 50 per cent of those who were in their 30s and 40s) were more likely to be saving for their children's education. It is surprising to find that, despite the notorious ' 0 per cent interest' in the Japanese banking sector and stagnated income growth in the post-bubble economy, household savings grew while the value of real estate assets has fallen. 
Table 5.1 Estimated value of assets per household by age group of household head (in thousand yen)

\begin{tabular}{lccccccc}
\hline & Average & $<30$ & $30-39$ & $40-49$ & $50-59$ & $60-69$ & $>70$ \\
\hline $\begin{array}{l}\text { Total } \\
\text { assets }\end{array}$ & 38,689 & 6,600 & 17,778 & 31,872 & 44,954 & 57,160 & 59,937 \\
$\begin{array}{l}\text { Financial } \\
\text { assets }\end{array}$ & 8,727 & 946 & 283 & 3,114 & 10,112 & 17,869 & 17,105 \\
$\begin{array}{l}\text { savings- } \\
\text { debts) }\end{array}$ & & & & & & & \\
$\begin{array}{l}\text { Real } \\
\text { estate }\end{array}$ & 28,346 & 4,633 & 15,911 & 26,917 & 32,858 & 37,569 & 41,809 \\
\hline
\end{tabular}

Source: National Survey on Consumption 1999.

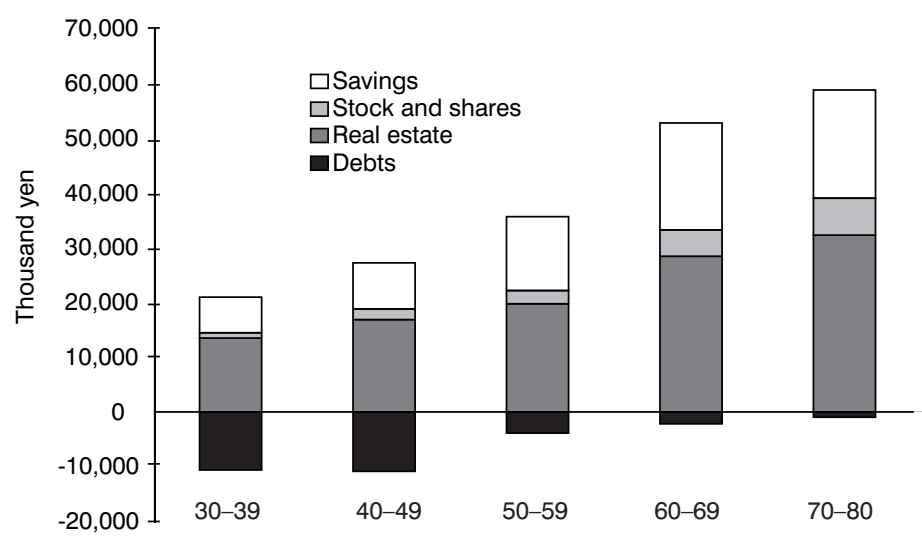

\subsection{Value of assets per household by age group of household}

Source: Arakawa, 2003b.

Note: Survey conducted by the Daiichi Life Insurance Research Centre in 2002 among 918 samples aged between 30 and 80 .

At the turn of the century, however, the impact of the prolonged recession has started being more visible, with increased rates of households without savings. Economic uncertainty and precarious employment conditions are the factors contributing to such household behaviour.

While the aggregated data conceals the level of wealth inequalities within old age, the cohort of older people appears to hold more than a half of the nation's financial assets. According to the 2000 survey on attitudes towards savings, 53 per cent of financial assets, and 69 per cent if debts are excluded, were owned by those aged 60 and over. This is also the case when we look at housing assets. Older households are indeed more likely to own greater (un-mortgaged) housing equity, 
reflecting the timing of house purchase and duration of owner-occupation (Figure 5.1). The rate of home ownership is as high as 80 per cent among those aged 60 years and over. Furthermore, approximately 20 per cent of real-estate assets of older people were properties other than their owner-occupied housing.

Finally, the fact that the nation's wealth is largely held by the older generation has now provoked a debate on 'making older people spend their fortunes' as part of revitalizing the nation's stagnated economy and also to help tackle swelling welfare expenditure. Indeed, the high level of financial and housing assets means that considerable numbers of people own accumulated assets which could be turned into income streams. The difficulty in realizing this proposal is, however, that assets are largely tied into owner-occupied housing, which, unlike savings, is difficult to liquidize.

\section{Volatility in the housing market}

It had been a common belief that, partly due to the lack of land in urban areas, housing prices would consistently rise and home ownership was inescapably accompanied by capital gains - that is, until the economic bubble burst in the early 1990s. Under earlier circumstances, people aspired to become homeowners and expected to accumulate assets through housing price inflation. This discourse is now in crisis, as the housing market has remained depressed for some 15 years.

The prolonged recession eroded people's confidence and their ability to invest in housing, which is particularly evident among the younger generations. Entry to home ownership has been delayed over the last two decades. The home ownership rates of the age groups 25-9 and 30-4 declined from 25 per cent and 46 per cent in 1983,13 per cent and 32 per cent in 1993, to 8 per cent and 21 per cent in 2003, respectively. Some scholars may argue that deliberate delaying of entry is driven by the expectation of the younger generations of inheriting parents' property, but there is no clear evidence to support the argument. In comparison with the steady growth of financial assets, poor performance of real-estate assets has been evident in recent years. According to the National Consumption Survey in 1999, the total wealth of average household has declined 18.4 per cent compared with the 1994 data, with the devaluation of real-estate assets as the major contributing factor. Land and housing assets fell 26.4 per cent and 5.9 per cent respectively, while the level of financial assets rose 5.7 per cent in the five-year period.

An over-supply of housing may have also contributed to housing price deflation. The contemporary pattern of urban (housing) developments being, in nature, high density, together with the predictable decline of the number of households in a low fertility society, has meant that housing shortages have become a thing of the past. In a similar vein, the White Paper on Land in 2004 anticipated the negative impact that a growing number of vacant houses would have on many neighbourhoods - for example, fear of crime and anti-social behaviour. 
The expected life-span of Japanese houses being 'culturally' short is highly problematic if housing is considered as a tradable commodity later in people's life-course. A single-family home, if the purchasers were in their 40 s, would require substantial renovation or even total rebuilding later in their life-course. The owners of condominiums, an increasingly popular and common option for urban households, will also face substantial related problems because of their lack of durability and their even more dramatic price deflation. The condition and values of housing are of primary importance when older people try to utilize their housing assets to raise funds in old age.

\section{The impact of demographic change}

Low fertility is one of the key driving forces leading to societal ageing, and its causes and consequences are well debated in contemporary Japan (see e.g. Kawamoto, 2001). The fertility rate dropped to a record low of 1.29 in 2004. The factors influencing this demographic change are multifaceted and include both the social and economic. Most notable are women's increased social participation and declining willingness to start a family due to associated opportunity costs; people delaying marriage or not marrying at all (babies born to unmarried mothers are still uncommon in Japan); and even married couples being less confident in having a second and subsequent children or delaying having them due to the prolonged recession and accompanying precariousness in employment (Iwasawa, 2001; Ogawa, 2001).

The Japanese pattern of fertility is unlike that of Italy, where many couples tend to have one child only (Bettoni, 2006). If we look at the fertility rate among Japanese 'married' couples, it has been stable at around 2.2 (enough to maintain the nation's population) for the last three decades (Iwasawa, 2001). This suggests that some families are having two or three children, while an increasing number are having none.

What is significant for understanding social changes in Japan is that individuals and couples are increasingly choosing not to have children, which affects their asset accumulation and disposal where there may be diminished incentives to accumulate and protect assets for future generations. Under current economic conditions, those without children may opt for rental accommodation, given the likely financial burden of a long-term mortgage. And in the case of owneroccupiers, housing assets may be viewed as more disposable with fewer and fewer households looking to trans-generational accumulation and more and more households having greater incentive to use their assets more effectively in old age.

Increased longevity, the other side of the same coin of societal ageing, tends to delay intergenerational asset transfer, which also has significant implications for asset accumulation and disposal. Increased longevity means two or more 
adult generations are likely to exist as separate households for longer. Unless older people strategically transfer assets early to help younger generations, adult children are likely to have an established household with an (un-mortgaged) owneroccupied house by the time they inherit. Inheritance skipping a generation is one predictable outcome. However, given the accidental nature of bequests under the life-cycle model, wealth tends to flow from the old-olds to the young-olds and thus remains stubbornly in the older age group and subsequently under-used (or unused) (Arakawa, 2003a). Inheritance received later in people's life-course has little impact on their consumption or investment patterns. A survey conducted by the Daiichi Life Insurance Research Centre in 2002 confirmed that for 81.4 per cent of those who had inherited assets, there was no significant effect in their consumption and investment pattern after inheritance (Arakawa, 2003b). Arakawa (2003a) therefore suggests that breaking the cycle of such unused or under-used assets among older people, by encouraging them to spend more or transfer wealth earlier to younger generations, can be one way of stimulating the economy.

Despite the cultural understanding of housing as 'family assets', which were accumulated and passed on over the generations, housing has been increasingly 'commodified' in Japan (Izuhara, 2005). The decline of co-residency suggests that the clear line and obligation of household succession within the family are also diminishing. Do all the above factors work to the advantage of older people in turning their housing stock into a cash flow?

\section{From family reciprocity to socialization of care: the paradox of institutional mechanisms and wealth accumulation}

Family obligations and asset transfer have in the past been explicitly connected in the Japanese social and legal systems. Until the traditional form of the ie (family) system was abolished by constitutional reform immediately after the Second World War, eldest-son succession was the norm, reflecting the patrilineal stemfamily system (see Ronald, in this volume). The successor child looked after his parents through co-residency and, in return, inherited the family wealth intact (although practical care was often provided by the daughter-in-law). Co-residency certainly provided a perfect structural context for such an exchange to take place. In a society where the family had the central responsibility to care for their older members, and where high rates of home ownership exist, this exchange has continued to thrive until recently (Izuhara, 2002).

Japanese society has recently witnessed gradual changes in family structure and function, however, and the link between care provision and inheritance has been increasingly divorced through, in part, independent living that has gained in popularity among older people (Izuhara, 2005). The introduction of a new social insurance scheme for long-term care in 2000 was indeed one of the major 
turning points for shifting care responsibility from the family to the state. Whether such socialization of care would further accelerate family disengagement from traditional duties is another debate, but the rationale behind it not only reflected demographic changes and economic downturn, but also that the family was on the verge of collapsing under the heavy burden of care (particularly for women), and the declining capacity of the family to care, partly due to the increased geographic distances between the generations and increased female labour market participation (Peng, 2002).

This section examines a paradox in the new institutional mechanism on social care delivery. Unlike the means-tested approach applied in many western industrialized societies, Japan has opted for a social insurance approach. The system of funding care and the criteria for service provision are both distinctive features of the social contract between individuals and the state. Social insurance differs from tax-based systems in terms of the mechanism of funding, its coverage, eligibility and entitlement (Ikegami and Campbell, 2002). What are relevant here are the eligibility criteria. One of the advantages of social insurance rests on making long-term care an explicit and uniform entitlement for everyone, with eligibility decided according to 'objective based criteria on the extent of physical and mental disability' (Ikegami and Campbell, 2002). Other individual conditions such as income, assets and the availability of family care are irrelevant in the assessment process in Japan. In other words, as long as people pay a monthly premium (which is deducted from their pensions), they can receive services with 10 per cent co-payment once the need arises. It is inevitable that this scheme creates social inequality among older households (Izuhara, 2003). The winners are primarily the middle to higher income households who used to meet the full cost of care entirely from their own pocket and who can now access public services while retaining their assets. On the other hand, low-income households lose out because of the double burden of compulsory contribution and user fees. Many have to keep contributing to the funds without any prospect of using services due to the affordability issue over co-payment.

The separation between care provision and asset transfer is evident here, and the current system encourages the further accumulation of trans-generational wealth. Some scholars therefore argue that, as inheritance has been traditionally viewed as a reward for caring for older members within the family, the current system presents a distortion of such a generational contract. Long-term care has now been 'socialized' in order to maintain or strengthen the social security system, which the better-off with assets are currently benefiting most from. A debate has emerged concerning the means to reimburse society from individual assets, instead of protecting assets for children (Atusmi, 2001). The need to shift the boundary of the micro-level 'generational contract' regarding care and inheritance to a macrolevel social contract has become an increasingly salient argument in discussions of welfare in Japan. 
If the provision of social care is not means-tested, Atsumi (2001) argues that inheritance tax may help redistribute individual wealth back to society. Under the current inheritance tax system, only 10 per cent of those aged 45 and older were subject to taxation after their death. Despite the nine-stage progressive taxation, which taxes higher asset owners much more, the bottom line of eligibility is set very high ( $¥ 90$ million (£450,000) for the family of a spouse and two children), leaving only 10 per cent of asset transfers currently taxable (Ministry of Finance, 2001).

If the primary motivation for saving behaviour had been a response to potential health and financial risks in old age, the Long Term Care Insurance has reduced the individual risk by shouldering a potentially large burden of care costs. A survey conducted by the Ministry of Post and Telecommunication in 2004 revealed that the reason people were decreasingly intending to leave an inheritance for children was not because 'they wanted to spend their assets themselves' (14 per cent) but that 'they did not feel they could afford to do so' ( 80 per cent). Nevertheless if people still continue to save, such cultural behaviour may come from people's varying perception on risks (Tachibanaki, 2004). Parsons points out the complexity of defining problems in the application of policies or solutions since 'values, beliefs, ideologies, interests and bias all shape perceptions of reality. Problems involve perceptions and perceptions involve constructions' (1995: 88). He goes on to explain that, 'although problems are ill-structured, government is highly structured and this means that all problems have an organisational or governmental context which has a major influence on the way in which problems come to be structured' (p. 89). Since institutions are major players in problem definition and policy-making processes, public policy may also be able to manipulate people's perceptions, and influence their attitudes towards asset accumulation and consumption. In this context, potential strategies for transforming or liquidizing the assets of older people depend on whether it is possible to change people's perceptions of risk.

\section{From housing stock to cash flow}

Policy-makers and some academic commentators increasingly view turning existing assets of individuals into an income stream as a necessary strategy in the revitalization of the nation's economy. This is also debated in the context of current recession, labour market restructuring, and demographic change, which combine to produce uncertainty in future pension funds and return from investments. To secure and supplement their income and to meet the changing needs of housing in old age, there are indeed various options that older people could deploy to release part or all of their equity tied to housing. This section explores the pros and cons of such options, focusing largely on the experiences of older homeowners. 


\section{Reverse mortgages}

There are various ways to utilize housing assets to generate income for old age. For 'asset-rich, income-poor' homeowners, reverse mortgage schemes are, in theory, very attractive options for those who have limited income and would like to release some of their equity tied to an owner-occupied house while remaining independent in their own home. This is particularly a good option for people who are reluctant to move in old age for various social and financial reasons. It also meets a recent policy emphasis, not only in Japan but also in many developed economies, upon older people 'staying put' or 'ageing in place'. Although often driven by financial concerns relating to the cost of institutionalization, this policy logic has also been supported by the aspirations and preferences of older people themselves for independence and autonomy. This policy focus of shifting away from social hospitalization to supporting people in need in their own home was central to the development of new social insurance for long-term care in Japan.

Reverse mortgage schemes are currently operated by both private financial institutions and local authorities (most in association with financial institutions) in Japan, but the take-up rates are still insignificant. For example, there were only 18 users in 1998 in Musashino City, Tokyo, the pioneer local authority with the longest established scheme in operation since 1981. Like Britain, the evident failure of such schemes to attract many older homeowners, however, suggest that there are various barriers to take-up and a degree of resistance to their use (Okuda, 1999; Davey, 1996; Joseph Rowntree Foundation, 1998). The increasing volatility and uncertainty of housing and financial markets is one factor. Homeowners and financial institutions alike may be less confident about future property values and the rise of interest rates than before. Many restrictions therefore apply to older homeowners, such as low borrowing limits and, for most, purpose-specific monthly payment limits apply. For example, given the likely devaluation of property, 70 per cent of the market values is often available for owners of single-family homes, but the available rate drops to a maximum of 50 per cent for condominium owners. Some institutions even exclude condominium owners from applying for the schemes. Prolonged longevity and accompanying uncertainty in how long people are going to live also add further complications to setting a loan period. Some people may exhaust their funds long before they pass away but it has proven difficult for local authorities and financial institutions to force older homeowners to repay, which defeats the initial purpose of the mortgage. Older people may also lack adequate information or reliable advice to take up this option.

In addition, it is likely that cultural values and pride still play a significant role. As UK research found, older people 'do not want to be in debt' or 'do want to pass something to the next generation' (Davey, 1996). In the case of Musashino City, the majority of remortgagers do not have children. At their death, their beneficiaries are more likely to pay off the mortgage debts from their own savings or loans, rather than by raising funds from the sale of the inherited property. The continued 
importance of Japanese cultural practices of family wealth accumulation and inter-generational asset transfer is indicated by the fact that a guarantor, often an adult child, is a prerequisite for an older homeowner in joining a scheme. Such institutional constraints help families to maintain the customary generational contract, and thus to protect housing assets for the future generations.

\section{Renting out additional properties}

The recent deregulation of the Leasehold Act opened doors to this option for nonprofessional property owners and investors. Short-term leasehold gives property owners the right to refuse an extension of a contract without any reason. Under the previous regime, many individual, non-professional owners were reluctant to let their houses due to the risk and uncertainty of tenants occupying their house for an unspecified period of time. It is believed among a specific group of neoliberal scholars and businesses that such deregulation will encourage an expansion of rental stocks (especially, large-size housing), decrease rents and ease the existing burden on property owners who make up the shortfall of public sector rental (Abe et al., 1997; Hatta, 1998). It may also stimulate the economy through urban redevelopment. However, the social needs and protection of tenants are largely ignored in this shift. Stability in the rental sector has been inevitably reduced, and the cost of such a shift tends to fall on low-income tenants - many of whom are elderly.

As a consequence, an increasing number of people who have additional properties besides their owner-occupied house are renting out their spare housing, many of them to their relatives. The proportion of those who own additional properties is higher among elderly households (see also Hirayama, in this volume). This is indeed one way of boosting their income in old age although the option is only available for a fortunate few who have invested in or inherited properties in the past. Increased inheritance prospects in a low fertility society may expand the beneficiaries of this option but the location, age and type of housing stock will dictate the rentability and thus the level of rents achieved.

If inheriting and letting out property is a passive route into landlordism, a more proactive route can be facilitated by purchasing a buy-to-let property to supplement income in old age (following the popular discourse in the UK) or as a component of longer term investment planning. Whether this works so well in Japan is, however, questionable. The modest revival in the private rented sector in the UK has been accompanied by a sharp increase in the number and proportion of individual landlords backed by deregulation, the greater availability of mortgages and, in some cases, by the effect of negative equity (Heron and Stevens, 1999). Those non-professional investors were attracted partly by strong capital gains in the past, but the future of the market will depend primarily on the 
demand for private rented property which is supported by demographic factors, changing labour and lifestyle patterns, as well as government policy (Pannell and Heron, 2001). As the number of vacant properties is already becoming an issue in contemporary Japan, winners and losers may be divided by how their additional properties meet the demands of the changing rental market.

\section{Trading down}

Trading down involves both inter- and intra-tenure downward movements in terms of size and value of property. Older people can move to purchase a smaller, more manageable and less expensive property (e.g. a small condominium unit instead of two-storey, single-family home) to release some equity from current housing. The benefits of trading down are not only releasing some of the equity tied into a large owner-occupied house but also achieving greater manageability in terms of living space and environment while retaining independent living. Compared with some western societies where moving houses according to people's life-cycle need is more popular, the Japanese tend not to move once they acquire a singlefamily home. The housing market, however, highly dictates the destinations of older movers.

An inter-tenure movement from owner-occupation to tenancy can be attractive for some who view owning a house in old age as a liability in terms of maintenance and property tax. Given the fact that 80 per cent of older households are owner-occupiers and that the average size (floor space) of an owner-occupied house is almost three times larger than rented accommodation (Management and Coordination Agency, 1998), the potential impact of liquidizing housing assets of older people upon the rental market would be significant. By trading down, the current likely mismatch of household size and their living space, considering different stages of the life-course, could be rectified. A large demand by younger families with growing children for good-quality, larger size housing in the private rented sector could be met by properties strategically released by older homeowners who are likely to be empty nesters. The Ministry of Land, Infrastructure and Transport views such redistribution of housing stock as a vital and effective way of meeting the needs of households in different stages in their life-course, and is promoting new initiatives such as the establishment of support centres for movers and a sub-lease insurance system (Gekkan Fudosan Ryutsu (July 2003), 84-6).

Moreover, trading down could be the only means for older people who are willing to move from a depressed housing area to a popular, up-coming urban area. For example, the only way for older parents who want to relocate closer to their only child in the Tokyo metropolitan area may be by selling their 40-yearold detached house in a suburb of a small city and to rent a unit in the public or private rented sector. It is inevitable, however, that the capital from the sale of the 
property will be gradually eaten away, which may threaten children's inheritance. Condominium owners who face the necessity of redevelopment (due to the short life-span of residential buildings) in their old age may, although reluctantly, need to take up this option, given their limited income and considerably reduced housing equity. The future of shared ownership in condominiums poses many questions, especially since the passing of the new Act - when the cost of demolition is subtracted from an already small share of individual equity from a plot of land, it is almost impossible to buy back a unit in a newly built building on the same site.

Furthermore, if people rely on the 'risk-averse' rented housing market, problems begin to appear when they reach a certain age. Age discrimination largely exists in the private rented sector, thus entry into private renting in old age appears almost impossible in Japan. Becoming a tenant or trying to look for alternative rented accommodation in old age poses a great challenge, especially for lone (female) tenants, due to limited public provision, costly alternatives in the market and discrimination against older tenants who may be viewed as a potential problem (e.g. causing fires, dying in the property) by landlords and estate agents (Izuhara, 2000). Approximately 40 per cent of private management agencies refuse older tenants access to the majority of their rented accommodation. This fact makes older homeowners cautious in considering the option. There is however an increasing recognition that the effective use of both existing housing stock and private market initiatives is the key to promoting good-quality housing for older people in an ageing society. Tackling the issue regarding the refusal of older tenants by landlords and managing agencies was one of the aims of the new Act (ensuring housing stability among older people) in 2001. Under the Act, the proposal was to set up a voluntary registration scheme for landlords and managing agencies that are willing to take in elderly-headed households and strengthen the communication channels to spread information regarding elderly-friendly landlords. Some public funds attached to this initiative (in the form of rent guarantees) provide landlords and management agencies with an incentive to achieve a more inclusive, un-agebiased private rented sector.

\section{Moving to purpose-built housing for older people}

The move into supported housing has only been an option for a minority in Japan, reflecting the under-development of the housing sector and the current condition of the housing in the private market. In response to new and growing demands for independent living by older people, there have been both publicly funded and privately developed supportive housing projects operating in Japan since the late 1970s. Private housing complexes offer a wide range of independent services for their residents, including a dining room for group meals in addition to individual kitchenettes, a communal bath, an emergency alarm system, 24-hour 
front services, communal facilities such as lounges, library and activity space, and organized social clubs and activities. Indeed, supportive housing assists older people in maintaining a (semi)-independent lifestyle and prevents unnecessary institutionalization as they grow older. Linking housing with social services has now become an issue in Japanese housing policy and practice for older people. This type of housing is therefore a practical solution when independent living or living with other (extended) family members is undesirable or impossible for physical, emotional or financial reasons. However, this costly option has lower priority within the limited resources of many local authorities, especially under the more recent policy emphasis on home care.

The private projects serve only relatively affluent older people since they usually require an initial large lump sum to purchase the 'life-estate', and a monthly fee for management and operation. Life-estate is the right to occupy a property for the period of one's natural life, which reverts to the project owner thereafter. In this scenario, the released housing equity from the sale of their current housing would be immediately put back into the housing sector (unless one holds sufficient savings to cover the cost). This option is attractive for some elderly owners because: 1) purchasing a life-estate is often cheaper than purchasing the similar unit with full ownership; 2) a life-estate is not subject to property tax and maintenance (as long as they pay monthly fees); and 3) there is no threat of eviction unless ill health requires hospitalization. Such places also attract those without children and thus without family obligations or any expectation of inter-generational asset transfer. However, research has also found a number of cases where those who had children have made a positive decision to move into such housing (Izuhara, 2005). In those cases, the decision to break the generational contract involving inter-generational transfer came from either the constraint of cultural practices or liberation from them. This also highlights a strong gender dimension in family support structure. In one case, a widow, who moved to live in private housing for older people, did not think it mattered whether she had kept the house or not since her children were all married with their own houses and had no intention of coming back to live with their widowed mother. In another case of an older female resident, her daughter was married to an only son whose mother was also widowed. In her view, it was right if his mother lived with them following the traditional patrilineal succession system. It was, however, not logical for her to expect to live with the young family. Since she had married off her only daughter, the matrilineal mother knew she would be on her own when her husband died. In any case, 'children being well established' was often a condition for older people disposing of their assets early to move into such purpose-built housing. 


\section{Inter-vivo transfer}

If the timing of inheritance matters, transferring assets early to the next generation helps the stagnated entry of younger people into the home ownership sector significantly and thus may boost the nation's (housing) economy. This strategy can be combined with other options mentioned above but does not necessarily directly benefit older homeowners themselves. Additional allowances for house purchase and improvements are more generous in Japan, reflecting the current government's intention to stimulate the economy by providing families with an incentive to redistribute rather than save their assets. In 2003, tax-free cash allowances were raised from 1.1 million yen $(£ 5,500)$ per annum to a total allowance of 25 million yen $(£ 125,000)$. The private sector has also been promoting a new type of extended family living. The Japanese housing industry markets a considerable amount of 'Two-household housing', which is detached housing, planned on the presumption that older parents co-reside with their adult children, and is often built on land owned by the older generation. One of the major reasons for decreasing rates of co-residency has been the drawback of such living arrangements. The close physical proximity of different generations, each with their own needs, desires, lifestyles and preferences, has often led to conflict within the extended family. This problem has been reduced with the new design allowing for the creation of two separate households, with separate amenities and facilities, all under one roof. This type of housing is often achieved using a cooperative investment by elderly parents and their adult children - a loan inheritance scheme over generations forming one type of inter-vivo transfer.

Looking at the saving behaviour of older people, the life-cycle model suggests that the majority (for example, 70 per cent of the respondents of the survey conducted by the Daiichi Insurance Research Centre) are not living by 'scrape and save' for future generations but are planning only to leave funds if anything is left at the end of their own lives. This implies that older people have limited capacity for making inter-vivo transfer or are not willing to do so anyway. According to the same survey, older people tend to view 'financial support for children to obtain their housing' as not part of inheritance but part of their parental obligation of bringing up children. However, only a limited group of older people in fact help their offspring with house purchases in any significant way. This may therefore not be the most effective way to turn assets into a cash flow.

\section{Conclusion}

This chapter has identified that a large proportion of the nation's wealth is held by older people, and, despite the transfer of assets over the generations, wealth tends to remain in the owner-occupied properties of this particular age group due to increased longevity as well as people's perception of risk in Japan's troubled 
economy. The chapter also highlighted a paradox of the welfare state mechanism in relation to the new social insurance on long-term care, which has shifted the responsibility of care away from the family to society, while family wealth (which used to be considered as a reward for care giving) remains within the family. Protecting assets of older people may require, however, the protection of assets for future generations, which in a way works against the principle of the assetbased approach. The current system indeed encourages trans-generational asset accumulation rather than alleviating social inequality among households by redistribution of household wealth.

Various options for turning housing assets into cash flow were presented in terms of both pros and cons of each approach. The low take-up rate, however, suggests the government's intention of liquidizing older people's assets has been slow to materialize under the current housing and financial regime. One important factor is the recognition of people's preference for 'ageing in place', which is also supported by the current policy priority of promoting home care. The reluctance of older people to take up some of the options is because their assets are largely tied to their owner-occupied homes. The negative impact of a move often outweighs the benefits for older homeowners. Displacement from the familiar neighbourhood, the cost of moving and insecurity and affordability issues in the rental sector are some of the reasons. Despite the importance of inheritance and cultural bound meanings of family wealth accumulation, they do not appear to be the primary obstacle to the disposing of housing assets in old age. This suggests the uniqueness of inter-generational exchange and family obligations have been gradually diminished in Japan.

\section{Acknowledgements}

This article forms part of the output from research funded by the Economic and Social Research Council (ESRC) UK (Grant no. RES000220798) on 'Care and inheritance in Britain and Japan: the younger generation's perspectives'.

\section{References}

Abe, M. (2004) Sozoku no katei ni miru oya no senryaku-teki na zaisan kanri (Strategic property management of parents seen in the process of inheritance), Sociologos, 28: 202-15.

Abe, Y., Iwata, K., Segawa, N., Nomura, T. and Yoshida, K. (1997) Teiki shakuya-ken ron wo megutte (The debate on periodical tenancy rights), Jurist, 1124: 4-40.

Arakawa, T. (2003a) Koreisha hoyu shisan no genjo to sozoku (Older people's assets and inheritance), Life Design Report, 2003(5): 16-23.

Arakawa, T. (2003b) Koreisha shisan no ryudo-ka (Liquidising assets among older people), Life Design Report, 2003(9): 4-15. 


\section{Misa Izuhara}

Askham, J., Nelson, H., Tinker, A. and Hancock, R. (1999) Older owner-occupiers' perceptions of home ownership, Joseph Rowntree Foundation <www.jrf.org.uk/ knowledge/responses/docs/residentialaccommodation.htm>.

Atsumi, N. (2001) Shakai hosho zaigen toshiteno sozoku shisan no katsuyo (Utilization of inheritance assets as social security resources), Fuji Research Institute Corporation Study Report, Dec.

Bettoni, F. (2006) Strong in tradition and yet innovative: the puzzles of the Italian family, in M. Rebick and A. Takenaka (eds) The Changing Japanese Family, London: Routledge.

Chapman, M. and Sinclair, S. (2003) Equity Shares in Social Housing, London: ODPM.

Davey, J. (1996) Equity release for older home owners, Joseph Rowntree Foundation $<$ www.jrf.org.uk/knowledge/findings/housing/h188.htm>.

Hatta, T. (1998) Teiki-shakuchi-ken ha Nihon no Jutaku Jijo wo gun to yokusuru (Shortterm leasehold will improve housing situations in Japan), The Economist (Japan, 28 April), 71-4.

Heron, J. and Stevens, S. (1999) From deregulation to buy-to-let: developments in the private rented sector, Housing Finance, 48, London: CML.

Hirayama, Y. (2003) Housing policy and social inequality in Japan, in M. Izuhara (ed.) Comparing Social Policies: Exploring New Perspectives in Britain and Japan, Bristol: Policy Press, pp. 151-72.

Holliday, I. (2000) Productivist welfare capitalism: social policy in East Asia, Political Studies, 48(4): 706-23.

Horioka, C.Y., Fujisaki, H., Watanabe, W. and Kouno, T. (2000) Are Americans more altruistic than the Japanese? A US-Japan comparison of saving and bequest motives, International Economic Journal, 14(1): 1-31.

Ikegami, N and Campbell, J.C. (2002) Choices, policy logics and problems in the design of long-term care systems, Social Policy and Administration, 36(7): 719-34.

Iwasawa, M. (2001) Kekkon shinai koibito tachi (Couples not willing to marry), in S. Kawamoto (ed.) Ronso Shoshika Nihon (Debate: Low Fertility Japan), Tokyo: Chuo Koron Sha, pp. 51-69.

Izuhara, M. (2000) Family Change and Housing in Post-War Japanese Society: The Experiences of Older Women, Aldershot: Ashgate.

Izuhara, M. (2002) Care and inheritance: Japanese and English perspectives on the 'generational contract', Ageing and Society, 22(1): 61-78.

Izuhara, M. (2003) Social inequality under a new social contract: long-term care in Japan, Social Policy and Administration, 37(4): 395-410.

Izuhara, M. (2005) Residential property, cultural practices and the 'generational contract' in England and Japan, International Journal of Urban and Regional Research, 29(2): $327-40$.

Joseph Rowntree Foundation (1998) Failure: equity release, findings <www. Jrf.org.uk/ knowledge/findings/housing/hrd58.asp>.

Kawamoto, S. (ed.) (2001) Ronso Shoshika Nihon (Debate: Low Fertility Japan), Tokyo: Chuo Koron Sha.

Latham, M. (2001) Stakeholder welfare: an asset-based approach to Australian welfare, in S. Regan and W. Paxton, Asset-Based Welfare: International Experiences, London: IPPR, pp. 55-73.

Management and Coordination Agency (1998) Land and Housing Survey, Tokyo: Management and Coordination Agency. 
Ministry of Finance (2001) The Taxation System in Japan 2001, Tokyo: Ministry of Finance.

Ministry of Health, Welfare and Labour (2000) Kokumin Seikatu Kiso Chosa (Basic survey on the life of people), Tokyo: Ministry of Health, Welfare and Labour.

Ogawa, N. (2001) Nagabiku keiki fuan ga shusseiritsu wo teika saseru (Prolonged recession brings the fertility rate down), in S. Kawamoto (ed.) Ronso Shoshika Nihon (Debate: Low Fertility Japan), Tokyo: Chuo Koron Sha, pp. 79-88.

Okuda, K. (1999) Nihon ni okeru reverse mortgage no genjo (Reverse mortgage schemes in Japan), Yusei Kenkyusho Geppo, 1999(9): 109-14.

Pannell, B. and Heron, J. (2001) 'Good bye to buy-to-let?', Housing Finance, 52, London: CML.

Parsons, W. (1995) Public Policy: An Introduction to the Theory and Practice of Policy Analysis, Cheltenham: Edward Elgar.

Paxton, W. (ed.) (2003) Equal Shares? Building a Progressive and Coherent Asset-Based Welfare Policy, London: IPPR.

Peng, I. (2002) Social care in crisis: gender, demography, and welfare state restructuring in Japan, Social Politics, 9(3): 411-43.

Regan, S. and Paxton, W. (2001) Asset-Based Welfare: International Experiences, London: IPPR.

Royal Commission on Long Term Care (1999) With Respect to Old Age: Long Term Care - Rights and Responsibilities, London: HMSO.

Seikatsu Hogo Hoki Kenkyukai (2003) 2003 nen-ban Seikatsu Hogo Kankei Horei Tsuchishu (2003 Public Assistance Related Laws), Tokyo: Chuo Hoki.

Sherraden, M. (1991) Assets and the Poor: A New American Welfare Policy, New York: M.E. Sharpe.

Sherraden, M. (2003) Assets and the social investment state, in W. Paxton (ed.) Equal Shares? Building a Progressive and Coherent Asset-Based Welfare Policy, London: IPPR, pp. 28-41.

Statistics Bureau (2001) 1999 Zenkoku Shohi Jittai Chosa (National Consumption Survey), Tokyo: Statistics Bureau.

Tachibanaki, T. (2004) Kakei kara Miru Nihon Keizai (Analysing Japanese Economy through the Lenses of the Household Economy), Tokyo: Iwanami Shinsho.

Titmuss, R. (1958) Essays on 'The Welfare State', London: George Allen \& Unwin. 


\title{
6 Housing, family and gender
}

\author{
Mieko Hinokidani
}

\section{Introduction}

The housing system in Japan which formed after the Second World War was based on a modern family norm that led to the overwhelming provision of housing for 'standard families', consisting of an employed husband, a homemaker wife and two children. This system transformed the Japanese housing landscape to a great extent, though assumptions about 'standard families' have not necessarily corresponded to the actual residential practices of the Japanese. Current sociodemographic changes demonstrate a rise in non-conventional households together with an increasing diversity of lifestyles, which contradicts concepts of homogeneity and standardization, and may conflict with dwelling design as well as housing systems developed for 'standard families'.

This chapter begins by looking at incongruities between household composition and housing system norms. It goes on to examine present housing conditions and forms of living from the perspective of women. Literature on gender issues in relation to the physical environment have been well documented among western housing scholars, planners and designers for the last two decades. They have paid attention to the diversification of roles for women as well as gaps between the physical environment and the needs of women (Hayden, 1981, 1984; Van Vliet, 1988; Little, 1994; Ottes et al., 1995; OECD, 1995). These studies have revealed that women have played not only passive roles as consumers, but also active roles in movements seeking change in housing and the environment (Gilroy and Woods, 1994). Women have generally asserted the need for the physical environment to be more secure and for provision of affordable housing and daycare centres near residences. These are considered important conditions in the reconciliation of domestic affairs with the demands of working life engaged in outside of the home.

It seems that there are many common features that women have experienced in the built environments of different countries. However, the response of each society is varied and has depended on the features of the built environment as well 
as on the social norms and gender role definitions. Social responses and discourse concerning the problems that women face within their daily lives reflect socioeconomic conditions and availability of other sorts of resources peculiar to each society. Housing conditions and related services may have a significant effect on women's life chances as well as the quality of everyday life. The examination of these issues in terms of empirical realities and a comparative framework may contribute to greater understanding of future housing demand and the necessary direction of housing policy.

\section{The family norm and modern living}

The modernization of Japanese housing seems a unique and complex process. For a long time, modernization has been equated with the introduction of 'western styles', which was linked to the image of being better-off for many Japanese (Ota, 1969). For the newly emerging middle classes in the pre-war period, the adoption of western-style modern living was regarded as a way not only to improve their daily lives, but also to express their social success. Western-style modern living has thus been regarded as a status symbol among Japanese and for this very reason that way of life rapidly expanded in Japan (Matusbara, 2001).

Other factors that promoted the modernization of forms of living were massive housing construction after the Second World War and the high economic growth period, which enormously transformed the Japanese housing landscape and modified the original images of a modern life (see Ronald, in this volume). The period immediately after the war was characterized by housing shortages, and priority was put on reconstruction projects. The modernization of housing production systems was also imperative in order to make up for the housing deficit.

Traditional dwelling plans and interior arrangements, following the paterfamilias principle, were regarded as forms that needed to be modernized at that time (Hamaguchi, 1949). The dwelling type denoted 'n-DK', which is composed of multiple separate bedrooms, their number expressed by ' $n$ ', with dining kitchen (DK), was introduced in the early 1950s as a modern Japanese dwelling form and expanded in response to increasing housing demands at the time. The prototype in the early days was proposed by housing scholars and technocrats who worked for public housing supply bodies. The ' $n$-DK' style dwelling was a solution to modern functional dwelling for single families with a minimum of available space. Although the influence of western-style modern living was already evident in the design of some newly built detached houses for single families in the 1920s, the introduction of the ' $\mathrm{n}$-DK' style dwelling accelerated the transformation of Japanese urban housing.

Along with the rise of democracy, the share of a nuclear families fitting the model of 'standard families' reached its peak at the end of the period of high 


\section{Mieko Hinokidani}

economic growth. The newly developed dwelling model had been expected to reduce domestic tasks engaged in by women through the introduction of functional dining kitchen facilities. The separation of sleeping place from dining room was a principle of the ' $n$-DK' dwelling which made residential life more rational too. In parallel with the diffusion of western influenced living arrangements, living practices based on the paterfamilias norm were gradually transformed. Elements of urban lifestyles also extended to people living in the countryside with traditional living arrangements who were influenced accordingly.

The ' $n$-LDK' style dwelling, adding a living room (L) to the 'n-DK' model, appeared along with the enlargement of the dwelling size. The previous family room, called a chano-ma (Japanese-style dining living room), was gradually replaced by a western-style living room (Nishikawa, 1998). The 'n-LDK' style dwelling has comprehensively penetrated the design of newly built houses for sale, especially those in the big city suburbs, and represents the ideal home for 'standard families'. The modern family norm has played an important role in their design. These dwelling models prioritize privacy in family life, which is a distinct feature that is divergent from traditional dwelling design. The n-LDK style dwelling has been considered functional modern living, fitting the norm of the modern family.

However, the ' $\mathrm{n}$-LDK' model did not completely transform the design and value system associated with Japanese houses. Among others, local traditions, linked to the social life in each region, have played an important role in the design of newly built houses. The enlargement of dwelling size has made it easy to realize a dwelling containing both modern living and spacious traditional Japanese-style rooms used for guests and family events. Since the second half of the 1970s, housing scholars have paid much attention to local dwelling designs and how they conserve some traditional aspects. Their findings reveal that the modernization process in local housing has been different from the ones observed in the big cities (Sumita, 1983).

Meanwhile, lifestyles based on the assertion of the modern family norm have not prevailed, even in the big cities where ' $\mathrm{n}-\mathrm{LDK}$ ' style dwellings have been most abundant. It is interesting to note that aspirations for ' $n$-LDK' style housing are strongly tied to the desire to secure sufficient numbers of independent rooms for children. Indeed, considerable effort has been made by most families to provide independent rooms for children even though the available floor area is considerably limited by western standards. It has been most imperative to secure enough independent rooms for children of school age. The arrangement of living space has thus been conducive to the promotion of individualization of living units.

It is worth noting that in 1968, during the period of high economic growth and when the proportion of standard nuclear families attained its peak, the Japanese architect Takashi Kurosawa argued that modern housing linked to the 
modern family norm was not a sustainable model and would eventually collapse (Kurosawa, 1968, 1997). It is doubtful whether he was aware that unsustainability derived from the implicit contradiction, from the perspective of gender, in the modern family norm. What he thought irrational at that time were the assumptions concerning the residential life of couples. Instead of modern living, he proposed the compartment group dwelling, composed of an aggregation of independent rooms for each individual. In his model, a couple composed of a husband and a wife were considered two different individuals who should have a separate room each.

Kurosawa provided a keen critique of the 'n-LDK' style dwelling in terms of contradictions of the modern family norm, but he did not receive broad support at the time. His plan anticipated, however, drastic changes in communal life mediated and managed by the family. The increasing number of separate rooms has largely enabled each individual to secure an independent living space, even for husbands and wives. Indeed, it has been observed that Japanese couples were accustomed to sleeping separately, even though they did not have separate bedrooms. This kind of daily practice has led to a new dwelling style. Since the 1980s, dwelling units that facilitate multiple direct accesses from the outside to independent rooms within the house has been proposed and in some case already realized (Yamamoto, 1993; Shinohara et al., 2002; Takada et al., 2005).

The changing processes within Japanese housing have been led by the modernization of residential life based on the patriarchal family norm together with other traditional forms. Conventional dwellings were replaced by n-LDK style dwellings, which were associated with an aspiration towards a modern family norm (Yazawa, 1996). The penetration of the modern lifestyle has not changed dwelling design associated with the previous family norm completely and alternative living models have appeared in parallel with its expansion (Nishikawa, 2001). The diversity of lifestyle and the individualization of living units have, arguably, key relationships with this process.

\section{Individualization of living units}

In the 1980s, most western industrialized countries experienced decline in the proportion of a nuclear families with dependent children, while, the volume of other types of households, such as one-person households and one-parent families has expanded rapidly. Accordingly, the growing awareness of the increase of nonconventional households has led criticism of the lack of housing fitting contemporary needs. Instead of the dwelling model suited to the conventional family household, an alternative one has been proposed in response to changes. The relatively high housing costs compared with income level among non-conventional households, including women-headed ones, have thus been increasingly considered one of the most important issues in housing policy. 
Japan, too, has experienced the decline of 'standard families' for the past two decades and in this process the proportion of one-person households has starkly increased. Although their percentage is still low compared to western countries (e.g. 36 per cent in Germany, and 31 per cent in the UK and France), the 2000 Population Census of Japan identified a level of 27.6 per cent. Due not only to ageing of the population and greater longevity, but also the diversity of lifestyles of all age groups, the size of households continues to diminish. By 2025, the share of one-person households among total households is projected to reach nearly 35 per cent according to the National Institute of Population and Social Security Research (2003). The reduction of household size together with the decline of family households with dependent children will continue and perhaps will be accelerated in the near future. Instead, non-conventional households, especially one-person households will expand along with the postponement of marriage, the decline of the birth-rate and increases in the numbers of those who never marry. Such estimates will impact on household formation and, subsequently, will strongly influence future housing demands.

It seems that lifestyles have been progressing along with the individualization of living units. There are not simply independent household units containing singles, but many potential types of living alone even in family households. For example, young adult children, who live with their parents in a detached house containing independent rooms separated from other living spaces, may tend to individualize their use of time and space. Japanese modern living which emphasizes privacy and individual lifestyle consumption is highly suited to this way of living. The diffusion and personalized use of electronics such as a televisions and mobile phones has also stimulated self-sufficient lifestyles. Urban residents, especially those who live in the big cities, can easily get necessary services from outside of the home. The developing system of goods and services may make it easy to live alone. In this regard, it seems that Japanese cities are much more advanced compared to those in other industrialized countries.

This trend has generated a new dwelling type. Since the end of the 1970s, oneroom type dwelling units have been provided en masse for single persons living alone. Their habitable floor area is tiny, but contains all necessary amenities such as toilet, bathtub and shower, cooking facilities and independent access from the outside. The one-room accommodation looks like a self-sufficient dwelling unit impossible to further sub-divide, which can be described as a dwelling form made by compressing a modern apartment unit into its ultimate compact size. Living in such a small dwelling without shared communal facilities adds to the increasing sensitivity to privacy and the autonomy of individual life among urban residents.

Nevertheless, the individualization of living does not contradict family values to the extent that the maintenance of psychological relationships are more important to the consolidation of family ties than material reciprocity strengthened through practices of living together. Among urban residents, the presumption that home 
is a place exclusively for communal life has been increasingly losing salience. This is particularly true in the Japanese case, where forms of scattered living have been widely observed in accordance with the increasing numbers of employed married men sent on company transfers during the period of high economic growth. The husband-alone transfer has been accepted among ordinary modern families in order to maintain a good educational environment for children or/and needs to care for the elderly. Recently, not only husbands but also employed wives are living alone, apart from their own family, in order to pursue a professional career. Although it is difficult to count their numbers, such a lifestyle seems to be expanding among women with professional careers.

Some housing scholars have called the scattered residential practices of families 'network living' because each family member keeps intimate mutual interrelations even though they are living separately (Kim and Omi, 1994). 'Network living' may be regarded as a solution or reconciliation of values attached to individual lifestyles with the dominant family norm of the society. It seems that such lifestyles have been spreading even in a society where the values of family ties are strongly maintained.

Another aspect that promotes the individualization of living may be the increasing number of the 'never-married' and divorced. As I will examine further, never-married persons have increased among all age groups. Young persons living together with their parents, for example, enjoy better living conditions in terms of available space per person in comparison with those who belong to the same cohort but have started a family. The lack of effective housing policy measures addressed to young family households, as well as general social policy certainly affect people's choice of residence and household composition. The number of divorced persons is also expanding. Along with the decline of the material reciprocity of assistance, it has been observed that family ties might become fragile and broken by unexpected events. The social responsibilities of caring for people who need looking after increase pressure on families and relationships.

The quality of residential life depends to a great extent on the availability as well as affordability of social provision of necessary services. The income level of one-person households is generally lower than that of other types of household. Unlike other advanced countries, which have been aware of the increase in nonconventional households and have tried to adjust housing systems in order to meet changing needs, public policy in Japan has not paid enough attention to this phenomenon. Although the provision of one-room type accommodation has been largely a response of the market to demand for privacy and individual living, in reality, it also attracts those on low incomes and rent levels have had to adjust to people's ability to pay.

For the market, reducing the quality of dwelling units may be a rational response. This solution, however, has brought about new social conflicts and tensions. Closed dwelling designs with poor living conditions tend to isolate 
inhabitants from the local community where the building is located. Some neighbourhoods have organized protest campaigns against housing projects which intend to provide one-room-type accommodations exclusively and have requested that local governments not grant construction permission. For instance, Tokyo Metropolitan Government reported increases in neighbourhood objection to the building of such dwellings (2004: 40-1). People living in such accommodation are often regarded as benefiting from urban living at least expense to themselves.

The prevalence of one-room-type accommodations raises many questions about the design of dwelling as well as community life (Takada, 2002). The support of community life is not only crucial for women with caring responsibilities but also for children, the elderly and handicapped people who require local networks of care and support. The rapid transition of the Japanese housing landscape and the problems raised in this process imply that the housing supply system in Japan has been flexible but has produced undesirable effects on community life and the built environment in the long run.

\section{Housing conditions and household types}

Housing conditions have a great influence on the formation of households, and the availability of housing as well as its affordability largely determines lifestyles. The national housing survey conducted in 2003 shows that the number of dwellings nationwide has continued to increase and that they exceed the number of households. The rate of 423 dwellings per 1,000 inhabitants is almost the same as the level in the Netherlands and the UK. Empty units are increasing not only in the countryside but also in big cities such as Tokyo and Osaka, where the vacancy rate has reached around 10 to 15 per cent. For the last three decades the housing situation has been changed to a great extent in terms of quantity.

Evidently, massive new housing construction over a period of years brought about this change. More than 50 per cent of housing stock has been built since 1981, which contributed to the improvement of housing quality. Housing size, an important indicator of quality, has steadily grown and reached almost the same levels as in major European countries. In addition, as the number of persons per household has decreased, occupation density has improved substantially. As a result, households living in dwellings of a standard below minimum housing standards set by the Japanese government decreased in 2003 to 4.3 as a percentage of total households, compared to 30.4 per cent in 1973.

However, this general picture conceals a considerable disparity in housing conditions between different household types. Among other factors, age of householders as well as the household size is significant. For instance, young householders live in relatively small accommodation compared to the elderly. Among elderly households, many live in large dwellings disproportionate to relative household size. Such disparities tend to expand in accordance with recent 
socio-demographical changes as well as in relation to adjustments in housing tenure patterns, which I shall consider shortly. The quality of dwelling units that one can secure depends largely on the place where one lives. For instance, those who are moving or forming a new household in big cities are often confronted with the difficulties of getting a dwelling unit of adequate size and with appropriate living conditions. The degree of urbanization measured by variables such as population size and urban density remains significant and explains many disparities in housing conditions.

Disparities in housing can be seen most clearly between different housing tenures. For instance, since 1973, the average unit size of an owner-occupied dwelling has been 2.5 times or more of that of the rental dwellings (see Figure 6.1). Not only in private rental housing, but also in public rental housing there is a deficit in numbers of large dwelling units for family households. Rental housing is still orientated towards small-size units and thus cannot satisfy living needs of households composed of three or more persons.

Generally, there are trade-offs between the size of dwellings and their location and thus those who are living in rental units in the cities lose out in terms of dwelling space. In theory, if they are really 'choosing' such living conditions, they should be satisfied with their choice to the same extent as those who live in owner-occupied dwellings. According the 'Housing Demand Survey' conducted periodically by the government, however, those who live in rental units are much more discontented with their housing conditions compared to those living in owner-occupied dwellings. It suggests that rental dwellers are not freely choosing their dwelling form, but rather are constrained in choosing by the lack of options available to them (Hinokidani, 2004).

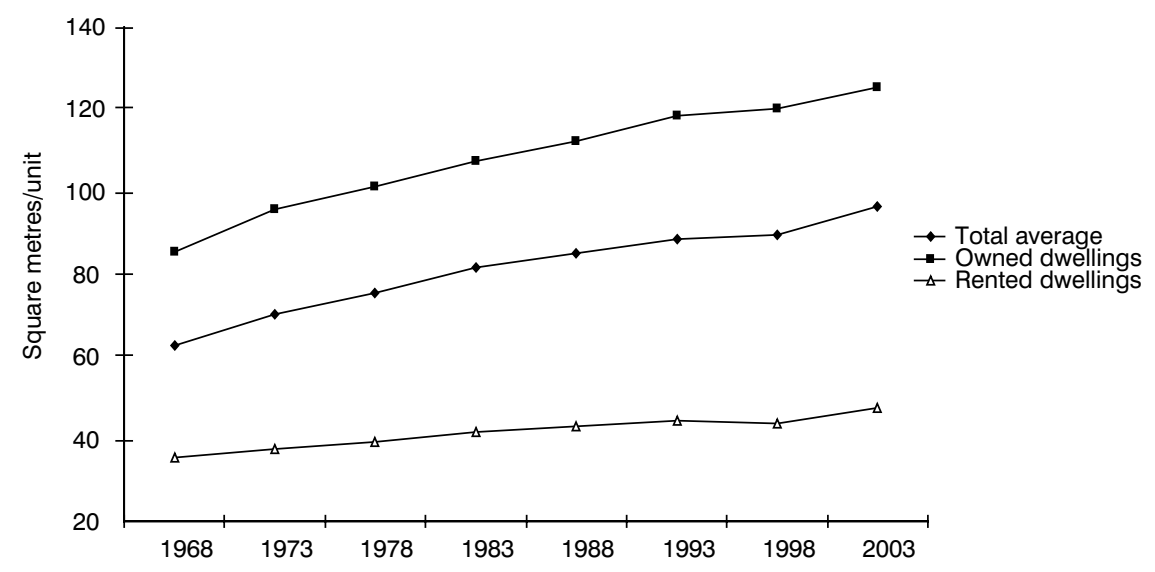

6.1 Average floor space per dwelling by housing tenure Source: Statistics Bureau, 2003 Housing and Land Survey of Japan. 


\section{Mieko Hinokidani}

Measures of housing conditions by household type also indicate that there is wide mismatch between the size of household and the size of the dwelling unit. Young households tend to live in small rental units while the elderly live in large owner-occupied ones. For the last 25 years, this trend has been reinforced as the number, as well as proportion, of young householders moving into the owneroccupied sector has diminished, while that of the elderly has increased. The huge disparity between owner-occupied and rental housing may constrain young people who wish to start a family or form a new household, but who cannot afford to buy a house immediately.

Statistical evidence also indicates that among about 2 million households who cannot find housing that satisfies the minimum housing standards, as defined by the Japanese government, 80 per cent are found in rental dwellings and more than one-third of such households are one-person households. The minimum space applied in these guidelines for one-person households is usually 18 square metres ( 25 in the case of the elderly). This implies that one-person households have to accept extremely low housing standards. It is interesting to note the case of UK where one-person households living in private rental housing have in excess of 50 square metres in average floor space, while the comparative figure is only 32 square metres in Japan. Large family households have difficulty in satisfying minimum living standards if they are accommodated in rental dwelling. It is significant that among households living in public rental housing, quite a large number of households are composed of four or more people living below minimum standards (Figure 6.2).

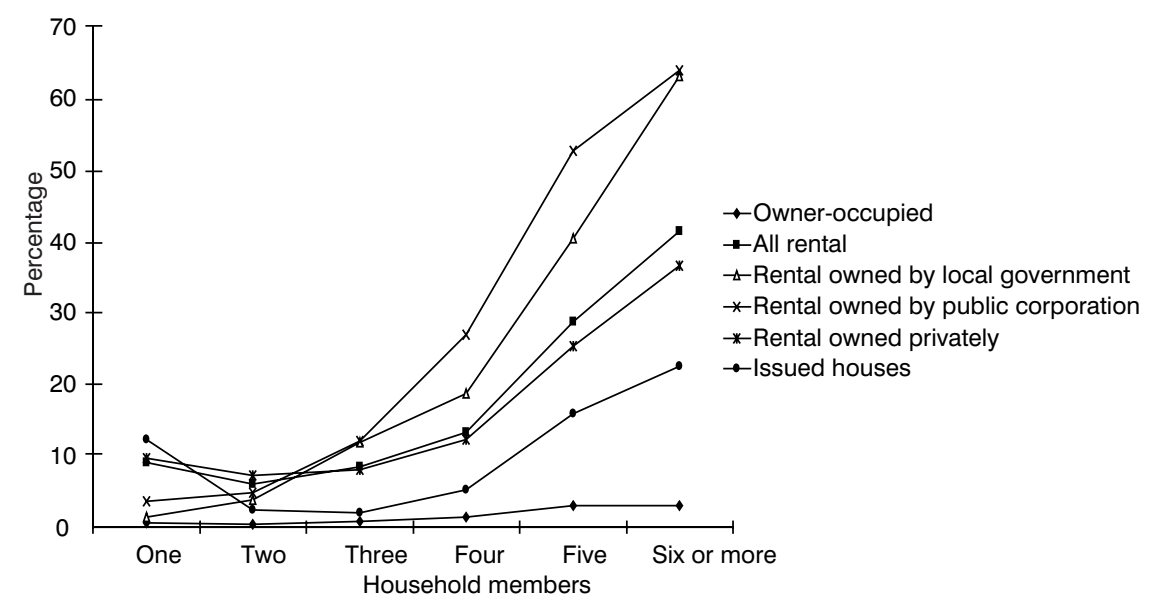

6.2 The share of households below minimum housing standard by number of household members

Source: Statistics Bureau, 2003 Housing and Land Survey of Japan. 
The housing conditions of urban rental households are in general determined by the rent level, which may impede those on low incomes in accessing decent dwellings. Therefore, most advanced countries have introduced housing allowance or housing benefit systems, in order to improve their ability to pay, which have replaced the social housing supply programme and/or rent control legislation applied to private rental dwelling. In the case of Japan, however, the central government has never been eager to supply public housing on a large scale, nor to introduce a housing allowance system as a universal service for those who cannot find adequate housing. As a result, it may be difficult for the urban poor to afford decent houses with affordable rent. For example, in comparison with the English case where low-income households can enjoy significant rent rebate through the housing benefit system, low-income households must bear relatively high housing expenses against their income in Japan, where allotments of housing allowance are too little and limited only to those who are subject to the Living Standard Protection Act.

\section{Women's life chances and residential patterns}

It seems that women have played an important role in current socio-demographic changes. The universal validity of the 'traditional' life-course for women, based on the marriage and mothering norm as well as the assumption of the 'standard families' model, has come into question with the increasing number of employed women as well as a rise in consciousness concerning marriage norms and gender relations.

In the case of Japan, the socio-economic changes of the last two decades have made it difficult for women to stay at home as housewives and/or work as neighbourhood volunteers. The rise in the number of employed women is significant (Figure 6.3). It indicates, not only for each household but also for society, that maintaining the sole male breadwinner model has become difficult. Both married and 'never-married' women have been increasingly expected to work outside of the home and to complement the earning of the head of household. The rise of education costs for children and the burden of housing loans have also stimulated the need for women to work outside the home.

Although the political and legislative efforts to correct unequal treatment by gender have been in force since the 1980s, men and women have not able to choose their lifestyle equally in most countries. In general, women are less integrated into paid work and their wages are lower than those of men. With the growing awareness of the discriminatory treatment that women face within paid employment, gender related barriers across the labour market have been removed steadily, and caring responsibilities have been increasingly redistributed through the introduction of social care services available for employed women. In addition, in some countries the urban and housing environments, which were formed in 


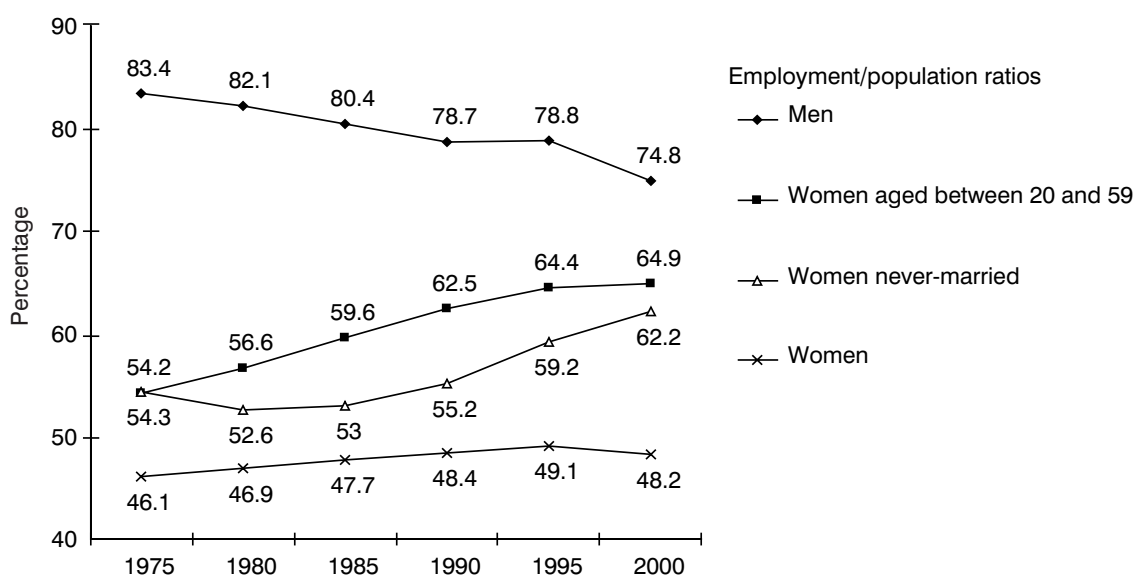

6.3 Ratios of employment of women between 1975 and 2000 in Japan Source: Statistics Bureau, Employment Survey and Census.

accordance with the gender division principle, have been revised and the location of employment and housing changed accordingly.

It has been supposed that women's life chances may not expand without the public policy measures mentioned above, and that Japan lags behind in these terms compared with the EU countries. For example, urban patterns which compel people to commute for long distances constitute a barrier for employed women by making a professional career and a home life incompatible. Also, the lack of decent and affordable dwellings in cities makes it difficult to secure a convenient dwelling for women whose living needs are different from those of men.

Indeed, it is significant that there are considerable disparities in women's situations across countries, even though women's life chances seem to be improving in parallel with the promotion of gender equality policies in every country. The available statistics indicate that the North European countries are moving ahead, while women in Japan remain in a relatively more disadvantaged position (Table 6.1). For instance, on average, Japanese employed women get only 66.8 per cent, on average, of the wages of employed men (MHLW, 2003). The proportion of employed women aged 25 to 54 is more than 77 per cent in Sweden, Denmark and Finland. Alternatively, the share in Italy, Spain, Greece, Ireland, Luxemburg and Japan is less than 63 per cent. In addition, more than 40 per cent of Japanese employed women are part-time workers and earn much less than full-time workers (OECD, 2004).

The diversity in the types of household that women form correlates highly with the rate of employed women. It seems that women may choose their housing and household composition among broad and realistic options in countries where women are economically self-sufficient and there is a lower disparity in 


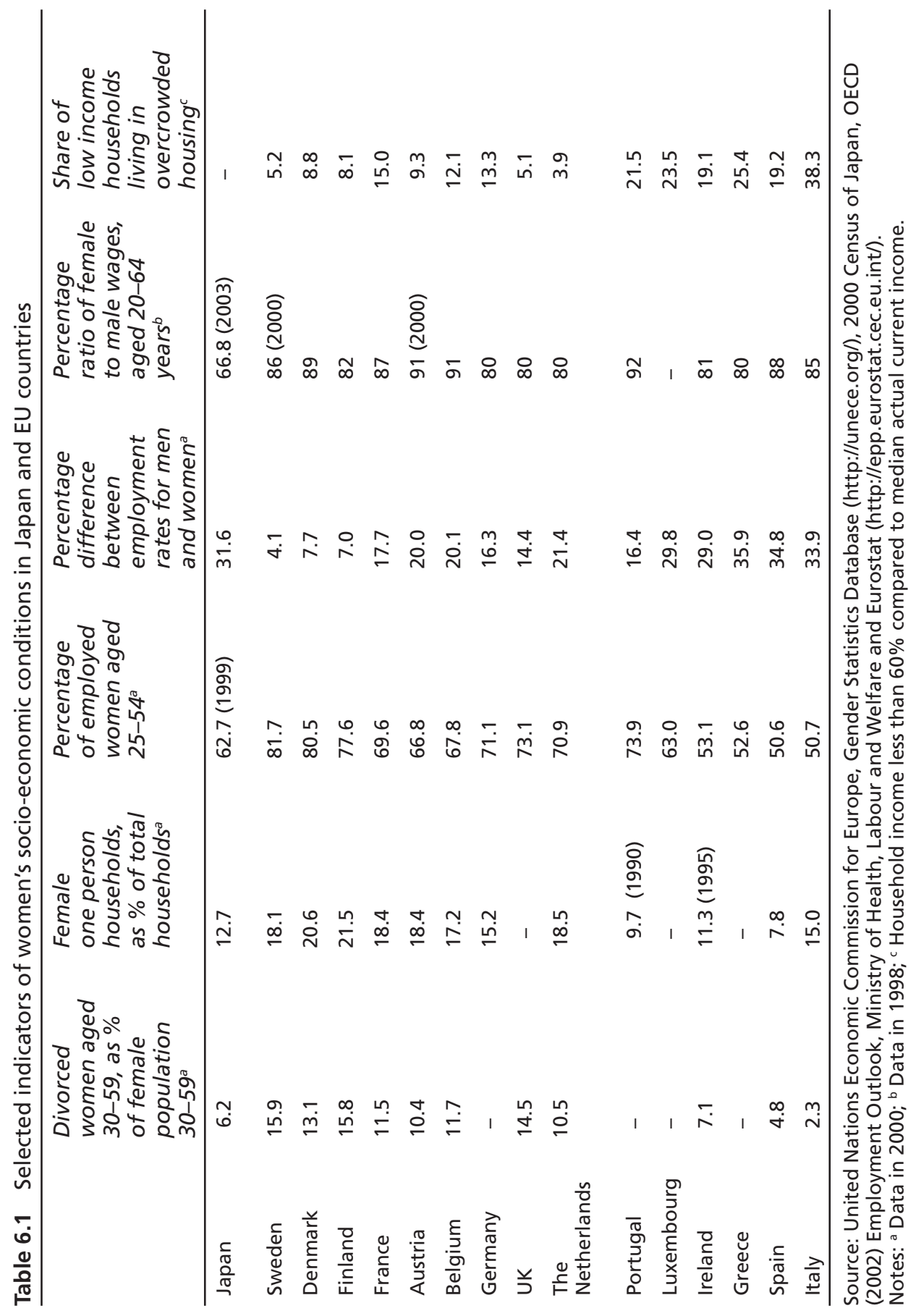


wages between men and women. For instance, in Sweden, Denmark, Finland, UK, Belgium, France and the Netherlands, more than 10 per cent of women aged between 30 and 59 are divorced, while 6.2 per cent are divorced in Japan. Furthermore, female one-person households as well as women living together with a partner are more represented in the former countries. In Ireland, Spain, Italy and Japan, women-headed, one-parent families are few and the birth-rate is low (UN, 2005; Gender Statistics Database of UNECE).

Although these statistics indicate that the increasing number of employed women together with less disparity in wages by gender may be linked to the emergence of new lifestyles, it is not accurate to say that more integration of women into paid work will expand their life chances. Without social support for caring responsibilities, living with dependent children or with frail elderly parents may become problematic for employed women. It also depends on the availability of other resources such as informal aid through social networks or kinship. In contrast to the Japanese case, in a society providing both equal opportunities in the labour market and necessary support in caring for family members, women may be in a better position to determine their own lives. High integration of women into paid work is frequently concomitant with solid social support and care systems. Countries such as Sweden, Denmark and France correspond to this model. The correlations between diversity in household compositions and the increase in self-sufficient women suggest that the life chances of women may depend not only on socio-cultural settings but also the performance of gender related public policy measures, of which housing policy composes an important part. The North European countries and some countries with strong social housing traditions enjoy relatively better housing conditions and disparities in housing conditions in terms of overcrowding and between different income groups are small.

Indeed, the problems that women in Japan face are strongly reflected in their household composition and housing conditions. Women-headed households represent only about 20 per cent of all households and single women are the largest component among them. The proportion of one-person households is 62.8 per cent for female-headed households, compared to 18.7 per cent for male-headed households. In real numbers, however, male one-person households account for about 7 million households compared to 6 million for female ones (Table 6.2). In addition, female one-person households are made up of largely elderly women, while, among women aged between 15 and 59 years old, their number is almost half of that of male one-person households.

In fact, single women living alone are not in the majority. Unmarried or nevermarried women tend to live with their relatives. According to the 2000 Census, more than 70 per cent of women aged between 15 and 24 live with their parents and even among women aged between 25 and 34, 28 per cent live with their parents. In contrast 10 per cent of the latter group live alone as a one-person household, while 55 per cent live as a married couple with or without children. 
Table 6.2 Household by family type

\begin{tabular}{|c|c|c|c|}
\hline & Male-headed & $\begin{array}{l}\text { Female- } \\
\text { headed }\end{array}$ & Total \\
\hline $\begin{array}{l}\text { One-person household (age } \\
\text { of householder) }\end{array}$ & $6,978,733$ & $5,932,585$ & $12,911,318$ \\
\hline 15-39 years old & $3,944,677$ & 215,083 & $4,159,760$ \\
\hline $40-59$ & $1,987,122$ & $1,078,914$ & $3,066,036$ \\
\hline 60 and more & $1,046,934$ & $2,738,588$ & $3,785,522$ \\
\hline $\begin{array}{l}\text { One-parent nuclear family } \\
\text { household }\end{array}$ & $1,008,092$ & $2,569,639$ & $3,577,731$ \\
\hline $\begin{array}{l}\text { Households with child(ren) } \\
\text { under } 17 \text { years old }\end{array}$ & 112,173 & 883,549 & 995,722 \\
\hline Couple only & $8,764,944$ & 70,175 & $8,835,119$ \\
\hline $\begin{array}{l}\text { Nuclear family household } \\
\text { with child(ren) }\end{array}$ & $14,856,180$ & 63,005 & $14,919,185$ \\
\hline Other family household & $5,589,021$ & 758,230 & $6,347,251$ \\
\hline Other household & 137,872 & 53,907 & 191,779 \\
\hline Total & $37,334,842$ & $9,447,541$ & $46,782,383$ \\
\hline
\end{tabular}

Source: 2000 Census of Japan.

The choice to live alone is often a heavy financial burden for women, excluding those who are already paid-up owner-occupiers. The average housing expenditure among one-person households is quite different between men and women. According to the National Survey on Living Expenditure in 1999, women-headed one-person households aged below 60 years spend more for housing in spite of earning less than men. For instance, women under 30 years old spend about 24.4 per cent of their total outgoings on housing, while men spend about 14.7 per cent. Women living alone have been spending more money for housing in total as well as in proportion to their income for the last 20 years.

The reason why women living alone spend more money for housing than men may relate to their preference in housing location. Women tend to prioritize security and convenience and choose to live close to local stations in central areas of the city. Their choice also corresponds to their employment status. The majority of women living alone in cities are employed in either professional or service sectors. For both, the reduction of commuting time is essential. In big cities such as Tokyo and Osaka, female one-person households are more concentrated in the central areas of the city, compared to male one-person households whose location is more diversified (Wakabayashi et al., 2002; Yui et al., 2004). The rent in the central part of the city is much higher than that of the periphery. Women in 


\section{Mieko Hinokidani}

rental dwellings have thus been forced to accept higher housing costs relative to a mediocre quality of housing. The discriminatory practices of some landlords have also undermined women's options in living alone.

Under such conditions, the decline of land prices together with increases of women with well-paid jobs has stimulated the housing supply in central parts of cities for the last decade. Single women are among the major buyers of newly built condominiums and there are even customized financial services for women looking for loans with affordable interest rates. Although high-rent housing conditions have pushed women into buying condominiums, the majority of young and middle-aged women living alone are likely to be unsatisfied with their present living conditions. It has also been pointed out that, compared to women living with their parents, young women forming one-person households, on the whole, are less satisfied with their present living conditions (COGJ, 2003: 104-6).

Another important type of woman-headed household is the one-parent family. Compared to the other advanced countries, the share of women-headed oneparent households in Japan is relatively small, representing about 4 per cent of households with children. However, the recent increase in divorce, desertion and domestic violence has led gradually to accelerating formation of women-headed one-parent households.

For many lone mother families, including those living with relatives or friends, it is not easy to secure independent living space. Generally speaking, structural disadvantages faced by women, as reflected in their position in the labour market as well as the cultural norms of mothering, act as constraints in accessing decent,

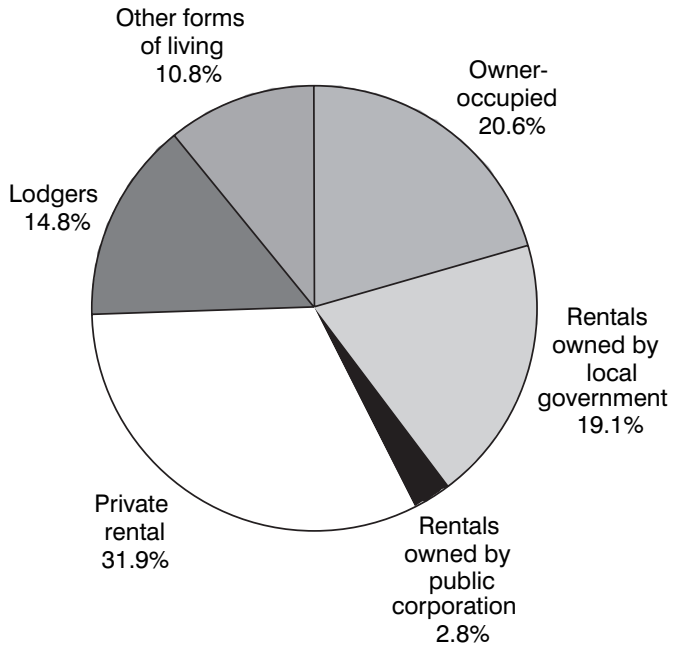

6.4 Distribution of housing tenure, lone-mother families, 2003 Source: Ministry of Health, Labour and Welfare 
affordable self-sufficient dwellings. In addition, available public assistance and benefits available to lone mother families are still limited and tend to be concentrated in scope and distribution. Housing has not been examined sufficiently as a possible form of public assistance. Although low-income lone mother families constitute a priority group in the allotment of public housing, it does not provide a comprehensive solution to the problem. In addition to the scarceness of available public housing units, because of their location far from urban centres and/or lack of available services for childcare, lone mother families living in public housing estates often find it difficult to access an appropriate job, even part-time.

Due to the scarcity of available social housing and their disadvantaged location, private rental units accommodate a large number of women-headed one-parent households. Those who cannot afford to access private rental housing turn to institutional support or share dwelling units with relatives or others. At present most lone mother families live either in private rental or public rental housing. Only 20 per cent of them are found in the owner-occupied sector (Figure 6.4), while about 25 per cent of them do not reside in an independent dwelling. Linked to the distribution of housing tenure, women-headed one-parent households hold less living space compared to conventional family households. Those lone mother families who can benefit from housing allowance fall under the limited umbrella of the Living Standard Protection Act. In consequence, the majority of womenheaded one-parent households live in mediocre dwellings with high housing expenditure relative to their current income.

\section{Lone mother families and institutional living}

The Dormitory for Mothers and Children, is the former name of the Life Support Centre for Mothers and Children (LSCMC), and is a rare resource provided for lone mother families. It was introduced immediately after the war in order to provide lone mothers with accommodation and childcare services. At first, the beneficiaries were mostly war widows and public assistance was justified in terms of child welfare needs (Hayashi, 1992). The legal framework of this setup has remained unchanged, while the attributes of beneficiaries have changed more radically. Since the second half of 1970s, divorced women with children have increasingly constituted the majority of residents. Recently women who have run away from domestic violence have been also been increasing in number and the LSCMC has provided newcomers with not only shelter but also other necessities such as refrigerators, electronic cleaners, tables, chairs and bedclothes along with many other kinds of consumable goods.

Presently, there are around 300 LSCMCs which accommodate about 2,000 families. Considering the increasing needs for shelter among lone mother families, the number as well as the capacity of the centres seems modest. Job opportunities as well as availability of neighbourhood assistance depend largely on the attributes 
of the community where the LSCMC is located. Previous studies have pointed out that there is a strong correlation between the location of the LSCMC and the types of employment that their residents can find (Social Welfare Board of Aichi Prefecture, 1984). The advantage of having LSCMCs located in the central areas of big cities is enhanced mobility and the reduction of commuting time.

The building of an LSCMC usually consists of entrance hall, living units for each household, nursery room, study room for children, meeting room, counselling room, staff room, and communal bath or shower room in cases where each living unit does not have a private one. Study rooms for children and meeting rooms are included following legislative rules. In terms of size, favourable attention is paid to the study room, which is often the biggest room in the building after the independent day nursery attached to the LSCMC. Children of school age can be found playing and studying there until 6 o'clock in the evening on weekdays.

The legal minimum building standards applied to the living unit for each family consist of the following two conditions. First is the requirement for more than 3.3 square metres per person and second is the need for more than one room per family. The minimum living conditions applied to each compartment of LSCMCs are admittedly much lower than the ones applied for a normal dwelling unit. In addition to the lack of living space, a prefixed floor plan following the 'modern living' principle does not allow for high-quality living. Some shared communal rooms are well equipped but used for only several hours on weekdays. The lack of private facilities such as bathrooms is regarded in most cases as a major problem. It seems that shared communal facilities fail to compensate for the smallness of living units and are inadequate as places for enriching communal life.

The objective of the installation of the LSCMC has been to provide children with a sound growing environment by assuring that they can live together with their mothers. Accordingly, the kinship between mother and children is highly respected and this view is reflected in the support programmes as well as the conduct of the staff. Each family is expected to organize their daily life by themselves and collaboration with other families is largely frowned upon. Residents are responsible for domestic affairs and additional support is not offered except daycare for children. Preparing meals, washing clothes, cleaning and so on are the responsibility of each family. Mothers are also expected to spend as much time as possible with their children. As childcare services are only provided in the daytime, mothers working outside the LSCMC must come back early. Such conditions may constrain women's choice of work. Another important point is that the beneficiaries of the LSCMC have to move out to a normal dwelling unit as soon as possible, because the LSCMC is considered temporary accommodation.

Inevitably, as the LSCMC is multi-family accommodation with communal facilities, residents need to organize their daily lives in collaboration with others. They often share responsibility for daily maintenance of the building and communal facilities. Residents are requested to collaborate with others for 
practical reasons on the one hand, but restricted in developing intimate relations, at least inside the LSCMC, on the other. Due to such circumstances, life in the LSCMC is usually considered unpleasant for residents. Nevertheless, it should be noted that the on-site services provided by the LSCMC have many advantages that cannot be substituted. For instance, the time-saving aspects of on-site services are important. Counselling services for childcare and job seeking are available and residents can access them whenever they need them. In addition, staff members have face-to-face, daily contact with each family, which makes it easy to take measures if necessary and immediately in order to prevent problems occurring (Hasegawa and Hinokidani, 2002).

In terms of both spatial arrangements and available programmes, life in the LSCMC provides children with relatively favourable conditions. The care programmes cover not only children under six years old but also children of school age. Some institutions even have teaching assistance programmes for high school students. These services are available inside the LSCMC building. Facilities for children are usually well equipped. The LSCMC also provides various free events for children, such as birthday parties, seasonal festivals, day trips and so on.

However, due to poor living conditions and communal facilities, institutional living makes it difficult to satisfy women's needs. Furthermore, the present legal framework and normative views on the role of the family and mothers restrain residents from collaborating with others in trying to make communal life more pleasant, despite the relative advantages found in such collaborations.

\section{Women's needs and alternative living}

For women with children, job opportunities depend to a great extent on commuting time and the availability of on-site services for children and the elderly. It is supposed therefore that if housing provision pays attention to women's needs it will be more efficient than the current benefit system in improving conditions. For this reason, a suitable living model for working mothers is required and housing policy should be conscious of their needs.

It has been widely recognized that many women raising young children are heavily dissatisfied with their living environment in cities. Cramped housing along with high living expenses are often seen as key sources of dissatisfaction (Yazawa et al., 2003; COGI, 2005). According to the National Opinion Survey on Lifestyle Preferences, in 2005, more than 60 per cent of young married people aged between 20 and 49 consider that a good parenting environment is the most important criterion in housing choice.

Our questionnaire survey (1995) addressed 252 users of day nurseries located in three different areas including the city centre, a deprived inner-city area and a newly developed residential area of Osaka. The survey indicated that the causes of dissatisfaction with public support schemes differ from place to place, and 


\section{Mieko Hinokidani}

that preferences were linked to the lifestyles of groups of respondents. The major trends are summarized as follows (Fujita et al., 1997; Hinokidani, 1998).

Women living close to city centres often complained about the scarceness of caring services and unpleasantness and inappropriateness of the environment for childrearing. Respondents had moved to the centre of the city in order to reduce commuting time and, in most cases, to get access to the necessary support provided by relatives living nearby. Residential location also reflected status. City centre residents are often well-paid full-time professional workers and thus able to buy necessary caring services where they are available. The situation of women living in deprived inner-city areas was quite different. Most of them, including lone mothers, are employed in the service sector and earn little. They are also dissatisfied with the childcare environment, and wish to improve it. Instead of market services, which usually cost too much, support housing policy measures were preferred that would enable respondents to live together with their parents or near their families' homes so that their parents or relatives could take care of children without remuneration. Most felt they would be better off with a housing allowance to facilitate a move to a larger dwelling. Women living in new towns located in the suburbs far from the city centre, alternatively, did not expect to receive childcare support from relatives living nearby. There were few fulltime workers in these areas and they tended to consider childcare and being a housewife more important than making a professional career. The lack of job possibilities and informal resources are regarded as given conditions. Many such women complained about the inconvenience of their surroundings as well as high mobility costs, and supported the development of mutual aid networks in the neighbourhood among women with similar lives.

Though this simplified overview has reduced the survey to general characteristic features drawn from small samples in a specific region, it may illustrate how women's feelings about the questions of daily life and provisional requirements are different according to their location and experience and in relation to their physical environment. Opinions may have depended to a great extent on the situation of each individual. Nevertheless it affirms the fact that women with children have double loads that restrain their life chances, as opposed to the case of men. In fact, the social salience of gender roles seems to persist despite the increasing number of women working outside of the home. For instance, the Government's 2001 Social Life Survey indicated that married women with a job spend 3.6 hours on housework per day on average if they have children and 2.3 hours if they do not have children, while married men spend only 0.1 hours in both cases (COGJ, 2005: 171). Value systems seem to reflect women's needs in relation to the physical environment, as well as male-dominated forms of residence. Rapid socio-demographic changes have thus managed to progress while conserving women's inferior position (Shirahase, 2005). As indicated in the case of women living in the city centre, without the informal assistance of relatives, especially 
grandmothers, women with children struggle to pursue a professional career. It is widely recognized, therefore, that the mother/grandmother plays a crucial role in the employment of married women (NIPSSR, 2000; COGJ, 2005: 48).

On the other hand, the increasing number of employed women, especially those in professional or managerial occupations, implies that the social value system is in a process of transition, at least for women who are living self-sufficiently. It is supposed that they have a great potential to change gender relations and that their problems in daily life have been driving the search for alternative residential forms and lifestyles.

In Europe and North America architects and housing scholars with feminist perspectives have proposed ideas on alternative dwelling forms. For example, collective housing containing shared spaces and facilities for communal life with self-sufficient dwelling units for each household or co-housing have been developed in Denmark. This approach has now expanded into other countries which seek to develop housing forms which combine the autonomy of private dwellings with the advantages of community living (Franck and Ahrentzen, 1989; McCamant and Durrett, 1994; Vestbro, 1997, 2000; Koyabe, 1997).

Recently, types of 'collective housing' have been introduced as forms of alternative living in Japan. A famous example is found in Kobe's public housing estates built in the reconstruction process after the great Hanshin-Awaji earthquake in 1995. A supply of 'collective housing' with shared communal facilities was provided in order to stimulate relationships between residents (Ishido et al., 2000). Most of them are low-income elderly people and live either as singles or as couples without children. They had lost not only their homes but also their communities and neighbours in the disaster. This programme, based on the assumption that providing a communal space with a central kitchen would promote communal life among the residents, has been highly regarded as a community experiment, although there are many questions over the actual success of this approach.

Compared to men of the same generation, women have tended to demonstrate a stronger desire for self-sufficient living and less expectations of living together with their sons or daughters in future (COGJ, 1996), which may partially explain growing interest concerning this collective living model among women. However, not only elderly but also young women with children have demonstrated interested in these types of lifestyle models.

According to the results of our questionnaire study conducted in 1997, which surveyed 935 women living in Osaka Metropolis, women with heavy childcare responsibilities as well as women over 50 years old living in single-detached dwellings located in city suburbs, show greater interest in communal life and 'collective housing' (Hinokidani and Fujita, 1998; Hinokidani, 1998). The reasons were diverse. Young women with children supported the idea of mutual aid in order to reduce or rationalize their housework through collective services. They also considered that collective housing created a secure and stimulating 
environment for children. Some considered that it might be more important to develop communal life than secure privacy in order to improve the quality of daily life. Those with feminist perspectives also supported the idea that both men and women should be involved in communal life.

Alternative forms of living that facilitate collaborative and more environmentally friendly ways of living have been observed in western countries (Meltzer, 2000). Some of the respondents of our survey demonstrated some similar environmental concerns and pointed out that development of communal life would promote more environmentally sustainable lifestyles through collaborative action, such as making communal space for recycling, etc. In addition, while more elderly women tended to consider collective housing as a residential form which corresponds strongly to the needs of the elderly, they also considered that 'collective housing' offers an alternative living model that enables them to develop social relations among people with similar needs. Accordingly, such housing is expected to promote more associative living with neighbours (Ueno, 1996).

Along with the positive perspectives, our survey also indicated that many women have negative images of communal life. They feel that the balance between privacy and sharing, pressurized by communal living, is delicate. Indeed, some recent shared housing projects have illustrated the problems many people have had adjusting to communal living (Koyabe, 2005). It seems more participative research is necessary in order to grasp the reasons why some residents prefer communal types of dwelling and others are more resistant. Among women who showed interest in shared housing, some simply wanted to feel that others are around and could be found in times of crisis, while others expected more and wished to share communal life with other residents. Especially for women living alone, enhancing feelings of security may constitute a major reason to look for shared housing. The design of shared housing may differ accordingly.

The need for a shared sense of community can be satisfied by other dwelling types too. Another example is cooperative housing. Today's cooperative housing in Japan has evolved since the 1970s, and has been linked to the idea that such a housing system would enable future residents to participate in decision-making on both project and dwelling design, and would strengthen the sense of community among residents. In accordance with this assumption, some projects have provided various shared communal facilities and outdoor spaces such as communal gardens, playgrounds for children and day nurseries (Endo, 1995; Shinohara et al., 2002).

The pursuit of alternative living also intersects with the challenge for institutions and public bodies in developing residential space. Examples can be found among current service housing projects for the frail and elderly. Housing complexes with shared communal playrooms for children and daycare facilities have been developed and provided through the housing market too. However, taking into consideration that the most significant aspect of these alternative residential forms is the autonomy of residents, which may be assured by provision of private space 
and self-sufficiency as well as participation in management and maintenance of communal facilities, it seems that current market responses to varied housing needs will inevitably be unsatisfactory.

\section{Conclusions}

During the past two decades, along with the increasing number of employed women, a new role for women has emerged, which seems to contribute the expansion of women's life chances on the one hand, while increasing their load and responsibilities on the other. The introduction of advanced domestic management in technology and design did not reduce women's burden as was expected. The diversity of lifestyles has also expanded in accordance with the increase in divorced as well as never-married women. However, the physical environment as well as the housing system has not progressed concomitantly. Changing life patterns and social problems in Japan share many common features with those of women in western countries. At the same time, however, traditional value systems concerning home, family and gender relations have been leading to different responses to problems at both individual and social levels.

It seems that, despite of the rapid modernization of dwelling styles, housing and housing related services still lag behind many western countries where housing policies support households who have to procure and maintain decent dwelling through the housing allowance or/and social housing grant systems. Households facing similar conditions have fewer options in Japan. Consideration of housing conditions by household type suggests that women-headed households are facing severe problems. Both one-room accommodations and the n-LDK style dwelling are inadequate to the need for a sense of community and for mutual interrelations with others, of which women are more conscious.

The conventional view of women's roles and mothering norms seem still to have a great influence on the dwelling form as well as in living arrangements. Public support for the development of alternative living and dwelling types is limited and women face a deficiency in terms of realistic housing options corresponding to their needs. For instance, the institutional provision for lone mother families does not provide an ideal solution. Such housing has been reserved only for those who cannot afford to live in ordinary houses and it has thus been considered as an inferior substitute to real family housing. Institutional residences are also influenced by the present social value systems. Views seem to have been imposed through the legal frameworks as well as daily practices. The reality of institutional living seems to suggest that self-sufficient units with private facilities may be necessary to facilitate spontaneous participation in communal life among residents.

Currently, it is not only women who wish to make the pursuit of a professional career compatible with domestic life but also planners and politicians have become 


\section{Mieko Hinokidani}

more conscious about the physical environment of cities. Among other things, the sharp decline in the birth-rate has forced both central and local governments to adopt social measures to assist young and middle-aged women with double workloads. The increasing subsidies in the provision of a daycare centres for children as well as for the elderly are examples of such measures. Urban restructuring policies have also been expected to transform modern cities into more gender friendly spaces. Factors such as the integration of women into decision-making and the activities of housing focused protest groups may accelerate this process.

Furthermore, socio-demographic changes such as the rapid increase in the diversity of lifestyles, the transition of living units from family to individual, the rise in the need for care and increasing interests in environmental issues will stimulate the development of alternative dwelling models, other than ones that have been provided by the market. One such dwelling model may be shared housing, though it seems to be unstable and remains simply a social experiment at the moment.

More appropriate provision of housing and related services may depend to a great extent on the willingness to improve public policy measures. The development of alternative housing presents a new challenge for Japanese society: to reconcile the pursuit of privacy with sustainable community life and to enhance women's life chances. It seems that both women and men are conscious of the degradation of the quality of residential life and increasingly isolated dwelling practices. The tendency has been to consider that living arrangements as well as housing policy measures are key elements in solving the problems that the Japanese increasingly face in everyday life.

\section{References}

Cabinet Office, Government of Japan (1996) Koreisha kaigo (Elderly care) Gekkan Yoron Chosa (Monthly Opinion Survey Bulletin, Feb.), Tokyo: COGJ.

Cabinet Office, Government of Japan (ed.) (2001) Kokumin Seikatsu Hakusho, Kazoku no Kurashi to Kozo Kaikaku (White Paper on the National Lifestyle, Family Life and Structural Reforms), Tokyo: COGJ.

Cabinet Office, Government of Japan (ed.) (2003) Kokumin Seikatsu Hakusho, Defure to Seikatsu, Jyakunen Frita no Ima (White Paper on the National Lifestyle, Deflation and Human Life, Present Situation of Young People without Stable Employment), Tokyo: COGJ.

Cabinet Office, Government of Japan (ed.) (2005) Kokumin Seikatsu Hakusho, Kosodate Sedai no Ishiki to Seikatsu (White Paper on the Consciousness and Life among Young Family Generation), Tokyo: COGJ.

Endo, Y. (1995) Korekara no Shugo Jyutaku Tsukuri (Making Future Housing Estates), Tokyo: Shobun-sha.

Franck, K.A. and Ahrentzen, S. (ed.) (1989) New Households, New Housing, New York: Van Nostrand Reinhold. 
Fujita, M., Hinokidani, M. and Michihiro, S. (1997) A study on the women's needs for housing and services, Osaka Shiritsu Daigaku Seikatukagaku-bu Kiyo (Annual Report of Human Life Science), 44, Osaka: Osaka City University, pp. 63-76.

Gilroy, R. and Woods, R. (eds) (1994) Housing Women, London and New York: Routledge.

Hamaguchi, M. (1949) Nippon Jutaku no Hokensei (The Feudality of the Japanese House), Tokyo: Sagamishobo.

Hasegawa, S. and Hinokidani, M. (2002) Bosi seikatsu shien shisetsu no kukan keikaku to jyuseikatsu ni kansuru kosatsu (A study on spatial planning and residential life in the institutions providing support to women-headed one-person households), Osaka Shiritsu Daigaku Seikatsu Kagaku-bu Kiyo (Annual Report of Human Life Science), 49, Osaka: Osaka City University, pp. 33-47.

Hayashi, C. (1992) Boshi Ryo no Sengo-si (The History of Dormitories for Mothers and Children after the War), Tokyo: Domesu Shuppan.

Hayden, D. (1981) The Grand Domestic Revolution: A History of Feminist Design for American Homes, Neighbourhoods and Cities, Cambridge, MA: MIT Press.

Hayden, D. (1984) Redesigning the American Dream: The Future of Housing, Work and Family Life, New York: Norton.

Hinokidani, M. (1998) Gendai josei no ikuji shien housaku ni taisuru shikousei to kyoju niizu ni kansuru kenkyu (A study on the women's preferences for childcare support systems and needs for housing and services), Toshi Jytaku-gaku (Urban Housing Science), 23, Tokyo: Association of Urban Housing Science, pp. 23-8.

Hinokidani, M. (2004) Jyutaku to setai tono kankei kara mita seisaku kadai (Policy issues from the perspectives of housing and household relationships), Jutaku (Housing), 53, Tokyo: Japan Housing Association, pp. 41-6.

Hinokidani, M. and Fujita, M. (1998) Collective kyoju no niizu wo motsu josei no tokusei, gendai josei no kyoju niizu ni kansuru kenkyu, Sono 2 (A study on the women's needs for living, part 2, potential needs for collaborative way of living among women), Nihon Kenchiku-gakkai Kinki Shibu Kenkyu Hokoku-shu (Annual Report of the Architectural Institute of Japan, Kinki Branch), 21, Osaka: Japan Architectural Institute, Kinki Office, pp. 753-6.

Ishido, N. and Volunteer Group of Collective Housing (2000) Collective Housing Tadaima Funto Chu (Collective Housing, Now Struggling On), Kyoto: Gakugei Shuppansha.

Kim, J.K. and Omi, T. (1994) Gendai kazoku no bunsan kyoju no jittai to kyoju networks no keisei (The actual conditions of dispersed residence and the formation of residential networks of modern families), Nihon Kenchiku Gakkai Keikaku-kei Ronbun-shu (Journal of Architecture, Planning and Environmental Engineering), 456, Tokyo: Japan Architectural Institute, pp. 209-16.

Koyabe, I. (1997) Korekutibu Haujingu no Susume (Recommendations for Collective Housing), Tokyo: Maruzen.

Koyabe, I. (2005) Hanshin Awaji daishinsai fukko 10 nen kensho yori, atarashii sumaikata ni okeru torikumi, Hyogo fukko Collective Housing (Verification of public housing policy ten years after the Great Hanshin Awaji Earthquake, new orientations of living styles in Hyogo public collective housing), Toshi Jyutaku-gaku (Urban Housing Science), 49, Tokyo: Association of Urban Housing Science, pp. 54-65.

Kurosawa, T. (1968) Koshitsu-gun jukyo towa nanika (What is the compartment group dwelling?), Toshi Jutaku (Urban Housing), 5/1968, Tokyo: Kashimashuppan-kai. 


\section{Mieko Hinokidani}

Kurosawa, T. (1997) Koshitsu-gun Jukyo, Hokai Suru Kindai Kazoku to Kenchikuteki Kadai (Compartment Group Dwelling, the Collapse of Modern Families and the Architectural Response), Tokyo: Sumai no Toshokan Shuppan Kyoku.

Little, J. (1994) Gender, Planning and the Policy Process, Oxford: Pergamon.

McCamant, K. and Durrett, C. (1994) Cohousing: A Contemporary Approach to Housing Ourselves, Berkeley, CA: Ten Speed Press.

Matusbara, S. (2001) Sumai to Suteitasu Jutaku Kindaika no Nihon-teki Gyakusetsu (Housing and Status, the Japanese Paradox in Housing Modernization), Otsu: Kaiseisha Shuppan.

Meltzer, G. (2000) Cohousing: verifying the importance of community in the application of environmentalism, Journal of Architectural and Planning Research, 17(2), Locke Science Publishing Co., pp. 111-31.

Ministry of Health, Labour and Welfare (MHLW) (2003) Chingin Kozo Kihon Tokei Chosa (Basic Statistical Survey on the Wage Structure in Japan), <http://www.mhlw.go/jp>.

National Institute of Population and Social Security Research (2000) Dai Nikai Zenkoku Katei Doko Chosa Kekka no Gaiyo (Overviews of the Results of the Second Survey on Residential Life), <http://www.ipss.go/jp>.

National Institute of Population and Social Security Research (2003) Nihon no Setaisu no Shorai Suikei (Projection of the Number of Households in Japan), <http:/www.ipss. go/jp>.

Nishikawa, Y. (1998) Shakuya to Mochiya no Bungaku-shi 'Watashi' no Utsuwa no Monogatari (History of Japanese Literature on Rental Houses and Owner-Occupied Ones: A Story of the Containers of 'I'), Tokyo: Sanseido.

Nishikawa, Y. (2001) New town no jumin e, Nihon-gata kindai-kazoku to sumai no hensen (To residents of new towns, the history of Japanese modern families and housing), Jutaku Sogo Kenkyu Zaidan Kenkyu Nenpo (Housing Research Foundation Annual Report), 27, Tokyo: Maruzen, pp. 3-19.

Organization for Economic Co-operation and Development (1995) Women in the City, Housing, Services and the Urban Environment, Paris: OECD.

Organization for Economic Co-operation and Development (2004) Employment Outlook 2004, Paris: OECD.

Ota, H. (1969) Jutaku Kindai-shi (History of Modern Japanese Housing), Tokyo: Yuzankaku-shuppan.

Ottes, L., Poventud, E., van Schendelen, M. and Segond von Banchet, G. (eds) (1995) Gender and the Built Environment: Emancipation in Planning, Housing and Mobility in Europe, Assen: Van Gorcum.

Shinohara, S., Oohashi, S., Koizumi, M. and Research Group on Lifestyle (eds) (2002) Kawaru Kazoku to Kawaru Sumai, 'Jizai-Kazoku'no tameno Sumai-ron (The Changing Family and Changing Living, Housing Theory for the 'Flexible Family'), Tokyo: Shokokusha.

Shirahase, S. (2005) Shoshi Korei Shakai no Mienai Kakusa (Concealed Disparities in the Society of Declining Birth-Rates and an Ageing Population), Tokyo: Tokyo University Press.

Social Welfare Board of Aichi Prefecture (1984) Aichiken Shakai Fukushi Kyogikai: Aichiken ni okeru Boshi Ryo, Zairyo Setai no Seikatsu Jittai to Ishiki (Dormitory for Mothers and Children in Aichi Prefecture: The Actuality of Daily Life and Consciousness of Residents), Aichi: Aichiken Shakai Fukushi Kyogikai. 
Sumita, S. (ed.) (1983) Gendai-Jutaku no Chiho-sei (The Locality of Modern Housing in Japan), Tokyo: Keisoshobo.

Takada, M. (2002) Shoshi korei shakai ni okeru kyoju kukan no saihen (Remodelling of residential space in a society facing declining birth-rates and an ageing population), in M. Hirohara, N. Iwasaki and M. Takada (eds) Shoshi Korei Jidai no Toshi Jutaku (Urban Housing in the Era of Declining Birth-Rates and the Aging Society), Kyoto: Mineruva Shobo, pp. 270-92.

Takada, M., Fukao, S., Chikazumi, S., Takama, S., Manabe H., Iwamura, K., Ueda, M., Uchida, Y., Egi, G., Endo, T., Ota, H., Ochi, K., Otuski, T., Kawamura, S., Kitada, E., Kinoshita, Y., Kodama, Y., Sasaki, K., Shinohara, S., Sogabe, M., Tachibana, N., Tatsumi, K., Habraken, N.J., Horiba, H., Motokura, M., Moriyama, Y. and Yoshimura, T. (2005) Next 21 Sono Sekkei Supirittsu to Kyoju Jikken 10 Nen no Zenbo (Next 21: All about the Next 21 Project, its Design Concept and Living Experimentation for the Last Ten Years), Osaka: Osaka Gas Co.

Tokyo Metropolitan Government (2004) Tokyoto Jutaku Hakusho, Toshin Kyoju no Daini Maku (White Paper on Housing, the Second Stage of Urban Living in City Centres), Tokyo: Dept. of Housing, TMG.

Ueno, K. (1996) Co-housing no tenkai (Practices of co-housing) in K. Hayakawa, Y. Kishimoto and A. Suzuki (eds), Gendai Kyoju: Kazoku to Jukyo (Housing Policy: Family and Housing), Tokyo: Tokyo University Press, pp. 181-204.

United Nations (2005) The World's Women 2000: Trends and Statistics, New York: UN.

Van Vliet, Willem (ed.) (1988) Women, Housing and Community, Aldershot: Avebury.

Vestbro, Dick Urban (1997) Collective housing in Scandinavia: how feminism revised a modernist experiment, Journal of Architectural and Planning Research, 14(4), Locke Science Publishing Co., pp. 329-42.

Vestbro, Dick Urban (2000) From collective housing to cohousing: a summary of research, Journal of Architectural and Planning Research, 17(2), Locke Science Publishing Co., pp. 164-78.

Wakabayashi, Y., Kamiya, H., Kinoshita, R., Yui, Y. and Yano, K. (2002) Single Jyosei no Toshi Kukan (Urban Space of Single Women), Tokyo: Daimyodo.

Yamamoto, R. (1993) Saibo Toshi (Cell City) Inax Album 12, Tokyo: Inax.

Yazawa, S. (1996) Gender to toshi kyoju (Gender and urban living) in K. Hayakawa, Y. Kishimoto and A. Suzuki (eds) Gendai Kyoju: Kazoku to Jukyo (Housing Policy: Family and Housing), Tokyo: Tokyo University Press, pp. 83-107.

Yazawa, S., Kunihiro, Y. and Tendo, M. (2003) Toshi Kankyo to Kosodate, Shoshika, Jenda, Shichizunshippu (Urban Environment and Childcare, Declining Birth-Rate, Gender and Citizenship), Tokyo: Keisoshobo.

Yui. Y., Kamiya, H., Wakabayashi, Y. and Nakazawa, T. (2004) Hataraku Jyosei no Toshi Kukan (Urban Space of Working Women in Tokyo), Tokyo: Kokon Shoin. 


\title{
7 Social exclusion and homelessness
}

\author{
Masami Iwata
}

Flexible accumulation, as I shall tentatively call it, is marked by a direct confrontation with the rigidities of Fordism. It rests on flexibility with respect to labour processes, labour markets, products, and patterns of consumption. It is characterized by the emergence of entirely new sectors of production, new ways of providing financial services, new markets, and, above all, greatly intensified rates of commercial, technological, and organizational innovation. It has entrained rapid shifts in the patterning of uneven development, both between sectors and between geographical regions, giving rise, for example, to a vast surge in so-called service-sector employment as well as to entirely new industrial ensembles in hitherto undeveloped regions ... It has also entailed a new round of what I shall call 'time-space compression' in the capitalist world - the time horizons of both private and public decision-making have shrunk, while satellite communication and declining transport costs have made it increasingly possible to spread those decisions immediately over an ever wider and variegated space.

These enhanced powers of flexibility and mobility have allowed employers to exert stronger pressures of labour control on work-force in any case weakened by two savage bouts of deflation, that saw unemployment rise to unprecedented post-war levels in advanced capitalist countries (save, perhaps, Japan).

(Harvey, 1990: 147)

\section{Introduction}

In the 1980s, Japan avoided the huge socio-economic changes and flexible accommodation identified by Harvey which western countries experienced after the 1970s oil crisis. However, Japan finally faced up to change in the early 1990s, after the bursting of the bubble economy. Japanese labourers no longer enjoy stability under Japanese employment practices. Regular workers who have 
depended upon long-term employment and company welfare systems have been increasingly replaced by independent workers, i.e. non-regular workers who can develop their lives outside 'company society'. As a result, approximately 20 per cent of workers work on a non-regular basis according to the Labour Force Survey conducted in 2004. Total unemployment increased from 2.0 per cent in 1980 to 5.4 per cent in 2003. Unemployment of young males (aged between 15 and 29) has remained strikingly high at 8-9 per cent.

At the same time, the family system which has supported Japanese workers has also changed drastically. According to the National Census, the average number of people per household was 3.22 in 1980, but had dropped to 2.67 in 2000 (Statistics Bureau, 2003). Nuclear families with children have been increasingly replaced by single households and couple-only households. In the 2000 Census, single households and couple households accounted almost half of total households. In addition, the 2000 Census revealed an increase in unmarried people. In the age group between 30 and 34, 42.9 per cent of males and 26.6 per cent of females are unmarried. It also reported that the proportion of married men aged between 25 and 34 and the proportion of those with children are related to the level of annual income (Cabinet Office, 2005). In other words, the increase in numbers of nonregular workers with low incomes has led to declining birth-rates and shrinking family size. Increasing numbers of people are falling out of the family system at the same time as the family is shrinking - which undermines the family's capacity to provide support for its members.

It is in this context that new social problems have arisen in Japan. For instance, from the mid-1990s, many cities have experienced a shock increase in rough sleepers in parks and around train stations, and increases in unemployment and numbers of non-regular workers among young people. The new word, freeter, emerged in the Japanese language to describe part-time, non-regular workers under 34 . The word NEET (Not in Employment, Education or Training) was also exported from the UK to describe characteristics of growing numbers of unemployed youth. According to a Cabinet Office report (Cabinet Office, 2003), the number of freeter was 4.17 million in 2001. The number of NEET was estimated at 630,000 in the 2003 Labour Force Survey. Rates of high school dropouts are also linked to these phenomena. Domestic violence including child abuse and abuse of the elderly has also become more acute. These social problems have been discussed under the integrated term of social exclusion in Europe. However, the term is not frequently used in Japan. This chapter will discuss problems of street homelessness after 1990 in Japan in terms that have been used in social exclusion debates.

The concept of social exclusion came into focus along with 'inclusion policy', as they were advocated to replace equality strategies in European social democratic states, which were seen as no longer effective in a global market which is 'indifferent to social cohesion' (Gray, 2000: 21). At first, the term was used for those who lived on the margins of society without access to the social insurance 
system (often typically long-term unemployed youth). Now it has been expanded to include all types of social disadvantage. Percy-Smith states:

Social Exclusion has been defined in a number of different ways which may include all or some of the following elements; disadvantages in relation to certain norms of social, economic or political activity pertaining to individuals, households, spatial areas or population groups; the social, economic and institutional processes through which disadvantage comes about; and the outcomes or consequences for individuals, groups or communities.

As the concept of social exclusion has expanded, it has been interpreted in different ways to meet various purposes. Levitas classified three different discourses of social exclusion: a redistributionist discourse (RED) which focuses on inequalities of power and resources, a moral underclass discourse (MUD) which recognizes the nature of social exclusion as the morals and behaviour of excluded people, and a social integrationist discourse (SID) which emphasizes economic efficiency and social cohesion (Levitas, 1998; Stewart, 2000; Lister, 2000). In terms of differences between social exclusion and poverty, social exclusion is sometimes taken as being more or less synonymous with poverty (Percy-Smith, 2000: 4) or 'simply a euphemism for poverty' (Lister, 2000: 38). It has also been emphasized that social exclusion encourages a focus on social relations rather than distribution of material resources.

The term of social exclusion is thus contested and is often looked at critically. However, the following two points encapsulate the advantages of a social exclusion approach. First, social exclusion relates to the whole society system and thus we can focus who excludes who in the wider context, moving from individual to global levels. Second, social exclusion is a multi-dimensional and dynamic process with interconnections between various elements of past and present.

Homelessness often represents exclusion from society. Of course, there are several ways to define the state of homelessness. For instance, Bramley (1988: 26) classified the homeless into seven categories from 'people literally without a roof over their head' to 'individuals or groups living within existing households whose relationships and conditions are tolerable but where the individuals/groups concerned have a clear preference to live separately'. This wider sense of the definition has been challenged, but the majority of commentators agree that 'roofless', that is, those who regularly sleep rough, epitomizes homeless issues and its severest manifestations. In this regard, rough sleepers are not only extremely poor people, but are also those excluded from institutions and opportunities in society, which is often a more critical issue. In other words, they cannot ensure 'social-physical places to live' which are socially distributed to individuals and families according to their income, wealth, power, prestige, as well as other social 
characteristics (Wright, 1992; Iwata, 2003b). The fact that they do not have any 'social-physical place' within the community sharply reflects their exclusion from society. They are alienated in public space, as they are not 'proper' members of society, and they are often ejected from their temporary sleeping places. Wright describes contemporary homelessness in the United States where the moral underclass discourse (MUD) is dominant:

The destitute who sleep in local parks, shelters, or motels, or spend nights on a friend's living room floor, with no fixed residence of their own are people deemed out of place in the eyes of authority. And to be out of place means risking inspection by others, having one's identity defined by others as suspect as 'deviant,' or 'criminal,' or as just 'sick'. Homeless bodies, poor bodies, visible to passers-by, visible to the streets, are open to the public's gaze, to the gaze of authority.

The British government decided to prioritize the reduction of numbers of rough sleepers in the Social Exclusion Unit's Strategy of the 1990s. The unit publicized its first report on Rough Sleeping in 1998. The prime minister writes in the foreword of the report:

The sight of a rough sleeper bedding down for the night in a shop doorway or on a park bench is one of the most potent symbols of social exclusion in Britain today. It is a source of shame for all of us that there are still about 2,000 people put on the streets around England every night, and 10,000 sleep rough over the course of a year. There are good reasons for aiming to end rough sleeping. It is bad for those who do it, as they are intensely vulnerable to crime, drugs and alcohol, and at high risk of serious illness, and premature death ... And rough sleeping is bad for the rest of society. The presence of some rough sleepers on the streets will attract others - often young and vulnerable - to join them. Many people feel intimidated by rough sleepers, beggars and street drinkers, and rough sleeping can blight areas and damage business and tourism.

(Social Exclusion Unit, 1998: 1)

Rough sleeping itself is thus treated as a typical and explicit form of social exclusion in social space. However, this special form of exclusion should be understood as a complicated process of inclusion and exclusion within a framework of contemporary socio-economic change, rather than just simply a surface phenomenon of visible exclusion on the street. The term social exclusion enables a more dynamic analysis of the phenomenon. At the same time, potential institutional inclusions in terms of homelessness policies need to be considered. 
This chapter will discuss street homelessness in Tokyo by, first, illustrating homelessness processes and practices of homeless people on the street to reveal characteristics of inclusion and exclusion and related multi-dimensional factors, and secondly, by exploring potential inclusion through homeless policies.

\section{Routes into homelessness}

The number of people rough sleeping started increasing during the period of socio-economic upheaval of the mid-1990s in Japan. The categorization used is one of 'homeless' and is a narrower interpretation than ones in other countries and falls into only one category of Bramley's seven, as quoted above. People, literally, without a 'roof over their head' are the sole subject of homeless policies in Japan. Increasing numbers of rough sleepers in Japan have become a social problem, and hatred and criticism towards those who illegally occupy public space has developed, while there is also much sympathy in other quarters for those who can only sleep in public spaces. Regarding the growing prejudices against the homeless, news stories about youths throwing stones at rough sleepers or killing them have become more common place. In Japan, this has not been clearly discussed by using the term 'social exclusion', but has generated debate concerning those who are excluded from 'socio-physical space', which requires social responses.

The national government began counting of the size of the homeless population annually from 2000, and the national average is about 25,000. Some support groups strongly assert that the figures substantially underestimate real numbers. Additionally, many women and families of homeless people are often 'hidden homeless'. Moving homeless people to hostels (shelters or independent centres) has been recommended by local governments as a strategy to improve the selfdependency of homeless people. Nevertheless, in terms of the limited category of 'rough sleepers', the population has remained stable every year. In real terms this means that new homeless people have appeared on streets one after another, while others have moved off the streets into merely temporary shelters, thus maintaining the official figure, There are two contradictory perspectives on routes or processes into street homelessness in Japan. One argues that increases in unemployment, due to the bursting of the bubble economy in the 1990s, have exaggerated or extended the potential for more vulnerable individuals to become homeless. The other argues that homelessness is a particular issue for unskilled day labourers based in yoseba districts. The yoseba districts are generally characterized by massed flophouses and by open-air labour markets, where individuals compete for ephemeral employment in the construction and transportation industries. At the same time, they are also widely known as a place for poor people or 'dropouts' to find last-minute work and accommodation. 
This leads to the question, how did people end up on these streets, and through what kind of processes? This chapter will attempt to respond to this question with evidence gathered through a survey of homelessness conducted in the streets of Tokyo. Before going into the survey results, it is necessary to provide an overview of Japanese homelessness. Table 7.1 shows sex, age, education and marital histories of homeless people extracted from the nationwide homeless survey conducted by the Ministry of Health, Labour and Welfare in 2003 as well as city-level surveys. From the table you can see that street homelessness after the 1990s is characterized, first, by middle-aged men (average age of about 55). Not only does the number of homeless stay relatively stable year on year, but so do the average age (55) and gender (male) of the homeless. However, recent total unemployment rates (male) have increased among young people, and the rate for those in their 50s is slightly below the average. If it were true that increasing unemployment in a globalizing society has caused homelessness, young people should be more affected. Of course, it needs to be noted that the narrow definition of homelessness tends to exclude young or female homeless people who often disappear from the statistics by staying in institutions or friends' houses. Yet, it does show that the numbers of homeless people who have appeared on the street cannot be accounted for simply in terms of general unemployment, but is related more to the characteristic unemployment among middle aged males.

Secondly, homelessness in Japan is dominated by individuals with a specific educational and marital status (Table 7.1). Their educational level is low (completed compulsory education only) and many of them have never married. Indeed, it has been pointed out before that 'educational failure is strongly associated with the process of social exclusion' (Sparkes and Glennerster, 2000). Many Japanese homeless people received much poorer education than the average. They also have not formed families. In other words, insufficient human capital is implicated in the process of becoming homeless. The lack of financial capital of homeless people is arguably derived from negative human capital.

Table 7.1 also shows national average age, education, and marital status of males from the 2000 National Census as a point of reference. In comparison with the average, homeless people are a rather distinguishable group. As a matter of fact, these group characteristics have not changed since the early 1990s when numbers of homeless people started increasing. In this decade, middle-aged males with an absence of human capital have appeared to accumulate on the streets one after another.

In light of these broader data on the homeless we can begin to discuss street processes in relation to the result of an interview survey conducted by the author with 710 homeless people in the street in the Tokyo ward areas in 2000. Although various factors are complexly interconnected in the process leading to life on the street, processes of job loss and house loss will be focused on in the following. In order to understand the significance of the job loss process, two jobs in the life 
Table 7.1 Demographic characteristics of homelessness (\%)

\begin{tabular}{|c|c|c|c|c|c|}
\hline & $\begin{array}{l}\text { National } \\
\text { survey } \\
(N=2,163)\end{array}$ & $\begin{array}{l}\text { Tokyo } \\
\text { survey }^{b} \\
(N=710)\end{array}$ & $\begin{array}{l}\text { Osaka } \\
\text { surveyc } \\
(N=672)\end{array}$ & $\begin{array}{l}\text { Kawasaki } \\
\text { survey } \\
(N=841)\end{array}$ & $\begin{array}{l}\text { Population } \\
\text { census } \\
\text { (male) }^{b}\end{array}$ \\
\hline \multicolumn{6}{|l|}{ Sex } \\
\hline male & 95.2 & 97.7 & 97.0 & 99.3 & \\
\hline female & 4.8 & 2.1 & 3.0 & 0.7 & \\
\hline \multicolumn{6}{|l|}{ Age } \\
\hline 15-19 years old & 0.0 & & & & 7.4 \\
\hline $20-29$ & 0.6 & $0.6^{d}$ & & & 23.0 \\
\hline $30-39$ & 3.9 & 6.1 & $3.2^{\mathrm{e}}$ & $1.4^{e}$ & 16.8 \\
\hline $40-49$ & 14.7 & 19.6 & 17.1 & 13.1 & 17.7 \\
\hline $50-59$ & 45.4 & 47.9 & 45.0 & 49.7 & 15.9 \\
\hline $60-69$ & 30.8 & 22.9 & 30.8 & 33.7 & 11.7 \\
\hline 70 and over & 4.6 & 2.9 & 3.9 & 2.2 & 7.5 \\
\hline median age & 55.9 & 54.0 & 55.8 & 56.6 & 36.8 \\
\hline \multicolumn{6}{|l|}{ Education } \\
\hline $\begin{array}{l}\text { less than junior high } \\
\text { school graduate }\end{array}$ & & 2.7 & 1.7 & $75.0^{f}$ & 0.1 \\
\hline $\begin{array}{l}\text { junior high school } \\
\text { graduate }\end{array}$ & & 60.2 & 60.3 & & 25.1 \\
\hline $\begin{array}{l}\text { high school } \\
\text { graduate }\end{array}$ & & 28.8 & 32.2 & 20.1 & 47.8 \\
\hline $\begin{array}{l}\text { more than high } \\
\text { school graduate }\end{array}$ & & 8.4 & 5.4 & 2.6 & 23.1 \\
\hline \multicolumn{6}{|l|}{ Marital status } \\
\hline married & 53.4 & 5.9 & $69.7^{9}$ & 7.0 & 87.8 \\
\hline $\begin{array}{l}\text { divorced, widow/ } \\
\text { widower }\end{array}$ & & 41.2 & & 21.0 & 5.9 \\
\hline never married & 46.6 & 52.9 & 30.3 & 69.1 & 4.3 \\
\hline
\end{tabular}

Source: Ministry of Health, Labour and Welfare, Toshi Seikatsukenkyu-kai, Osaka City University.

Notes:

a Year of survey, 2003;

b Year of survey, 2000;

c Year of survey, 1999;

d includes all 15-19 year olds;

e includes all 15-39 year olds;

$\mathrm{f}$ includes junior-high graduates and junior-high non-graduates who did not graduate from high school;

$\mathrm{g}$ includes married, divorced and widowed. 
history of a homeless person, the main job (the job that he/she engaged in the longest time) and the most recent job, will be analysed in terms of employment type and employment status.

Table 7.2 shows that the respondents had various types of occupations in terms of their main job: 46.6 per cent were skilled workers including craftsmen, factory, transport and construction workers, 20.3 per cent were unskilled labourers and 19.5 per cent were engaged in sales or service industries, including cooks, waiters, shop clerks, newspaper agents, cleaners, security service workers. Managers, officials and clerical workers accounted for 10 per cent of the sample. In relation to employment status, 55.9 per cent had regular employment, while 21.8 per cent

Table 7.2 Occupations and employment status prior to homelessness (\%)

\begin{tabular}{lcc}
\hline & $\begin{array}{l}\text { In the time of main } \\
\text { job }\end{array}$ & $\begin{array}{l}\text { Just before becoming } \\
\text { homeless }\end{array}$ \\
\hline Type of occupation & & 1.9 \\
managers/professional & 4.1 & 2.5 \\
clerical & 5.9 & 0.6 \\
agricultural & 1.7 & 28.9 \\
skilled worker & 46.6 & 13.0 \\
sales, service worker & 19.5 & 39.9 \\
unskilled labourer & 20.3 & 0.5 \\
others & 0.6 & 12.7 \\
no occupation & 0.1 & 0.0 \\
unknown & 1.1 & \\
Type of status (1) & & 1.1 \\
employer, manager & 1.7 & 3.5 \\
self-employed & 5.5 & 0.8 \\
employing others & 0.8 & 28.1 \\
regular employee & 55.9 & 16.2 \\
temporary employee & 11.8 & 44.2 \\
day labourer & 21.3 & 0.9 \\
others & 0.7 & 5.2 \\
unknown & 2.3 & \\
Type of status (2) & 63.9 & \\
stable & 33.1 & \\
unstable & & \\
\hline
\end{tabular}

Source: Toshi Seikatsukenkyu-kai. 
were day labourers. In the period just before they came onto the street, 28.9 per cent were still skilled workers and 13.0 per cent were service workers. However, 44.2 per cent were day labourers and 7.9 per cent of them were unemployed. About 30 per cent were still regular workers or self-employed. Using employment status criteria, job status can be divided into two categories: stable job and unstable job. The stable jobs include employers, managers, the self-employed, and regular employees. These are considered to be better jobs in Japanese society. In contrast, the unstable jobs include temporary employees and day labourers, which are considered lower rank jobs. From this dichotomy of stable and unstable, 63.9 per cent had relatively stable work experiences when they were in their main job, which reveals that many of them used to be more included in society through their work. Of course, taking their educational background into account, they were not stable workers in large companies but many of them worked in small and medium-sized factories and shops. Additionally, the fact that 73.6 per cent were covered under the social insurance system at the time of their main job shows that many homeless people were also included in social institutions and covered by social insurance in the past. However, Table 7.2 suggests that, just before they came onto street, their inclusion-through-work and their socially included status became fragile.

The pattern of former accommodation of homeless people is very specific. The ratio of owned housing and private rented housing is relatively low. The proportion of job-associated accommodation (e.g. company dormitories) and temporary accommodation (such as inns and hostels) is high and was so even at the time a main job was held. During their main job 42 per cent lived in jobassociated accommodation and the proportion was 37.6 per cent just before they appeared on the street (Table 7.3). Many homeless people who had stable work experiences in terms of employment status and social insurance status had lived not in general housing but in job-associated housing. Types of accommodation can also divided into three categories: general accommodation including owned housing and rented housing, job-associated accommodation including company housing, dormitory and sleep-in facilities, and others, including hostels, inns, hospitals, prisons and so on. During the time of holding a main job only 47.5 per cent lived in general accommodation. By contrast, the rate of homeless people who lived in job-associated accommodation was 42.0 per cent at the time of holding a main job and was 37.6 per cent just before they moved to the street. Taking account of the many 'never-married' homeless, it seems that many had lived outside of family units and seemed to have only been included in Japanese society through their work. Additionally, 28.5 per cent of the homeless already lived outside of secure housing before rough sleeping.

Through the characteristics of past jobs and housing, we can begin to categorize processes into homelessness. Of course the process of those who had stable jobs and general housing is different from the process of those who hopped between 
Table 7.3 Type of housing prior to homelessness

\begin{tabular}{lcc}
\hline & $\begin{array}{l}\text { In the time of } \\
\text { main job }\end{array}$ & $\begin{array}{l}\text { Just before } \\
\text { becoming } \\
\text { homeless }\end{array}$ \\
\hline $\begin{array}{l}\text { Type of housing (1) } \\
\text { owned house }\end{array}$ & 16.2 & 8.5 \\
rented house & 29.3 & 23.4 \\
Public rented house & 2.4 & 1.0 \\
company house/worker's & 42.0 & 37.6 \\
dorm. & 6.6 & 15.5 \\
hostel (flophouse) & 1.4 & 7.3 \\
inn/hotel & 1.8 & 5.7 \\
others & 0.3 & 1.1 \\
unknown & & 32.9 \\
Type of housing (2) & 47.9 & 37.6 \\
general accommodation & 42.0 & 28.5 \\
job-associated & & \\
accommodation & 9.8 & \\
others & &
\end{tabular}

Source: Toshi Seikatsukenkyu-kai.

unstable jobs and different types of housing. The former process involves the movement from inclusion in society to becoming excluded, while the latter involves people who were not sufficiently included in society from the beginning. For those who lived in job-associated accommodation, the process of becoming homeless may be understood in the context of failed integration into society through work. These classes of employment status and housing are analysed following a cluster method, resulting in the following three different types:

Type 1. Fully included: stable main job and lived in general housing just before becoming street homeless.

Type 2. Included through work: stable main job and lived in job-associated accommodation just before moving onto the streets.

Type 3. Long-term excluded: unstable main job and housing.

Except for a few cases that cannot be classified into these categories, among our sample the proportion of Type 1 accounted for 35 per cent, Type 228.9 per cent and Type 335.3 per cent. Type 2 cases were not expected to be so significant before the survey was conducted as it was thought that they were included in society as regular workers. However, as symbolized in their housing status, their 
Table 7.4 Demographic characteristics of homelessness by homeless type (\%)

\begin{tabular}{llll}
\multicolumn{2}{c}{ Types of homelessness } & & \\
\hline Fully & Included & Long \\
included & Through \\
work & excluded & \\
& & & \\
& & &
\end{tabular}

\begin{tabular}{|c|c|c|c|c|}
\hline \multicolumn{5}{|l|}{ Age } \\
\hline $20-29$ & 0.4 & 0.0 & 1.3 & 0.6 \\
\hline $30-39$ & 5.1 & 10.9 & 3.8 & 6.4 \\
\hline $40-49$ & 19.9 & 20.9 & 18.8 & 19.8 \\
\hline $50-59$ & 52.1 & 42.8 & 47.3 & 47.6 \\
\hline 60 and over & 22.5 & 25.4 & 28.9 & 25.6 \\
\hline \multicolumn{5}{|l|}{ Marital status } \\
\hline $\begin{array}{l}\text { married (including } \\
\text { separated, } \\
\text { divorced, } \\
\text { widowed) }\end{array}$ & 56.8 & 47.5 & 36.7 & 47.1 \\
\hline never married & 43.2 & 52.5 & 63.3 & 52.9 \\
\hline \multicolumn{5}{|l|}{ Education } \\
\hline $\begin{array}{l}\text { at least junior high } \\
\text { school graduate }\end{array}$ & 52.3 & 62.2 & 74.9 & 63.2 \\
\hline $\begin{array}{l}\text { higher than junior } \\
\text { high school }\end{array}$ & 47.7 & 37.8 & 24.7 & 36.7 \\
\hline \multicolumn{5}{|l|}{$\begin{array}{l}\text { Period of rough } \\
\text { sleeping }\end{array}$} \\
\hline less than 1 year & 39.7 & 27.3 & 29.2 & 33.0 \\
\hline $1-5$ years & 41.9 & 42.9 & 40.0 & 41.5 \\
\hline more than 5 years & 18.4 & 29.8 & 30.8 & 25.6 \\
\hline
\end{tabular}

Source: Toshi Seikatsukenkyu-kai.

link to society was only through employment and thus they became homeless when they lost this link.

As stated earlier, homelessness is generally characterized by never-married middle-aged males with a poor education. However, these characteristics considerably differ in each of our types (see Table 7.4). In the case of the over-60 age group, the proportion of basic compulsory education only and never-married is high in the 'long-term excluded' group (Type 3), the 'included through work' group (Type 2) is the next, and the 'fully included' (Type 1) is the lowest in these terms. The never-married rate of 'long-term excluded' (Type 3) is 63.3 per cent, the 'included through work' (Type 2) is 52.5 per cent, and the 'fully included' 
Table 7.5 Reported period of rough sleeping of shelter residents and street homeless in Tokyo (\%)

\begin{tabular}{llc}
\hline & $\begin{array}{l}\text { Shelter } \\
\text { (Otaryo) }\end{array}$ & Tokyo survey \\
\hline $\begin{array}{l}\text { Period of rough sleeping } \\
\text { less than 3 months }\end{array}$ & 42.3 & 12.3 \\
3-6 months & 13.9 & 7.3 \\
6 months-1 year & 10.6 & 14.1 \\
1-3 years & 15.0 & 27.2 \\
more than 3 years & 18.1 & 39.0 \\
Style of street living & & \\
$\quad$ fixed place with a tent or & 20.9 & 41.8 \\
others & & \\
wandering & 60.2 & 54.5 \\
other & 18.8 & 3.7 \\
\hline
\end{tabular}

Source: Toshi Seikatsukenkyu-kai and Otaryo Riousha Chosa.

(Type 1) is 43.2 per cent. Of the 'long-term excluded' (Type 3) 74.9 per cent have a basic compulsory education only, but the rate is relatively lower in the 'included through work' group (Type 2, 62.5 per cent) and the 'fully included' (Type 1, 52.3 per cent).

In this regard, inclusion and exclusion processes for these three types can be illustrated as follows. First, the 'fully included' group (Type 1) probably used to be constituted of various types of regular workers in small and medium-sized companies, individual proprietors or small-scale business owners. More than half of them have relatively good educational backgrounds and used to live in regular housing with their families. They were sufficiently included in social institutions, that is, the social insurance system. The factors that have excluded them from society have been unemployment and bankruptcy under increasingly globalized socio-economic conditions. Their age (average 55) proved very disadvantageous in the changing labour market. However, it is not the only reason why they ended up on the streets. Unemployment has a number of associated problems, for example, family breakdown due to separation or divorce, disease, multiple debts, rent arrears, etc. which helped them onto the street. Multiple debts, especially, appear as a major factor in the disengagement of the fully included category from society. A survey of shelter users in Tokyo revealed that 30 per cent had outstanding debts. It is interesting to note that the group with experience of debts used to be regular workers in administration, management and sales services, had relatively higher educational backgrounds and many of them were married (Tokubetuku-Jinji Kosei Jimu-Kumiai, 2003) 
In contrast to the 'fully included' category (Type 1), the process of becoming homeless for the 'long-term excluded' group (Type 3) is relatively simple, as they were not fully included in society in the first place. Many of them had poor educational backgrounds and had worked as unskilled day labourers based in cheap hotel lodgings and yoseba until they were nearly 60. Work in the construction industry has continued to shrink, as it has been the largest faltering industry after the 1990s. Factors of age and economic downturn thus fostered unemployment and they had no choice but long-term rough sleeping. Typically yoseba-based day labourers became the first group to become homeless. However, rough sleeping represented the vulnerability of day labourers in their daily life even during the rapid economic growth era. 'One day a day labourer could stay in a hotel because he managed to obtain a job, but the next day, he might sleep in a park or riverbank near yoseba' (Iwata, 2000). The condition was exacerbated into more regular rough sleeping after the 1990s. Many lost housing simply because they lost their job.

Many of the 'included through work group' (Type 2) were committed skilled or semi-skilled regular workers, but they were only able to connect to society through their work. Many never married or had separated from their families due to divorce, and lived in factory dormitories, company housing and accommodation provided by entertainment industries in cities. Unemployment led to the immediate loss of housing in the case of those in job-associated accommodation. After using up their savings in inns, many of them appeared on the streets. Because they are old and their skills and qualities are no longer required in today's society, they struggle to find another job.

In the background of Japanese street homelessness is the radical socio-economic change brought about by the growing impact of global laissez-faire relations (Gray, 2000). At the same time, unemployment of yoseba workers is only a part of the problem. Processes into street homelessness are complex. Some people were fully included in society and others were included only through working and were not able to ensure continued employment. However, lack of human capital can be seen as the common cause in the exclusion processes.

\section{Policy responses to homeless problems: social assistance and homelessness}

Generally, homeless policies and measures aim to provide income support and social services, such as medical services, in cases where poverty and deprivation are focused. In the case of loss of housing, the need is the provision of houses. In context of increasing social exclusion, integration into society through work, especially through paid work, is often emphasized. Until the establishment of the Homeless Independent Living Act in 2002, the Living Standard Protection Act (Seikatsu Hogo Ho) proclaimed in 1950 mediated social assistance for those with housing problems in Japan. 
Japanese social assistance sets a social entitlement to a minimum standard of living for all Japanese people whose income is below the defined minimum standard. The state, using local government welfare offices, has a duty to provide low-income households with a combination of eight different types of aid on a mainly cash basis: living aid, housing aid, educational aid, medical aid, maternity aid, funeral aid, vocational aid and care aid, according to their circumstances. Since it is a general relief measure provided without any moral judgement, it does not legally exclude any individual or family, and does not therefore create particular welfare sub-groups such as older people or single parents. Thus those who lose their homes or who live in inadequate houses have an equal entitlement under this legislation as long as their living conditions are confirmed as being 'poor'. In the case of non-fixed abodes, the government's guidance in respect of this Act stresses that local government welfare offices have to offer assistance to homeless people whenever they find these people within their jurisdiction and they are able to confirm their impoverished state.

There are three major barriers to accessing Seikatsu Hogo Ho for homeless people in Japan, not including the exclusion of non-Japanese nationals (Iwata, 2003a). First, this general relief system requires people to demonstrate that, even though they have fully used their assets and various 'abilities', they are still in a situation of poverty. Although this legislation covers all Japanese living under the poverty line, this requirement plays a role in limiting social assistance to the poor, such as the old, handicapped and sick. Therefore, it rarely applies to working age people, especially men. In reality, if a 55-year-old homeless male capable of work visits a welfare office to claim something from the system they will probably find that these rights do not apply to him. This situation regarding social assistance may be seen in many countries to a certain extent. Handler states that the main role of welfare policy is the preservation of the labour market and that the work requirement is the most important and enduring principle of welfare policy (1992: $35)$.

Second, even if single people without a fixed abode can qualify for this assistance, they have to be accommodated in hogo shisetsu institutions where they are given an aid package in kind, initially. Similarly, many homeless women and mothers are referred to mother and children's homes or women's homes. This 'indoor relief principle' for the homeless is not described in the Act itself, but in both central and local government notifications. Of course, this institutional provision is limited to the short term as a halfway house. In addition, it must be pointed out that this special in-kind assistance can only be provided in some major cities such as Tokyo and Osaka.

Another reason for keeping this 'indoor relief principle' is that many social workers in local welfare offices are reluctant to find rented housing for homeless people, as it is time-consuming for them. Some welfare offices are not inclined to pay deposits for the homelessness from public funds. In Japan, a guarantee 
and deposit are necessary to rent private houses, and landlords do not tend to rent houses to former homeless people. Japan does not have housing allowance which can be paid directly to landlords, except housing aid stipulated in the Seikatsu Hogo Ho, so few landlords seek stable rent income from this form of social assistance. Meanwhile, social workers from local welfare offices have had experiences where, after finding houses for homeless people and handing over deposit and rent for the first month, the homeless individual disappears with the money. Thus, the housing aid of the Seikatsu Hogo Ho is used for rent and moving cost of the poor who have houses but is rarely used for new housing for the homeless.

Third, Seikatsu Hogo Ho is a national law in Japan, but local governments put it into practice and bear 25 per cent of cost. Therefore, local governments do not tend to welcome the expansion of Seikatsu Hogo Ho recipients. In addition to this, it is hard for local government welfare officers to apply this Act if there is any doubt that homeless people are local residents. They may come under harsh criticism from taxpayers if they help homeless people whom the local government cannot be sure even reside in their communities. Local government offices are used to providing services for 'legitimate' citizens in their areas. They are generally afraid of any concentration of homeless people in their areas because of their 'good provision' and fear being blamed for unsettling the everyday life of other citizens. Although local government welfare offices have duties to help all poor people within their jurisdictions by law, welfare offices have thus been reluctant to help people without a fixed abode. There is, therefore, a gap between the Act and its implementation mediated by local government processes.

As a result, Seikatsu Hogo Ho is applied only to those who are over the age of 65 , those who have severe disease or handicap, women or single mothers, because they 'can't work'. It is easy to imagine that these limits on social assistance are factors influencing the three typical exclusion processes of homeless people discussed earlier.

As Seikatsu Hogo Ho social assistance has excluded the majority of the street homeless, major cities with large homeless populations have needed to respond to the homeless outside of institutional legislation. In the mid-1990s, some cities started to install 'homeless measures'. According to local governments, these measures were 'humanitarian assistance' in order to relieve the misery of the street homeless who were excluded from public assistance. However, it was obvious that another purpose of the measure was to manage the occupation of public spaces by rough sleepers and to avoid conflicts between the homeless and ordinary citizens. The measures are mainly practised in the form of the following two programmes. One is the 'outside-law programme', which provides food, clothes, medical treatment, transportation fees and lodging costs via welfare offices. This has not been considered a very positive response but it has been implemented on 'humanitarian grounds' to prevent homeless people from dying in some cases. The range of the provision under this programme is diverse depending upon local 
welfare offices. Generous providers make special budgets for this programme, while less generous ones provide only leftovers from the public stores maintained in case of natural disasters (earthquake or otherwise).

The second is the 'special programmes for homelessness', which derive from the special programmes set up in the yoseba districts in Tokyo and Osaka in the 1960s. As riots by day labourers happened several times in that decade, Tokyo and Osaka governments launched special programmes involving the provision of special job centres, day centres, welfare and health services, and public housing for families falling outside of Seikatsu Hogo Ho. When the oil crisis struck Japan in the 1970s, Tokyo and Osaka reinforced their welfare programmes including the provision of winter shelters for rough sleepers in these districts. In the mid1990s, Tokyo and Osaka governments decided to extend yoseba programmes to a wider range of rough sleepers, with special emphasis on the provision of winter shelters.

Based on the experiences of Tokyo and Osaka, in 1999, the central government launched the Independent Living (Jiritsu Shien) policy which provided special hostels with vocational services and other necessities for those who expected to return to the labour market within approximately three months (MHW, 2000). It also formalized the definition of the term 'homeless people' as those who have no fixed abode and who sleep in the streets, parks, railway stations and other places. In 2002 the national government authorized a new policy, the Homeless Act (Jiritsu Shien Ho), as a 10-year provisional legislation and put funds aside. The Homeless Act is to be applied prior to social assistance, aiming first to promote inclusion through paid work. However, when application of the system is difficult, social assistance may be provided as a last resort if homeless people can articulate the conditions of their unemployed situation.

\section{Inclusion-through-work or inclusion-through-housing}

Many social policies focused on street homelessness assert that social inclusion should be achieved through paid work. 'Labour market participation has become the panacea for an inclusive society' (Kennett, 1999: 53). Of course, as described above, there are a variety of methods of inclusion. For example, inclusion can be achieved by being housed. In some cases supplementary income is provided to enhance the inclusion process. Some national policies follow a step-by-step approach to help individuals re-enter housing or return to the labour market, while other countries take the housing-first method, aiming at establishing regular housing in communities and in regular work places.

Japanese policies towards street homelessness after the 1990s are centred upon the Independent Living Policy through work, as I have discussed. The term, 'independent living' appears key in Japanese social policies after the 1990s. Even though the term 'social inclusion' is not used, the aims of policies are to convert 
the excluded into independent citizens without depending on the welfare system. This is thought to be achieved through joint elements of employment policies and welfare services. In this regard, it is similar to inclusion policies in Europe. Of course, the term in Europe includes not only independence through work but also independent life in the community as well as individual contributions to the community through various social activities. However, the goals have been narrowed down recently, and only independence and social participation through work are emphasized. The Independent Living Act for the homeless was enacted as a programme to transform the homeless into independent workers.

The central part of the Homeless Independent Living Policy is the provision of special hostel accommodation called independent living centres, where vocational services are offered. If welfare offices decide that a street homeless person can return to the labour market within three months, they are permitted to stay in the centre and receive job placement services as well as food, a bed and daily necessities. The centres also provide social services to prepare the return to the community and to help find housing. Those who cannot find a job within three months or those who are not judged as capable of work immediately are expected to be covered by different forms of public services including social assistance.

Within this policy framework specific programmes and execution levels are diverse, depending on financial situations and the number of homeless people in each city. The pattern of policy execution in Tokyo will be discussed as an example of Independent Living Policy. From Tokyo's experiences, the policy approach of inclusion-through-work can be considered from an inclusion perspective. Of course, it is also possible to verify effects of this policy as Tokyo has proactively promoted an Independent Living Policy through work.

Figure 7.1 shows an overview of the programmes and records of execution in Tokyo. The number of street homeless in the Tokyo ward area was reported at about 5,500 according to the seasonal survey conducted every six months (summer and winter). Among the street homeless the old and handicapped that the welfare office judge as incapable of work receive social assistance. In many cases, emergency shelter is provided first and then income provision for rented housing. For those capable of work emergency shelter can be provided for one month in order to assess whether independence through work is possible. Shelters are available around the clock and homeless people can receive food, a bed and other daily necessities as well as a counselling service. Shelters do not provide cash, such as the living aid of Seikatsu Hogo Ho, but only daily necessities as needed. It also needs to be pointed out that the standards of benefit do not always satisfy the national minimum stipulated in the Seikatsu Hogo Ho. If individuals are assessed as capable of independence through work, they move on to independent support centres. They receive job-search counselling, bed and board and other daily necessities for two months in these centres. If they can find a job, they are encouraged to stay on at the centres until they can save 
enough money, by working, for a deposit, rent and daily living costs for the first month in a new home.

In July 2005, 10,778 people were accommodated in five shelters in Tokyo (see Figure 7.1). Of these, 42.4 per cent $(4,565)$ moved on to independent support centres. In the judgement of the welfare offices, the remaining individuals were expected to receive social assistance, but in fact many of them reappeared on streets. Almost half of independent support centre residents, 2,711 people, achieved independence through work. Most jobs are service jobs, such as cleaners, security guards, waiters, etc, which require few skills. Moreover, the centres encourage people to take regular jobs, but many jobs are unstable in reality. The centres also encourage individuals to seek non-job-associated accommodation and regular rented housing as a rule. However half of them did not move to rented housing but to job-associated accommodation instead. The independent support centres

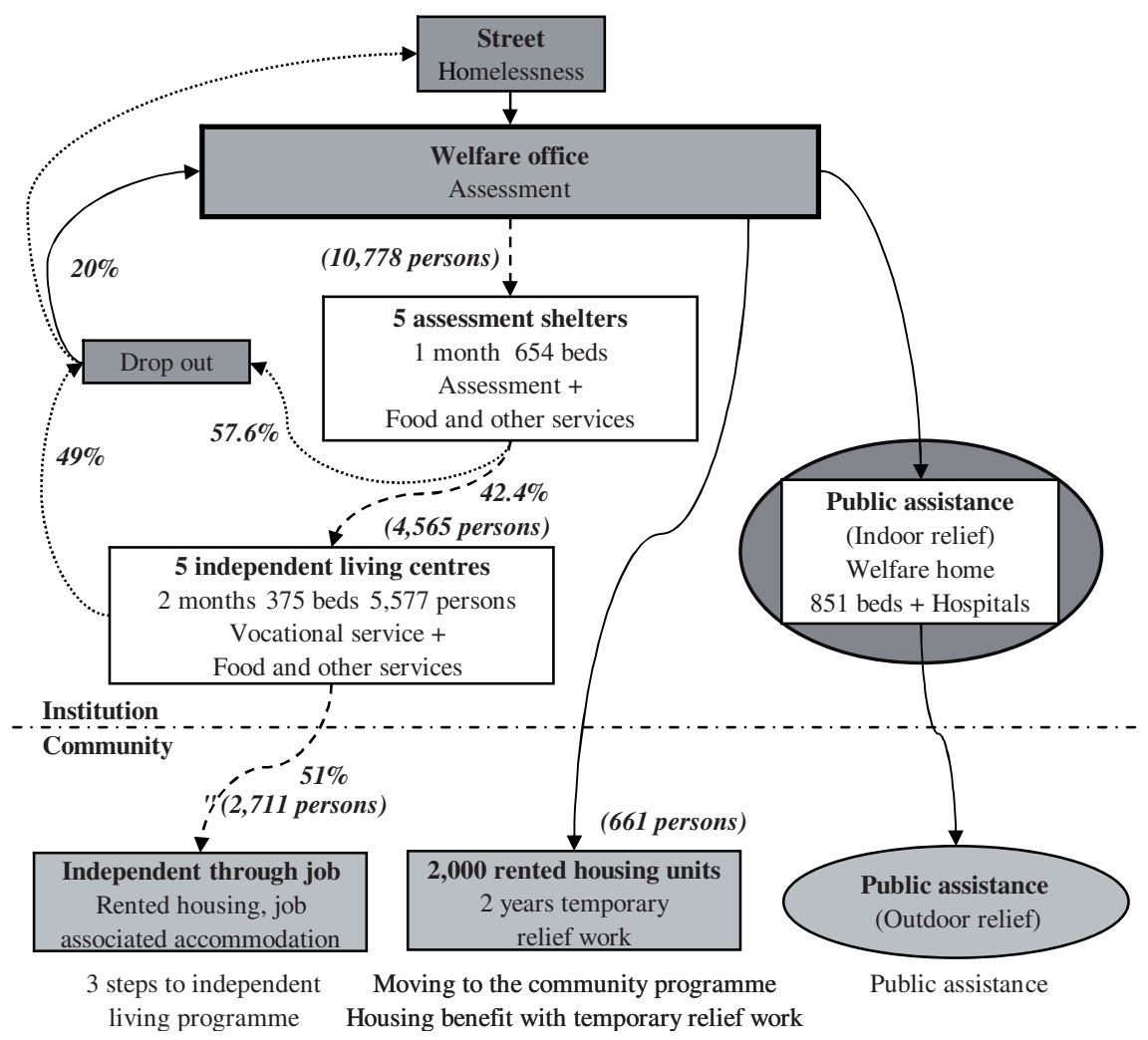

7.1 Welfare programmes for the homeless and numbers of users in Tokyo Note: (- persons) are culminative number of actual movers from shelters and centres from the date of each shelter's and centre's opening to July 2005. 
provide only two months of support, thus job-associated accommodation which offers a job and housing at the same time is popular. As a result, many people end up on the street again after losing work. Those who cannot find a job have three options: to apply for social assistance from the welfare office again, to stay in a shelter again or to return to the street. A recent survey of those who had returned to street living from the independence support centres reported that some experienced discrimination and severer conditions at work because they were from the centres. Many quit or ran away from company accommodation (Kitagawa, 2005). Many of those who were not able to find a job during their stay in the centres claimed that their age and address in the centre hampered job seeking, even though they tried many job interviews. They said they gave up looking for jobs through the centres.

The homeless covered by the Independent Living Policy are mainly the fully included type and experience a relatively shorter rough sleeping period. It also includes those who do not have experience of rough sleeping. Comparing the results of the Tokyo survey discussed earlier and shelter users (Table 7.5), the latter have obviously shorter rough sleeping periods. Few shelter users have settled in tents or cardboard-box houses. It is interesting that the inclusion policy through work covers those who are in a relatively 'better condition' in spite of its original goal. This is also observable in the European situation. Handler states that inclusion policy through work does not cover the actual excluded but rather those just above or just below the deprivation threshold (Handler, 2004: 207). He also observes:

However, the workless and the socially excluded are a diverse group, some more employable and trainable than others, some with fewer barriers than others, and it is the most vulnerable who run the greatest risks. Programmes of inclusion based on contract necessarily exclude those who cannot negotiate the entry points and conditions of participation. Workfare programmes are evaluated on the positive outcomes, and thus, there are pressures to cream. Programmes that target the most vulnerable will, inevitably, have higher failure rate.

(Handler, 2004: 199-200)

Long-term rough sleepers are settled in parks and hardly ever participate in the Independent Living Policy programmes. They generally do not believe that shelters and centres can offer immediate jobs. They are also aware that staying in a room with other homeless people generates frequent troubles. They prefer to live on the streets, depending upon an informal economy, such as rag picking. Since the number of homeless on the street has not decreased, taxpayers have started making more complaints about them. Thus, it can be said that the goal of the Independent Living Act of inclusion-through-work has not achieved its goal 
to include the most excluded street homeless people. In light of this failure, the Tokyo Metropolitan Government added a new policy in 2004, which is different from the Independent Living Policy. The new policy, named the 'Moving to Community Policy', aims at the inclusion of the homeless, not through work but through rehousing.

The objective of the Moving to Community Policy is undoubtedly the clearance of homeless people who settle in large parks. Nevertheless, since the new policy clearly aims at clearance of all homeless people from public spaces it, unlike the Independent Living Policy, avoids selectivity by employability and does not seek to accommodate the homeless in shelters. The new policy seeks more direct and immediate means for the homeless to return to the community by providing inexpensive rented housing (3,000 yen/month (£15 approx)) to all applicants. The Tokyo Metropolitan Government rents accommodation and sublets it to the applicants. Six-month temporary jobs (e.g. public work, cleaning parks, etc.) and comprehensive living support provided by non-profit organizations are added to the package of support. Although a housing allowance system is not available in Japan, the policy might be considered as a sort of housing allowance for the homeless. When the policy was first recommended, some members of homeless support groups came out against it because the policy aimed primarily at sweeping out the homeless from parks. However, many homeless people and some other support groups welcomed the programme because individuals would not have to be assessed by welfare offices or have to stay in shelters. As a result, 661 people moved to rented housing from four large parks in Tokyo from summer 2004 to spring 2005. Only one person declined. It initially appears that the remaining homeless resettled within the community.

The experiences of Tokyo illustrate some of the inadequacies of the "through work' policy, when we consider it as an inclusion policy. First, the low success rate of independence through work is not a surprise considering lack of human capital of the homeless, that is, age, lack of skills and poor educational background. For many, seeking work is futile. Public policies do not expand employment itself but just encourage inefficient practices. In other words, despite enhancement of vocational services, public policy cannot directly ensure stable employment for the homeless. It is true that the Independent Living Policy develops new services by connecting employment and welfare and expands ways for the homeless to return to the labour market, but it still has fundamental contradictions.

Second, the existence of Type 2 homelessness emphasizes that work is central for many in determining inclusion, which leads to greater vulnerability to exclusion. The jobs of these individuals were not marginal. Although they were regular workers, they easily became homeless. Thus, it can be said that the inclusion policy aiming at transforming them into independent workers just reproduces more precarious people like Type 2 homeless. As many scholars have pointed out, the inclusion policy through paid work only sees participation in the 
labour market as a solution by ignoring various complexities in the processes of becoming homeless (Kennett, 1999; Lister, 2000; Handler, 2004). The existence of Type 2 homeless people in the Tokyo survey suggests that the independent worker cannot be equated with full inclusion in society.

Third, the Independent Living Policy basically selects homeless people based on employability. Thus, the homeless are exposed to many other risks or aspects of exclusion in places like the welfare office, shelters and independent living centres. Moreover, those who are excluded from the policy are stigmatized as drop-outs. The most vulnerable people thus end up becoming even more vulnerable.

Fourth, the policy mechanism tends to attract those who recently came onto the streets or do not have experience of rough sleeping because of the steps of selection by employability. Clearly, welfare offices and social workers in the centres have a tendency to prioritize those who appear to be able to find work quickly. However, those most excluded, who illegally occupy public spaces and end up in most conflict with ordinary citizens, are the ones with the most need and least access to the policy.

These contradictions of the inclusion-through-work policy have fostered the establishment of the new policy of inclusion-through-housing. The inclusionthrough-housing policy is popular because it does not follow the steps from shelter to centre to work, set up by the inclusion-through-work policies. The policy does not tend to select or exclude people by assessment of employability. People do not wish to receive training based on the programme in shelters or centres, but wish to return to society first. Yasue reports that those who have returned to the community through the inclusion-through-housing policy experience substantial pleasure from improved accessibility to social services and in exercising normal citizenship rights (2005).

Of course this popular inclusion-through-housing policy has several significant problems. For example, the inclusion-through-housing policy offers only sixmonth temporary jobs and does not offer any income provision. Those who moved to rented housing thanks to the policy are expected to cover living expenses, except rent, from income made in the informal economy, which often involves the same type of work they used to engage in on the streets. In fact, it has been reported that some of the participants in the programme do not have enough money for food (Toda, 2005). Essentially, this policy has weaker vocational services than the Independent Living Policy does. The Tokyo Metropolitan Government commissions support groups to visit members for individual counselling. Users live across Tokyo's 23 wards and the commission cannot ensure a sufficient number of visitors. The service has been criticized as it has failed to play its expected role (Toda, 2005). Furthermore, it depends on the whim of the Tokyo Metropolitan Government whether users can continue to live in the same houses with low rent after two years. Since there is no clear housing allowance system in Japan, it also seems difficult to achieve the goal of the inclusion-through-housing. 


\section{Conclusion}

Japan's huge socio-economic transformations have enlarged inequalities and undermined the stability of the middle class, yet not all people have become vulnerable to homelessness. From the investigation of processes into street homeless people in Tokyo, it appears that those who hold human capital and are included in society in various ways do not easily become homeless. Not only unemployment but also various factors influence the downward path from mainstream society to life on the streets. On the contrary, those who are integrated into society primarily through work as well as those in unstable jobs also can end up homeless. When these individuals lose a job, get older or become sick, they tend to appear on streets.

Young unemployed people referred to as NEET and freeter do not appear homeless on the streets so much at this time. The main reason may be maintained support from their families. Living with their parents especially prevents their exclusion and decline in housing status. According to the recent survey on NEETs, about 80 per cent of them live with their parents (JILPT, 2005). Another reason may be that young people are believed to be more suitable for work in the information industry and service industries. Today's labour market requires workers in these industries. If a person has a family to live with and the family has a house, and if he/she is younger than 50, the risk of becoming homeless is much smaller. However, the more drastically the family structure and labour market changes in future, the larger the risk of exclusion and homelessness may become. In fact, some scholars have sounded a warning that the proportion of the older age group of NEET, between 30 and 34, is increasing and their parents, who support them, have started to retire from the labour market. Thus, the end of support from parents is coming (Kosugi, 2005).

The Independent Living Policy for the homeless classified various groups of homeless people according to working ability and includes only those acceptable to the labour market. However, the policy contains some critical contradictions. One is that the public policies do not expand employment itself but just encourage employers to hire the homeless and homeless people to apply for jobs. The second is that the policy itself can be the process that excludes those who do not fall within the bounds of categorization. Efficient inclusion policies need to be selective in nature, therefore, they may create new means of exclusion as a result. Those who are not selected by inclusion policies have started to be despised and stigmatized as they fail to meet the social obligation to work. The third is that inclusion-through-work never resolves the instability of those who can only link to society through work. The Type 2 of homeless people has only been connected to communities through work before becoming homeless. They have no choice but to devolve to the street when they lose their job, even though they have achieved the independence the policy is concerned with. Type 2 people need contact with society through various means, considering their lack of human 
capital, the lack of family support and the fact that many have lived for a long time in job-associated accommodation. What is perhaps necessary is to regenerate contact with the community rather than work. The final contradiction is that the inclusion-through-work policy is not accessible by the most excluded.

The housing-first policy (Moving to Community Policy) in Tokyo sought to resolve these contradictions. The success of the policy may lie in the superiority of inclusion-through-housing over inclusion-through-work in the following two respects. First, as the policy does not tend to select or exclude people by assessment of employability it has more potential for the recapturing of multi-dimensional social rights through stabilization of community life. Inclusion-through-housing may provide greater opportunities for Type 2 and 3 people who have not been included in the community through normal housing practices. Yet, this also has its limitations since it only involves temporary work and lacks an income provision element. Few people can live only on rent support. Thus, welfare officers have become concerned that the housing-first policy may increase the number of social assistance users and have begun to object to the continuation of the policy. In fact, many users of the inclusion-through-housing policy have become users of public assistance. Considering the average age of homeless people is 55, the number of social assistance users will definitely increase in the near future.

From the viewpoint of accessibility to social assistance, those who are registered as residents have easier access to the system than rough sleepers who are not regarded as formal residents. The Tokyo Metropolitan Government is planning to expand the policy, aiming at total clearance of illegal occupation of public spaces by homeless people. Meanwhile, welfare offices of local wards are basically against this direction in policy. Expansion of the policy will increase the number of social assistance users at the end of the day, which will also expand the cost of social assistance for ward offices. Moreover, it is generally believed that an increase of social assistance users will expand welfare dependency, which conflicts with the Independent Living Policy for the homeless.

These contradictions and limitations cannot be resolved unless policy addresses social exclusion directly, with homelessness policy redirected from its independence-centred approach. Inclusion is not a synonym for independence. The process of facilitation of inclusion in society should be more comprehensive and include through-work, through-housing, through-income approaches as well as the restructuring of social networks. Considering Type 2 and Type 3 homeless people who have the least resources, the policy needs to offer multiple processes of inclusion to one homeless person simultaneously, but it should not set separate programmes of inclusion-through-work, inclusion-through-housing and through income provision. At the same time, it must not exclude those who do not fall into each category.

In 2005, the new job programme was added to Seikatsu Hogo Ho (social assistance) as well as child allowance for single mothers. The new job programme 
is to reintegrate as many users of these two systems as possible into the labour market. However, unlike the Independent Living Policy for the homeless, this job programme is based on income provision. These additions should be welcomed as a safety-net policy and an inclusion policy can work together to tackle both poverty and social exclusion. Previous homelessness policies of inclusionthrough-work and inclusion-through-housing, discussed in this chapter, critically lack income support measures. However, as I suggested, inclusion-through-work carries a number of contradictions. There is also a risk that participation in the job programme may become an absolute condition for receiving social assistance. In order to achieve better consolidation of the safety-net policy and inclusionthrough-work policy, more working age people, that is, middle-aged homeless people, should be accepted as users of social assistance. Moreover, the need for a comprehensive execution of a housing allowance system in addition to income support measures of Seikatsu Hogo Ho and child allowance has become urgent in Japan. This chapter shows that housing support is more effective than job assistance in the social inclusion of homeless people. Furthermore, housing support is also necessary for NEET and freeters to be independent from their parents and to be able to settle into communities. It will also help to strengthen low-income households and reduce their vulnerability. Today's socio-economic changes can be seen in the collapse of the traditional family system and mutual aid within the system. In this case, greater inclusion in various processes including housing will become crucial. The characteristic exclusion processes in street homelessness, and the inadequacies of the government's inclusion policies identify the need to diversify routes of social inclusion in today's Japan.

\section{References}

Bramley, G.. (1988) The definition and measurement of homelessness, in G. Bramley, K. Doogan, P. Leather, A. Murie and E. Watson (eds) Homelessness and the London Housing Market, Occasional Paper 32, Bristol: SAUS Publications, pp. 24-43.

Cabinet Office (2003) White Paper on the National Lifestyle 2003 - Deflation and Freeter, Tokyo: Cabinet Office.

Cabinet Office (2005) White Paper on the National Lifestyle 2005 - Perceptions and Lifestyle of Child-rearing Generation, Tokyo: Cabinet Office.

Gray, J. (2000) Inclusion: a radical critique, in P. Askonas and A. Stewart (eds) Social Inclusion: Possibilities and Tensions, London: Macmillan, pp. 19-36.

Handler, J.F. (1992) The modern pauper: the homeless in welfare history, in N.J. Robertson and M. Greenblatt (eds) Homelessness: A National Perspective, New York: Plenum Press.

Handler, J.F. (2004) Social Citizenship and Workfare in the United States and Western Europe: The Paradox of Inclusion, Cambridge: Cambridge University Press.

Harvey, D. (1990) The Condition of Postmodernity: An Enquiry into the Origins of Cultural Change, Oxford: Blackwell. 


\section{Masami Iwata}

Iwata, M. (ed.) (2000) Rojo-Seikatsusha Jittai Chosa (Report on Rough Sleeping in Tokyo), Tokyo: Toshiseikatu Kenkyu-kai.

Iwata, M. (2003a) Commonality of social policy on homelessness: beyond the different appearances of Japanese and English policies, European Journal of Housing Policy, (3)2: 173-91.

Iwata, M. (2003b) Homelessness in contemporary Japan, in M. Izuhara (ed.) Comparing Social Policies: Exploring New Perspectives in Britain and Japan, Bristol: Policy Press, pp. 191-210.

Japan Institute for Labour Policy and Training (2005) Wakamono Shugyo Shien no genjo to kadai (Study on Career Formation Assistance for Young People), Tokyo: JILPT.

Kennett, P. (1999) Homelessness, citizenship and social exclusion, in P. Kennett and A. Marsh (eds) Homelessness: Exploring the New Terrain, Bristol: Policy Press, pp. 3760.

Kitagawa, Y. (2005) Jiritushien-senta riyokeikensha kikitori chousa (Independent living centre former user survey in Tokyo), Shelterless, 25: 153-70.

Kosugi, R. (2005) Freeter and NEET, Tokyo: Keiso-shobo.

Levitas, R. (1998) The Inclusive Society? Social Exclusion and New Labour, London: Macmillan.

Lister, R. (2000) Strategies for social inclusion: promoting social cohesion or social justice? in P. Askonas and A. Stewart (eds) Social Inclusion: Possibilities and Tensions, London: Macmillan, pp. 37-54.

MHW (2000) Homelessness taisaku gaisann yokyusho (Budgetary Request for Homeless Policy 2001), Tokyo: Ministry of Health and Welfare

Percy-Smith, J. (ed.) (2000) Policy Responses to Social Exclusion: Towards Inclusion?, Buckingham: Open University Press.

Sparkes, J. and Glennerster, H. (2000) Preventing social exclusion: education's contribution, in J. Hills, J. Le Grand and D. Piachaud (eds) Understanding Social Exclusion, Oxford: Oxford University Press, pp. 178-201.

Social Exclusion Unit (1998) Rough Sleeping, London: Stationery Office.

Statistics Bureau (2003) Population Census 2000, Tokyo: Statistics Bureau.

Stewart, A. (2000) Never ending story: inclusion and exclusion in late modernity, in P. Askonas and A. Stewart (eds) Social Inclusion: Possibilities and Tensions, London: Macmillan, pp. 55-72.

Tokubetsuku-Jinji Kosei Jimu-Kumiai (2003) Kinkyu Ichijihogo Senta Otaryo Riyosha Chosa (The Report on Users of the Ota Shelter), Tokyo: Tokubetsuku.

Toda (2005) Homuresu chiikishienjigyo no seikatsu sapoto (Personal social support under the moving to community policy for the homeless), Shelterless, 25: 82-9.

Wright, T. (1992) Out of Place: Homeless Mobilizations, Subcities, and Contested Landscape, New York: State University of New York Press.

Yasue, S. (2005) Mottofukaku nojyukusha no nakanihaitta seisaku wo (Better policy for homeless people), Shelterless, 25: 94-106. 


\title{
8 The Japanese home in transition

\author{
Housing, consumption and \\ modernization
}

\author{
Richard Ronald
}

\section{Introduction}

This chapter deals with the interaction of Japanese tradition and modernity in the re-signification of the home as an owner-occupied family commodity fitting with middle-class formation and the maintenance of social and familial relationships. The focus will be on the development of Japan as a mass homeowner society and modern housing culture which reflects the particular nature of Japanese social relations and its peculiar manifestation of modernity. The Japanese home has long been culturally embedded as the embodiment of Japanese harmony and the canon of Japanese social organization (Daniels, 2001). However, the conditions of homes and families have undoubtedly been volatile and Japanese society has experienced radical changes in the constitution of households, social contracts and welfare exchanges, housing aspirations and preferences, tenure rights and relations as well as in the built environment and urban living arrangements.

I consider the changes in the meaning of house and home and the physical form of dwellings as crucial elements that have mediated the interaction between the self, society and the built environment in Japan's modern era. I look at the housing context from the Meiji restoration in the latter nineteenth century through to postwar reforms and, finally, from the post-bubble era which began with the 'lost decade' of the 1990s and has formed the basis for a new approach to governance and social relations in the twenty-first century. In this period housing has been central in the interaction of conservative elements and forces of change, and as the basis of identification and consumption that has formed a nexus of social relations. Previous chapters have considered in detail system elements and social relations in terms of policy change and socio-economic developments. This chapter aims to provide more of a sociological, anthropological and socio-historical context for the consideration of housing and social transformation, locating the home more centrally in analysis. This constitutes an interpretive contextual framework for 


\section{Richard Ronald}

understanding the indigenous and comparative significance of social, individual and cultural processes in Japanese housing and social change.

Japan can be considered an ideal laboratory for exploring the comparative dimensions and limitations of theories that claim to be universal, due to the outstanding influence of socio-cultural processes on social practices, and therefore provides an insightful context within which to examine and reconsider many of the assumptions concerning the home as a nodal point between the self, the family and wider society. Kemeny (1992) has argued that the way in which households relate to dwellings is an area that remains unexplored systematically by researchers, while the comparative significance of this relationship has also been neglected (Ronald, 2004a). A focus of my analysis is thus housing practices and values and relationships between households and their homes, where family dwelling space has been a key point of interaction between households and society that has been radically transformed by Japanese modernity while maintaining elements of tradition and culture.

From a western housing perspective, contemporary Japan can be considered a mass homeowner society (Hirayama, 2003a; Forrest et al., 2003; Ronald 2004b), as it has demonstrated substantial market demand and policy commitment to owner-occupation, specifically in the post-war era, characterized by residualized public rental housing systems and the dual market characteristics of western home ownership orientated countries, or 'homeowner societies', like in Britain, North America and Australia. The development of Japan as a modern mass home ownership system, as well as the shape of social modernization, stands out in comparative context, as while market based owner-occupied housing systems have been strongly connected to processes of globalization, local housing cultures and practices have been similarly implicated in social divergence. Moreover, there is little consensus on how to interpret social changes in Japanese society as traditional and ethnocentric models based on western social structures and subjectivity are difficult to apply (Clammer, 1995).

Japan experienced similar transformations to western societies, where social preferences for home ownership and domestic privatism were largely created and manipulated (see Kemeny, 1992; Rybczynski, 1986). However, the characteristics of this transformation have been shaped by cultural forces and indigenous structures of social control. The nature of capitalism in Japan is also strongly differentiated from patterns in other modern industrialized societies. Essentially, while Japanese society has experienced exceptionally rapid modernization, industrialization and urbanization, it has achieved this through traditional and culturally marked social processes and relations, rather than rationalized and socially disembedded ones, which have maintained the hierarchical and interdependent nature of social relations.

Critically, the house and home, embedded socially, culturally and materially as ie in Japanese language and social practice, has been a conceptual and physical 
centre in the maintenance of traditionally defined social relations. The idea of the Japanese house and family has been pivotal in maintaining a sense of continuity through radical upheaval and social, economic and political transformation. My analysis, however, illustrates that housing and the home have been far from stable and contiguous and have in fact been a significant mechanism for the achievement of modernization and transformation of social identities and social relations. The key characteristic of $i e$ is in fact change.

\section{Pre-war housing: Japanese modernity and the reinvention of the home}

The year 1868 marks the beginning of an era of modernization and rapid urbanization in Japan, although it is a remarkably peculiar one that has no parallels in the West. Although Japan had been dealing more seriously with issues of westernization and modernization since the arrival from America of Perry's black ships in 1853 demanding the opening of trade relations, 1868 marks the Meiji restoration, seen by many as a radical watershed for the beginning of modernization, which has often been equated, mistakenly, with westernization. This revolution was, however, deeply conservative. How many modern revolutions have sought to put the Emperor back on the throne? While it was in fact a revolt against exploitation and injustice, by calling it a restoration it refrained from casting aspersions on the system and did not undermine the basic fabric of social existence and social relations (see Clammer, 1995; Benedict, 1947). Socio-economic reconstruction under the Meiji regime, which sought to drive industrial capitalism, radically transformed the country. At the beginning of the twentieth century approximately 15 per cent of Japanese lived in cities. By the end of the century around 80 per cent of the population lived in urban areas. Modernization, therefore, while from the outset characterized by conservatism and the preservation of cultural tradition, was radical.

The character of Japanese social-modernity is largely contested between those on one side who consider Japan essentially pre-modern (due to the persistence of values of group orientated values, social harmony, and hierarchical and authoritarian social relations) and, on the other, the epitome of the postmodern society (due to the lack of meta-narratives and the importance of signification in Japanese social life). Berger (1979) suggests that modernity has five major characteristics: abstraction, futurity, individuation, liberation and secularization. Japan challenges this western model for, as Clammer suggests, a characterization of Japanese society contains: concreteness, tradition as a way of handling change, group orientation coexisting with many varied if subdued forms of individualism, and a strong emphasis on fate and desire for continuity (1995: 57). Essentially, structures which mediate between individual life and the wider, changing structures of society are different in Japan, which has led to a form of modernity with its own 


\section{Richard Ronald}

cultural logic. Housing and the home, I argue, has been a critical structure in this mediation.

The elements of home, the house and the built environment have been a critical axis for social identities and have been radically transformed in order to facilitate social change. At the same time they have retained conservative, traditional elements which have maintained a level of continuity facilitating social relations and authoritarian control. I now consider where modernization has interacted with conservatism in forms unfamiliar in western modernity. The basis of this transformation exists in pre-war society going back to the Meiji restoration.

\section{Reinventing the Japanese home}

The Japanese home is characterized by a strong interdependence on the order of the family and the physical order of the house, and is thus considered the materialized order of the family (Engel, 1964). However, the idealized order of the house and home has been more important in Japanese society. Essentially the Japanese home has acted as a medium and embodiment of cultural values and an ideological system that has facilitated social change whist maintaining a vision of continuity which has supported social order and hegemony. In this section I consider the nature and role of $i e$ in the early period of Japanese modernization where it has been considered a rudder for the social and moral orientation of the individual. It has guided institutional relations and set out the respective responsibilities of the state and family. Ie has also mediated changes in the physical shape of the home, urban living and social development.

So what is ie exactly? To speak of the traditional Japanese family is to speak of a very distinctive institution identified by the word ie, implying house, family or lineage (Sand, 1998: 191). Koyano (1996) emphasizes lineage in the conceptualization of $i e$, where contiguously succeeding generations define what the family is rather than the contemporaneously contained material unit of the family itself. Under the Meiji civil code (1898) ie was an organizational structure under which the paternal head of household held authority with a rule of one-son succession (Mayokovich, 1978; Nasu and Yazawa, 1973). The system arguably originates in Confucian doctrines and principles of loyalty to the state or the emperor, filial piety, faith in family and respect for seniority (Morishima, 1988). The concepts of ie system and ie society have dominated discourses and analyses of domestic social relations and are considered underlying structures of pre-war Japanese society.

The Meiji civil code essentially formalized patrilineal relations with responsibilities of families, particularly the head of the family, enshrined in law. Under this system the family head was provided with privileges and powers necessary to fulfil obligations to the emperor, state and society, as well as maintain the name, assets and social status of the family for the next generation. There 
was a strict division between the succeeding child and other children, with the eldest son, as future head of household, having clearly defined privileges, duties and obligations. Such a traditional family system reinforced normative values of the family, and discounted individual wishes and choices. The concept of ie was essentially an ideology that guided household and housing practices, and influenced socialization processes and broad-scale social relations.

Modern families can be understood in terms of the transformation of the idealized notion of ie into a more nucleated modern form (Ochiai, 1997) convergent with the concepts of modernity and owner-occupier living as well as tradition and continuity of the family across generations. Post-war democracy is regarded the source of nuclearization and enlightened rationalization of domestic behaviour, however, the principles of $i e$ persist in terms of reciprocal obligations and welfare responsibilities of the family (Izuhara, 2000). Discourses have created an idealized image of Japanese family life that ignores radical changes in households and the transformation of its meaning and form. Essentially, the family has been understood in terms of this framework which has effectively promoted the decontextualized image of the house and home (Daniels, 2001). Discussions of domestic life in modern Japan have thus positioned themselves along an axis between two political poles of family relations between democracy and authoritarianism (Sand, 1998).

While elements of Japanese home life are considered constant, such as tightly knit cohabitant families, family privacy and the role of the wife as housekeeper and mother, the tradition of the Japanese home is, in large part, a construct of modern social reformers. Meiji (1868-1912) and Taisho (1912-26) period reformers were influenced by the rich language of the home and middle-class domesticity in the West. New domestic discourses emerged that sought to establish a set of norms and practices regarding the home as a centre of family and moral life which fitted Japan. These norms eventually developed in architectural forms and socially comprehensive discourses. As the western concept of home was found to be inadequate to the Japanese situation the more novel concept of katei (household) was adopted by early proponents of change. Katei was strongly associated with the role of the modern housewife and close parallels can be drawn with the Victorian cult of privatism and domestic life that had emerged in Europe (see Davidoff and Hall, 1987).

The conception of home and household relations that emerged in the early modern era was, critically, a dialectic resolution between two concepts and structures of domestic organization. Traditions of $i e$ were associated with a more aristocratic, authoritarian tradition and Bakufu (Shogunal government) custom, and katei, largely championed by Japanese social reformers, reflected modernizing principles of family life, and intimate and romantic notions of family relations. These two concepts were dichotic, one being indigenous and feudal, and the other being modern and exogenous (Sand, 1998). The former had embedded loyalty 


\section{Richard Ronald}

and social order in domestic relations in feudal society, the later was considered necessary for Japanese progress in social and industrial development. The house and home consequently became a battleground between forces of conservatism and modernization. The new domestic ideal was more middle-class and new gender roles and new moral meanings imbued with material practices were invented to provide substance to images of modern Japanese families and homes (Nishikawa, 1995).

Japanese houses had traditionally been occupied by children and adopted children, parents-in-law, other in-laws, concubines and lodgers, who lived in integrated housing units where sleeping communally on the floor was the norm, and rooms were separated by shoji or fusuma (paper screens) which provided little privacy. This was considered inappropriate to conjugal relations and the upbringing of children and clashed strongly with new ideas of family bonds and harmony. The form of $i e$ that was normalized in early twentieth-century discourses and household organization was thus largely an idealized synthesis of the traditional ie household and katei images of modern domesticity, strongly influenced by images of western middle-class domesticity, which served the interests of modernization. Thus while ie traditions and values had been substantially transformed, they maintained a sense of continuity about the permanence and centrality of family life and custom. The synthesis of ie and katei also involved spatial transformations.

Normalising the home in Japan required redrawing its contours of domestic space and reappointing its interior. Two fundamental spatial problems had to be solved in the invention of Japanese domesticity. First, to bind family to place, and give the bond normative significance, families had to be persuaded not to merely cohabit but to exhibit family solidarity in some concrete form ... Second, to articulate the priority of family over other social groups, a house design was needed that would segregate the cohabitant family from non-kin, and the outside world.

(Sand, 1998: 193)

While husband and wife bonding and childrearing were initially the focus of discourse in the early modern period, parents-in-law crept back into the idealized image of the family home. The family meal taken from a single table also became iconic as it embodied the pleasures of family intimacy and ritualized family unity. This was far from traditional, as when and where meals were taken under the premodern ie regime reflected one's status in the hierarchy of the house. Meals were also taken on individual trays with status differences making it inappropriate for two people to eat from the same surface (Koizumi, 1979: 318).

Most importantly, in the development of the home in modern Japan as a mechanism for social change, was the association of social class or social status with the new idea of the Japanese home. Leading up to the first period of radical 
urbanization in the 1920s the image of modern homes strongly distinguished the new professional middle classes from the traditional urban bourgeoisie, associated with feudal power relationships and traditional aristocratic houses, in the broader hierarchical sense. The middle classes, who were increasingly defined by their consumption of goods and household practices, were associated with western opulence and a healthy society.

Although the meaning and constitution of $i e$ has been transformed, it still largely functions to discriminate the 'Japanese Family' from a more regular or universal notion of 'families'. The Japanese family as ie can also therefore be linked to Nihonjinron and other ideologies which have asserted Japanese uniqueness and which function to preserve conservative social relations. Nihonjinron values, or theories of Japaneseness, assert that Japanese people share important characteristics including; the idea that they are a homogeneous group of people unique and distinct from other peoples; that they are naturally harmonious; and that society is based on hierarchical interpersonal relations that necessitate respect for authority (Goodman, 1992: 11). Nationalistic ideologies were central to the rapid industrialization and militarization of Japan, and Nihonjinron (the more contemporary form of these ideologies), Confucianism and other parallel ideologies have been critical in defining a common hegemony and identity, and have been important in maintaining stability during radical social changes and the erosion of meanings and identities in Japan's modern era (Befu, 1989; Dale, 1986). These values are argued to represent the ruling class ideology in the way they have structured social cohesion, nationalistic sentiment and disguised inequalities and instability created by economic growth. Although Japanese homes and houses, via the perpetuation of a form of $i e$ in social values, have been embedded in theories of Japaneseness and bound to Confucian practice, this belies transformation and modernization of housing and what Cannadine (1983) refers to as 'invention of tradition'.

\section{Reinventing the Japanese house}

Inside and outside Japan, discourse on the Japanese house, with its 'delicate elegance' has been perceived, or at least caricatured, as the embodiment of Zen and harmony, and the canon of Japanese social organisation (Daniels, 2000). Architecturally and spatially Japanese houses are thus strongly associated with $i e$ and Japanese social order. They essentialize space and define social relations between the family within and the society without in ways largely unimaginable in other cultures. Modernization and social transformation in Japan thus has had to maintain central meaningful elements of the Japanese house whilst in reality the built environment of the family dwelling has changed substantially. The house has become multifaceted: as an object of household consumption which marks 


\section{Richard Ronald}

social inclusion and social status; and as an object of tradition marking social affiliations with others within the family and community.

Watsuji, writing in the 1930s on the connection between the house and Japanese social life, identifies how the built unit reflects or structures relations between the self and society. While the European house has thick walls and stout doors which is a construction stressing individuality and separation, the Japanese house has sliding doors which provide an element of division but only within the unity of mutual trust and not as the desire for separation. Just as there is no distinction between individual rooms in the house, where spaces cannot be locked apart, there is no distinction of the individual and society as a whole. Above all the physical house exhibits an internal fusion that admits no discrimination (1988: 4). The house marks the realm of inside and outside as unmistakably different. The house continues in Japan - and continues not just as a formal entity but as a determinant of the Japanese way of life (1988: 5).

The relationship both physically and socially between the interior and exterior of a house has been strongly emphasized in anthropological accounts of Japan. The concepts of uchi and soto signify spatial meanings of inside and outside respectively, with $u c h i$ used literally to denote the home itself. Hendry (1992) illustrates how individuals are socialized in terms of $u c h i$ and soto group identities which structure identifications and affiliation with groups discernible as 'inside' which are opposed to those 'outside'. The house thus embodies the principles of social relations and the relationship of the individual to others. The state is also connected to this nexus as the fence that surrounds the house and household is broadened conceptually to become the boundaries of the state.

Through every age, Japanese have striven to eradicate selfishness within the family and to realize fully the fusion of the self with the other ... The house represents the realisation through the family, of a distinctive Japanese relationship - the fusion of calm passion with material selflessness ... The concept of house in Japan takes on a unique and important significance as, if you like, the community of all communities.

(Watsuji, 1988: 4)

Clearly, the house in Japan has overwhelming social significance and the concept of $i e$ which ties the family to the house is strongly integrated. Its traditional material form, however, was far from adequate for processes of modernization and urbanization. Construction was based on principles of ephemerality where houses were considered vulnerable to the seasons, strong weather and earthquakes, unlike the eternal family within. Houses were flimsy and ill suited to practices of modern consumption and family life. At the beginning of the twentieth century, the physical unit of the house posed a problem for the social movements who had transformed the domestic meaning of $i e$. The lack of corridors and privacy, with 
rooms opening on to each other, was increasingly seen as a problem in terms of relations between family, servants and outsiders such as neighbours and guests (Sand, 1998). Nevertheless there was strong attachment to the Japanese house as a medium for the transmission of Japanese values and the structuring of a unique subjectivity which was considered essential to social order and human relations.

Demand for transformation in Japanese housing to fit modern needs and to adjust to the changing relationship between people and houses became increasingly felt in the late Meiji period. More western-style houses began to appear in the Taisho period, but were unsuitable to Japanese sensibilities as they failed to meet many spatial criteria that were perceived as necessary for household relations and psychological well-being. The 'eclectic-style house' (wayo setchu) eventually emerged which incorporated both western and Japanese elements and facilitated many of the ideals of Katei. Male and female space, as well as family and guest spaces, became more differentiated. Tatami (traditional fixed matting) space became associated with a place of purification and segregation of the family from society and, most importantly, family activities became the normative focus of house design (Sand, 1998). The separation of work from leisure in the home began to be realized in house design, which increasingly enhanced the relaxation qualities of the home. Household management and the housewife's role were also raised on the architectural agenda and became manifest in more scientific approaches to the organization of domestic space.

In 1915 the Kokumin Shinbun (People's Newspaper) sponsored the first home exhibition in Tokyo and published a number of essays on the 'ideal home' (Riso no katei). The model houses featured encapsulated the principles of family-orientated design and modern domestic management. The exhibition signified the advent of an era in which images of the dwelling and domestic improvements became market commodities and exhibitions at which the houses were actually sold followed years later (Sand, 1998: 206-7). Identified with the social characteristics of a new urban middle class, the house became a node between social reform and the emerging consumer culture.

In the period after the Second World War western building design and materials would be increasingly incorporated and mixed with traditional elements of Japanese housing (see Hein et al., 2003). What was important in this earlier period was that houses became normalized as consumable objects that signified social status, and, moreover, incorporated ostensibly contradictory elements of westernization, modernization and Japanese tradition and continuity. In common with western societies were aspirational models of dwelling and dwellings, and a domestic set of relationships identified with lifestyles and values of the middle class. This is not to say that the majority of Japanese at this time were middle class. The origin of the Japanese urban workforce had been rural and their experience as tenant farmers and then urban labourers was dominated by hardship. Civil society and individuals in this period tended to be politically docile, which inevitably 


\section{Richard Ronald}

contributed to the lack of concern with urban planning and housing standards. In short, the nature of Japan's brand of capitalism was radical and the citizenry passive, which contributed to the creation of poor housing and environmental conditions (Yamada, 1999; Sorensen, 2002).

This is a very different set of social relations compared to western social contexts at this time where the inadequacy of working-class housing conditions had led to pressure on governments to rethink housing approaches. In Britain poor housing conditions were associated with social unrest and class tensions, and pressure was put on the state to provide better housing and urban environments in order to resist bolshevism (Merrett, 1982). Following the return of soldiers from the First World War the public cry was for 'homes fit for heroes' to live in. In Japan, alternatively, rapid social and urban change was achieved along with traditional values of harmony, communality and state authority. This facilitated the state's ability to steer society towards economic growth and militarization despite poor urban conditions and considerable sacrifice and hardship on the side of workers.

The pre-war period redefined and reoriented Japanese society and housing took a lead role in both social discourse and the restructuring of living. Consumption and identification with middle-class mainstream identities would become more critical after the Second World War, as would the significance of owner-occupied housing. Critically, the ideal of early modern middle-class housing was rented rather than owned, and early modernizers set out the need for more 'convenient and complete' rental houses in order for progressive young couples to live apart from their conservative parents (Sand, 1998). Owner-occupied housing would become definitive in patterns of post-war urban development, while the new ideal of the family home would be modified to fuel housing purchase and mass middleclass formation.

\section{Post-war housing: transformations in identity and space}

Defeat in the Second World War caused a radical reorientation of society. Surrender brought about a crisis in identity and direction, and traditional nationalist ideals were fundamentally undermined. Modernization was considered vital to the rebuilding of Japan, and even more pressure was put on the singular goal of catching up with the West through tireless economic endeavour. By the 1950s Japan's new leaders were reorienting Japanese values around a set of goals within which economic rebuilding would ensure Japan's position amongst the 'advanced' nations of the world. At the same time the traditional values of the Japanese would be drawn upon in this rebuilding to ensure the reassertion of the society and culture.

Housing in particular became a critical element by which modernization could be achieved, and its role in driving economic expansion and constituting an aspirational residential lifestyle became central to economic and social policy. 
The ideology of modernity manifested itself in the transformation of the physical landscape. House-building techniques, the development of the construction industry and changes in the physical forms of residential units and urban environments encapsulated and mediated the set of social values that dominated the post-war period. Social modernization could also be achieved through restructuring the urban and residential system in order to engineer a 'social mainstream' (see Hirayama, in this volume), which was driven by new ideological values that asserted the significance of Japanese unity and social harmony in terms of middle-class identity, family self-reliance and economic productivity rather than hierarchy, obedience and national military strength.

The expansion of home ownership and the normalization of social mainstream, middle-class identities characterize this period and I will address, in the following section, the significance of social identification and social class processes in the relationship between housing and society. I also address the significance of physical changes to homes and urban environments. The post-war period of rapid economic expansion saw Japan go from military defeat, with decimated cities and considerably diminished industrial capacity, to the world's second largest economy within 23 years. Social and environment changes were even more dramatic than in the previous period, but the housing system and housing consumption, which would be unrecognizable to Meiji and Taisho reformers, maintained traditional identifications and authoritarian power relations.

\section{Economic growth, home ownership and the social mainstream}

The American post-war occupation initially set out to transform Japanese society in terms of 'revolution from above' (Dower, 1999). The process involved dismantling several giant conglomerates (zaibatsu) and instigating rural land reform by breaking up large landholdings, which were considered undemocratic forces. The democratizing process also called for the renunciation of $i e$ ideology, and the concept of ie was removed from the new constitution of 1948 and the new civil code of 1947. New laws stressed individual rights and equality amongst family members (including greater equality between male and female members in principle), leaving the succession of head of household with little functional meaning except ritual duties. Although ie was dissolved legally it continued to be an organizational principle and a point of social and cultural identification for modern families, although further abstracted from its traditional form. In part the result was the expansion of nuclear households, although intergenerational living and welfare exchanges persisted. Post-occupation governments rhetorically supported the process of democratization. Nevertheless, many characteristics of pre-war governance and urban planning continued, including the focus of state resources on economic development, the weak relationship between state policy 


\section{Richard Ronald}

and civil society, the dominance of central government, unregulated corporate activity, and principles of self-reliance for households and neighbourhoods (see Sorensen, 2002; Hein et al., 2003).

Economic growth largely became an end in itself, and most resources were mobilized into the service of expansion while the private sector was given substantial freedom. While overall wealth increased substantially the environmental and personal costs were high. Nagamine identifies that one of the major factors in accounting for the prosperity of the Japanese economy is that the people have opted to tolerate, rightly or wrongly, a meagre resource allocation for their living conditions, thereby leaving the maximum amount of resources for industrial development (1986: 52).

While post-war housing policy was essentially considered economic policy and sought to support industrial growth, it also sought to quicken the formation of a 'social mainstream'. Critically, priority was given in housing subsidy to the expansion of the middle classes, perceived as the most self-reliant and economically productive group (Hirayama, in this volume). Thus working households who were best able to secure their own private accommodation were given more support. Owner-occupation orientated policy was thought to encourage self-help and the greater reliance of households on social networks rather than the state. This strategy was considered most likely to enhance economic development and stability and therefore linked economic and social objectives in state policy and ideology.

Significantly, the intention of creating a core mainstream, owner-occupier and self-reliant social class to support the needs of mass economic expansion also strongly reflected Japan's approach to modernization. The concept of a social mainstream encapsulated traditional ideologies of social homogeneity with new ideologies concerning modern consumption orientated society. Moreover, home ownership was central to these ideologies as it reflected both the principles of family based self-reliance and a unified middle class. Economic filtering or 'trickle down' was conceived to rationalize the situation of prioritizing home ownership and middle-class housing. This is not to say that poorer households were not provided for, but support for the people who were thought to form the core of society was given preference (Hirayama, 2003b).

Owner-occupation became definitive in what has been described as the 'Japanese dream', and growth of this tenure was increasingly normalized (Hirayama, 2003a, 2003b). By the late 1950s the rate of owner-occupation had reached more than 60 per cent, from pre-war levels of less than 30 per cent urban home ownership (see Hayakawa, 1990). The drive toward home ownership was increasingly justified as a reliable and universal means for families to improve their housing conditions and accumulate capital. What emerged was a housing ladder system that had a strong hegemonic impact in defining social inclusion and normalized lifestyles, with owner-occupation representing a social ideal that reified the social 
mainstream and reinforced values associated with an ideology of middle-class stability. This ladder system defined the life-course in the social mainstream and dictated aspirations. Critically, ownership of a house came to signify a particular social status and inclusion in mainstream society while increasing household assets and the transformation of citizens into owner-occupiers reflected the modernist ideology of Japan as an advanced social and economic power.

In the environment of early post-war Japan social and economic conditions made owner-occupation attainable and realistic for large segments of the population, even if workers could not afford a home immediately. In the 1950s and 1960s owner-occupied housing was more affordable and government housing loans provided access to necessary funds for middle-income workers (Yamada, 1999). The economy expanded considerably and wages grew. Most working people were salaried monthly and Japan's employment system assured a worker's lifetime employment, which contributed to stabilizing income. By contrast, the growth in the levels of, and preference for, owner-occupation in western societies grew erratically and occurred over a longer period. In Britain, for example, it was not until the 1980s and the introduction of comprehensive subsidies that home ownership really took off. In earlier decades home ownership was not a realistic alternative to renting for the working classes who thereby remained 'trapped' in the rental sector. Post-war housing policy was initially dominated by welfarism and the building of mass public rental housing.

The transformation to an owner-occupied system was significant socially and ideologically. It redefined modern Japanese lifestyles and aspirations and reorganized households around a model emphasized by the state and corporate interests. Owner-occupation not only constituted an accumulation of assets and provided security for current generations, it also ensured some security for future generations who would inherit it, involving a build up of wealth across generations (Hirayama and Hayakawa, 1995). It thus became integrated into the developing ideal of $i e$ as it reinforced the significance of the house, family heritage and continuity through the generations via inheritance. Land price inflation also helped fuel the 'land myth' and the 'fetishization of space' where land was considered precious and had a special, essentialized status and was thought to increase in value in perpetuity (Mizuoka, 2004).

Those who bought up land in the early post-war years were able to build assets that increased tremendously, which emphasized the significance of family land ownership and inheritance. The oil crisis in 1973 temporarily interrupted the pattern of land price increases which challenged the security of family housing assets. The government responded with a series of measures (see Hirayama, in this volume), which reinforced home ownership consumption and the cycle of price appreciation contributing to the formation of the economic bubble. 


\section{Richard Ronald}

\section{Housing, modernization and the built environment}

The form of the built unit of the home and urban space experienced more radical change in the post-war environment as a result of the interaction of tradition and social and economic modernization. For Hein, while planners and technocrats exhibited considerable continuity in approaches to the built environment, which reflected the continuation of existing authoritarian and centralized power structures, architects believed their role was to translate the new condition of society into a tangible form (Hein et al., 2003: 243). The Second World War significantly diminished stock, and subsequent policy was initially concerned with re-establishing an adequate number of housing units. An intensive rebuilding programme meant that by 1968 the total number of housing units exceeded that of total households. The central purpose of five-year housing policy strategies was to improve housing conditions and enhance economic expansion, but they also reflected concern in Japanese society with modernizing the residential landscape and facilitating self-contained housing commodities for consumption by the type of social mainstream, middle-class families envisioned by post-war governments.

The form of Japanese dwellings was transformed between the 1950s and 1970s with a move away from traditional wooden housing dominated by multi-purpose tatami mat rooms, to more modern and westernized forms. One of the ways by which policy-makers and developers tried to make modern housing popular was the large-scale production of danchi housing. Danchi are multi-family housing estates based on concrete structures made up of apartment blocks. These were considered modern housing for modern families. They materially epitomized an approach to spatial as well as social change in the drive toward economic expansion and modernization. The modernization of family space was epitomized by the introduction of the 'n-DK' model of housing layout (see Hinokidani, in this volume), which redefined space in the home in more rational terms and marked a new stage in the commodification of dwelling units.

These modern homes were built with dining-kitchens, where householders sit on chairs to eat, and separate bedrooms, where individual privacy was secured. Intergenerational co-sleeping, although traditionally valued, was increasingly perceived as uncivilized and antithetical to 'advanced' dwelling arrangements in the modernized West. Privacy was a new concept in twentieth-century Japan and had remained a rather esoteric concept throughout the pre-war decades. Privacy epitomized the new values Japan was being influenced by from the West and it represented a challenge to aspects of pre-war ideology that had enshrined the patriarchal family as the central unit of society. While it did not reflect an individualistic ethos directly, enhanced individual privacy did represent greater democracy in the household and a breakdown in the uniquely Japanese organization of space envisioned by Watsuji. Essentially, new forms of living spaces replaced 
traditional paternal hierarchies of space within the home, with private and social space that family members could enjoy more equally. Waswo (2002) suggests that housing reformers possessed both a scientific and social agenda. They sought to change the physical environment of dwellings in order to promote public health and influence household behaviour, following the principle of modernization of living spaces.

Innovation in the housing sector drove a resurgent construction sector that became a dominant force in the economy. Danchi living promoted the diningkitchen style of family space which stood out from traditional arrangements and reified more comprehensively the family image of katei reformers. Moreover, modern danchi living combined with the growing demand for new electrical goods and labour-saving devices that were more suited to modern residential units and lifestyles. The economic impact thus moved beyond the construction industry and into other sectors that contributed to economic expansion.

Waswo (2002) asserts that a particular type of family with a particularly middle-class make up became associated with danchi. By the end of the 1950s the concept of danchi-zoku (danchi tribe) had been attached to these families and lifestyles and for several years they became preponderant in housing aspirations and linked to the image of a middle-class mainstream lifestyle. The symbolic effect of representing modernity and modern lifestyles via the built form of the home can be considered a significant development in re-signifying the family home and commodifying the built form which was necessary in expanding the home ownership system. Redesigning, restructuring and reconceptualizing Japanese homes arguably marked a process of transformation of housing from dwelling to lifestyle consumption.

While bank loans became more available for the purchase of a broader range of housing, the government also began to relax loan conditions on condominium and second-hand housing purchases. Although danchi were not initially built for sale they were, with the expansion of the tenure, progressively sold off as condominium units. The built environment and images of owner-occupied housing subsequently diversified and condominium consumption became more central to the mainstream housing ladder.

Building techniques were also advancing in the production of single detached family housing. Traditional wooden housing units were increasingly demolished to make way for newer units which reflected more international styles in architecture and the use of concrete and prefabricated production techniques. 'Scrap and build' practices (see Oizumi, in this volume), which originated in traditional wooden housing construction, were integrated by construction companies into modern concrete housing construction. The concepts of ie, middle-class lifestyle, home ownership and the image of modern housing had, arguably, at this point merged, and the government focused on sustaining the economic mechanisms necessary for maintaining the home ownership dream. 


\section{Richard Ronald}

We can consider the first few decades after the Second World War as a crucial phase in the physical transformation of housing in Japan. Not only was the urban landscape and the character of the physical dwelling transformed, so too was what it represented and how households perceived this space. Housing thus has been a sphere within which post-war hegemony has been recreated and reasserted. In just a few decades Japan went from a private rental based system, with predominantly traditional wooden stock to a society of housing consumers with a modern housing stock where private ownership is considered natural. A relationship can arguably be discerned between the development of a post-war hegemony, the ideological influence of socio-economic expansion and modernization, and the development of the built environment and residential system. At the same time, while modern lifestyles of Japanese families have been emphasized, traditions of ie and Confucianism too have been emphasized by the state in housing practices as a means to provide a self-supporting family welfare system, to resist individualism and retain a collectivist ethos without recourse to universal welfare rights. The idea of $i e$ as a centred family space became more important to the maintenance of social stability and a sense of continuity, which in turn reinforced state power and legitimacy. Although modernism and Japanese tradition ostensibly appear contradictory, they have clearly been integrated by the principle and practice of housing and home ownership. This integration, however, is fundamentally mythical and symbolic.

Within the house itself traditional and modern elements have been reinvented and posed against each other. For Daniels the incorporation of tatami rooms into modern houses particularly reflects the juxtaposition of Japanese tradition and modernization. While the house is in reality a modern consumer object, the ideology of the Japanese home and harmonious family is perpetuated by touches of domestic tradition. "The notion of a tatami room as a place for nostalgic reflection fits with the strict division of work and home idealized in contemporary Japan' (2001: 216). For Moeran and Skov (1997) there are 'overlapping rhythms' of consumption in Japan, the quicker one indicating fast-changing fashion items and the slower one a 'consumption of tradition'. For Daniels, the Japanese house plays between both consumption forms and embodies both ideals through its mix of modern and traditional elements. One is about traditional identity, family and values, the other about a projected modern Japan.

Ideas of East and West, of tradition and modernity, are central in Japan's development of housing forms and living styles. While ideas of the nuclear family and the consumption of ostensibly westernized housing objects have developed, they have done so in the context of Japanese ideals of the harmonious family, social collectivism and elements of traditional housing and living. As such, housing has been central to social ideologies that integrate social changes into continuity. 


\section{Housing, identity and society}

The concepts of hierarchy and role are more clearly defined and prioritized in Japanese socialization processes and social relationships, and have been fundamental in shaping post-war housing and social-class relations. In forming a framework for understanding the context of changes in housing and Japanese society it is necessary to consider in more depth the nature of both social identities and social class relations which structure dwelling (in a society of mass owneroccupation), as consumption of identity and status. I go on to address in the final section the impact of the post-bubble economy, which has undermined the housing system and consequently the basis of identity, consumption and social hegemony.

How housing is used to express identity varies across cultures, but is a crucial to modern homeowner dominated societies as it is a central means by which middle-class social identities are communicated. All forms of identity depend on setting up contrast with those who are different, and these differences both separate and distinguish social units and also lead to various forms of interaction and communication (Rapoport, 1981: 12). In the case of housing, Rapoport differentiates the process of communicating identity internally, to members of one's own group or oneself, and externally to others and outsiders. In Japan, as I identified earlier, individuals are socialized in terms of uchi and soto group identities and thus signifiers which identify affiliation with the inside group norm have particular salience. Uchi originates from the word used for one's own home and, in the socialization process, binds the self and group identity together. As children get older the concept of uchi is applied to broader groups including neighbourhood community, classmates, etc. (Hendry, 1992). Essentially, relationships between the individual and the outside world are broken down into a hierarchy of concentric rings of affiliation. The house or home as a location, social space and metaphor is thus central in defining social relationships and identities.

Identities in Japan have been largely defined in the post-war period in terms of normalized forms of middle-class lifestyle fitting with the prevailing hegemony of homogeneity. As individual identities are more strongly incorporated into collective ones, and homogeneous social identities, consensus and uchi/soto relationships are emphasized, communication of in-group identities become more significant. Owner-occupation therefore, when considered as the embodiment of modern homogenized Japanese 'mainstream middle-class' identities, has arguably been critical in social identification and social inclusion. The relationship between housing, owner-occupier status and the self thus come to the fore in the post-war context within the specific terms of Japanese social relations. For Hirayama, those who owned their own homes could claim that they were part of society by owning housing. A house not only existed in a material sense, but also represented the social status and attitude of its owner. Home ownership represented a symbol of 'inside' - belonging to mainstream society (Hirayama, 2003a, 2003b). 


\section{Richard Ronald}

Clammer (1995) argues that identity and the individual in Japanese society cannot be understood in the same terms of the 'self' which have dominated western social theory (e.g. Giddens, 1991). Uchi and ie are more important to the self in this pattern of modernity. In a universe consisting of relationships, the focal point is the $i e$, as the ever contextualized $u c h i$. The Japanese self does not relate to the Japanese other as $I$ to $Y o u$, as one individual to another individual, but as a member of one group to a member of another group. Society is thus not opposed to the self but an extension of it, with $u c h i$ and $i e$ as the centre of social identification processes.

The house is normally associated with signifiers of household or individual status, and thus represents a social or status order reflecting social values and norms to which people allocate themselves and others (Williams, 1990). This is especially true in modern Japanese society where there has been a long debate concerning the nature of social stratification and class (Hashimoto, 2002). Traditionally a view of the Japanese as an amorphous, culturally homogenized group is a central characteristic of social, political and cultural discourses within and without Japan (Goodman and Refsing, 1992). The dominant perception is that Japan is classless or, at the very least, characterized by 'new middle mass' (Murakami, 1984) and is therefore not open to analysis on a social-class basis. Fukutake (1989) argues this is a consequence of the rise in income and consumption levels since the rapid economic growth of the 1950s.

For Clammer, modern Japanese class-consciousness has been primarily constructed around processes of consumption, seen as a continuous activity of self-construction or relationship maintenance and symbolic competition (1997: 101). A critical point is that consumption, which dominates individualistic possesses in western contexts, does not feed self-identity and a self-gratifying ego in the Japanese context, but provides a social nexus of signification where relationships between the self and others are defined. The self cannot consume alone, since consumption is to do with identity and solidarity and must as a consequence take place in the context of others (Clammer, 1995: 217). In this case class is no longer based on competition but rather solidarity communicated by consumption. Skov and Moeran (1995) also argue that, because of the deeply rooted ideology of homogeneity identifying Japanese society as a middle-class one, consumption differences more effectively structure the system rather than social-class fragmentations.

Many individuals consider themselves well off and socially undifferentiated from others in society. Indeed, by the 1980s between 80 per cent and 90 per cent of Japanese considered themselves middle-class. It has been argued that those who have seen themselves as working-class from the viewpoint of possession of assets and 'security of life' have stood in a subjectively perceptual duality as they normally define themselves within the middle stratum in terms of living standard (Murakami, 1984). It is arguably these conditions which have led to the 
predominant perception of Japanese society as a highly cohesive group where the massive majority are middle-class. Housing's social mainstream is thus strongly implicated in the definition and practice of class or status differentiation and central in the ideology of social and cultural homogeneity. Class and status are key elements of understanding both the cultural meaning of the home and its relationship to broader social hegemony and ideologies.

Home ownership as a signifier of status has been identified as more important in societies where other markers are absent (Adams, 1984). In Japan, however, owner-occupier identities are more critical in mediating a particular and complex structure of social stratification in which social differences are signified along with inclusiveness. The mainstream housing ladder provided the perception of a meritocratic and inclusive basis to status differences as one's situation on it was normally defined by position in the life-course. The existence of a clear hierarchy diffused the conflicts which inequalities generate, while at the same time the existence of a mainstream housing path signified inclusion into a middle-class identity.

In Ozaki's comparison (1998), whereas English homeowners explicitly connect housing and social status and acknowledge owner-occupation as a mechanism for status differentiation, Japanese resist class terms and judgements, despite clear distinctions between occupational groups and access to owner-occupied housing. She also identifies the resistance to definitions of Japanese society in class terms, although there is a clear awareness of differences in class and status as demonstrated by the investment of individuals in the task of maintaining or improving status. In Japan consequently, relative consumption levels and the subjective judgement of what is seen as an improved living standard does not necessarily support the total picture of a classless society (Ozaki, 1998: 63). Indeed, interview research with homeowners (Ronald, 2004b) uncovered some consensus concerning perceptions of home ownership as a necessary step in acquiring social standing, although such discourses are normally distanced from social class assertions and largely connect owner-occupiers to the kind of status necessary for credit with banks, or status as a reliable person in a community. Ozaki concludes that Japanese people do see differences within the so-called middle stratum - it is just that they do not want to speak about them (1998: 78).

In the Japanese post-war context a structured form of social inequality developed, with high-income groups being able to purchase homes and lower income groups being forced to rent (Miyake, 1980). Within the owner-occupied sector, the quality of estates and housing districts has also varied according to occupational and income. Consequently, Ozaki (1998) argues that while the debate on class and status has emphasized homogeneity, the structure of the housing market has resulted in clear and strong divides between income-groups stratified in the occupational hierarchy. The implication is that, despite the cultural assertion of homogeneity and middle-classness, which has been mediated by 


\section{Richard Ronald}

the post-war owner-occupation system, home ownership is one of the clearest markers of social differences and entrance into it is fundamental to asserting normalized social identities. Little has been done to allot housing resources to poorer households and those on low incomes, and public housing has increasingly been provided as a sector for the 'worthy poor' such as the elderly and those with special needs (see Hirayama, in this volume). This is largely down to the focus of government housing loan policy on middle-class borrowers and middle-class properties rather than more universal subsidization and policies such as 'right to buy'. Arguably, housing classes (see Rex and Moore, 1967; Saunders, 1978) were created in Japan, which reflect and strengthen what would be considered social class divisions. This is not to say that housing classes are more significant than social classes per se, but that in Japan, where social classes are not so clearly defined, it has greater impact on social inequalities.

The passiveness of civil society, which has facilitated the economic freedom and political authority of the state, can be accounted for by the degree of social harmony and consensus-forming activity present in Japanese social class relations. However, Sugimoto challenges the stereotype of Japan as a 'consensus' society, as consensus has a very different meaning in a country where the authoritarian basis of social control is so strong. He sees 'groupism', the characteristic form of Japanese collectivism, as merely an expression of an effective system of social control (1986: 67). Pressure to achieve consensus can result in the concealment of power relationships within and between groups rather than genuine participation in decision-making (Reich, 1983).

Despite collectivist currents, public welfare is rather undeveloped in Japan, which is contradictory to the logic of western theoretical understanding which has associated mass home ownership with individualistic societies and public renting with collectivistic social systems (Kemeny, 1992, 1995). Modern Japanese home ownership embodies many traditions of $i e$ as well as the modern ethos of economic growth and modernization and thus encapsulates both self-reliance and collectivism in terms of social and economic participation. Consequently, the Japanese state has been able to support communalistic ideologies without being responsible for social conditions directly. Citizenship has been mediated through the image of the family as a self-sufficient property-owning unit rather than through the establishment of universal citizenship rights.

Just as the Japanese manifestation of modern collectivism is divergent from western understandings, so is the mirror concept of privatism, especially in relation to the private realm of the home. Ozaki (2002) emphasizes the differences between the occidental concepts of individualism and privatism and the family centred, socially interdependent basis of Japanese privatism. She accounts for this in terms of the core cultural values of group-based identities in Japan. Home ownership, which is tacitly linked with privatism, independence, autonomy, freedom and 
individualism in western cultures, is thus manifested in more collective terms in modern Japanese private tenure relations.

In western societies, variable but notable public welfare systems emerged in the post-war period, which has been considered an inevitable development in late capitalism related to the maintenance of state legitimacy (Habermas, 1973). This is subsequently associated with de-commodification effects in society where the availability of public goods erodes market relations and dependency on waged employment. Japan, alternatively, developed a social system based on very limited social security and welfare spending (see Jones, 1993). Self-reliant families who have the security of valuable housing assets have been the basis of what Japanese governments have affirmed as the 'Japanese Style Welfare Society'. Despite attempts to improve welfare provision in the early 1970s under the Tanaka administration, by the late 1970s the government asserted the desire to build a welfare society based on 'retaining a traditional Japanese spirit of selfrespect and self-reliance, human relations and the traditional system of mutual assistance' (Prime Minister Ohira Masayoshi, speech to the National Diet, Jan. 1979). Japanese style welfare therefore has relied substantially on the family as a provider of security and social security as well as a mediator of care exchanges. The traditions of $i e$ have thus been drawn upon by the state which has transformed residual responsibilities associated with the traditionally ideology of the family in its own favour. The limited role of the state has been maintained by the family, seen as responsible for the welfare of its members, with the circulation of housing assets central in this process (Izuhara, 2000; Ronald, 2004a).

What is perhaps most peculiar to Japan among the older industrialized societies where owner-occupation is the dominant tenure is thus the significance of housing in welfare relationships. Economic growth and asset augmentation, necessary to support family-based welfare responsibilities, have been significant in the maintenance of state legitimacy and authority. As long as the economy appeared to expand and the state could come up with the goods in terms of socio-economic development, its legitimacy has remained largely unchallenged. The state has been let of the hook in terms of social welfare obligations to citizens. However, this situation has begun to unravel in the post-bubble environment.

\section{Beyond the bubble: fragmentation and deregulation}

In the modern Japanese context, while dwelling has become consumption and houses 'investment properties', the symbolic and material strength of the family within has been reinforced. Status, identity and intergenerational continuity associated with housing ensured that elements of traditional meanings of ie were integrated into the modern homeowner market. Moreover, asset-based family home ownership has facilitated social identification processes that have 


\section{Richard Ronald}

diminished class conflicts and disguised real inequalities. It has also structured these inequalities and reinforced the legitimacy of a state that has provided limited and inequitable welfare services. The ideology of the Japanese home is therefore central. The modern owner-occupied home has become a container of a unified and self-reliant family clearly identifiable within the parameters of homogenized social identities. While some elements of $i e$ have been eroded in the post-war period, it remains critical to social ideologies and relations.

However, the housing and social system has, in recent years, come under tremendous strain. Indeed, the implosion of the economic bubble at the end of the 1980s marked the beginning of a new period of social transition dominated by economic stagnation and uncertainty. Again, housing has been at the heart of social change. At the economic level land and housing markets have been in decline since the early 1990s. Indeed, values of housing bought during the height of the land price bubble have in many cases halved. The housing ladder, which was the basis for family asset accumulation and intergenerational exchanges as well as the normative basis for social participation and status differentiation, has been fundamentally challenged by socio-economic conditions. Nevertheless, the house and home continue to be the battleground of forces of tradition and change.

At the household level, declining fertility rates and societal ageing pose challenges to the maintenance of the social balance, and fragmentation and diversification of household types have become characteristic, and have eroded the primacy of social mainstream identification. The proportion of houses with a couple and children living together has decreased from 46.1 per cent in 1970 to 35.4 per cent in 1995, and the proportion of single households rose from 10.8 per cent in 1970 to 23.1 per cent in 1995 (Statistics Bureau, 2001). Indeed, individualized living practices and network-based mutual family relations have been emphasized in emerging household patterns (see Hinokidani, in this volume). In the broader context, growing unemployment and job insecurity, loss of faith in the government and institutional authorities, and the erosion of traditional social values have also challenged the consistency of Japanese modernity.

At the same time, some elements of the built environment have showed renewed vigour. While the overall housing market was in decline, construction of new apartments tripled between 1993 and 1999 (Ministry of Land, Infrastructure and Transportation, 2003). Tokyo in particular has seen numerous large-scale residential developments emerging across central urban zones (see Hirayama, in this volume). The state's response to a decade of economic stagnation was to reassert the project of modernization. This time it has adopted the language of global competition and urban renaissance policy has been used as a driving force for change (see Saito and Thornley, 2003). The type of households the Tokyo Metropolitan Government is seeking to attract and serve, for example, do not fit the traditional criteria of $i e$ and the social mainstream family. Specifically, urban renaissance policy related documents have engaged in discourses of 
individualism for the first time, where housing and urban conditions for people capable of competing in the global market are nurtured. The housing needs of the professional middle-class individuals are being focused upon in contemporary policy, while the needs of lower income families are neglected.

Deregulation and marketization have been the watchwords of twenty-firstcentury government. Housing has been a specific target. The state's central role in the housing system is being gradually dismantled and even more freedom is being given to the private sector. The Urban Development Corporation, which has been restructured into the Urban Regeneration Agency, no longer supports social rental housing projects and now plays only a limited role in housing provision. The Government Housing Loan Corporation is withdrawing from the primary market, leaving housing finance to the private sector (see Oizumi, in this volume). Essentially, the social mainstream family is no longer being supported by housing policy and households are expected to become even more self-reliant and economically self-sufficient.

There are numerous effects in housing relations at the household level signifying further shifts in the meaning and salience of $i e$ relations and the Japanese home. Research has demonstrated a growing cleavage in housing wealth and approaches to housing and the family between generations (Ronald, 2004b). Younger homeowners have become stoic about the vicissitudes of the property market and have developed a more pragmatic approach to the home as a centre of family continuity and intergenerational family assets. The assumption, demonstrated in interview discourses, is that future generations will have to be more geographically mobile and independent, making inheritance of family-owned land problematic. There are also fewer expectations of housing or wealth transfers in exchange for stronger family connections and reciprocal intergenerational care relations (2004b: 228-33). Older homeowners, however, are more attached to traditional ideologies concerning the essential nature of home ownership and the importance of family continuity and interdependency. Most of this generation were property owners during the 'golden era' of rapid house price inflation which may account for their commitment. Nevertheless, for most homeowners, young and old, there is a strong association of housing with a deeper discourse on the significance of owning land and property in Japan which is often connected to culture and tradition (Ronald, 2004b).

In comparative context the discourses expressed in the above research are congruent with discourses on housing in Anglo-Saxon societies where home ownership has been normalized as the majority tenure (Gurney, 1999). In these societies too owner-occupation has been integrated with essentialist discourses on natural predispositions and cultural tradition. What is unusual about the Japanese case is the pattern of reciprocal family relations implicit in housing discourses which reflect ie tradition in terms of a level of assumed continuity. That is not to say the family is not central in western housing discourses, but that in Japan the 


\section{Richard Ronald}

family and home, as a nodal point of relations between the self and society within the traditional Japanese social nexus, is pre-eminent. The practice and ideology of Japanese housing and dwelling, however, is showing signs of fragmentation in the current phase of social and economic transition, as demonstrated by cohort dissonance. The character of modernity in contemporary social change is arguably placing more pressure on traditional elements of $i e$ relations and ideologies, which have historically held together social hegemony and a sense of harmony and communality in Japanese social relations.

Daniels (2001) illustrates that contemporary families are far more fragmented than the ideals of ie and katei have asserted. Individuals within the household follow very separate lifestyles, largely differentiated by age and gender. As in individualist societies, the house as a 'collective good' for the family is diminished as technology has facilitated the fragmentation of the home (Douglas, 1991), as well as by spatial segregation facilitated by modern housing designs. Although much is made of family interaction and harmony in relation to relationships outside the household, the lives of household members are strongly differentiated. The synthesis of katei with ie in pre-war Japan formalized an ideal of family life and family unity, and Daniels suggests the idea of social harmony based on gendered, framed identities continues to be cherished. However, in practice social relationships in the home, as in wider society, are experiential and dynamic rather than static (Daniels, 2001: 225).

\section{Conclusions}

This chapter set out to demonstrate how housing and family dwelling has been a key point of interaction between tradition and social change in modern Japan. Indeed, Japanese culture has historically emphasized the house and home as a core of collective sociability, harmony and order, although it has also been critical to the structure of power and the maintenance of hierarchal relations. Contemporary international housing research has begun to engage with a greater level of social diversity concerning housing systems and to deal more concertedly with the interaction of social practices, identification processes and the communication of meanings in housing and the public and private sphere (Forrest and Lee, 2003; Clapham, 2005).

Japan has demonstrated one of the most radical forms of modernization and the family and built environment have been at the heart of transformation processes. At the same time, the focus in Japanese social life on the house and family in relation to the orientation of subjectivities, tradition and continuity have meant that it has been a fundamental arena for the dialectic interaction of the forces of conservatism and change, authoritarianism and democracy, tradition and modernity. Despite radical changes in the family, the organization of dwelling and housing units, the ideal and ideology of the house and home have mediated 
a sense of continuity and stability in social relations during radical periods. While contemporary urban environments and Japanese houses resemble nothing traditionally Japanese, they are the modern incarnations of $i e$ and the embodiment of Japanese life and cultural heritage. Indeed the house and family have been both containers of cultural integrity and engines of modernization.

This chapter has emphasized the unusual elements of Japanese homes and housing context as a way of establishing a framework for socio-cultural understanding. The pattern of modernity in Japan has many unique social elements and it is difficult to fit Japan into western housing models. However, many of the Tiger economies of East Asia have aped the policy structure and approach of the Japanese state to housing, families and household-based welfare. Indeed, while there has been an overemphasis in analyses of Japan on asserting uniqueness and incomparability, we should consider Japanese housing normatively. As in many western societies, Japan has experienced during modernization the embedding of home ownership and a normalized, consumption orientated, housing ladder in discourses and social practices. Housing policy has also been important in welfare relations and economic growth, and has been a basis for social stability and political legitimacy of the state, as it has in other industrialized societies. Housing in Japan has not legitimized the state through the ideology of 'property owning democracy', however, as is evident in western homeowner societies, but in terms of a less familiar model of family based housing consumption and asset augmentation (see Ronald and Hirayama, in this volume).

Japan demonstrates a rather extreme form of housing commodification with consumption central to social relations and identification processes that are shaped by culturally embedded features. This process started in the pre-war era, where the shape of the family was renegotiated and housing began to represent a commodity. In the initial post-war era housing became central in defining a new set of socio-cultural values, where middle-class and social mainstream identification were critical to social harmony. This also manifested itself physically in the form of homes and houses and the construction of towns, cities and communities. In the post-bubble environment, however, economic neo-liberalization and other forces of change are fragmenting households and undermining the homogeneity of families, lifestyles and aspirations which have been integral to the process of modernization. Whether or not the concept of $i e$ and the ideologies attached to home ownership consumption can stand up to new pressures is now in question.

\section{References}

Adams, J.S. (1984) The meaning of housing in America (Presidential Address), Annals of the Association of American Geographers, 74(4):515-526.

Befu, H. (1989) The emic-etic distinction and its significance for Japanese studies, in Y. Sugimoto and R.E. Mouer (eds) Constructs for Understanding Japan, New York: Kegan Paul International. 


\section{Richard Ronald}

Benedict, R. (1947) The Chrysanthemum and the Sword: Patterns of Japanese Culture, London: Secker \& Warburg.

Berger, P.L. (1979) Facing up to Modernity, Harmondsworth: Penguin Books.

Cannadine, D. (1983) The context, performance and meaning of ritual: The British monarchy and the 'invention of tradition', c.1820-1977, in E. Hobsbawm and T. Ranger (eds) The Invention of Tradition, Cambridge: Cambridge University Press.

Clammer, J. (1995) Difference and Modernity: Social Theory and Contemporary Japanese Society, New York and London: Kegan Paul International.

Clammer, J. (1997) Contemporary Urban Japan: A Sociology of Consumption, Oxford: Blackwell.

Clapham, D. (2005) The Meaning of Housing, Bristol: Policy Press.

Dale, P.N. (1986) The Myth of Japanese Uniqueness, London: Croom Helm and the Nissan Institute.

Daniels, I.M. (2001) The untidy Japanese house, in D. Miller (ed.) Home Possessions: Material Culture behind Closed Doors, Oxford: Berg.

Davidoff, L. and Hall, C. (1987) Family Fortunes, London: Hutchinson.

Doling, J. (1999) Housing policies and the little tigers: how do they compare with the other industrialized countries, Housing Studies, 14(2): 229-50.

Douglas, M. (1991) The idea of home: a kind of space, Social Research, 58(1): 289.

Dower, J.W. (1999) Embracing Defeat: Japan in the Wake of World War Two, New York: Norton.

Engel, H. (1964) The Japanese House, Rutland: Charles \& Tuttle.

Forrest, R. (2003) Some reflections on the housing question, in R. Forrest and J. Lee (eds) Housing and Social Change: East West Perspectives, London: Routledge.

Forrest, R. and Lee, J. (2003) Housing and Social Change: East West Perspectives, London: Routledge.

Forrest, R., Kennett, P. and Izuhara M. (2003) Home ownership and economic change in Japan, Housing Studies, 18(3): 277-93.

Fukutake, T. (1989) The Japanese Social Structure: Its Evolution in the Modern Century, Tokyo: University of Tokyo Press

Giddens, A. (1991) Modernity and Self Identity: Self and Society in the Late Modern Age, Stanford, CA: Stanford University Press.

Goodman, R. (1992) Ideology and practice in modern Japan, in R. Goodman and K. Refsing (eds) Ideology and Practice in Modern Japan, London and New York: Routledge.

Goodman, R. and Refsing, K. (eds) (1992) Ideology and Practice in Modern Japan, London: Routledge.

Gurney, C. (1999) Lowering the drawbridge: a case study of analogy and metaphor in the social construction of home ownership, Urban Studies, 36: 1705-22.

Habermas, J. (1973) Legitimation Crisis, Boston, MA: Beacon Press.

Hashimoto, K. (2002) Class Structure in Contemporary Japan, Melbourne: Trans Pacific Press.

Hayakawa, K. (1990) 'Japan', in W. Van Vliet (ed.) International Handbook of Housing Policies and Practices, Westport, CT: Greenwood Press.

Hein, C., Diefendorf, J.M. and Ishida, Y. (2003) Rebuilding Urban Japan After 1945, New York: Palgrave Macmillan.

Hendry, J. (1992) Individualism and individuality: entry into a social world, in R. Goodman and K. Refsing (eds) Ideology and Practice in Modern Japan, London and New York: Routledge. 
Hendry, J. (1995) Understanding Japanese Society, London: Routledge.

Hirayama, Y. (2003a) Home ownership in an unstable world: the case of Japan, in R. Forrest and J. Lee (eds) Housing and Social Change: East West Perspectives, London: Routledge.

Hirayama, Y. (2003b) Housing policy and social inequality in Japan, in M. Izuhara (ed.) Comparing Social Policies: Exploring New Perspectives in Britain and Japan, Bristol: Polity Press.

Hirayama, Y. and Hayakawa, K (1995) Home ownership and family wealth in Japan, in R. Forrest and A. Murie (eds) Housing and Family Wealth: Comparing International Perspectives, London: Routledge.

Izuhara, M. (2000) Housing and Family Change in Post-War Japanese Society: The Experiences of Older Women, Aldershot: Ashgate.

Jones, C. (1993) The Pacific challenge: Confucian welfare states, in C. Jones (ed.) New Perspectives on the Welfare State in Europe, London: Routledge.

Kemeny, J. (1992) Housing and Social Theory, London: Routledge.

Kemeny, J. (1995) From Public Housing to the Social Market: Rental Policy Strategies in Comparative Perspective, London: Routledge.

Koizumi, K. (1979) Kagu to Shitsunai Ishou no Bunka shi (A Cultural History of Furniture and Interior Design), Tokyo: Housei Daigaku Shuppan.

Koyano, W. (1996) Filial piety and intergenerational solidarity in Japan, Australian Journal on Ageing, 15(2): 51-6.

Mayokovich, M.K. (1978) The Japanese family, in M.S. Das and P.D. Bardis (eds) Family in Asia, New Delhi: Vickas Publishing House.

Merrett, S. (1982) Owner Occupation in Britain, London: Routledge \& Kegan Paul.

Ministry of Land, Infrastructure and Transport (2003) Tochi Hakusho (Government White Paper on Land), Tokyo: National Printing Bureau.

Miyake, J. (1980) Genzai no Mochi-ie Shiko ni tsuite (Current trends of home ownership), Kokumin Seikatsu Kenkyu (National Livelihood Studies), 19(4): 1-10.

Mizuoka, F. (2004) Japan: the economic consequences of the fetish of space, Urban Policy and Research, 22(1): 93-9.

Moeran, B. and Skov, L. (1997) Mount Fuji and the cherry blossoms: a view from afar, in P. Asquith and A. Kalland (eds) Japanese Images of Nature, Richmond, Surrey: Curzon Press.

Morishima, M. (1988) Confucianism as a basis for capitalism, in D.I. Okimoto and T.P. Rohlem (eds) Inside the Japanese System: Readings on Contemporary Society and Political Economy, Stanford, CA: Stanford University Press.

Murakami, Y. (1984) Shin Chukan Taishu No Jidai (Era of the New Middle Class), Tokyo: Chuo Koronsha.

Nagamine, H. (1986) The land readjustment techniques of Japan, Habitat International, 10(1/2): 51-8.

Nasu, S. and Yazawa, Y. (1973) Study on Support for the Aged, Tokyo: Kakiuchi Shuppan.

Nishikawa, Y. (1995) The changing form of dwellings and the establishment of Katei (home) in modern Japan, Nichibei Josei Jaanaru (US-Japanese Women's Journal), English Supplement, 8: 3-36.

Ochiai, E. (1997) The Japanese Family System, Tokyo: LTCB International Library Foundation.

Ozaki, R. (1998) Classlessness and status difference: the 'Tatemae' and 'Honne' of home ownership in Japan, Hitotsubashi Journal of Social Science, 30: 61-83. 


\section{Richard Ronald}

Ozaki, R. (2002) Housing as a reflection of culture: privatized living and privacy in England and Japan, Housing Studies, 17(2): 209-27.

Rapoport, A. (1981) Identity and environment: a cross cultural perspective, in S. Duncan (ed.) Housing and Identity: Cross-Cultural Perspectives, London: Croom Helm.

Reich, M.R. (1983) Environmental policy and Japanese society, International Journal of Environmental Studies, 20: 191-207.

Rex, J. and Moore, R. (1967) Race, Community and Conflict, Oxford: Oxford University Press.

Ronald, R. (2004a) Home ownership, ideology and diversity: re-evaluating concepts of housing ideology in the case of Japan, Housing, Theory and Society, 21(2): 49-64.

Ronald, R. (2004b) Japan as a homeowner society: the role of housing and home ownership ideology in Anglo-Saxon and Japanese contexts, Ph.D. thesis, Nottingham Trent University, UK.

Rybczynski, W. (1986) Home: A Short History of an Idea, London: Heinemann.

Saito, A. and Thornley, A. (2003) Shifts in Tokyo's world city status and the urban planning response, Urban Studies, 40(4): 665-85.

Sand, J. (1998) At home in the Meiji period, in S. Vlastos (ed.) Mirror of Modernity, Berkeley, CA: University of California Press.

Saunders, P. (1978) Domestic property and social class, International Journal of Urban and Regional Research, 2: 233-51.

Skov, L. and Moeran, B. (1995) Women Media and Consumption in Japan, Richmond, Surrey: Curzon Press.

Sorensen, A. (2002) The Making of Urban Japan, London: RoutledgeCurzon.

Statistics Bureau (Japan) (1986-2003) <http://www.stat.go.jp/english/>.

Sugimoto, Y. (1986) The manipulative basis of 'consensus' in Japan, in G. McCormack and Y. Sugimoto (eds) Democracy in Contemporary Japan, New York: M. E. Sharpe.

Waswo, A. (2002) Housing in Post-War Japan: A Social History, Richmond, Surrey: Curzon Press.

Watsuji, T. (1988) The family as an ethical system, in I. Okimoto and T.P. Rohlen (eds) Inside the Japanese System: Readings on Contemporary Society and Political Economy, Stanford, CA: Stanford University Press.

Williams, R. (1990) Culture and Society, London: Hogarth Press.

Yamada, Y. (1999) Affordability crisis in housing in Britain and Japan, Housing Studies, 14(1): 99-110. 


\title{
9 Situating the Japanese housing system
}

\author{
Richard Ronald and Yosuke Hirayama
}

\section{Introduction}

This book has explored key aspects of the housing system in Japan, identifying how they are deeply embedded socially and economically, and, moreover, bound up reciprocally with patterns and processes of social change in Japan's postwar era. While each chapter has focused on diverse policy elements, economic developments, social structures, family relations and household meanings and practices, a number of characteristics have consistently re-emerged in consideration of Japan's specific housing system pathway and social history. The tendency for family homes, property assets and housing policy to be increasingly central in the nature of social, political and economic transformations is strongly evident, especially in Japan's post-bubble environment. In this final chapter we begin by considering more explicitly the unifying forces and traits identified, which link the chapters of the book, in order to initiate some informed speculations on the role of housing and the nature of socio-economic transformations.

In the second part of the chapter we address the comparative importance of housing and the manifestation of forces for convergence and divergence between societies in an increasingly neo-liberalized global context. We consider the broader picture in terms of how the Japanese system may be interacting with forces of globalization, which may lead to greater differentiation between Japan's social structure and housing system, and other societies. We also attempt to identify, or situate, Japanese society and its housing system within the frameworks and models established in the western literature. Japan's housing, economic and social systems stand out somewhat against the normative background formed from studies of housing and societies in western contexts, and our analysis illustrates how housing practices and policies influence, and are influenced by, broader transformations. We assert the relative salience of a Tiger, or East Asian, housing system model by identifying convergent systems aspects across the region. The main convergent element in a globalized context seems to be greater individual 
risk and enhanced household vulnerability to global economic fluctuations, and the main divergent element is how each society reacts.

\section{Transitions in the Japanese housing system}

It is useful to begin by summarizing the main elements in the development of the Japanese housing system. In the immediate post-war period the Japanese housing system was developed in order to cope with a serious housing shortage, particularly in the war-devastated cities. People were living in poor and miserable conditions and were in desperate need of shelter. In addition, the tremendous speed of urbanization as well as the rapid increase in the number of households put stress on the demand for dwellings. In response to the crisis situation caused by housing shortage, the government systematized housing policy measures in the 1950s in order to promote the mass production of dwellings and housing related industries began to develop in the 1960s. Associated with vigorous economic development, housing construction expanded at a striking pace and consequently the quantitative housing problem was largely mitigated by the 1980s. Although the qualitative aspects of housing problems such as overcrowding and lack of basic amenities have been highlighted since the 1970s, the provision of quality housing has steadily increased, which encouraged a decrease in the ratio of substandard housing to less than 10 per cent by the 1990s. Taking the extremely poor conditions of housing immediately after the war into consideration, it is reasonable to presume that the post-war housing system has operated relatively successfully in terms of providing people with respectable dwellings.

The role of housing in post-war Japan's development cannot and should not be addressed only within the context of housing provision itself. The housing system, which has particularly focused on the mass construction of housing and the promotion of middle-class home ownership, has been deeply embedded in the formation of post-war social and economic orders. High-speed economic development nurtured the middle classes and in turn the increased acquisition of owner-occupied housing further accelerated economic growth. It was assumed that the majority of people could lead a standardized life-course by climbing up socio-economic and housing ladders to become a homeowner, and that the promotion of home ownership had a stabilizing effect on social organization. As the prices of land and housing rose dramatically, owning a house meant that the owners could realize considerable capital gains. The post-war housing system was thus characterized by the interconnection of: high-speed economic development; large-scale housing construction; the expansion of middle-class home ownership; the accumulation of capital gain based housing assets; and social stability centring around property-owning middle-class families.

The government operated housing policy measures to allot the largest part of public funds to families with middle incomes and to encourage them to purchase 
or build their own housing. It was apparent that the priority was the formation of a social mainstream by means of middle-class home ownership promotion, with the intention of supporting economic development and social cohesion (Hirayama, 2003). Of housing policy measures, the expansion of low-interest mortgages by the Government Housing Loan Corporation was emphasized in particular, while the direct provision of public rental housing was marginalized. In post-war Japan, where the government put explicit priority on economic prosperity, the concept of universal social rights to housing was never adopted, as was reflected in the nature of low-income housing policy. The promotion of home ownership was also assumed to play a part in forming political stability. The conservative government led by the LDP (Liberal Democratic Party) facilitated the mass construction of owner-occupied housing in order to obtain political support from the construction, housing and real estate industries, and regarded the promotion of middle-class home ownership as an effective means of maintaining the property ownership based social core of political order.

The last decade of the last century, or Japan's 'lost decade', marked the period in which Japan's social, demographic, economic and institutional systems began to restructure fundamentally. As the chapters of this volume have demonstrated, over the years the reshaping of the housing system has reflected and accelerated social transformations. We should now turn attention to cross-chapter convergence in addressing the understanding of the interconnection of housing and social change in contemporary Japan. Obviously, there have appeared new ways in which the housing system has become embedded in social transformation.

First, the emergence of a more volatile, uncertain economy has inevitably impacted on the reorganization of the housing system. Since the bursting of the bubble economy at the beginning of the 1990s, associated with a long, deep recession, the prices of land and housing have dropped sharply for the first time since the war. Since the Japanese home ownership system was closely implicated with the capital gain based economy, a swell in capital losses of residential property eroded the traditional mechanisms of home ownership promotion. Households who purchased housing during the bubble period are now suffering negative equity and the burden of mortgage repayment for properties that are declining in value. As Hirayama's chapter stressed, Japan as a 'homeowner society' has begun to experience a new phase where home ownership can no longer promise security in terms of asset augmentation, and the conventional housing ladder system is no longer necessarily expected to maintain its effectiveness.

Housing and home ownership became increasingly central to the maintenance of social stability in the post-war period and the meanings attached to the family home were transformed to reinforce patterns of social formation and reinforce the sense of stability during periods of rapid social and economic change. The relationship between housing, stability and social identification in Japan was highlighted in the chapter by Ronald, which illustrated the dynamic role of 
housing tradition and practices in the Japanese context. Social fragmentation and the erosion of economic stability have undermined the sense of security and continuity associated with home ownership, which has exacerbated social conditions and the viability of housing practices established before the 1990s.

A factor which supported high-speed economic growth was the sustained development of the housing and construction industries. Mass demand for dwellings was generated continuously by the system of 'scrap and build' as well as by sustained urbanization and the increasing number of households, which formed a relatively non-competitive business environment for the housing related industries. Reliance on the construction sector was a key feature for post-war governments in pursuing economic growth. As Oizumi demonstrated, however, the housing industry is no exception, and has suffered extensively from the postbubble recession. Businesses related to housing construction have become unstable and are now experiencing a more competitive environment resulting in hardship, particularly among small-sized house-building companies. While the 'scrap and build' system is now severely criticized in terms of environmental sustainability and waste related issues, the housing and construction sectors are increasingly pressing the government to maintain demand for house building.

Second, the magnitude of demographic change should be highlighted in understanding the transitional condition of the Japanese housing system. The most important element of transformation, demographically, is the substantial and rapid decrease in the total population. It is forecasted by the National Institute of Population and Social Security Research that the population for the whole nation will drop from 128 million in 2005 to 118 million in 2030, and then to 101 million in 2050. One implication is that the maintenance of large-scale housing construction will become next to impossible due to an unavoidable decline in demand for housing. This will inevitably encourage the reorganization of the housing industry and the construction based economic development system. Moreover, in Japan the speed of social ageing is the highest and the fertility rate is one of the lowest in the world. Although the government has launched a series of policy measures to encourage the fertility rate to increase, its sustainability remains to be seen.

The chapters by Hirayama and Izuhara looked at the role of the baby-boomer generation in transforming housing conditions. The trajectory of this cohort has been central to the shape of contemporary relations, and drove the socioeconomic development of post-war Japan. Baby-boomer households climbed up the housing ladder relatively smoothly, along with high-speed economic growth, and essentially triggered the rapid rise in house prices of the bubble era. This large cohort is now approaching their old age and it is presumed they will instigate new trends in society and the housing system in the near future. Izuhara gave a detailed examination of a new policy concern in the 'ageing society', that is, the turning of housing stock into cash flow. Many households belonging to the baby-boomer 
generation own their own housing and have considerably valuable property assets. Within the context of social ageing and augmented housing wealth, as well as a more volatile economy, the government has begun to examine the implementation of new policy measures by which the conversion of housing stock into cash flow is expected to stimulate the economy and restructure the economic conditions of 'asset-rich, cash-poor' older people. According to the analysis, however, it is likely that the idea of asset-based social policy will not necessarily produce the expected consequences.

Third, the structure of social inequality relating to housing has been reshaped since the beginning of the 'lost decade'. The post-war housing system, which was explicitly biased towards the promotion of home ownership, particularly for middle-class households, generated a large disparity between those with low incomes and those with higher incomes, between singles and family households, and between renters and homeowners. However, as long as the economy developed and households climbed up the socio-economic and housing ladders, the 'feeling of middle-classness' encompassed the broader part of society, and low-income, young renters, who had prospects of becoming middle-class homeowners, tended to regard themselves as members of the middle class. In this context, the home ownership oriented housing system effectively manipulated social inequalities (see Hirayama's chapter). Over the last decade, the diversification of household formation and the prolonged recession have made it increasingly difficult to conceal social inequalities. An emerging new structure of inequalities is characterized by complexity and instability, with various determinants including employment and income stability, household type, the timing of house purchase and the balance of asset and debt.

Hinokidani's chapter explored the role of family changes and gender as an increasingly important parameter in the formation of housing inequalities. While the post-war housing system was organized around the 'standard family' or 'male bread winner' model, there has been a tendency for single women and lone mother households to increase. Female-headed households outside of the 'standard family' model have been placed at a disadvantage in both the housing and labour markets. Since the middle of the 'lost decade', the numbers of homeless people have increased at the very bottom of society, representing profound transformations in the socio-economic structures of contemporary Japan. 'Social exclusion' is a relatively new concept in Japan, and policies have yet to thoroughly explore or address socio-economic restructuring. As Iwata's chapter demonstrated, with theoretical and evidence-based analysis, homelessness should not be understood as a mere extremity of traditional poverty within the framework of social inequality, but is a particular form of social exclusion.

Fourth, the government has geared its housing policy towards expanding the role of the deregulated market in providing and financing housing, which has accelerated the fundamental restructuring of the housing system (see chapters 
by Hirayama, Oizumi and Sato). The most significant change in terms of the organization of the government's housing policy is the projected abolition of Government Housing Loan Corporation that has been the very central pillar of the home ownership oriented housing system. As regards to low-income housing policy, public rental housing provision will undoubtedly be further residualized. The legal system of tenant protection has also been deregulated, which has inevitably led to less secure tenure for tenants, particularly among low-income groups (see Sato's chapter). Since the bursting of the bubble, the financial deterioration of the government sector, which has reached or exceeded crisis level, has eroded the fiscal basis of conventional housing policy measures. In the context of the stagnant economic situation, as well as the forecasted decline in demand for housing, the business world, particularly the housing, construction and banking sectors, has strongly pressed the government to retreat from the provision of housing and mortgages in order to reduce government competition with private businesses. The consequences of the change in the basic direction of housing policy can already be seen. As Oizumi's chapter stressed, the privatizing of mortgage supply is likely to undermine access to home ownership, especially for households with low financial credibility.

The chapter by Sato highlighted the role of the 'company society', where the lifelong employment and seniority systems and the provision of a variety of employee benefits were regarded as the norm, and were key elements in reinforcing the housing system. It has been a feature of the Japanese system of housing provision that large corporations have provided their employees with company housing, rental subsidies and mortgages for house purchases. During the long recession in the 1990s, however, an increasing number of corporations began to retreat from their in-house housing systems, which paralleled government policies aimed at forming a more liberalized housing market.

Indeed, the system of housing provision in Japan has been in a new stage of transition since the 1990s. The changes in the housing system have reflected and reinforced the shifts in Japan from an industrialized, Fordist and Keynesian country to a post-industrialized, post-Fordist and more liberalized country. The post-war traditional system of housing provision has already been broken up and the future shape of the housing system is unpredictable. However, it is most probable that a more volatile economy and a more greatly differentiated society will increasingly interact with a more market oriented housing policy. What is certain is that housing will continue to play a significant role as a catalyst for socio-economic transformation.

\section{The Japanese system in a globalized world}

So far we have considered the nature of transformations in Japan and the salience of housing in Japan's future. How does the case of Japan prove illustrative of more 
universal processes and relations between housing, society and socio-economic development more globally? We now consider, more broadly, some of Japan's social, political and economic features in terms of how they have been facilitating a particular shape of social transformation. Specifically, we consider the particular brand of Japanese capitalism and how the approach of the state has mediated globalizing forces, as well as the impact of increasing individual risk brought on by social and economic change. In the following section we return to the role of housing and how the Japanese system can be located or conceptualized within a comparative framework.

In debates on the role and effect of globalization, on one side there have been assertions that advanced industrialized societies are becoming more integrated economically, and convergent in terms of institutional practices and structural processes. Indeed, Japan demonstrates many hallmarks of convergence with globalized social and economic trends: increasing deregulation and marketization, residualisation of social provision, social fragmentation and the breakdown of traditional institutions and values. Within each chapter we have demonstrated different aspects of these trends in the housing system. Nevertheless, as we shall consider shortly, Japan fits poorly with western system models and development pathways. Critically, there are a number of reasons to expect that while Japan becomes increasingly intertwined with networks of global capital and multinational corporate control, local systems and practices will become even more differentiated from other industrialized societies.

The Japanese approach to policy, planning and production that stimulated the unprecedented speed and level of growth make it stand out amongst industrialized nations. The Japanese 'miracle' has been explained in terms of political economy by many analysts. For Johnson (1982) the Japanese state has played a central role in prioritizing economic goals based on a strong consensus with industry. $\mathrm{He}$ refers to this kind of approach as the 'developmental state'. Schaede and Grimes (2003) refer to 'economic nationalism' in describing the mutual coordination of policy and markets between government ministries and industrial sectors. Henderson and Appelbaum (1992) classify Japan as a 'plan rational' country as the state sets national goals, intervenes in order to direct the economy as a whole and regulates constituent sectors. The pattern of economic and political control of internal interests is described by Schaede and Grimes in terms of 'permeable insulation' in that the response to global and local challenges is neither one of retreat or denial, nor one of full acceptance of global standards and practices. It 'permits entry and market competition in areas where that is the best approach for existing market players, while protecting (or allowing self-protection) in less competitive sectors' (2003: 244).

In the developmental or plan rational state bureaucrats and political leaders are compelled to get on and organize growth using whatever methods are to hand. Japanese capitalism can thus be characterized as non-liberal as the state plays 


\section{Richard Ronald and Yosuke Hirayama}

a key role in managing competition and guiding markets, but where corporate concerns trump political ones. Jones (1993) suggests that Japan differs from liberal regimes in terms of central direction and the sense of individual rights. It is not conservative corporatist or social democratic, following Esping-Andersen's categories (1990), as there is no incorporation of the interests of the working classes, and as such it is conservative corporatist without worker participation, laissez-faire but not liberal.

Essentially, Japan has resisted global rules for its domestic markets and has attempted to manage globalization by controlling both the speed and reach with which global rules and markets affect domestic players (Schaede and Grimes, 2003: p. xi). Since the 1990s the Japanese government has had to respond to new economic realities and domestic stagnation, and while there has been substantial pressure for deregulation of protectionist policies, there has been a concerted attempt by some elements of government to shield Japanese companies from global competition and the full vigour of market forces. Critically, while policy changes have focused on greater marketization, liberalization has not led to convergence with the Anglo-American model of minimally regulated markets. The nature of change and reform in Japan, and whether this change follows a neoliberal agenda, is difficult to untangle.

When considering social change in Japan it is necessary to retain an appreciation that capitalism, production and consumption have not been normalized by globalizing forces, and thus Japan does not respond to external forces in ways its position in the global economy would imply.

The ubiquity of government intervention, of industry associations as drivers of sectoral policy, and of corporate governance for the benefit of the management rather than shareholders, mean that Japan's response to the generic pressures of globalization remains distinctive.

(Schaede and Grimes, 2003: 254)

This is not to say Japanese capitalism is unique, or that it contrasts with a single type of normal capitalism or modernity. What is important is that the case of Japan illustrates diversity in practices of capitalism and processes of modernization that are shaping social transformations in the era of intensified globalization and network enterprise. The pattern of social modernization illustrates the dichotomy between the two forces. On the one side there have been calls for more discipline and assertion of traditional values, while on the other there has been a demand for reform and institutional change more fitting with global economic demands. The dynamics of these two forces are particularly evident in the government, which has been trying to adjust to the post-bubble landscape. The Koizumi administrative era, with prime-ministerial conflicts with his own party, epitomized this contradiction within Japan's ruling elite. 
The redistribution of risk from institutions to individuals can also be considered a main feature of global convergence. Strong globalization theorists perceive individuals as actors in markets whose actions are structurally determined, which is consistent with methodological individualism where individuals are considered able to objectively assess the level of risk inherent in competing courses of action. However, individual risk perspectives are mediated by social norms of what 'risk' is, and, in Japan, features and perceptions of risk and social inequalities have taken on a particular form.

Clammer argues that individualization and the set of subjectivities associated with western modernity that are related to the management of risk have not developed in Japan (1995). Furthermore, models of 'risk society' (Giddens, 1991; Beck, 1992) exclude sociological responses to risks involving community solidarity, networks of cooperation and self-help, and political and economic management of such risks by states, companies and institutions, which are, while under attack by neo-liberal forces, fundamentally evident in Japan. At the same time, while unemployment, exclusion from the housing system and even homelessness are increasingly manifest, few mechanisms have been developed to deal with the individualization of risk outside traditional social structures, company society and family based welfare provision. Essentially, risks are being increasingly felt in Japanese society, largely as a result of the long-term recession and its knock-on effects on labour and housing markets, but are being negotiated within a social framework that strongly resists individuation and risk, and where institutional and individual responses to risk are less predictable.

Clearly, indigenous aspects and processes have had a critical effect on how globalization has influenced Japanese society. Housing and home ownership sectors, which structure relationships between macro social and economic factors, and micro household relations, are mediated by elements that remain substantially localized. Housing can thus be considered a central node between universal and local processes of change and consolidation. While growing residualization of social housing provision and the growth of home ownership are universal trends across advanced industrial economies, these trends are having differentiated effects in each context. Indeed, housing has constrained the homogenizing effects of globalization. Due to its embeddedness, the housing system is likely to be central in facilitating the process of diversification.

\section{Contextualizing the Japanese housing system}

We now address, explicitly, how the Japanese housing system can be integrated, or not, with established models of housing and society. We draw upon both established modes of understanding developed from empirical European and North American cases, as well as emerging understandings of convergent patterns and radical differences among the group of East Asian societies, or Tiger economies, which 


\section{Richard Ronald and Yosuke Hirayama}

have demonstrated many similar approaches to housing, governance, citizenship and family asset building to the 'Big Tiger' - Japan. Numerous scholars have debated ad nauseam about the nature and impact of growing global integration, both culturally and economically, in which the Japanese case provides some unique insights on the influence of housing as an integral part of state, corporate, family and individual interests which mediates the influence of the global and local.

Since the 1960s housing has been increasingly seen as a central element in social divisions and the structure of social and economic systems across western societies (see Rex and Moore, 1967; Kemeny, 1992). A number of models have been asserted, accounting for different tenure patterns across industrialized societies as a way of compressing the evidence and providing a more holistic approach to understanding relationships between variables in various social conditions. However, Japan, as an established industrialized country within an East Asian regional nexus and a Shinto-Confucian-Buddhist cultural tradition, has been fundamentally problematic to categorize or fit within established comparative housing models.

Some authors have attempted to fit Japanese housing policies with European housing and policy regimes, which neglects key differences in interrelationships between housing, employment and welfare, as well as the impact of social class alliances, that are fundamental to housing systems and welfare capitalist regimes (see Esping-Andersen, 1996; Doling and Ford, 2003). Other approaches have drawn comparisons with America as post-war policies were initially set down by occupying American forces which attempted to establish a strong hegemonic model for economic development and market-driven liberalism. While Japan focused on economic expansion, established a strong corporate sector and emphasized private property rights, private consumption and home ownership, its brand of capitalism and social policy followed an indigenous logic and strayed wildly from recognizably western patterns. Essentially, Japan fits western typologies, categories and assumptions very poorly. The housing system is an exemplary case.

In terms of housing, Donnison and Ungerson (1982) distinguish between countries with, first, institutional or comprehensive policies, and, secondly, those with residual or social ones. In the former governments take responsibility for housing its population and housing is seen as a productive sector of the economy. In the latter governments only intervene in a residual way to support those whose needs are not met by the market. Japan demonstrates aspects of both. In national plans the Japanese approach has often been comprehensive, taking an overall view of housing needs, especially in the period of housing shortage, and housing has been seen as an economically productive sector. However, in terms of access, market forces have been central with increasingly residualized public housing provision and subsidies directed at stimulating middle-class home purchases. 
Kemeny's model of housing and society $(1992,1995)$, which emphasizes the role of tenure, also struggles to capture the character of the Japanese housing system. He differentiates between individualistic, home ownership dominated systems where public rental housing is residualized and effectively a separate category from the 'normal' housing market (dualist type), and collectivistic, rental dominated societies where public and private renting compete and the state can maintain substantial control over the housing market (unitary). Critically, Japan, which has been dominated by the policy and principles of self-reliant, family based owner-occupation, fails to meet the individualistic criterion and demonstrates more socially inclusive and collectivistic values. Japanese and Confucian values ostensibly contradict the association of housing consumption with an individualistic ethos, as it is the self-contained household itself which structures social relations and community responsibilities (see Ronald's chapter). At the same time, structures of public provision, associated with more collectivistic regimes, have been largely underdeveloped and households have been left with comparatively few social security safety nets beyond household savings and assets, and family support.

In light of the institutional system of housing, as Sato's chapter demonstrated, while the Japanese housing system partly fitted into the dualist model in terms of the explicit social division of the owner-occupied sector and the residualized public housing sector, it differed from the model due to the considerably large-scale provision of employee housing and other employee benefits relating to housing. The formation of the company society has been a critical element marking the difference between Japan and other industrialized societies.

What is perhaps more insightful in the Japanese case is the connection Kemeny makes between home ownership and welfare systems. The principle of allocation of housing is essentially based on ability of households to pay rather than principles of fairness and equity. Housing, social policy and welfare are not structured around universal citizenship rights and do not decommodify social relations as much as in European societies. It thus seems that while Japan appears more collectivistic and less individualistic, principles of markets and individual consumption still apply, and are in part structured by owner-occupied housing consumption, which acts as the basis for family asset accumulation, welfare exchange and reciprocal obligation.

\section{East Asian housing systems and welfare regimes}

Despite some similarities in the commodified nature of private housing and the residualized nature of public housing, it is not particularly useful to attempt to push the square peg of Japan into the round holes of western regime and policy typologies. In recent decades, however, along with the industrialization and development of the Little Tiger economies in the East Asia region (including Singapore, Hong Kong, 
Taiwan and South Korea), models of a Tiger regime type or an East Asian policy or welfare approach have emerged, which to greater or lesser extents also account for patterns of socio-political development in housing and social policy in Japan. Indeed, there has been a growing consensus in social policy discourse that East Asian experiences are distinctive from Euro-American models (Kwon, 1998), but there is no agreement on the precise nature of East Asian exceptionalism. There are concepts of 'Oikonomic welfare states' or 'Confucian welfare states' (Jones, 1993), and 'Japan-focused East Asian welfare regimes' (Goodman and Peng, 1996). The causes of East Asian exceptionalism have often been conceived in terms of culture or the role of the state, which are arguably inadequate in capturing the character of social policy approaches in the region (White and Goodman, 1998; Holliday, 2000) that demonstrate substantial within group variation. The key aspects of East Asian social policy are that, first, it has been primarily driven by the requirements and outcomes of economic development policy, and secondly, the role of the family features prominently in social policy and welfare arrangements.

For Wade these societies have been economically successful because of the 'government market' in which the state takes a major role in ensuring specific industrial sectors have developed in ways consistent with perceptions of national interests (1990: 27). Japan, in this case, has been a model of government-business cooperation. This relationship developed before 1945 and also underpinned rapid post-war economic development (Morishima, 1982). Essentially, Japan and the Little Tigers all demonstrate elements, to greater or lesser extents, of a specific type of corporatism that strongly links corporate objectives with social policy. This relationship is particularly tight in the case of housing policy.

Holliday's (2000) model of a 'productivist world of welfare capitalism' attempts to situate the East Asian group of Tigers as a recognizable and independent category within Esping-Andersen's conceptualization of capitalist welfare regimes (1990). In the productivist world social policy is strictly subordinate to the overriding policy objective of economic growth. Everything else flows from this: minimal social rights with extensions linked to productive activity, reinforcement of the position of the productive elements in society, and state-market-family relationships directed towards growth (Holliday, 2000: 708).

The principle of a Confucian, productivist or East Asian policy regime works as a unifying concept to the extent that these societies demonstrate a shared state paternalism and top-down processes of economic prioritization, with the government taking a considered and active role in guiding markets. However, to argue that they have a shared social structure, policy system, housing culture and value system is misleading. There is considerable variety in the state-market mix and the point at which the state intervenes. If a distinctive regime type exists, it is one that facilitates the manifestation of a range of policy systems, as there is significant within-group variation. For example, at one level a division can be made between one group of societies, including Japan, South Korea and Taiwan, 
characterized by low social welfare spending (in relation to GDP), and a second, including Singapore and Hong Kong, with a substantially higher degree of spending and state control. Deyo (1992) attributes this to degrees of urbanization and corresponding differences in the need for government provision of social services. This is evident particularly in the state involvement in the public housing sector in Hong Kong and Singapore.

Doling (2002) demonstrates how the nature of this divergence between the two groups has influenced the development of housing systems. Singapore and Hong Kong have experienced strong state control over land and high levels of state provision. Public housing has come to dominate both systems although in Singapore public provision has consistently focused on family home ownership through the public leasehold of owner occupied housing units, where the state holds a market monopoly, essentially controls land transactions and finances loans through state-managed compulsory savings. In the 1980s Hong Kong shifted its policy focus towards owner-occupation with the sell-off of public rental housing units and increased subsidy to serve the interests of expanding levels of home ownership, although considerable support of the public rental sector continues in many respects. Japan, Taiwan and Korea have had weaker controls and more selective state intervention, with subsidy being used to ensure that the housing needs of low-income groups are met within a market framework. Key differences thus exist in state-market and private-collective dimensions in housing policy and provision. Doling develops a typology of systems within this region (2002). One category emphasizes 'State Provision', and includes Hong Kong and Singapore. Another category features 'Selective Intervention' and is followed by Japan, Korea and Taiwan.

Housing is central to, and illustrative of, approaches to socio-economic development and policy in these societies, and there are a number of key similarities in housing regimes and household practices, even though the built environment, housing policies and value systems vary radically. For Doling (1999) it is the pattern of 'housing provision chains' that unifies Tiger societies as an ideal-type and differentiates them from western types. In each stage of the development, construction, and consumption chain, the relationship between state and market has a substantial effect. In the Tiger societies the state asserts itself at the developmental stage with highly directive five-year plans and state control over the economy affecting speed, location and nature of development. Construction is carried out by private companies and housing sold as a market good in terms of ability to pay. Doling thus asserts that East Asian housing policy regimes appear to constitute a distinct type.

Japan is strongly convergent with this type as the state strongly intervenes in the housing system (most directly in terms of the Government Housing Loan Corporation, but also through the Urban Redevelopment Agency, etc.), but with principles of family based consumption and household asset reliance at the heart 
of housing and broader social relations. While state policy and institutional support is fundamental to the housing system, the house still represents a family object that is consumed and regulated in a market, and not as a public good. Doling identifies two other types of chain in industrialized societies. One is the Liberal type, in which markets rule at each stage largely unfettered by the state. Housing is seen as a private good and sold or leased on the ability to pay. This type essentially reflects the qualities of an Anglo-Saxon model. The other is the Mainland European type, where the development stage is strongly determined by the state, but construction is carried out by the private sector. At the end, allocation and pricing are institutionally regulated by principles of need and fairness

While Doling identifies unifying elements within ostensibly diverse housing systems in East Asia, it is also important to note the significant relationship between housing, the social system and social control in these societies, which is very different from patterns identifiable in the West. In Japan housing can be seen to contribute to state legitimacy in three important ways. First, construction and housing consumption have driven economic growth with knock-on effects in other sectors. Economic growth has been the basis of the legitimation of the state, which is paternalistic, subtly authoritarian and dominated by a single party (the Liberal Democratic Party). Secondly, housing has been the basis of family security, and as long as the state has provided adequate means for middle-class access to privately owned housing, families have largely taken on themselves substantial responsibilities to provide for retirement, family welfare and social security. Privately owned housing assets have become central to individual retirement provision and welfare strategies and the state remains far less accountable than in other advanced societies. Thirdly, owner-occupation has provided a central means of identification for the social mainstream and middle-class lifestyles, which has supported the formation of hegemony uncritical of the capitalistic state. Similar sets of relations are apparent across East Asian societies and similar approaches to housing have been identified (see Lee, 1999; Chua, 1997).

In western societies housing policy has been seen to support social relations and the legitimacy of the state in very different ways. Crudely speaking, in societies where social rights are stronger and the influence of social alliances on the left have been more successful, demands for social rental housing have led to greater state provision and market involvement, and a larger proportion of quality rental housing distributed on principles of equity and fairness. Sweden and the Netherlands are often cited as typical examples of this approach, in which state support of the social rental sector is perceived to mutually reinforce sociodemocratic hegemony. Alternatively, in more market-liberal societies, principles of 'property owning democracy' have been more important to the legitimacy of governments who have pursued neo-liberal agendas. The principle is the shift of focus on citizenship rights from universal social rights to ones based on property ownership, where the expansion of owner-occupation is conceived to enhance 
citizenship and market-liberal hegemony. Britain, Australia and America are more typical of this approach.

Japan, along with the other Tigers, thus not only demonstrates divergence from western modes in its housing system and provision chains, but also in the set of social and political relations which link state authority to housing policy. Housing also, therefore, provides an insight to the nature of East Asian or productivist welfare regimes that accounts for the success of soft authoritarian regimes that have provided minimal social rights, but have sought to ensure economic growth which has, for the most part, facilitated welfare resources for households via owner-occupied housing assets. In recent decades, global economic fluctuations have led to greater volatility in international housing markets, which has been felt in the East Asian region (specifically in the aftermath of the 1997 Asian currency crisis). As families rely on their housing assets as the basis of welfare and security, with little recourse to other state services, there is much greater vulnerability to the vicissitudes of global markets.

\section{Conclusions}

It has become increasingly clear that housing in Japan, along with other social institutions and practices, has entered a new phase of change dominated by greater insecurity and competitiveness. At a broader level, transformations in sociodemographic constitution and relations, business and employment practices, and institutional structures of welfare and support are having fundamental impacts in Japan, which, although apparent across a number of industrialized societies, are more strongly felt in Japan. How these factors interact and resolve themselves in the coming years will be particularly insightful for other societies dealing with these changes at a more gradual speed. However, they will also reflect the peculiar social, economic and political make-up of Japan, which must be understood in terms of its own path and pattern of modernization and global integration.

In the case of Japan some specific economic, political and social factors will have particular salience in the next decades. Economically, Japan has become extensively integrated into the East Asian economy in the last decade, and has shifted production facilities and substantial amounts of investment into the region. Economic sustainability in Japan is consequently now bound more strongly to the stability and growth of China and East Asia, as well as emerging patterns of economic fluctuation and competition locally and globally.

Politically, Japan's current administration has demonstrated a commitment to structural deregulation and neo-liberal practices. Within political, administrative and business elites, neo-liberalizers are in conflict with conservative elements who seek to protect the integrity of Japanese systems and markets as well as traditional (and sometimes nationalistic) values. This conflict is unfolding in a climate of 


\section{Richard Ronald and Yosuke Hirayama}

growing political aggravation in the region involving Japan, South Korea, North Korea and China.

Socially, as we have examined, Japan is in a process of realignment and fragmentation, which is exacerbated by the breakdown of 'company society', the impact of the baby-boomer generation, diversification of the family and lifepaths, and growing anomie and frustration among younger generations who find traditional values and expectations alien to their experiences of employment, society and family life. Increasingly, life in Japan is dominated by feelings and experiences of insecurity and risk.

Housing is an embedded social, economic and political element, and has been at the heart of processes of transformation. Housing will take on an even more prominent role in a world where macro economic changes are increasingly distributed to individuals and households whose security and welfare reside in the stability and prosperity of housing property assets. At the same time, access to housing assets and disparities in the market will increasingly exaggerate the manifestation of social inequalities and feelings of exclusion.

\section{References}

Beck, U. (1992) Risk Society, London: Sage Publications.

Chua, B.H. (1997) Political Legitimacy and Housing: Stakeholding in Singapore, London: Routledge.

Clammer, J. (1995) Difference and Modernity: Social Theory and Contemporary Japanese Society, New York and London: Kegan Paul International.

Deyo, F.C. (1992) The political economy in social policy formation: East Asia's newly industrialized countries, in R.P. Appelbaum and J. Henderson (eds) States and Development in the Asia Pacific Rim, Newbury Park, CA: Sage.

Doling, J. (1999) Housing policies and the Little Tigers: how do they compare with the other industrialized countries?, Housing Studies, 14(2): 229-50.

Doling, J. (2002) The South East Asian housing policy model, in M.R. Agus, J. Doling, and D.-S. Lee, Housing Policy Systems in South East Asia, London: Macmillan.

Doling, J. and Ford, J. (2003) Globalization and Home Ownership: Experiences in Eight Member States of the European Union, Delft: Delft University Press.

Donnison, D. and Ungerson, C. (1982) Housing Policy, Harmondsworth: Penguin.

Esping-Andersen, G. (1990) The Three Worlds of Welfare Capitalism, Cambridge: Polity Press.

Esping-Andersen, G. (1996) Welfare States in Transition, London: Sage.

Giddens, A. (1991) Modernity and Self Identity: Self and Society in the Late Modern Age, Stanford, CA: Stanford University Press.

Goodman, R. and Peng, I. (1996) The East Asian welfare states: peripatetic learning, adaptive change, and national building, in G. Esping-Andersen (ed.) Welfare States in Transition: National Adaptations in Global Economies, London: Sage.

Henderson, J. and Appelbaum, R.P. (1992) Situating the state in the East Asian development process, in R.P. Appelbaum and J. Henderson (eds) States and Development in the Asia Pacific Rim, Newbury Park, CA: Sage. 
Hirayama, Y. (2003) Housing policy and social inequality in Japan, in M. Izuhara (ed.) Comparing Social Policies: Exploring New Perspectives in Britain and Japan, Bristol: Polity Press, pp. 151-71.

Holliday, I. (2000) Productivist welfare capitalism: social policy in East Asia, Political Studies, 48: 706-23.

Johnson, C.A. (1982) Miti and the Japanese Miracle: The Growth of Industrial Policy, 1925-1975, Tokyo: Charles E. Tuttle.

Jones, C. (1993) The Pacific challenge: Confucian welfare states, in C. Jones, C. (ed.) New Perspectives on the Welfare State in Europe, London: Routledge.

Kemeny, J. (1992) Housing and Social Theory, London: Routledge.

Kemeny, J. (1995) From Public Housing to the Social Market: Rental Policy Strategies in Comparative Perspective, London: Routledge.

Kwon, Huck-ju (1998) Democracy and the politics of social welfare: a comparative analysis of welfare regimes in East Asia, in R. Goodman, G. White and Huck-ju Kwon (eds) The East Asian Welfare Model: Welfare Orientalism and the State, London: Routledge.

Lee, J. (1999) Housing, Home Ownership and Social Change in Hong Kong, Aldershot: Ashgate.

Morishima, M. (1982) Why has Japan Succeeded?, Cambridge: Cambridge University Press.

Rex, J. and Moore, R. (1967) Race, Community and Conflict, Oxford: Oxford University Press.

Schaede, U. and Grimes, W. (2003) Japan's Managed Globalization: Adapting to the Twenty First Century, Armonk, IL: M. E. Sharpe.

Wade, R. (1990) Governing the Market: Economic Theory and the Role of Government in East Asian Industrialisation, Princeton, NJ: Princeton University Press.

White, G. and Goodman, R. (1998) Welfare orientalism and the search for an East Asian welfare model, in R. Goodman, G. White and Huck-ju Kwon (eds) The East Asian Welfare Model: Welfare Orientalism and the State, London: Routledge. 


\section{Glossary}

bakufu military government under shogunate rule

chano-ma Japanese-style dining-living room

danchi multi-family housing estates made up of concrete apartment blocks

danchi-zoku danchi tribe

dankai no sedai post-war baby-boomers

freeter part-time, non-regular workers under 34

fusuma framed and papered sliding doors used to form room partitions

hogo shisetsu shelter and non-monetary aid facilities provided as a form of public assistance

ichioku so churyu popular phrase meaning a social situation where all 100 million of Japan's population (now around 126 million) regarded themselves as members of the middle class

ie family, household, lineage, home, or house

Jiritsu Shien Ho Homelessness (self-help) Act

Jutaku Kinyu Kouko Government Housing Loan Corporation (GHLC)

Jutaku Kinyu Shien Kikou Housing Loan Support Agency (HLSA)

Jutaku Toshi Seibi Koudan Housing and Urban Development Corporation (HUDC)

katei home, family, or household

Kokumin Shinbun The People's Newspaper

Koteki Kaigo Hoken new social insurance scheme

kouei jutaku public rental housing

kyuyo jutaku company housing provided for employees

mai homu my own home

Nihonjinron theories of Japaneseness

Nihon Jutaku Koudan Japan Housing Corporation (JHC)

niwatsuki ikkodate jutaku single-family house with garden

riso no katei ideal home

ryo dormitory-style employee housing provided for singles 
seikatsu hogo public assistance to maintain the minimum living standard Seikatsu Hogo Ho Living Standard Protection Act

shataku company housing provided for employees' families

shogun general (= leader)

shoji sliding paper door

tatami traditional fixed matting

Toshi Kiban Seibi Koudan Urban Development Corporation (UDC)

Toshi Saisei Kikou Urban Renaissance Agency (URA)

uchi and soto inside and outside (socially and spatially). Uchi often used literally to denote the home itself

wayo setchu eclectic style incorporating both Japanese and western elements

yoseba low-income or poor districts characterized by mass flophouses and manual day-labour markets

zaibatsu giant corporate conglomerates 


\section{Index}

affluent society 18,22

ageing in place 105

asset 98; accumulation of 97-8; assetbased public policy 95-7; financial status of older people 98-100; housing (as a source of income) 97, 100-1; asset-rich, income poor $98,105,197$

baby-boomer 10, 30-2, 94-5, 196 back to the city movement 34,38 bad debt problem 51

bakufu 169

bank housing loan 50-1, 53

Benedict, R. 5

Berger, P. 167

Britain see UK

Bramley, G. 142, 144

bubble condominium 38

bubble economy $3,16,23,31,50$ :

economic bubble $6,8,10,23,25,30$, 177,186 ; housing bubble 95 ; postbubble economy 11, 98-100, 185; post-economic bubble 8

capital gain 2, 15-16, 18, 23, 28, 32, 100, 106, 194

capital loss 16, 23, 25-6, 32

capitalism, Japanese 174 , 199, 200, 202

care: for the elderly $119-20$; need for

136; program and children 130-2;

responsibilities 133; social 123; system 126 , see also service

Clammer, J. 167, 182, 201

cold spot 34, 37-8, 40

collective housing 133-4

community: life 120, 136; living 133; sense of 134 compact condominium 36

company housing (kyuyo jutaku or shataku) 76, 79-83, 84-5; rate of 80 , 85

company society $9,20,31,42,198,203$

company welfare system 141

condominium tower 34-7; consumption 179

Confucian welfare state 74

cooperative housing 134

co-residency 102, 110

corporate housing welfare $73,75-7$ : and government 80; and labour unions 81; and 'male breadwinner' paradigm 83 ; as a subsystem of the housing system 79-82; dysfunction of $82-3,89$

corporate sector: as a key of social integration 75,81 ; withdrawal of the corporate sector from housing welfare $84-5,89$

Daiwa House 58, 63

danchi 178, 179; danchi-zoku 179

Daniels, I.M. 180, 188

day labourer 144, 148, 152, 155

demography: ageing of the population 95 , 101; low fertility 101

democratization 175

deregulation 49-50, 65, 68, 70, 106, 108, 187, 199; financial 51

developer 58, 68-9, 71

developmental state 5, 199

Deyo, F.C. 205

Doling, J. 205-6

Donnison, D. and Ungerson, C. 202

dualist rental system/unitary rental market $73,75-6$ 
dwelling form: compartment group dwelling 117; detached house containing independent rooms 118 ; one-room-type accommodations 119-20, see also modern living Dymski, G. 54, 70

East Asian welfare regimes 74, 201-4, 206-7

eclectic style house 173

economic expansion 174, 176

Emergency Redevelopment Zone 65

employee housing 10, 20, 31

England see UK

entitlement 153

Esping-Andersen, G. 73-5, 204

family: life 116 ; nuclear 115,117 ; oneparent and lone-mother 128-9; ties 118-19; the transition of living form from 136; views on the role of 131, see also family norm; household; women

family norm: modern 114-17; patriarchal 117; the sole male breadwinner model 123; standard families 114-15, 123; Japanese 171, 187, see also family; gender

family system 141, 163

feeling of middle-classness $22-3,28$

fertility: declining 3, 8, 16, 29, 32, 196

filtering system $18,20,28-9,31-2$

first-time homebuyer 31-2

Five-Year Housing Construction Plan $39-40,178$

fixed abode $153-5$

fixed-term tenancy 67

freeter 141, 161, 163

gender: disparity by 126; perspective of

117; related barriers 123; related public policy measures 126; relations 123 , 133, 135; role 115, 132; statistics 125-6; urban and housing environment and 123-4, see also family norm; women

general contractor 58, 68-9, 71

globalization 7, 12, 34, 199; global city

34; global competitiveness 8 ; the global diffusion of so-called neo-liberal ideology 39; global economic pressures 6; globalized economic environment 4; globalizing forces 4; global patterns of volatility 6 ; global rules 7 ; the global status of capital 4

Goodman, R. 74; and Peng, I. 74

Goto, M. 75, 81

Government Housing Loan Corporation (GHLC) 15-16, 18, 20, 23-4, 26-7, 31, 49, 50-6, 77, 79, 87; abolishment of 87,187

growth coalition $68-9$

Handler, J. 153, 158, 160

Harvey, D. 140

Haseko Corporation 61

Henderson, J. and Applebaum, R.P. 199

Hendry, J. 172

Holliday, I. 204

Homeless Independent Living Act, Homeless Independent Policy 152, 156; homeless people $144-5,148,153-6$, 158-9, 160-3; homeless policy 144 , 152, 163; homeless population 144, 154 homelessness $140-5,147-8,150,152-3$, $155,159,161-3,197$

homeowner society $18,20-1,27-8,31$

hot spot 34, 38, 40

house-builder 58, 69; design 173; prefabricating house-builder 59,61 ; small house-builder 58-9, 64-5 household: age of householders 120; diversity in 124; female- and maleheaded 126-7; non-conventional and conventional 117-9; one-person 118, $122,126-8$; size of $118,120,122$, see also family; housing conditions housing affordability $68-9$ housing allowance 78, 90, 154, 159-60; lack of 78, 90

Housing and Urban Development Corporation (HUDC) 16, 49, 86-7

housing asset see asset

housing benefit or allowance 123, 129, 132,135

housing conditions: and household types $120-3$; minimum housing standards 122 , see also household

housing construction 47, 56-7, 62-3, 196 Housing Construction Plan Act 67 housing expenditure: among one-person households 127; women-headed household and 128-9

Housing Finance Agency 16, 49

housing ladder $8,18,20-1,23,28,30-1$, $39,42,176,177,183,186$ 
housing poverty 21,40

housing tenure $3,17,28,31$ : disparities in 121; distribution of 129 , see also owner-occupied; rental

human capital 145, 152, 159, 161

ie $166,168-9,171,175,177,179,180$, $182,186-7,188$

ideal home 173

Imada, T. 22

inclusion 143-4, 149, 151, 155-6, 158-63;

policy $141,156,158-9,161,163$;

inclusion-through-housing 160, 162-3;

inclusion-through-work 148, 155-6, $158,160-3$

inclusive society 97

industry-wide labour union: lack of 81

inequality: social $5,11,21,23,28-9,33$, 91, 96-7, 103, 111, 183-4, 197, 201, 208; wealth 99

inheritance 100, 102, 107; housing 32-3; inheritance tax 104; intergenerational asset transfer 101-3, 109

institutional living: communal facilities 130; for lone mother families (Life

Support Center for Mother and Children) 129-31

international comparison: of housing tenure 77; of social housing 78

Izuhara, M. 97, 102-3, 109

Japan Business Federation 66

Japanese Bankers Association 52-3

Japan Federation of Housing Organizations 66

Japan Housing Corporation (JHC) 15-16, 18, 49, 77, 86-7; reorganization of 86

Japanese dream 176

job-associated housing (job associated accommodation) 148-9, 151-2

Johnson, C. 5, 199

Jones, C. 74, 200

katei 169, 170, 173, 188

Kemeny, J. 73, 75-6, 166, 203

Kishimoto, S. 22

Levitas, R. 142

Liberal Democratic Party (LDP) 2-3, 87, 195, 206, 195

life-estate 109 lifestyle: communal life 133-4; diversity of 114, 135-6; housing conditions and 120 ; individualization of living unit and 117-19; preference 131-2, see also family norm; gender; women

Living Standard Protection Act 152-6, 162-3

long-term care 97; social insurance scheme for long-term care 102-3

long-term employment 141

long-term excluded 149, 150-2

Lost Decade, The 3, 165, 195, 197

mainstream of society 42 ; middle-class $174,176,177,179,181,183$

market-oriented housing policy $85-90$; marketization 187, 199, 200

Martens, M. 70

mega-bank 51-2

Meiji era 167, 168, 173

metropolitan area 62

middle-class, society 15-17, 21, 28, 42, 194,197 ; identity 175,181 ; stability 176; values 173

mini-housing development 57-8

Miyake, J. 17, 20, 24, 30

modern living: image of 115; Japanese modern living 118; 'n-DK' and 'nLDK' 115-17; principle 130, see also dwelling form

modernity $167,175,186$

modernization 170, 176, 180

mortgage-backed security $16,54-5$

mortgage reverse 105-6

Moving to Community Policy 159 , 162-3

Murakami, Y. 22

Nakane, C. 5

NEET 141, 161

negative demand 24, 31

negative equity problem 52

neo-liberal 8; ideology 39; neo-liberalism

7, 50, 200; reform politics and housing policy 87,90

Nihonjinron 171

Osawa, M. 73, 83

Ozaki, R. 183

Percy-Smith, J. 142

positive demand 24, 31 
poverty $141-4,154-5,158,162$

privacy: communal life and 134; demand for 119; in family life 116, 178; sensitivity to 118 , see also community; family norm and lifestyle

public assistance 97, 103

public housing 15-18, 41, 77; residualization of $86,88,90$

\section{Rapoport, A. 181}

rent act: liberalization of 88

rental: and lone mother families 128-9; rent level 123; unit size and opinions of dwellers 121-2, see also housing tenure Rent Regulation Ordinance 17 risk 42, 104, 201; credit 52; prepayment 52

safety net $41,88,90,163,203$

saving 98-9, 104

scrap and build 9, 57-58, 61, 65, 67, 69-70, 95, 110, 179, 196

Schaede, U. and Grimes, W. 199-200

secondary residential property 33

second-hand housing 25-6

self-help 78; as the principle of Japan's post-war housing policy 78

service: caring 132; collective 133; for childcare 129-30; housing related 115, 135-6; lifestyle and 118; on-site 130-1, see also care

shared housing 134, 136

single women 36

Small Office Home Office (SOHO) 36

social (societal) ageing 8, 10, 29, 196

social assistance (public assistance) $155-8$, 162-3

social class 182,184

social contract 103

social divide 90,196

social exclusion $140-5,152,162-3$

social fragmentation 3-4, 12, 196, 199

social housing 123, 126, 129, 135

social mainstream 4, 8, 15, 28, 174, 176-9, 181,183

social status 170,173

socialization of care 103

socio-physical space 144

sozialer Wohnungsbau 78

standard household 15-16, 29, 35, 197

standard life-course 15-16, 29

step repayment system 23 strategies of liquidising housing assets: inter-vivo transfer 110; purpose-built housing 108-9; renting out additional properties 106-7; reverse mortgages also see mortgage; trading down 107-8 street homelessness 141, 144-5, 152, 155, 163

suburban bubble condominium 38

Sugimoto, Y 184

super-luxury condominium 38

tatami 178,180

Tiger economies 201-4, 206-7

three pillars of Japan's post-war housing policy $15-16,18,39,77,85$

tower-type condominium see condominium tower

UK 95, 97, 105-6, 111, 118, 120, 122, 126, 141, 174, 177, 207

uchi and soto 172, 181-2

ultra-distant suburb 38-9

unemployment 140-1, 144-5, 151-2, 161

Urban Development Corporation (UDC) $16,49,87,187$,

urbanization $8,11,18,24,34$

urban renaissance 34, 38, 186, 187

Urban Renaissance Agency (URA) 16, 49,87

vertical enclave 35

Vertical Society 5

Wade, R. 2004

Watsuji, T. 172

welfare categories 41

welfare gap: between corporations of different sizes 82 ; between regular and non-regular employees 82-3

welfare office 162

welfare regime theory 73 ; and corporate sector 73, 75; and the Japanese housing system $73-5,185$

welfare state 2 ; integration 81 ; strategies 206

Wohngeld 78

women: alternative residential forms for 133-4; conditions of living alone 126-8; disparities in situations 124-6; diversification of roles for 114; diversity in types of households 124; employed 124-6, 132-3; life chance 
Index

of $124,126,132$, 135; with children 131-3, see also gender; lone-mother families

work requirement 153 yoseba $144,152,155$

young cohort 29

zaibatsu 175 
eBooks - at www.eBookstore.tandf.co.uk

\section{A library at your fingertips!}

eBooks are electronic versions of printed books. You can store them on your PC/laptop or browse them online.

They have advantages for anyone needing rapid access to a wide variety of published, copyright information.

eBooks can help your research by enabling you to bookmark chapters, annotate text and use instant searches to find specific words or phrases. Several eBook files would fit on even a small laptop or PDA.

NEW: Save money by eSubscribing: cheap, online access to any eBook for as long as you need it.

\section{Annual subscription packages}

We now offer special low-cost bulk subscriptions to packages of eBooks in certain subject areas. These are available to libraries or to individuals.

For more information please contact webmaster.ebooks@tandf.co.uk

We're continually developing the eBook concept, so keep up to date by visiting the website. 


